


\section{Education Systems Around the World}

Edited by Gilson Porto Jr. 

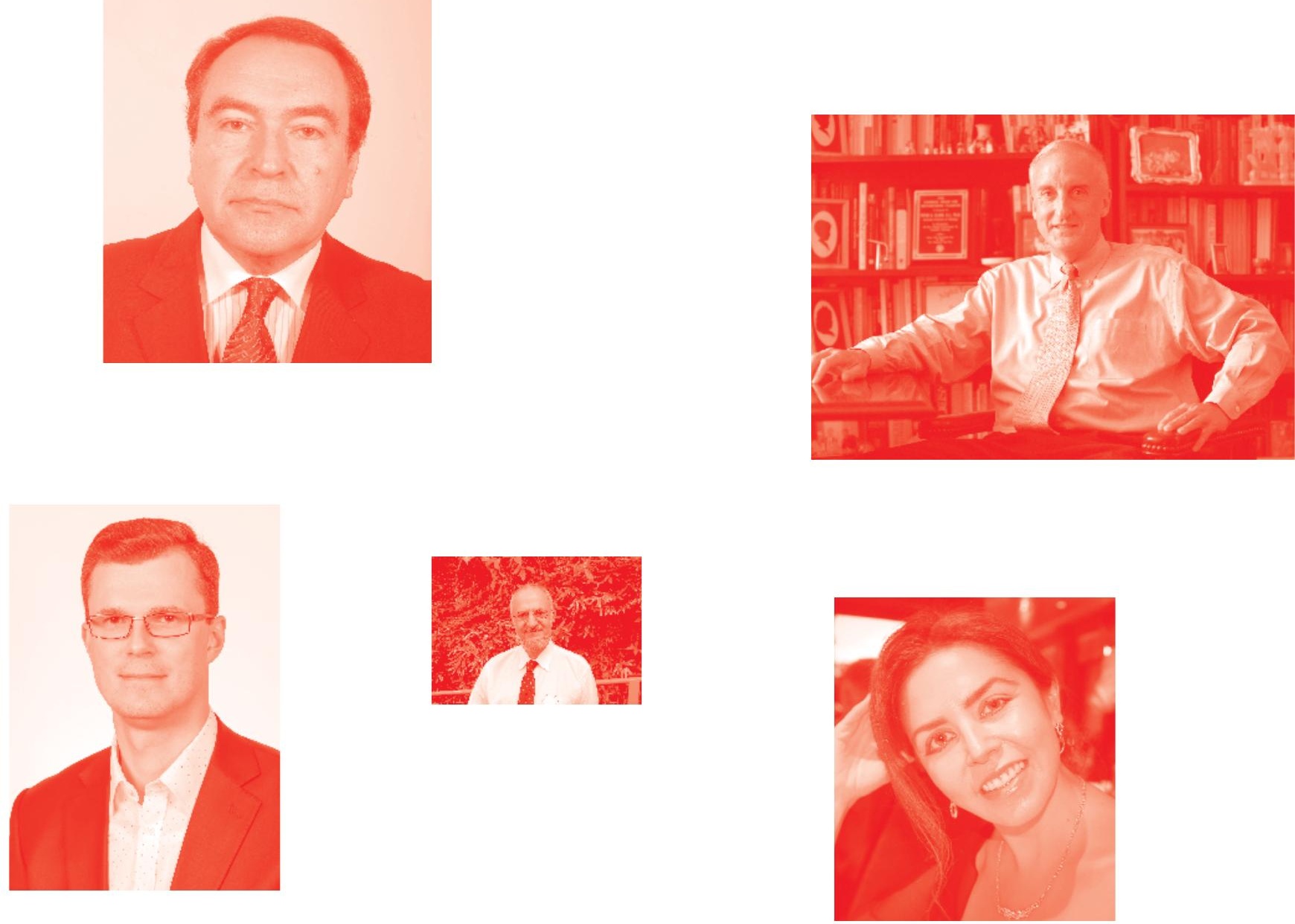

Supporting open minds since 2005
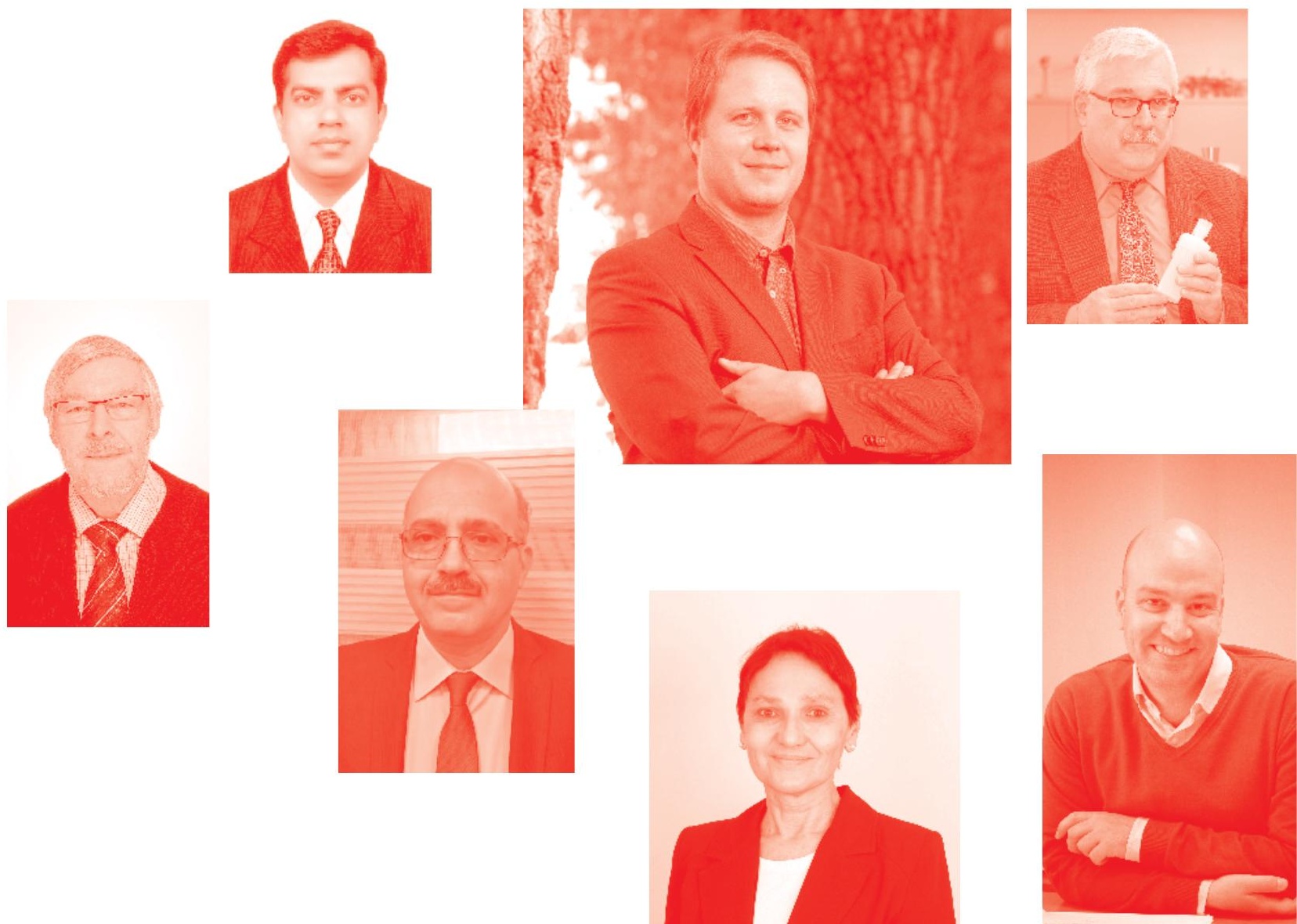
Education Systems Around the World

http : //dx. doi.org/10.5772/intechopen. 77636

Edited by Gilson Porto Jr .

Contributors

Lee Waller, Sharon Waller, Kehdinga George Fomunyam, N'da Koffi Koffi Christan, Domingos João Fernandes, Maria Sotolongo Sánchez, Rashad Kurbanov, Ramin Gurbanov, Asiya Belyalova, Zingiswa Jojo, Guillermo Molero-Castillo, Everardo Bárcenas, Alejandro Velázquez-Mena, Yaimara CéspedesGonzález, Ephraim Taurai Gwaravanda, Ramzi Nasser, Gilson Porto, Sona Armena Balasanyan, Franco Blezza

( ) The Editor(s) and the Author(s) 2020

The rights of the editor(s) and the author(s) have been asserted in accordance with the Copyright, Designs and Patents Act 1988. All rights to the book as a whole are reserved by INTECHOPEN LIMITED. The book as a whole (compilation) cannot be reproduced, distributed or used for commercial or non-commercial purposes without INTECHOPEN LIMITED's written permission. Enquiries concerning the use of the book should be directed to INTECHOPEN LIMITED rights and permissions department (permissions@intechopen.com).

Violations are liable to prosecution under the governing Copyright Law .

\section{(cc) BY}

Individual chapters of this publication are distributed under the terms of the Creative Commons Attribution 3.๑ Unported License which permits commercial use, distribution and reproduction of the individual chapters, provided the original author(s) and source publication are appropriately acknowledged. If so indicated, certain images may not be included under the Creative Commons license. In such cases users will need to obtain permission from the license holder to reproduce the material. More details and guidelines concerning content reuse and adaptation can be found at http : //www . intechopen . com/copyright-policy . html .

\section{Notice}

Statements and opinions expressed in the chapters are these of the individual contributors and not necessarily those of the editors or publisher. No responsibility is accepted for the accuracy of information contained in the published chapters. The publisher assumes no responsibility for any damage or injury to persons or property arising out of the use of any materials, instructions, methods or ideas contained in the book.

First published in London, United Kingdom, 2020 by IntechOpen IntechOpen is the global imprint of INTECHOPEN LIMITED, registered in England and Wales, registration number: 11086078 , 7th floor, 10 Lower Thames Street, London,

EC3R 6AF, United Kingdom

Printed in Croatia

British Library Cataloguing-in-Publication Data

A catalogue record for this book is available from the British Library

Additional hard and PDF copies can be obtained from orders@intechopen.com

Education Systems Around the World

Edited by Gilson Porto Jr.

p. $\mathrm{cm}$.

Print ISBN 978-1-78984-391-0

Online ISBN 978-1-78984-392-7

eBook (PDF) ISBN 978-1-83880-๑81-9 


\section{We are IntechOpen, \\ the world's leading publisher of Open Access books}

Built by scientists, for scientists

\section{$4,700+$}

Open access books available

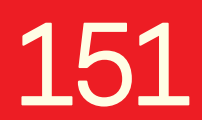

Countries delivered to

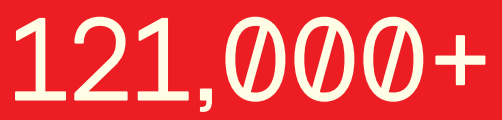

International authors and editors

Our authors are among the

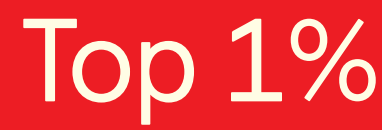

most cited scientists

Contributors from top 500 universities
40010

Downloads

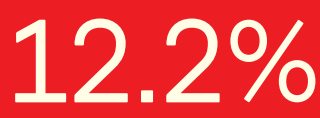

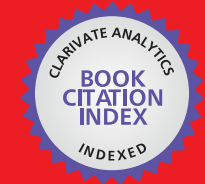

WEB OF SCIENCE ${ }^{\text {MM }}$

Selection of our books indexed in the Book Citation Index in Web of Science ${ }^{\mathrm{TM}}$ Core Collection (BKCI)

Interested in publishing with us?

Contact book.department@intechopen.com

Numbers displayed above are based on latest data collected.

For more information visit www.intechopen.com

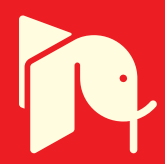





\section{Meet the editor}

Gilson Porto Jr. holds a PhD in Communication and Contemporary Culture from the Communication Faculty of the Federal University of Bahia (UFBA), a Master in Education from the School of Education (UnB), and in Social Communication/Journalism, Pedagogy, and History. He holds a postdoctoral degree in Education and Technologies from the University of Cadiz (UCA, Spain), in Education from the University of Coimbra (UC-CEIS20, Portugal), in Journalism and Society from the Postgraduate Program in Communication (FAC-UnB) and Applied Social Sciences, State University of São Paulo Júlio de Mesquita Filho (UNESP). He is currently a Professor at the Federal University of Tocantins (UFT, Brazil). 



\section{Contents}

Preface

Section 1

Introducing the Debates

Chapter 1

Introductory Chapter: Communication, Education, and

Internationalization - Paths and Possibilities of the Systems in the

European Union

by Francisco Gilson Rebouças Porto Junior

\section{Section 2}

Studies and Researches

Chapter 2

Evaluation of Human Capital as a Contribution to the Performance of the José Eduardo dos Santos University-Republic of Angola

by Domingos João Fernandes and María Sotolongo Sánchez

Chapter 3

Education Systems in Eurasia

by Rashad Kurbanov, Ramin Gurbanov and Asiya Belyalova

Chapter 4

Full Funnel International Enrollment Management

by Lee Waller and Sharon Waller

Chapter 5

Lessons from the History of Pedagogical Methods for Culturally

Responsive Teaching and Learning

by Sona Balasanyan

Chapter 6

Students and Institutional Preparedness for Educational Encounters:

Views of the Margin

by Kehdinga George Fomunyam

Chapter 7

Educational Reform in Oman: System and Structural Changes

by Ramzi Nasser 
Chapter 8

Analysis of Academic Achievement in Higher-Middle Education in

Mexico through Data Clustering Methods

by Guillermo Molero-Castillo, Everardo Bárcenas,

Alejandro Velázquez-Mena and Yaimara Céspedes-González

Chapter 9

Discrete Choice Model: An Application to the Educational Decision of Ivorian Households

by N'da Koffi Christan

Chapter 10

Mathematics Education System in South Africa

by Zingiswa Jojo

Chapter 11

An Epistemological Critique of the African University Education System by Ephraim Taurai Gwaravanda

Chapter 12

Pedagogist as Social Professional: Sozialpädagogik and Professional

Pedagogy

by Franco Blezza 


\section{Preface}

This book - Education Systems Around the World - is composed of two sections: the first, entitled "Introducing the Debates" is the introductory text by Dr Francisco Gilson Rebouças Porto Junior (OPAJE-Federal University of Tocantins-UFT, Brazil), entitled "Communication, education and internationalization: paths and possibilities of the systems in the European Union". The author reflects on the education system in the European Union, post-Bologna process, and the impacts of globalization, focusing on internationalization and mobility in the European bloc.

In the second section, "Studies and Research", eleven chapters are shared with different emphases, but all provide an important theoretical contribution around the book's theme. Despite the varied approaches, formats, and research, all the chapters are the result of the intellectual exercise of reflecting on public policies, systems, and training in various parts of the world.

The first chapter, "Evaluation of Human Capital as a Contribution of the Performance of the José Eduardo dos Santos University - Republic of Angola”, is written by Dr Domingos João Fernandes (José Edaurdo dos Santos University, Angola) and Dr María Sotolongo Sanchez (Marta Abreu Central University of Las Villas, Cuba). The authors discuss the social responsibility of the university in ensuring the quality of education offered. The focus is on teaching skills and teachers' performance in their university activities.

The second chapter, "Education Systems in Eurasia”, is by Dr Rashad (Institute of Legislation and Comparative Law under the Government of the Russian Federation, Russia) Kurbanov, Dr Ramin Gurbanov (Plekhanov Russian University of Economics, Russia), and Dr Asiya Belyalova (Institute of Legislation and Comparative Law under the Government of the Russian Federation, Russia). In the chapter, the authors focus on national-level education systems in the Eurasian states and their unification within a framework of international regional organizations. Highlights of the chapter are the elements of the educational system and the links between them, for example; state agencies and other state entities that regulate educational relations; and innovation policies in education in all states - universities and networks digital technologies.

The third chapter, "Full Funnel International Enrollment Management", is by Dr Lee Waller (American University of Ras Al Khaimah, United Arab Emirates) and Dr Sharon Waller (American University of Ras Al Khaimah, United Arab Emirates). The focus of the chapter is the process of recruiting new students and the strategies used for the dissemination, enrollment, orientation, and participation of foreign students in academic mobility.

The fourth chapter, "Lessons from the History of Pedagogical Methods for Culturally Responsive Teaching and Learning”, is by Dr Sona Balasanyan (Yerevan State University, Armenia). The chapter presents and discusses educational practices based on examples from the history of pedagogical methods in classical to postmodern realities. Visa derive lessons by exploring global social contexts 
of teaching and learn to address diversity and multiculturalism in contemporary education.

The fifth chapter, "Students and Institutional Preparedness for Educational Encounters: Views and the Margin", is by Dr Kehdinga George Fomunyam (Teaching and Learning Development Center, Mangosuthu University of Technology, Durban, South Africa). In the chapter, the author focuses on the challenges that higher education faces in South Africa for national and international academic mobility within the African continent.

The sixth chapter, "Educational Reform in Oman: Systems and Structural Changes", is by Dr Ramzi Nasser (University of Sharjah, Sharjah, United Arab Emirates). The chapter presents a historical perspective of the educational developments of the Sultanate of Oman, as well as the systemic and structural changes required for the educational organization aligned with international standards.

The seventh chapter, "Analysis of Academic Achievement in Higher-Middle Education in Mexico through Data Clustering Methods", is written by Dr Guillermo Molero-Castillo (Engineering Faculty, National Autonomous University of Mexico, Mexico), Dr Everardo Bárcenas (Engineering Faculty, National Autonomous University of Mexico, Mexico), Dr Alejandro Velázquez-Mena (Engineering Faculty, National Autonomous University of Mexico, Mexico), and Dr Yaimara CéspedesGonzález (University of Veracruz, Mexico). The authors discuss new ways to analyze the academic performance of students in autonomous, public, and private high schools in Mexico, using data analysis methods. This study broadens the understanding of the need for competencies and skills for future college graduates.

The eighth chapter, "Discrete Choice Model: An Application to the Educational Decision of Ivorian Households", is written by Dr N'da Koffi Christan (Jean Larougnon Guédé University, Daloa, Côte d'Ivoire). In the chapter, the author highlights the use of a model applied to the decision process, used in research applied between 1998 and 2008, focusing on school education and the possible impacts that may have on higher education.

The ninth chapter, "Mathematics Education Systems in South Africa", is written by Dr Zingiswa Jojo (University of South Africa (UNISA), Pretoria, South Africa). In the chapter, the author deals with the teaching of mathematics in schools in South Africa. The focus of the chapter is on reparations in the math curriculum and changes in the post-apartheid era, the exploration of mathematics education, democracy, and development, along with the introduction of mathematical literacy as an alternative compulsory subject for students as a way to overcome deficiencies in training.

The tenth chapter, "An Epistemological Critique of the African University Education Systems", is written by Dr Ephraim Taurai Gwaravanda (Department of Philosophy and Religious Studies, Great Zimbabwe University, Masvingo, Zimbabwe). The author discusses the African university education system that is characterized by the domination of the Eurocentric epistemological paradigm due to factors such as colonialism, imperialism, and globalization. The author proposes an African epistemological paradigm for the educational system.

Finally, the eleventh chapter, "Pedagogist as Social Professional: Sozialpädagogik and Professional Pedagogist", is written by Dr Franco Blezza, (full professor 
on General and Social Pedagogy, DPPEQS, Università degli Studi “Gabriele d'Annunzio", Chieti- Pescara, Italy). This chapter summarizes the essential characteristics of the pedagogist profession, his methodology, his principles, his practical procedures, with special attention to the problems of the couple and family, and those pertaining to his early education and recognition by laws that in Italy were resolved only at the end of 2017.

We are sure that reading and reflecting on the chapters presented will add value to the debate on education and global education systems.

Dr Gilson Porto Jr. OPAJE-Federal University of Tocantins-UFT, Brazil 

Section 1

\section{Introducing the Debates}





\title{
Introductory Chapter:
}

Communication, Education, and Internationalization - Paths and Possibilities of the Systems in the European Union

\author{
Francisco Gilson Rebouças Porto Junior
}

\section{Introduction}

The crisis in the European Union was a scenario announced long ago. Authors point a series of situations that indicated the construction of a structural crisis in the European continent: the globalization of economy under the influence of large economic spaces; the limits of market economy and the failure in the compatibility between growth and solidarity; the intense outsourcing that changed the productive network from a goods economy to a service economy; the shortage of workplaces, even with the existent cycles of hiring and expansion; the fast change in the nature and content of occupational structure; the decrease of private and public savings, with consumerism reinforcement; the transnational flow of capitals; and the collapse of leadership behavioral values [1-16].

In this environment surrounded by the possibilities of a structural crisis, the consolidation of the European Union and its yearnings for mobility and employability and the strengthening of transnational economies found a possible answer in the search for a common education, with accreditation and validation in partner countries [17]. It is the search for formative educational process internationalization. This word has gradually replaced the concept of globalization in education, being more accepted in formative spaces.

\section{Communication, education, and internationalization}

The concepts around internationalization are diverse, and they represent different understanding perspectives of the social and formative space. These concepts are permeated by individual, collective, and block interests that tend to strengthen certain visions of the world and society.

In the academic field, a place of dispute and contradiction, these visions about what is the internationalization of higher education and its impacts are, very often, focus of problematization and lively discussions. Therefore, it is important to understand that the discussion around the internationalization of higher education occurs inside the discussion of the own concept of globalization. In the last years of the twentieth century, in educational scope, 
the word globalization was being gradually replaced by the idea of internationalization, since the first notion is seen in the formative space as negative and conflicting [18].

Giddens 1990, p. 64 apud [19] defines globalization as the "[...] intensification of world social relations that bond distant locations in such a way that the local events are conditioned by events that happened many miles and vice versa" (free translation). Albrow [20] goes beyond and says that globalization is "[...] the process by which the population of the world became increasingly unite in a single society" (free translation). But whoever thinks that it is only financial is wrong. Giddens himself [21] affirms that the "[...] globalization is political, technological, and cultural, as much as financial" (free translation), influenced by communication systems. It can be noticed when thinking about the Bologna Process [1].

Indeed, technology and communication have facilitated the dissemination and the exchanges among countries instantly, expanding the perception that "the distant world is closer than we think" (free translation) and the feeling that it is possible to touch it and change it. Giddens [21] reinforce that feeling the world, without obstacles and widely, ended the "age of nation-state," with its determined obstacles. This seems to be here the main problem when discussing about the word globalization. It seems to be, in the ordinary mind, mediated by the mass media, synonym of free market, end of trade barriers, reduction of social spending, and end of social security, just to indicate some of the related subjects mentioned as the "social apocalypse" caused by the globalizing neoliberal vision.

Giddens [21] reinforce that "[...] globalization is not, therefore, a singular process, but a complex set of processes" (free translation). This perspective is important, as the notion of globalization is associated with the idea of loss, withdrawn. When thinking about Bologna, this was one of the feelings the participants of formative educational activities had about the whole process [17, 22-25], and this was also noticed in the social communication/journalism area. Indeed, losses occur, because deep curricular and formative changes were established, but there are also possible gains with the interrelationships with other countries, among them the resurgence of cultural identities, previously fragmented and forgotten by national societies, and "new economic and cultural areas inside e through nations" [21].

Santos [19] remembers "globalization results, indeed, from a series of political decisions identified in time and in authorship," since it "[...] disorganized the hierarchies of the previous global economy" (free translation). This recognition of "time and authorship" reinforces that the epistemological breach caused by globalization had an important moment, time, and space in the disorganization of systems and crystallized hierarchies, but it does not mean, necessarily, that it could not be resignified [19].

This resignification has been made and in the educational field gradually slowed down the notion of globalization by using the expression internationalization. Less rejected by the wider community, the expression tries to agglutinate resignified elements of globalization, producing similar effects, as in the case of regionalization [26-28]. Internationalization, apparently less threatening than globalization, is defined as the expression of postures and actions updating, and it is already practiced in the foundations of university. Therefore, the impact is mitigating, but not the necessary actions to consolidate the formative processes necessary to the Bologna implementation. 
Introductory Chapter: Communication, Education, and Internationalization - Paths... DOI: $h$ ttp://dx.doi.org/10.5772/intechopen.87106

Morosini [29] says that:

The internationalization of higher education (Ides) is considered as any systematic effort that aims to make higher education more responsive to the demands and challenges related to the globalization of society, economy, and job market. (Free translation)

This response action to the challenges and demands of society is also shared by other authors. Knight [30] affirms that internationalization has as its focus on "[...] the process of integrating and international or intercultural dimension into the research, teaching and services functions of an institution of higher education." More pragmatist, Knight [30] understands the interaction in an international scope focusing in the university pillars. Really close to the opinion of Morosini [29], Wende [31] reinforces that the internationalization of higher education includes “[...] any systematic, sustained effort aimed at making higher education (more) responsive to the requirements and challenges related to the globalisation of societies, economy and labour markets." These indications, despite having their focuses on Brazil and North America, are applied worldwide.

\section{Paths and possibilities}

In the Portuguese space, these perspectives are also shared to a greater or lesser extent. With Bologna, Portugal awakened to education and learning as fundamental parts in the knowledge economy. About this perspective, Reis and Camacho [32] indicate that:
Politically, this process also fits in the strategic option that the European Union made, in 2000, to become until 2010, in the most competitive and dynamic knowledge economy of the world, capable of a lasting economic growth, anchored in a sustainable economic progress, with environmental concern, followed by a quantitative and qualitative improvement of employment and social cohesion (Lisbon Strategy). The concept of knowledge economy fits in the scope of knowledge society and assumes a strong bet in the increase of the levels of human resources skills, namely through a lifelong learning process, and in the scientific and techno- logical development. (Free translation)

Mobility—from students, professors, and technicians—reinforced by the Bologna speech, allowed this knowledge economy to be shared among nations. Formation and investigation networks were created and tuned, resulting in more fluidity of knowledge, which is close to what Castells [18] calls informational economy. In addition, the curriculum realignment, not fully creating common contents but approaching common professional competencies and skills, allowed students, professors, and technicians to be inserted in realities that were totally different from what they experienced in their home countries [33]. It is on this path that the Bologna proposal eased the interaction and the exchange of expertise among countries, even if not totally set and operational $[14,16,34,35]$.

Internationalization, reinforced and amplified by the Bologna speech, allowed the modernization and the debureaucratization of university structures, which resulted in more attractiveness and visibility [13-16]. Giddens [21] certifies this, indicating that "[...] new economic and cultural zones inside and through nations" 
(free translation) are created and reinforced. But we cannot fail to realize that, as universities open to a new market, more "technological and technocratic," new demands as "[...] efficiency, productivity, competitiveness, profitability, costbenefit analysis, result evaluation, results-based management" (free translation), never considered before with emphasis in public institutions and in the "doing" of professors ${ }^{1}$, are reinforced and put in the center of the formative educational speeches [33].

This new technical-educational-formative vocabulary, mixed with technological elements, consists in a new paradigm of formation, which has teaching as its focus. Formative processes were resignified, creating the perspective of the constitution of a new society composed by competent citizens for a transnational community that has its curricula denationalized ${ }^{2}$, focused on the continent's future $[36,37]$.

\footnotetext{
${ }^{1}$ About these changes, Josep M. Blanch, professor of the Universitat Autònoma de Barcelona (UAB), in an interview for Bianchetti [33], highlighted the impacts of Bologna on the teaching work in his institution: "But changing from an 'old' system, based on teaching, masterful, from an university more similar to the German and French type, universal, encyclopedic, with many contents, to a model similar to the AngloSaxon, where the reference center becomes the student and not the professors is something complex. ECTS credits are no longer counted in the professor-hour system (basic reference of the system based on the professor's 'teaching'), but in student-hour system (rhetorical reference of the system based on the student's 'learning'). An old credit meant 10 professor-hours, more or less. Now, a new credit becomes 25 student-hours, which depending on the subjects, might be seven professor-hours, ten hours of fieldwork and eight hours in the library depending on the subject or content, if it is more theoretical, practical or experimental. Therefore, this is a change of concept. [...] about this I calculate that the transition from the modern system to the post-modern, from the old system to Bologna system, I assume - talking about my work field - a $30 \%$ work increase, at least, which clearly should imply $30 \%$ more in means, human, technical, and material resources, not to mention the difference between the linear and diachronic time of the 'thesis that traveled by boat' in the 1980s and the synchronic and instant time of the archive that 'travels' through internet" (free translation).

2 The project TUNING Educational Structures in Europe, which began in May 2001, had as its aim obtaining a degree of convergence in the European Union and in the higher education systems in the block countries. Five major areas were the focus: mathematics, geology, management, history, and education science. The program's aim was to define professionally accepted parameters in these major areas.
} 
Introductory Chapter: Communication, Education, and Internationalization - Paths...

DOI: http://dx.doi.org/10.5772/intechopen.87106

\section{Author details}

Francisco Gilson Rebouças Porto Junior

Universidade Federal do Tocantins (UFT), Palmas, Tocantins, Brazil

*Address all correspondence to: gilsonporto@uft.edu.br

\section{IntechOpen}

(C) 2020 The Author(s). Licensee IntechOpen. This chapter is distributed under the terms of the Creative Commons Attribution License (http://creativecommons.org/licenses/ by/3.0), which permits unrestricted use, distribution, and reproduction in any medium, provided the original work is properly cited. (cc) BY 


\section{References}

[1] Fernandes SVA. O princípio da subsidiariedade nas políticas de ensino superior da União Europeia [Dissertação (Mestrado em Ciência Política e Relações Internacionais)] Lisboa: Universidade Nova de Lisboa/Faculdade de Ciências Sociais e Humanas; 2012. p. 93

[2] Costa JMBP. Europa-Política comum de segurança e defesa ou potência civil?: O contributo do processo europeu para a "governança" global [Tese (Doutorado em Relações Internacionais)]. Lisboa: Universidade Nova de Lisboa; 2011. p. 355

[3] Cortez JT. O papel do federalismo como fonte da construção europeia [Dissertação (Mestrado em Ciência Política e Relações Internacionais)]. Lisboa: Universidade Nova de Lisboa; 2010. p. 189

[4] Pereira FMA. A Europa nos media: Estudo de caso sobre a europeização da esfera pública portuguesa. [Dissertação (Mestrado em Ciência Política e Relações Internacionais)]. Lisboa: Universidade Nova de Lisboa; 2010. p. 122

[5] Wielewicki, Hamilton de G; Oliveira, Marlize R. Internacionalização da Educação Superior: Processo de Bolonha. Revista Ensaio-Avaliação, Políticas Públicas e Educação, Rio de Janeiro, v. 18, n. 67, p. 215-234, 2010

[6] Paulos MR. Tendências futuras de evolução das qualificações na Europa. IET Working Papers Series No. WPS01/2008. Lisboa; 2008. pp. 1-16

[7] Hameline D. Os Professores: Prisioneiros, Cúmplices? Que Nova Profissionalidade? Porto: Edições ASA; 2000. Disponível em: http://www. cursoverao.pt [Acesso em: 01 June 2017]

[8] Terrén E. A Educação Face aos Desafios da Pós-modernidade. Porto: Edições ASA; 2000. Disponível em: http://www.cursoverao.pt [Acesso em: 01 June 2017]

[9] Stavenhagen R. O Tesouro da Educação: Uma Velha Arca Apta Para Enfrentar o Século XXI? Porto: Edições ASA; 1996. Disponível em: http://www. cursoverao.pt [Acesso em: 01 Maio 2017]

[10] Carneiro R. A Evolução da Economia e do Emprego: Novos Desafios Para os Sistemas Educativos no Dealbar do Século XXI. Porto: Edições ASA; 1995. Disponível em: http://www. cursoverao.pt/c_1995/RCar-01.html [Acesso em: 01 March 2019]

[11] Pires ALO. Desenvolvimento pessoal e profissional: Um estudo dos contextos e processos de formação das novas competências profissionais [Dissertação (Mestrado em Ciências da Educação)]. Lisboa: Universidade Nova de Lisboa; 1995. 219p

[12] Lema Paula B, Teixeira

José A. Desindustrialização.

Reindustrialização. Terceirização.

Lisboa: Revista da Faculdade de Ciências Sociais e Humanas; 1988. pp. 75-88

[13] Pôrto Junior FGR. Entre Comunicação e Educação: o Processo de Bolonha e as ações formativas em cursos de Comunicação Social/ Jornalismo em Portugal [Tese (Doutorado em Comunicação e Culturas Contemporâneas)]. Salvador: UFBA/ Faculdade de Comunicação; 2012. 614p

[14] Pôrto Junior FGR. Novas geografias curriculares na União Europeia: O processo de Bolonha e a formação em Comunicação Social/ Jornalismo. Revista Interin Curitiba. 2014;17(1):11-95

[15] Pôrto Junior FGR. Processo de Bolonha: História, Formação e Ensino na União Europeia. Porto Alegre, RS: Editora Fi 2014; 2017 
[16] Porto Junior FGR, Moraes N. Formando Pesquisadores Pós-bolonha em Portugal: relações entre a formação de graduação e o campo da pesquisa/ investigação. Revista Observatório. 2017;3(6):202-228. DOI: 10.20873/ uft.2447-4266.2017v3n6p202

[17] Fernandes P, Mouraz A, Sampaio $M$. Tendências da formação contínua de professores da Universidade do Porto em período pós-Bolonha: Uma análise focada nos discursos "oficiais." Repositório Aberto da Universidade do Porto. Porto: Universidade do Porto; 2012. pp. 5048-5065

[18] Castells M. A Sociedade Em Rede. São Paulo: Paz e Terra; 2000

[19] Santos B d S, editor. Globalização: Fatalidade ou Utopia. Porto: Edições Afrontamento; 2001

[20] Albrow M. Globalização. In: Outhwaite W, Bottomore T, editors. Dicionário do Pensamento Social do Século XX. Rio de Janeiro: Jorge Zahar Editor; 1993. pp. 340-341

[21] Giddens A. Mundo em Descontrole: O que a Globalização está Fazendo de nós. Rio de Janeiro: Record; 2003

[22] Fernandes P. O Processo de Bolonha no seu terceiro ano de existência: Olhares diversos para um debate útil. In: Revista Educação, Sociedade e Culturas. Vol. 28. Porto: Universidade do Porto/Centro de Investigação e Intervenção Educativas (CIIE); 2009. pp. 161-173

[23] Fonseca A et al. Análise de Uma Estratégia Universitária na Adaptação aos Requisitos de Bolonha. Vol. 6. Porto: Revista da Faculdade de Ciências Humanas e Sociais; 2006. pp. 232-248

[24] Morgado JC. Processo de Bolonha e ensino superior num mundo globalizado. Educação e Sociedade. 2009;30(106):37-62
[25] Roberto J, Saraiva M, Casas

Novas J. Ensino Superior em Portugal: Transpondo Fronteiras à luz do Novo Paradigma de Bolonha? Portugal: Universidade de Évora; 2007. pp. 1-20

[26] Zgaga P. Ten years after: time for reconsideration. In: Processing the Bologna Process: Current Losses and Future Gains; Zagreb: University of Zagreb/UNESCO; 5-6 March, 2010. pp. $1-30$

[27] Zha Q. Diversification or homogenization in higher education: A global Allomorphism perspective. Higher Education in Europe. 2009;XXXIV(3-4):459-480

[28] Zorrinho C. Ordem, Caos e Utopia: Contributos Para a História do Século XXI. Lisboa: Editorial Presença; 2001

[29] Morosini MC. Estado do conhecimento sobre internacionalização da educação superior-Conceitos e práticas. Revista Educar, Curitiba, UFPR. 2006;28:107-124

[30] Knight J. Internationalisation of higher education: A conceptual framework. In: Knight J, de Wit H, editors. Internationalisation of Higher Education in Asia Pacific Countries. Amsterdam: European Association of International Education; 1994

[31] Wende, Van Der M. Internationalisation policies: about new trends and contrasting paradigms. Higher Education Policy. 2001;14(3):249-259

[32] Reis Pedro R, Camacho G. A avaliação da concretização do Processo de Bolonha numa instituição de ensino superior portuguesa. In: Revista Española de Educación Comparada. Espanha: Faculdade de Educação, UNED; 2009. pp. 41-59

[33] Bianchetti L. O Processo de Bolonha e a intensificação do trabalho 
na universidade: entrevista com Josep M. Blanch. Revista Educação e Sociedade. 2010;31(110):263-285

[34] Ferreira NSC, Pacheco JA. As políticas de formação de pesquisadores: Análise comparativa (Portugal-Brasil) em contextos de programas de pósgraduação. Revista Ensaio-Avaliação, Políticas Públicas e Educação.

2009;17(65):719-728

[35] Lima LC, Azevedo MLN, Catani AM. O Processo de Bolonha, a avaliação da educação superior e algumas considerações sobre a Universidade Nova. Avaliação, revista da Universidade de Sorocaba, Campinas. 2008;13(1):7-36

[36] Newman F. Saving higher education's soul. In: The Futures Project: Policy for Higher Education in a Changing World; Rhode Island: Brown University; 2000. pp. 1-19

[37] Veiga MAPT. Oportunidades e ameaças de Bolonha (um processo em curso) e a universidade europeia (um projecto em discurso) num contexto de globalização [Dissertação (Mestrado em Ciências Políticas)]. Porto: Universidade do Porto; 2003. p. 196 
Section 2

\section{Studies and Researches}





\title{
Evaluation of Human Capital as a Contribution to the Performance of the José Eduardo dos Santos University-Republic of Angola
}

\author{
Domingos João Fernandes and María Sotolongo Sánchez
}

\begin{abstract}
For institutions of higher learning such as universities, the performance evaluation teaching staff is profoundly significant in the realization of the institution's goals and objectives. It is also the social responsibility of these universities to ensure that the quality of education offered at their facilities is contextual and relevant to the graduates careers and the professions, which they undertake upon successful completion of these studies. As a nation committed to human capacity development, Angola recognizes and is continuously seek means to uphold exceptionally high standards of teacher performance as well as the general quality of services offered by the Angolan public universities. This chapter offers a summary of a comprehensive investigation dealing with $360^{\circ}$ and competency evaluation for teaching staff at universities. The objective of this study was to develop and implement a system of evaluation of the teacher and lecturer performance at the José Eduardo dos Santos University of the Republic of Angola. The methodology used for evaluation the strengths and weaknesses of 122 teachers, the strengths and weaknesses in their individual performance; it also presents an improvement plan based on their competences to enhance individual teacher performance.
\end{abstract}

Keywords: performance evaluation, management, human capital, teaching skills

\section{Introduction}

The world is changing at a fast pace and institutions of higher learning are constantly faced with the challenge to be dynamic in their approach in shaping the skills of the students and graduates who ultimately complete their studies to join the work force. Ospina [1], aptly points out that universities need to rise up to this challenge in order to allow graduates to have skill sets that optimize their performance in their chosen career fields. In an attempt to overcome these challenges, a paradigm of competitiveness, relevancy and effectiveness of graduate professionals' knowledge requirements is deemed necessary. The quality and effectiveness of the teachers, instructors and lecturers is fundamentally linked 
to the kind of interest and motivation for the subject matter; seeking other resources for further reading or knowledge development and the actual knowledge of the disciplines and actual competences the students and graduates attain that enable them to adapt in the workplace. The role and responsibility of the teaching staff is far reaching and it greatly contributes to the quality of graduates as they reach the workforce.

Undoubtedly, the role of the university teacher in the achievement of these goals is transcendental. The evaluation of the performance of university teacher has therefore become a very useful instrument for institutions of higher education that allows stakeholders to make decisions to improve and enhance the quality of the performance of the teachers and the teaching-learning process. In modern times, universities have a great challenge in developing performance evaluation systems, motivating a change in the daily duties and activities of teachers as they carry out their professional role of teaching [2].

Angola's current status on evaluation of the performance of human resources and especially of teachers in public universities is an ongoing concern that is mainly motivated by the need to raise standards and quality of education in general.

The course content, the skills and knowledge offered, the mode of transmission, i.e., the teacher-learning process, the teachers conduct and methods of offering teaching services are all part of the considerations that need to be evaluated for tertiary learning institutions in Angola.

Previous studies carried out from 2005 to the present on the situation of the system of higher education in Angola [3-7] revealed a whole set of weaknesses that hamper the effective performance of university teachers as summarized in Table 1

This unhealthy competition amongst professionals to join the teaching staff in institutions of higher learning with a defunct performance evaluation systems and by extension no professional code of performance of conduct severely affect the quality of education in Angola. The lack of pedagogical, instructive and research skills, sometimes leads to a situation where teaching staff do not act as facilitators of learning and therefore do not contribute to develop in the learners' creativitythese competences are not evaluated in their performance.

In addition, research carried out by [7-9] uncovered shortcomings in the existing evaluation of performance, such as the instrument for the evaluation of the performance of university teachers is the same as that used to evaluate the other public works (technical and administrative staff). This entails that the indicators ${ }^{1}$ defined in this instrument are very general and do not apply for the assessment of the competencies that must be measured in the performance of a teacher, thus rendering very subjective results that cause dissatisfaction and performances that do not enhance the improvement of the skills of the teaching staff. This all culminates into a situation that negatively affects the quality of the process of teaching and learning in the Angolan public universities.

Consequently, this problem, justified the need to develop a system of performance evaluation that stimulates a change in the daily activities of the Angolan University teaching. However, many of the Angolan public universities lack knowledge on how to evaluate the performance of their teachers because there are few relevant methodological instruments in use to evaluate them, much less plan of actions for the improvement of their skills which would contribute to the quality of the process of teaching-learning in educational institutions.

\footnotetext{
${ }^{1}$ The indicators defined for the evaluation of the performance are: professional competence, dynamism and initiative, the fulfillment of tasks, human relations at work, the professional adaptation, regularity, punctuality, and discipline, the appropriate use of the means of work, presentation and individual posture.
} 
Evaluation of Human Capital as a Contribution to the Performance of the José Eduardo dos... DOI: http://dx.doi.org/10.5772/intechopen.84844

Inadequate preparation of the teaching staff from the pedagogical point of view

Low standards are accepted and accepted as a norm so, a general culture has evolved around this where poorly trained teachers enter the workforce

Teachers in general do not receive comprehensive practical knowledge about teaching and learning assessment techniques, therefore, deficiencies in performance assessment initiate right from the teacher training process

A defunct performance evaluation system used by institutional managers has generated the status of complacence amongst teachers, in terms of their pursuit of excellence in their profession. The systems of performance evaluation do not make a distinction between teachers with superior performance or professionally competent compared to the insufficient performance or the incompetent teachers.

Financial gain is the main motivation for the vast majority of teachers to aspire to work at institution of higher learning, as the remuneration packages at these institutions is rather higher than at lower level of learning. These institutions offer better income but show indifference and apathy as to the improvement of the quality of the teaching-learning processes.

Source: own elaboration.

Table 1.

Challenges to the effective performance of the Angolan University teaching staff.

\section{Development}

The application of the procedure in the University José Eduardo dos Santos, has been developed taking into account the proposed principles. Phase 1 was fulfilled satisfactorily; a panel of experts, consisting of 19 people for the analysis of strategies and policies of Human Resources in alignment with the specific procedure proposed for these purposes was clearly defined. In addition, three awareness workshops were developed successfully.

The documentary analysis conducted, concluded that the performance evaluation process has the following limitations: the evaluation is carried out by the immediate superior head without participation of other stakeholders (teachers, students, and academic peers) and if one performs an analysis of the functions which a faculty teacher should perform according to the established category in the statutes of the teaching career from 1995 to the present, can easily ascertain that the performance indicators established in Decree 25/94 do not qualify to evaluate the competences of university teachers in alignment with the functions that must perform, therefore, are very general indicators that do not reflect the actual performance of the teacher.

Surveys were also applied to a sample of 122 teachers and 18 managers of the University José Eduardo dos Santos, supporting the results obtained from the application of the documentary analysis.

Further, the implementation of phase 2 as planned, would facilitate the evaluation of the performance of 122 teaching staff of the Jose Eduardo dos Santos University.

The analysis of the results is shown in Table 2, followed by subsequent conclusions highlighted as follows; out of 122 teaching staff at UJES: $23 \%$ of teachers were assessed "Insufficient", 64\% "Good" and 12\% "Very good". Actually, these results, demonstrate an improvement in the quality of the performance assessment process, in the first instance because it enabled to assess all full-time teachers based on indicators or performance criteria associated with their role in the UJES and secondly because enabled identifying those competencies where the teacher should improve their performance to contribute effectively to the results of the institution.

The ranges of the evaluation scale were defined taking into consideration the criteria of the experts, who assessed the scale in agreement with that defined in article 60 of the academic regime for the evaluation of students ranging from 0 to 20 . However, the most conventional scale is the one ranging from 0 to 100 , 
Total qualitative assessment performance

\begin{tabular}{lcccc}
\hline Scale & Frequency & \% & \% valid & \% cumulative \\
\hline Insufficient & 1 & 0.8 & 0.8 & 0.8 \\
\hline Sufficient & 28 & 23 & 23 & 23.8 \\
\hline Good & 78 & 63.9 & 63.9 & 87.7 \\
\hline Very good & 15 & 12.3 & 12.3 & 100 \\
\hline Total & 122 & 100 & 100 & \\
\hline Source: own elaboration. & & & & \\
\hline
\end{tabular}

Table 2.

Results of the application of the questionnaires of evaluation of the teaching staff of the UJES.

but, nevertheless, the previous scale (from 0 to 20) was correlated with the scale from 0 to 100, where each value of the scale multiplied by 5, as shown in Table 3 indicating the relationship between the two scales:

Generally, in Angola it is common to use the classifications of "Insufficient", "Sufficient", "Good", "Very Good" and "Excellent" in regards to assessment. For such purposes, the numerical ranges and the ranges established for the evaluation scale (REES) area as follows:
a. Insufficient (1) if REES $<50$
b.Sufficient (2) yes 50 REES $<65$
c. Good (3) yes 65 REES $<80$
d.Very Good (4) yes 80 REES $<90$
e. Excellent (5) if REES 90

Subsequently, phase 3 was also successfully fulfilled and an analysis of the process of evaluation of performance in the UJES (see Table 4), identified the lack of internal coherence between the policies of HR considering that the indicators related to the level of use of assessments of performance for the training and promotion, respectively, yielded values that indicate that these results are not used for the staff training process either for their promotion i.e. do not use these results for the evaluation of performance or to make the diagnosis of the needs of learning and in relation to this, of the UJES capacity building plan. Further, it stresses that the $64 \%$ of teachers evaluated as "good" and $12 \%$ as "Very good", show an improvement

\begin{tabular}{lc}
\hline Scale from $\mathbf{0}$ to $\mathbf{2 0}$ & Scale from $\mathbf{0}$ to $\mathbf{1 0 0}$ \\
\hline Insufficient $<10$ & $<50$ \\
\hline Sufficient $10-13$ & $50-65$ \\
\hline Good $14-16$ & $66-80$ \\
\hline Very good 17-18 & $81-90$ \\
\hline Excellent $\geq 18$ & $\geq 90$ \\
\hline Source: own elaboration. & \\
\hline
\end{tabular}

Table 3.

Representation of the relationship of both scales. 
Evaluation of Human Capital as a Contribution to the Performance of the José Eduardo dos... DOI: http://dx.doi.org/10.5772/intechopen.84844

\begin{tabular}{lc}
\hline Indicators & Results (\%) \\
\hline Degree of satisfaction with the results of the assessment of performance & 85 \\
\hline Degree of compliance with the process of evaluation of performance & 100 \\
\hline Evaluated teachers of insufficient & 1 \\
\hline Evaluated teachers of sufficient & 23 \\
\hline Evaluated teachers of good & 64 \\
\hline Evaluated teachers of very good & 12 \\
\hline Evaluated teachers of excellence & 0 \\
\hline Degree of use of the performance assessment for training & 24 \\
\hline Degree of use of the performance assessment for promotion & 76 \\
\hline Source: own elaboration. & \\
\hline
\end{tabular}

Table 4.

Results of the indicators of audit and control of the system of performance assessment in the José Eduardo dos Santos University.

\begin{tabular}{|c|c|c|c|c|c|}
\hline Actions & $\begin{array}{l}\text { Determine the } \\
\text { needs of training } \\
\text { according to the } \\
\text { results of the } \\
\text { performance } \\
\text { assessment }\end{array}$ & $\begin{array}{l}\text { Develop and provide } \\
\text { teacher training plan }\end{array}$ & $\begin{array}{l}\text { Develop the } \\
\text { process of } \\
\text { promotion } \\
\text { according to the } \\
\text { results of the } \\
\text { performance } \\
\text { assessment }\end{array}$ & $\begin{array}{l}\text { Design and } \\
\text { implement } \\
\text { scientific } \\
\text { research projects }\end{array}$ & $\begin{array}{l}\text { Develop and } \\
\text { implement } \\
\text { a strategy } \\
\text { for doctoral } \\
\text { training }\end{array}$ \\
\hline $\begin{array}{l}\text { Who is } \\
\text { responsible } \\
\text { for }\end{array}$ & $\begin{array}{l}\text { Head of the } \\
\text { scientific } \\
\text { Department and } \\
\text { the Head of the } \\
\text { Department of HR }\end{array}$ & $\begin{array}{l}\text { Head of the } \\
\text { scientific } \\
\text { Department and } \\
\text { the Head of the } \\
\text { Department of HR }\end{array}$ & $\begin{array}{l}\text { Scientific } \\
\text { Council of the } \\
\text { organic unit and } \\
\text { Department of } \\
\text { HR }\end{array}$ & $\begin{array}{l}\text { Teachers and } \\
\text { Scientific } \\
\text { Council of the } \\
\text { organic units }\end{array}$ & $\begin{array}{l}\text { Scientific } \\
\text { Council of the } \\
\text { organic units }\end{array}$ \\
\hline $\begin{array}{l}\text { What should } \\
\text { you do }\end{array}$ & $\begin{array}{l}\text { Identify the } \\
\text { training needs of } \\
\text { teachers from the } \\
\text { accusations made } \\
\text { in the performance } \\
\text { assessment }\end{array}$ & $\begin{array}{l}\text { Develop the training } \\
\text { plan }\end{array}$ & $\begin{array}{l}\text { Promote teachers } \\
\text { based on their } \\
\text { performance }\end{array}$ & $\begin{array}{l}\text { Design projects } \\
\text { according with } \\
\text { the research } \\
\text { lines }\end{array}$ & $\begin{array}{l}\text { The doctoral } \\
\text { training } \\
\text { strategy }\end{array}$ \\
\hline $\begin{array}{l}\text { When it } \\
\text { needs to do }\end{array}$ & February month & March month & $\begin{array}{l}\text { May-November } \\
\text { month }\end{array}$ & Annual & Annual \\
\hline Where is & $\begin{array}{l}\text { Department or } \\
\text { faculty }\end{array}$ & $\begin{array}{l}\text { Department or } \\
\text { faculty }\end{array}$ & $\begin{array}{l}\text { Department or } \\
\text { faculty }\end{array}$ & Faculties & Faculties \\
\hline Why does & $\begin{array}{l}\text { To promote the } \\
\text { training and } \\
\text { development plan }\end{array}$ & $\begin{array}{l}\text { To promote the } \\
\text { continuous training } \\
\text { of their teachers }\end{array}$ & $\begin{array}{l}\text { To promote } \\
\text { teachers' } \\
\text { category }\end{array}$ & $\begin{array}{l}\text { To encourage } \\
\text { research and the } \\
\text { introduction of } \\
\text { scientific results }\end{array}$ & $\begin{array}{l}\text { To promote } \\
\text { the training of } \\
\text { doctors }\end{array}$ \\
\hline $\begin{array}{l}\text { How is it } \\
\text { made }\end{array}$ & $\begin{array}{l}\text { From the } \\
\text { accusations made } \\
\text { in the performance } \\
\text { assessment and } \\
\text { the results of } \\
\text { questionnaires to } \\
\text { diagnose the needs } \\
\text { of training }\end{array}$ & $\begin{array}{l}\text { According to the } \\
\text { diagnose the needs } \\
\text { of training planned } \\
\text { actions, manager's } \\
\text { compliance date, the } \\
\text { budget and the place } \\
\text { where the training } \\
\text { will take place }\end{array}$ & $\begin{array}{l}\text { Based on the } \\
\text { results of the } \\
\text { performance of } \\
\text { the teachers it } \\
\text { invites public } \\
\text { tenders of } \\
\text { promotion }\end{array}$ & $\begin{array}{l}\text { In accordance } \\
\text { with the lines } \\
\text { of research and } \\
\text { the funding } \\
\text { available to } \\
\text { develop research } \\
\text { projects }\end{array}$ & $\begin{array}{l}\text { Doctoral } \\
\text { training } \\
\text { strategy is } \\
\text { elaborated in } \\
\text { accordance } \\
\text { with the lines } \\
\text { of research }\end{array}$ \\
\hline
\end{tabular}

Table 5.

Actions to improve program. 


\begin{tabular}{llccccc}
\hline Descriptive statistics & \multicolumn{1}{c}{ Minimum } & Maximum & Media & Dev. Tip. & Variance \\
\hline Actuality & 19 & 4 & 5 & 4.53 & 0.513 & 0.263 \\
\hline Utility & 19 & 4 & 5 & 4.58 & 0.507 & 0.257 \\
\hline Reliability & 19 & 4 & 5 & 4.47 & 0.513 & 0.263 \\
\hline Feasibility & 19 & 4 & 5 & 4.53 & 0.513 & 0.263 \\
\hline Relevance & 19 & 3 & 4 & 3.63 & 0.496 & 0.246 \\
\hline Novelty & 19 & 4 & 5 & 4.58 & 0.507 & 0.257 \\
\hline $\begin{array}{l}\text { Transferability to } \\
\text { other contexts }\end{array}$ & 19 & 3 & 4 & 3.37 & 0.496 & 0.246 \\
\hline Source: own elaboration. & & & & & & \\
\hline
\end{tabular}

\section{Table 6.}

Criteria of validation.

in the quality of this process. Based on the difficulties identified in the performance of the teachers in the UJES, was deemed necessary to design the programme of improvement actions listed in Table 5.

It is equally important at all stages to identify the necessary resources (staff, technological resources, financial resources, etc.).

Table 6 portrays a summary the different evaluated criteria, as well as the descriptive statistical estimator's employees results in a Linker scale of category (5). The expert opinions expressed a level of consistency higher than 0.83 according to the coefficient of concordance of Kendall W.

The generality of criteria concerning novelty and utility, as well as to the actuality, reliability and feasibility of these research proposals, have yielded values averaging between four (4) and five (5) for all items of the questionnaire, leading to scores higher than 4.47 points in all cases, except for the relevance and transferability. These results indicate that the procedures proposed in the framework of this research are:

Feasible and applicable to the universities under study thus contributing to demonstrate its relevance, capacity description, explanation and prediction, in relation to the performance assessment;

Which corresponds to the latest trends on the performance assessment that provides strong evidence to show the theoretical and practical context;

They were understandable and comparable amongst staff involved, in frames, which sets its inherent complexity, which speaks in favor of its parsimony; and in the opinion of this author, and even the experts, it is possible to extend/extrapolate to other Angolan public universities, with their corresponding adjustments, thus demonstrating its transferability.

The implementation process of the system teacher evaluation were developed based on the regulation elaborated wherein the standards for the evaluation of performance were clearly defined and applied to the 122 full-time professors of the faculties, polytechnic colleges that constitute UJES. The regulation was mandatory and backed in the official regulations in the Republic of Angola.

\section{Conclusions}

1. Through the general procedure for the performance assessment of the teachers at Angolan public universities were able to evaluate 122 teachers in UJES, 
representing the universe of the targeted institution, as well as identify the main strengths and weaknesses in the performance of its teachers in the context of Angolan public higher education, particularly characterized at the subject of study.

2. The chapter concludes that lack of coherence between the policies and practices of Human Resources in relation to the performance assessment results, as well as by the fact that the performance assessment results are measured erroneously based on very general indicators and not on the basis of the competences of teachers that influence the results of the University, which speaks in favor of its relevance.

3. The evaluation control system of performance evaluation indicators allowed to identify and deploy a feasible and relevant set of policies and programs of action in the UJES, all of which, ultimately, properly managed, particularly the studied University. In general, it will gradually result in improvement of the level of performance of its teachers, which rendered the ability to draw policies and programs of action, consistent with the need of improving the quality of the teaching-learning process.

4. With the full implementation of the proposed procedure in the UJES, it were found out that it is feasible, suitable and effective methodological tool to gradually improve the performance evaluation process of the Angolan public universities and that proving, with its coherent application to the specific subject or case studies. In particular, its capacity of description, explanation and the prediction, logical consistency, flexibility, moderation, perspective and relevance in the framework of the research, which, together with those derived from their adoption and implementation, ascertained the verification of the general hypothesis of the proposed research field.

\section{Author details}

Domingos João Fernandes ${ }^{1 *}$ and María Sotolongo Sánchez ${ }^{2}$

1 University José Edaurdo dos Santos, Huambo, Angola

2 University Central “Marta Abreu” de las Villas, Santa Clara, Cuba

*Address all correspondence to: jfernandes07@yahoo.com.br

IntechOpen

(C) 2019 The Author(s). Licensee IntechOpen. This chapter is distributed under the terms of the Creative Commons Attribution License (http://creativecommons.org/licenses/ by/3.0), which permits unrestricted use, distribution, and reproduction in any medium, provided the original work is properly cited. (cc) BY 


\section{References}

[1] Ospina. currículo por competencias en la Universidad de La Sabana [Internet]. 2006. Available from: http:// www.scielo.org.co/pdf/aqui/v6n1/ v6n1a11.pdf [Accessed:08 August 2018]

[2] Daura. las estrategias docentes al servicio del desarrollo del aprendizaje autorregulado [Internet]. 2006. Available from: http://www.scielo.cl/ pdf/ested/v37n2/art04.pdf [Accessed: 06 July 2018]

[3] Nascimento A. Linhas Mestras para a Melhoria da Gestão do Subsistema do Ensino Superior. Luanda, Angola: Diario da Republica; 2005

[4] Buza A. Por Um Ensino Superior de Qualidade nos Países e Regiões de Língua Portuguesa [Internet]. 2012. Available from: http://ciencia. ao/eventos/item/749-chamada-deresumos-para-a-7-conferencia-doforum-da-gestao-do-ensino-superiornos-paises-de-lingua-portuguesa-forges [Accessed: 09 August 2018]

[5] Chimpolo J. Tecnología para la gestión de recursos humanos en instituciones de educación superior angolanas. Caso de la Universidad Agostinho Neto [thesis]. Cuba: University of Holguín

[6] Simões C. Ensino superior em Angola: desafios e oportunidades ao nível institucional de ensino superior. Revista FORGES—Fórum da Gestão do Ensino Superior nos Países e Regiões de Língua Portuguesa; 2016. p. 69

[7] Domingos F et al. La evaluación del desempeño por competencias: Percepciones de docentes y estudiantes en la educación superior. Formación Universitaria. 2016;9(5):15-24. DOI: 10.4067/S0718-50062016000500003. [Accessed: 02 December 2018]
[8] Fernandes D. El rol del estudiante en el proceso de evaluación del desempeño del docente universitario. El caso de la Universidad José Eduardo dos Santos. República de Angola.

Conferencia Internacional de Ciencias Empresariales; 2012

[9] Fernandes D. Procedure for the evaluation of the teaching performance in the public angolan universities [Internet]. 2016. Available from: http:// scielo.sld.cu/scielo.php?script=sci_art text\&pid=S1815-59362016000200007 [Accessed: 09 August 2018] 


\title{
Chapter 3
}

\section{Education Systems in Eurasia}

\author{
Rashad Kurbanov, Ramin Gurbanov and Asiya Belyalova
}

\begin{abstract}
This chapter is dedicated to national-level systems of education in Eurasian states and their unification within a framework of international regional organizations, where these states participate. The Eurasian states participate not only in CIS but also in other international regional organizations, but researchers do not always consider this fact. The subjects of this research are (a) the elements of the education system and links between them, (b) state bodies and other state entities which regulate the educational relations, and (c) innovation politics in education in every state: network universities and digital technologies. The last one is more relevant due to differences of the intended role of network universities, and the use of digital technologies varies from one legal system to others. The methods of implementation and use of digital technologies are also significantly different.
\end{abstract}

Keywords: education, international law, Eurasia, network university, digital technologies

\section{Introduction}

Education as a sphere of integration of states usually does not enjoy the attention of the researchers. At the same time, it is obvious that the unification of the educational programs and standards is the strategic basis for the junction of states. Education based on common principles contributes to the emergence of a unified terminology, techniques, ways, and styles of thinking in different states. In addition, a specialist gets high-quality education in an educational institution, and in the future it will predetermine his choice if he needs to improve his qualifications and to choose an educational institution for his children. Education of the political, business, and scientific elite abroad (mainly in the educational institutions of the EU and the USA) gave the states, where these educational institutions were located, certain political dividends. We should not lose sight of such a modern phenomenon as "the export of educational services" [1]. Almost all sustainable integration associations affect the field of education.

So, the area of education, along with international justice and the protection of human rights, is a sphere of cooperation in the EU and CE [2]. In the structure of the Council of Europe was created and operates the Committee on Culture, Science, Education and Mass Media (AS/Cult) [3].

Similar processes are taking place in the Eurasian space. For example, a few states of the Eurasian Economic Union (EEU) participate in some CE and EU projects [4]. In Europe, as a response to the challenges of the postindustrial economy of knowledge, the Bologna Declaration on the creation of a common European Higher Education Area (the Bologna Declaration) was developed and adopted in Bologna on June 19, 1999. The Bologna Declaration outlined the six priorities till 
2010 to reform European higher education. Each of the 33 signatory countries adopted national action plans. All EEU member states except Kyrgyzstan (Russia, Kazakhstan, Armenia, and Belarus) as well as such Eurasian states as Azerbaijan, Georgia, Moldova, and Ukraine are participants of the Bologna process, which was developed within the framework of European integration.

Moreover, the EEU member states are also involved in the work of other integration associations. This means that the lack of integration in an area of public relations within the EEU automatically entails its inclusion in the "orbit" of other integration associations. A typical example is Kazakhstan, which is not a full member of the Organization for Economic Cooperation and Development (OECD) [5] but has undertaken several commitments to restructure the education system following the recommendations of this international organization.

\section{Legal bases of interaction in the Eurasian space}

It should be noted that even during the Soviet era, the Minister of Education of the USSR, G. Yagodin, prepared a number of normative documents on the transition to an education system similar to Bologna. This system was almost integrated at the Faculty of Economics of the Lomonosov Moscow State University ${ }^{1}$ and the Peoples' Friendship University of Russia ${ }^{2}$. In 1988, the Provisional Research and Development Team "School" was established, headed by the future Minister of Education of the Russian Federation, E. D. Dneprov. In this center, a new educational policy was developed, based on the ideas of variability and free choice at all levels of the education system.

The cooperation of the Eurasian (post-Soviet) ${ }^{3}$ states in the field of higher education began with the signing of the Agreement on Mutual Recognition and Equivalence of Education Documents, Academic Degrees and Titles of November 24, 1998, by the Governments of Russia, Belarus, Kazakhstan, and Kyrgyzstan [6].

Since April 27, 2003, based on the protocol on the introduction of amendments and additions, Tajikistan has joined to this Agreement [7].

Let us consider the interaction of Eurasian states within the main integration associations, as well as at their national level.

\subsection{Commonwealth of independent states}

In 2001, the concept of forming a single (common) educational space of the Commonwealth of Independent States (CIS) was adopted [8].

At the end of 2006, a model educational code was approved for the CIS member states [9]. For the first time, it proclaimed the creation of a single educational space within the CIS. The common educational space of the Commonwealth of Independent States is defined in this document as a space characterized by (1) common principles of state policy in education; (2) consistency of state educational standards, programs, education levels, normative terms of education at each

\footnotetext{
${ }^{1}$ One of the oldest largest classical universities in Russia and one of the centers of national science and culture, located in Moscow. Created in 1755

2 The Peoples' Friendship University of Russia is a multi-profile university in Moscow, Russia. Established on February 5, 1960, as the Patrice Lumumba Peoples' Friendship University, since February 5, 1992, is the Peoples' Friendship University of Russia.

${ }^{3}$ In this study, the Eurasian states are the states participated in the former Union of Soviet Socialist Republics (USSR) (1922-1991), except Baltic states (Latvia, Lithuania, and Estonia, currently members of the EU).
} 
level, provisions and requirements for training, and certification of scientific and scientific-pedagogical personnel; and (3) equal opportunities and free exercise of the rights of citizens to receive education in the state and municipal educational institution in the territory of the CIS member states (Article 1).

In 2013, at the 39th plenary meeting of the Inter-Parliamentary Assembly of the CIS member states (Decree No. 39-6 of November 29, 2013), a new edition of this model code was adopted [10].

On December 10, 2010, at a meeting of the council of heads of CIS member states, representatives of the Republic of Armenia, the Republic of Belarus, the Republic of Kazakhstan, the Republic of Moldova, the Kyrgyz Republic, the Russian Federation, and the Republic of Tajikistan and Ukraine decided to create a CIS Network University based on the Peoples' Friendship University of Russia. In 2015, the Republic of Azerbaijan joined the Network University. Raison d'etre (meaning of existence) of the Network University is the possibility for student to study in the several educational structures at the same time, including foreign ones. In practice, this means the possibility of undergraduate study (bachelor's program) at a basic university and graduate (master program) and postgraduate studies-in partner universities.

The governing body of the Network University is the Coordinating Council of the Network University, which is composed of representatives from all partner universities. Researchers admit that the Network University of the CIS is, overall, a counterpart to the EU Erasmus Mundus program [11].

\subsection{Eurasian economic union}

Today, one of the most relevant issues in the framework of the EAEU integration is the creation of a single educational space of states. The need to integrate the higher education systems of the EAEU member states is the basis for the successful integration cooperation. At the same time, the Treaty on the Eurasian Economic Union, signed on May 29, 2014 (the Treaty on EAEU) [12], does not provide for the formation of a supranational educational space, although it is indicated that the EAEU was created to ensure "conditions for the stable development of the economies of the member states in the interests of raising the living standards of their populations; the formation of a single market for goods, services, capital and labor resources; comprehensive modernization, cooperation and increasing the competitiveness of national economies in the global economy" (Article 4 of the Treaty). Only Article 97.3 of the Treaty on the EAEU regulates relations concerning mutual recognition of documents on education while excluding from the scope of the Treaty documents on education in such professions as medicine, pharmaceuticals, pedagogical sciences, and law.

The main directions for implementing the digital issues of the EEU until 2025, approved by the Decision of the Supreme Eurasian Economic Council No. 12 of October 10, 2017, "On the Main Directions for Implementing the Digital Agenda of the Eurasian Economic Union until 2025," also do not contain any mention of education - the digital transformation of education was not mentioned in the list of directions of the digital economy development (Section III of this Decision).

Back in 2009, Decision No. 463 of the Interstate Council of the Eurasian Economic Community (EURASEC, 2001-2014) was the international economic organization of several former Soviet republics, which created to effectively promote its participants in the process of forming the Customs Union and the Common Economic Space, as well as the realization of other goals and objectives related to the deepening of integration in the economic and humanitarian fields. EURASEC was abolished in connection with the creation of the Eurasian Economic Union "On the Agreement on Cooperation of the Member States of the Eurasian Economic Community in the Field of Education" of December 11, 2009 [13] and approved 
an agreement in accordance with Articles 2, 3, and 6 of which EURASEC member states agreed to support direct links between universities and scientific organizations on the basis of cooperation agreements, to promote the development of academic mobility of students and teachers. Also, for the implementation of this international treaty, the states came to an agreement on the establishment of the Council on Education under the EURASEC Integration Committee (the Council is the legal successor to the Council for Mutual Recognition and Equivalence of Education Documents, Academic Degrees and Titles under the EURASEC Integration Committee, which acted on the basis of the Agreement between the Government of the Republic of Belarus, the Government of the Republic of Kazakhstan, and the Government of the Republic of Tajikistan on mutual recognition and equivalence of education certificates, academic degrees, and titles of November 24, 1998, and the Decision of the EURASEC Integration of September 19, 2002, No. 146.), which operates in accordance with the Statute on the Council, approved by the EURASEC Integration Committee [14]. It is regrettable to note that the provisions of this international treaty are "dissolved" in the norms of the Treaty on the EAEU, which does not mention the integration of the EAEU member states in the field of education.

Of course, the EAEU Treaty included the Cooperation Agreement of the Member States of the Eurasian Economic Community in education in 2009 to the list of international treaties that continue to operate, however limiting their validity to "the part in which they can be implemented in the absence of the EURASEC bodies mentioned in them, dissolved in accordance with the Treaty on the EURASEC." We are agreeing with S.M. Yun, who said "...the soft wording 'can be fulfilled' and the absence of norms in the EAEU Treaty creates a situation in which the question of developing multilateral cooperation in the field of education within the EAEU is more a matter of political negotiations than regulation" [15].

The day after the leading universities signed the Memorandum of Understanding on the establishment of the Eurasian Network University of April 12, 2016 [16], the Ministry of Education and Science of the Russian Federation in the meeting of the heads of state executive authorities of the EAEU member states in the area of higher education and science, offered to sign the Memorandum on Cooperation in educational and scientific-technological interaction in the Eurasian region between the ministries of education and science of the Union of April 13, 2016 [17]. This document was signed by all EAEU member states except Kazakhstan. It was aimed at coordinating education policies. The implementation of this project was delayed due to structural changes in the Russian public administration in the field of higher education and science.

In 2018, the chairmanship of the EAEU passed to Russia. It became possible to distinguish two completely specific areas of Eurasian integration in higher education: (1) approaching the educational standards based on the needs of the Eurasian common market and (2) creation of Eurasian common scientific clusters and campuses based on universities, large enterprises, academies of science for the development of new technologies, and Eurasian common import substitution with centralized financing [18].

\subsection{Shanghai cooperation organization}

On August 16, 2007, at the Summit of Heads of Shanghai Cooperation Organization (SCO) member states, the leaders of the Kazakhstan, China, Russia, Kyrgyzstan, and Tajikistan supported the Russian initiative to create on a multilateral basis the Network University of SCO member states, and on October 28, 2008, in Astana (Kazakhstan) at the meeting of the ministers of education of the SCO member states, the concept of the creation and functioning of the SCO University 
was signed. The educational network of the SCO University includes 79 leading universities of these countries and Belarus [19].

\subsection{BRICS summit}

Russia also participates in BRICS Network University. According to paragraph 64 of the updated plan of activities of the Russian chairmanship in BRICS (approved by Presidential Instruction No. Pr-172 of 29.01.2015) [20], the State Policy Department for Higher Education of the Russian Ministry of Education has compiled a list of universities for participation in the BRICS Network University.

The BRICS Network University provides graduate (master) and postgraduate programs, as well as coordination of the international research.

On July 5-7, 2018, BRICS Network University held the conference "Unlocking BRICS Universities' Partnerships: Postgraduate Education, Opportunities and Challenges" in Stellenbosch (South Africa). It identified six main areas of research: energy; information technologies; information security, ecology, and climate change; economics; water resources; and the threat of pollution. International Thematic Groups (ITGs) were created to exchange their national research and practical experience in these areas of knowledge.

\subsection{Russian Federation}

The Russian Federation (Russia) joined the Bologna process on September 19,2003 . The use of a system based on credit units in higher professional education began in Russia even before the official entry to the Bologna process. Thus, in 2002, the Ministry of Education of the Russian Federation adopted the "Methodology for calculating the labor intensity of the main educational programs of higher professional education in credit units" [21] and sent it to higher educational institutions using credit units to account for the labor intensity of the students' academic load.

In the Russian education system, the credit system received the official namethe system of "credits."

According to the Constitution of the Russian Federation (point "e," Part 1, Article 71) [22], education and science are under the joint jurisdiction of the Russian Federation and the constituent entities of the Federation.

On May 15, 2018, the Decree of the President of the Russian Federation No. 215 "On the Structure of Federal Executive Bodies" [23] established the Ministry of Science and Higher Education of the Russian Federation. Under this Ministry there is the Federal Service for Supervision in Education and Science (Rosobrnadzor). Its activity includes licensing or authorization in higher education; certification of researchers and teachers, as well as graduates; confirmation and nostrification of education documents; etc.

On December 19, 2012, by the Decree of the President of the Russian Federation No. 1666, the "Strategy of the State National Policy of the Russian Federation for the period up to 2025" was approved [24].

This Strategy proclaims the development of the Russian education system as one of the priorities of the state national policy in the following areas:

- Training, retraining, and advanced training of teaching staff.

- Assistance in the educational (training) migration of Russian citizens, including the purpose of obtaining education and advanced training in professions that are of great demand 
On May 9, 2017, the Decree of the President of the Russian Federation "On the Strategy for the Development of the Information Society in Russia for 2017-2030" [25] was signed. According to this Decree, it is supposed to provide conditions for scientific and technical creativity, including the creation of platforms for self-realization of educational and scientific workers; to use and develop various educational technologies, including distance learning, e-learning, in the implementation of educational programs; to establish sustainable educational links with compatriots living abroad, foreign citizens, and apatrides who speaks Russian language, including through information and communication technologies; and to develop and implement the partnership programs of educational institutions of higher education and Russian high-tech organizations, including improving educational programs.

On the basis of this Decree, by the Order of the Government of the Russian Federation of July 28, 2017, No. 1632-p, the program "Digital Economy of the Russian Federation" was approved [26].

This program states that the quantity of personnel and the compliance of educational programs with the needs of the digital economy are insufficient. It is recognized that there is a serious shortage of personnel in the educational process at all levels. The procedures of the final certification do not use enough digital tools of educational activities; the process is not included integrally in the digital information environment.

At the same time, it was pointed that there is an infrastructure of science and innovations in Russia; it is represented by various development institutions, technology parks, and business incubators, which can and should be used to develop the digital economy. According to this program, five basic directions of development of the digital economy in the Russian Federation are defined for the period up to 2024, including not only education itself but also the formation of research competencies and technical groundwork.

The main objectives of the direction concerning personnel and education are:

- Creating the conditions for training the staff for digital economy

- Improving the education system, which should provide the digital economy with competent staff

- The labor market based on the requirements of the digital economy

- Creating a motivation system for the development of the necessary competencies and the participation of staff in the development of the Russian digital economy

As the main objective of the direction concerning the formation of research competencies and technological groundwork, this program calls the creation of a support system for search and applied research in the digital economy (research infrastructure of digital platforms), ensuring technological independence in each area of passthrough digital technologies that are globally competitive, and national security.

\subsection{The Republic of Kazakhstan}

The Law of the Republic of Kazakhstan (Kazakhstan, RK) of February 18, 2011, No. 407-IV “On Science” [27] and the State Program for the Development of Education for the years 2011-2020 [28] have created a new group like the Russian higher educational institutions_- "Research University" and "National Research 
University" [29]. This legal status implies teaching, learning, and research at all levels of education.

The State Program for the Development of Education and Science for 2016-2019 was approved by the Decree of the Kazakh President No. 205 of March 1, 2016 [30], as well as by the Decree of the Kazakh Government of July 24, 2018, No. 460 [31]. At the higher education level, the main objectives of this program are developing skills that are more relevant to the labor market, more fully integration of Kazakhstan into the European Higher Education Area, improving the interaction between education, science, and industry, promoting the commercialization of research, strengthening national self-awareness, and encouraging active civil and social responsibility.

The feature of the legal status of non-state universities of Kazakhstan is that they can exist in the form of joint-stock companies (JSC) (in 2015, the network of higher educational institutions of Kazakhstan included 64 private universities (including 10 joint-stock companies) and 61 state universities). Their main shareholder is, as a rule, the ministry or the government itself. JSC are commercial organizations, but nonprofit units may be established within them).

Noting Bologna system, the Kazakhstan system of academic degrees chose a gradual transformation, suggesting the existence of a transition period. In the transition period of 2005-2011, in parallel, the degree of the candidate and the Doctor of Science and the new degree of the Doctor of Philosophy $(\mathrm{PhD})$ coexisted. At the same time, the new degree of the $\mathrm{PhD}$, being formally equated with the candidate, was perceived in practice as more valuable [32].

Another education area, where the education management system is still of an intermediate nature, is the education quality control. In Kazakhstan, there are accreditation and attestation at the same time, which are opposed to each other. The old form of quality control—attestation—is a rigid form of quality control. Accreditation is voluntary. Attestation is carried out every 5 years for quality control based on state standards and is the basis for higher educational institutions to obtain permission to carry out their activities.

Two national accreditation agencies, the Independent Kazakhstan Agency for Quality Assurance in Education (IAQA) [33] and the Independent Accreditation and Rating Agency (IARA) [34], were established in 2008 and 2011, respectively. Their responsibility is to accredit the higher educational institutions as well as the education programs. These agencies became full members of the European Association for Quality Assurance of Higher Education-IARA on November 30, 2016, and IAQA on February 13, 2017 [35].

The Decree of the Kazakh Government No. 827 of 12.12.2017 approved the State Program “Digital Kazakhstan” [36]. Thus, this Decree includes, inter alia, increasing digital literacy in vocational and higher education. It is recognized that the "digital leap" in the country is impossible without a change of approaches to education and without retraining of staff. Earlier, in the 1990s of the twentieth century, the state program on accelerated industrial-innovative development started, the Bolashak (future) international education program, was initiated [37]. In the system of higher, postgraduate education on the basis of three specialties, the subject of "Information and Communication Technologies" (ICT) was introduced, which provides students with basic knowledge of the use of ICT in practice within the chosen profession.

\subsection{The Republic of Armenia}

On May 19, 2005, the Republic of Armenia (Armenia) signed the Bologna Declaration [38]. The agreement between the Ministry of Education and Science of 
the Russian Federation and the Ministry of Education and Science of the Republic of Armenia on cooperation in education [39] was signed earlier on July 13, 2004, but did not enter into force. The Bologna system was withdrawn only medical education.

It should be noted that introduction of the Bologna education system in Armenia is rather positive [40]. The credit rating system in universities under Bologna system competes in Armenia with the traditional system of students' knowledge assessment adopted in Russia, which is adopted in universities focused on the Russian education model. The largest higher educational institution of this kind in Armenia is the Russian-Armenian University (RAU). The university was founded in Yerevan in 1997, in accordance with the Agreement between the Government of the Russian Federation and the Government of the Republic of Armenia [41].

In accordance with the mentioned interdepartmental Agreement on cooperation in education of July 13, 2004, the State Institute for Advanced Studies and Retraining in Informatics of the Republic of Armenia granted the status of the basic organization of the CIS in sphere of education of persons with disabilities and unemployed citizens of the EAEU states.

State universities in Armenia are autonomous nonprofit legal state entities that operate in accordance with government policies. Universities independently determine their budget and use of funds received from non-state sources. Funds received from the state budget are only part of the general budget of the university and can be used for a specific purpose in accordance with the standards established by law. Universities are also free to form their internal organizational structure [42].

Student learning outcomes are evaluated based on exams and tests, which are conducted in written or oral form. Exam results are graded according to classification systems that vary significantly among institutions (5-, 10-, or 20-point marking scales, 4-point graduation of letters A-F, etc.) [43].

The main educational program is undergraduate (bachelor's) degree; in higher educational institutions, it takes 4 years, and for medical specialties, it is 5 years. The duration of training in the program of specialty is 5 years [44]. Master's qualifications are awarded to persons with a bachelor's degree or specialist, according to the results of at least 1 year of vocational education program. The degree provides access to postgraduate studies based on the results of entrance examinations of applicants. At the end of graduate school and successful thesis, a graduate student receives a $\mathrm{PhD}$ degree.

\subsection{The Republic of Belarus}

The main law regulating the sphere of education is the Code of the Republic of Belarus (Belarus) No. 243-3 “On Education," adopted on January 13, 2011 [45]. In accordance with this document, the state policy in education should be based on the principles of the priority of human rights, ensuring equal access to education, compulsory general basic education, integration into the world educational space, secular nature, and environmental orientation of education. The Belarus Code "On Education" also provides for the development of education, considering the tasks of the socioeconomic development of the state and the state-public nature of education management. Even though formally these principles can be called progressive, the degree of their real implementation in the education system of Belarus causes doubts among researchers [46].

The Resolution of the Council of Ministers of the Republic of Belarus of March 28, 2016, No. 250 approved the State Program "Education and Youth Policy" for 2016-2020 [47].

According to this document, institutions of higher education in Belarus include 43 public and 9 private universities [48]. They are divided to universities (33), 
academies (8), institutes (10), and higher college (1). The main difference between institutes and universities is that they train narrow specialists, and in higher college, you can get a higher education only at the first level. The Ministry of Education of the Republic of Belarus is the only state body for implementing state policy in education, organization of scientific research, and education international cooperation. In particular, the Ministry has jurisdiction over the quality control of education, coordination of the activities of state educational institutions, and licensing of educational institutions. It also organizes the development of educational programs and standards with the participation of educational institutions, provides scientific and methodological support for education, etc. [49].

Local executive and administrative bodies of education have to develop and submit for approval to local councils of deputies the programs for development of all levels of education in the relevant territorial unit. They are responsible for the organization of advanced training and retraining of specialists of educational institutions subordinate to them, as well as providing graduates with the job. In addition, local authorities are charged with the responsibility for the material, technical, and economic support of educational institutions [50].

The universities can submit their requirements and recommendations to state authorities through the Republican Council of Rectors [51]. Another feature of the Belarus education system is that, according to the Belarus Code on Education, employment of graduates of higher educational institutions occurs through distribution based on the received specialty and qualification (distribution does not apply to graduates of evening and extramural education and full-time graduates who have received education on a fee basis. The terms of compulsory work in the direction of work for graduates who have received education at the expense of the republican budget range from 1 to 5 years, depending on the qualifications obtained).

Back in 1993, the Republic of Belarus ratified the European Cultural Convention; in 2002 Belarus participated the Lisbon Convention of 1997 "On the recognition of qualifications relating to higher education in the European Region" [52]. Preparation for entry into the European Higher Education Area was resumed in 2010, and in 2011 the Ministry of Education of Belarus formally sent an application to the Bologna Secretariat [53].

However, the Public Bologna Committee presented its own independent assessment of the situation of higher education in Belarus. The higher education system of Belarus must be deeply reformed [54]. As a result, Belarus has become the only state that was not accepted into the European Higher Education Area immediately upon application. In 2012-2015 the new structure of higher education was formally approved (bachelor, master, and third degree-doctoral—remains beyond the scope of reform [55]); the issue of the European Diploma Supplement on Higher Education became mandatory.

Only on May 15, 2015, at the conference of ministers of education of the European Higher Education Area member states in Yerevan (Armenia), Belarus received the status of a participant in the Bologna process [56].

\subsection{The Republic of Tajikistan}

In the Republic of Tajikistan (Tajikistan), there are 63 organizations providing science and scientific services. For the period 2011-2015, the number of specialistsresearchers has increased almost in 1.5 times. Mechanisms for the formation of a system for scientific staff training have been created and introduced; a national system for the protection of scientific work and obtaining a scientific degree is being developed, including as part of the gradual transformation of postgraduate studies into a doctoral program (PhD) [57]. 
The main normative act regulating relations, including higher education relations, is the Law of the Republic of Tajikistan of May 17, 2004, No. 34 "On Education" [58].

By the Decree of the Tajikistan Government of June 30, 2012, No. 334, the National Strategy for the Development of Education of the Republic of Tajikistan until 2020 was approved [59]. In particular, it states the completion of the transition of the higher education system to the Bologna model. At the same time, in this program there is no mention of "digitalization" of higher education in Tajikistan.

The Ministry of Education and Science of the Republic of Tajikistan [60] is the highest executive body of state authority in sphere of education and science; it implements a unified state policy and regulates legal standards in education and science and in areas of training, education, scientific and technical activities, custody and guardianship, as well as support and social protection of students and pupils of educational and scientific institutions. It is also entrusted with coordinating and controlling the activities of educational and scientific institutions directly and through state local education authorities in collaboration with ministries and departments, local executive bodies of state power, the public, and other organizations.

Today, in the Tajikistan universities, a gradual transition to a credit system of education is being carried out, and the scope of application of new information technology tools in the educational process is expanding. This system has already been implemented in almost all universities. The transition to a credit system of education has allowed to broaden the prospects for academic mobility of teachers and researchers of Tajikistan with higher educational institutions of the CIS countries and other countries.

Higher professional institutions in Tajikistan may operate in the form of educational, scientific, or educational and scientific production complexes. In 2010, Tajikistan joined the Bologna process [61]. In 2013, it adopted the regulation on the protection of dissertations for the doctoral degree $(\mathrm{PhD})$, and since January 2015, the dissertation councils have begun their work [62]. Currently, there is a Decree of the Tajikistan Government of November 26, 2016, No. 505 "On approval of the Model Regulations on the dissertation council, the Order of conferring scientific degrees and the award of academic titles (associate professor, professor) and the Order of state registration of protected scientific theses" [63].

However, the prospect of real participation of Tajikistan in the Bologna system is also conditional. The Law of the Republic of Tajikistan of July 22, 2013, No. 1004 "On Education" [64], Article 23 “Documents on education," says "Educational institutions of the Republic of Tajikistan issue the following types of documents to citizens: ... diploma of higher vocational education (bachelor, specialist, master) ...”; however, the status of these titles and the procedure for obtaining them are not regulated by the law, which hinders the possibility of their correlation with international standards.

In July 2014, Tajikistan introduced a single centralized entrance exam with several procedures to ensure fair conduct and assessment at the exam and minimize any interference.

The most successful accession of Tajikistan to the Bologna system is in the direction of a gradual transition of higher educational institutions to the so-called credit education technology using the European ECTS mechanism, when the assessment of student knowledge and competencies is carried out using credit units [65].

\subsection{The Republic of Kyrgyzstan}

Higher education system in the Kyrgyz Republic (Kyrgyzstan) was characterized as having an extensive system of interaction with foreign universities and programs [66]. 
On the one hand, such diversity in the educational opportunities provides benefits to the state focused on education and the creative potential of its citizens due to the limited natural resources; on the other hand, it seems that there are no uniform national standards in this area.

The higher education system in the country is represented by four types of universities: universities, academies, colleges, and institutes. There are 50 higher educational institutions in the country, 34 of which are public [67]. Since the country's independence, the role of private higher educational institutions has consistently increased.

In Kyrgyzstan, a multilevel system of higher and postgraduate education has been developed; it includes a specialty, a bachelor's degree, a master's degree, as well as postgraduate and doctoral studies. Kyrgyzstan chose a strategy of mass higher education as opposed to Tajikistan, which adopted the concept of the elite higher education. The Law of the Kyrgyz Republic of April 30, 2003, No. 92 "On Education" [68] focuses on the social component, the protection of educational and other rights of vulnerable categories of citizens, and the social protection of students.

The highest governmental body of Kyrgyzstan authorized to conduct state policy in the area of higher education is the Ministry of Education and Science of Kyrgyzstan [69]. From 1994 to 2014, licensing and accreditation of universities in Kyrgyzstan was carried out by the State Inspectorate for Licensing and Accreditation of Kyrgyzstan without involving the staff of professional associations [70]. By the Decree of the Kyrgyz Government of June 3, 2014, No. 298 "On the reorganization of the State Inspectorate for Licensing and Accreditation of Educational Institutions under the Ministry of Education and Science of the Kyrgyz Republic" [71], this State Inspectorate was attached to the Ministry of Education and Science.

Since 2012, Kyrgyzstan has moved to a two-tier "Bologna" system of higher education [72].

The National Development Strategy of the Kyrgyz Republic for 2018-2040 "Taza Koom-Jany Door" was approved by the Decree of the Kyrgyz President of November 01, 2018 [73]. It is the main program document determining the strategic directions of the country's development. In terms of education modernization, this document assumes widespread use of digital technologies in education, which should be built in the direction of solving real-life problems and challenges.

In accordance with this, document priorities of scientific activities are determined depending on the country's strategic priorities and the need for innovation.

Research, in turn, should focus on obtaining scientific and practical results. It should be estimates from the point of view of fund use effectiveness and the application of its results.

At the same time, the goal is to further reform the system of awarding scientists and academic degrees, in order to improve the scientific potential of the country and to finalize the system of awarding scientists and academic degrees that meet international standards.

The priority in higher education in the opinion of the developers of the program should be the development of Kyrgyz national education system that is competitive in the international market of services.

Paragraph 3.6 of the Taza Kome-Jany Door strategy is dedicated to the digitization of public administration, including higher education. Its main task, in the opinion of the developers of this Strategy, is to use it as a tool for eradicating corruption in public sector by minimizing the influence of the human factor through the automation of administrative processes and procedures and the provision of digital public services. 


\section{Conclusion}

The integration of higher and postgraduate education systems in the Eurasian space is quite successful. In particular, this concerns a change in the system of assessing students' knowledge, which has become much more variable than the Soviet system. Despite some "minuses" of integration of the educational space within the framework of the "Bologna process," it should be noted that it provided a certain unification of the construction of the educational process. Different "speeds" of this process in the EAEU member states are explained by the need to overcome the existing imbalances in education. The gradual unification of the state regulation of higher and postgraduate education not only provides a freer choice of place of study throughout the EAEU but will also allow to solve emerging problems in a more expeditious manner.

The implementation of Network Universities allows the students to independently form a program of study based on the individual choice of competencies mastered by them. This fact should be positively evaluated.

\section{Author details}

Rashad Kurbanov $^{1 *}$, Ramin Gurbanov ${ }^{2}$ and Asiya Belyalova ${ }^{1}$

1 Institute of Legislation and Comparative Law under the Government of the Russian Federation, Moscow, Russia

2 Plekhanov Russian University of Economics, Moscow, Russia

*Address all correspondence to: mos-ssp@mail.ru

\section{IntechOpen}

(C) 2019 The Author(s). Licensee IntechOpen. This chapter is distributed under the terms of the Creative Commons Attribution License (http://creativecommons.org/licenses/ by/3.0), which permits unrestricted use, distribution, and reproduction in any medium, provided the original work is properly cited. (cc) BY 


\section{References}

[1] Brandenburg U, McCoshan A, Bischof L, Kreft A, Storost Leichsenring U, Neuss F, et al. Advisory Board: Scott $\mathrm{P}$, Uvalić-Trumbić S, de Wit H. Final Report "Delivering Education across Borders in the European Union". Implementing Framework Service Contract EAC 02/2010 (lot 3) And Specific Contract EAC/2012/0152; European Union. 2013

[2] Memorandum of Understanding in these Areas was Signed on May 23, 2007 Between the European Union and the Council of Europe

[3] Schmahl S, Breuer M. The Council of Europe: Its Law and Policies. Oxford: Oxford University Press; 2017

[4] Declaration on the Creation of a Common European Higher Education Area (Bologna Declaration). Russia, Ukraine, Azerbaijan, Moldova, Armenia, Georgia participate in the Council of Europe. Azerbaijan, Georgia, Armenia, Belarus, Moldova, Ukraine take part in the EU Eastern Partnership project. 1999. Available from: https:// web.archive.org/web/20080211212119/ http://www.bologna-bergen2005.no/ Docs/00-Main_doc/990719BOLOGNA_ DECLARATION.PDF

[5] The Convention on the Establishment of the Organization for Economic Cooperation and Development (OECD). 1961

[6] Russian Newspaper (Economic Union). 1999

[7] EURASEC Information Bulletin. No. 3. 2002. pp. $99-100$

[8] Information Bulletin of the Council of Heads of States and the Council of the Heads of Governments of the CIS “Commonwealth", No. 1. 1997

[9] Adopted in St. Petersburg on 16.11.2000 by Resolution No. 27-12 at the 27th plenary meeting of the InterParliamentary Assembly of the CIS Member States. Information Bulletin: Inter-Parliamentary Assembly of the Member States of the Commonwealth of Independent States. No. 39 (part 2). 2007. pp. 103-221

[10] http://continent-online.com/ Document $/$ ?doc_id $=31527146 \#$ pos=0;0

[11] Ionova IA. Setevoy Universitet SNG: Perspektivy dlya VUZov Moldovy. Slavyanskiye chteniya No. 5(11). 2015; Pustovoy NV, Gushchina AM, Nekrasov VV, Tsoy EB. Kontseptsii mezhdunarodnogo setevogo vzaimodeystviya kak instrument podgotovki kadrov vysshey kvalifikatsii (na primere NGTU). No. 2. Universitetskoye upravleniye; 2013

[12] The Official Website of the Eurasian Economic Commission. http://www. eurasiancommission.org/.05.06.2014

[13] Bulletin of International Treaties. No. 11. 2011. pp. 3-5

[14] Appendix to the Decision of the EURASEC Integration Committee. No. 996. 2009. Available from: http:// www.evrazes.com/about/comission/ comission/view/8

[15] Yun SM. Obrazovaniye kak sfera sotrudnichestva $\mathrm{v}$ ramkakh Yevraziyskogo Ekonomicheskogo Soyuza: Problemy i perspektivy. No. 50. Istoriya: Vestnik Tomskogo Gosudarstvennogo Universiteta; 2017. p. 90

[16] Available from: http://www. eau-msu.ru/ckfinder/userfiles/files/ Меморандум\%20текст\%20о\%20 создании\%20ЕСУ.pdf

[17] A Memorandum on Educational and Scientific-Technological Cooperation in the Eurasian Region was Signed. 
Ministry of Education and Science of the Russian Federation. 2016. Available from: http://minobrnauki.rf/news/8152

[18] Petrovskiy P. Tochki rosta YEAES: Ekonomika, bezopasnost', obshchestvo. Yevstaf'yev DG, Kusainov AM, Masaulov SI. i dr.; Rossiyskobelorusskiy ekspertnyy klub, Tsentr izucheniya perspektiv integratsii. 2018. pp. 24-25

[19] Yefremova LI, Fedorov RG. 10 let universitetu Shankhayskoy organizatsii sotrudnichestva: Osnovnyye rezul'taty raboty. No. 4. Vestnik RUDN. Seriya: Vseobshchaya istoriya; 2017. pp. 363-369

[20] BRIKS. Sovmestnaya statisticheskaya publikatsiya, 2015. Braziliya, Rossiya, Indiya, Kitay, YUAR/Rosstat-M.: IITS Statistika Rossii. 2015. p. 235

[21] Letter of the Ministry of Education of the Russian Federation. No. 14-52-988IN/13. 2002. Published in "Consultant Plus"

[22] SZ RF. No. 31, Art. 4398. 2014

[23] Rossiyskaya Gazeta, No. 104. 2018

[24] SZ RF. No. 52, Art. 7477. 2012

[25] SZ RF. No. 20, Art. 2901. 2017

[26] SZ RF, No. 32, Art. 5138. 2017

[27] Kazakhstanskaya Pravda. No. 66-67 (26487-26488). 2011

[28] Presidential Decree. No. 1118. 2010

[29] There is an Indication of the Category "Federal University" or "National Research University" in Art. 24 of the Russian Federal Law "On Education in the Russian Federation"

[30] Collection of Acts of the President and Government of the Republic of Kazakhstan. No. 17, Art. 85. 2016

[31] Collection of Acts of the President and Government of the Republic of Kazakhstan. No. 43-44-45, Art. 236. 2018
[32] Pak N. Integratsiya Respubliki Kazakhstan v mirovoy obrazovatel'nyy stsenariy: ot reform v oblasti obrazovaniya do povysheniya kachestva i obespecheniya uchastiya $\mathrm{v}$ mirovom reytinge. Global Management Journal. 2010;3(2)

[33] Order of the Minister of Education and Science of the Republic of Kazakhstan. On the Recognition of the Accreditation Body and Inclusion in the Register of Recognized Accreditation Bodies (Registry 1) for a Period of Five Years. No. 112; Paragraph IS. 2017

[34] Order of the Acting of the Minister of Education and Science of the Republic of Kazakhstan. On the Formation of the National Registry of Accreditation Bodies of the Ministry of Education and Science of the Republic of Kazakhstan. No. 304; Paragraph IS. 2012

[35] OECD. Review of National Education Policy in Higher Education in Kazakhstan. 2017. p. 90

[36] https://primeminister.kz/rupage/ view/gosudarstvennaya_programma_ digital_kazahsta

[37] OECD. Overview of National Policies for Education Higher Education in Kazakhstan. Available from: http:// www.oecd.org/document/10/0,3343, en_2649_33723_38864842_1_1_ 1_1,00.html

[38] Edvard S, Samvel M, Marine K, Vardan B, Yevgeniy S. Reformy vysshego obrazovaniya kak instrument integratsii $v$ yedinoye yevropeyskoye prostranstvo vysshego obrazovaniya (na primere Rossiysko-Armyanskogo gosudarstvennogo universiteta). Vestnik OmGU. Seriya: Ekonomika. No. 1. 2008. pp. 43-46

[39] http://www.conventions.ru/ view_base.php?id=1599 
[40] Avetisyan PS, Zaslavskaya

MI. Modernizatsiya sistemy vysshego obrazovaniya Armenii v kontekste integratsionnykh protsessov.

Monografiya, Yerevan; 2017. p. 123

[41] Russian-Armenian (Slavonic) University (RAU). Edu Scan. Available from: https://eduscan.net/colleges/rau

[42] Higher Education. Ministry of Education and Science of the Republic of Armenia. Available from: http://edu.am/ index.php/am/documents/index/101

[43] Avetisyan PS, Zaslavskaya MI. Modernizatsiya sistemy vysshego obrazovaniya Armenii v kontekste integratsionnykh protsessov. Monografiya, Yerevan; 2017. p. 136

[44] About the Higher Education in Armenia. Available from: http:// studyinarmenia.org/hea

[45] The National Register of Legal Acts of the Republic of Belarus. No. 13, 2/1795. 2011

[46] Pogorel'skaya AM. Trudnosti sovremennoy sistemy vysshego obrazovaniya v Respublike Belarus'. No. 411. Vestnik Tomskogo Gosudarstvennogo Universiteta; 2016. pp. 116-125. DOI: $10.17223 / 15617793 / 411 / 1763$

[47] The National Register of Legal Acts of the Republic of Belarus. No. 92, 5/34264. 2011

[48] National Legal Internet Portal of the Republic of Belarus. No. 5/42890. 2016

[49] Resolution of the Council of Ministers of the Republic of Belarus. No. 1554. On Approval of the Regulations on the Ministry of Education of the Republic of Belarus. National Register of Legal Acts of the Republic of Belarus. No. 118, 5/9561. 2001

[50] Article 1111 of the Code of the Republic of Belarus "On Education”
[51] Boltochko A. Vyssheye obrazovaniye v Belarusi nuzhdayetsya $v$ reforme. Novaya Eŭropa: informatsionno-analiticheskiy Internet-zhurnal. 2011. Available from: http://n-europe.eu/columns/2011/08/02/ vysshee_obrazovanie_v_belarusi_ nuzhdaetsya_v_reforme

[52] Decree of the President of the Republic of Belarus. On the accession of the Republic of Belarus to the Convention on the recognition of qualifications relating to higher education in the European Region. No. 5. 2002. Available from: http://www.spravka-jurist.com/ base/part-hz/tx_ssslve.htm

[53] Zhuk AI. Vyssheye obrazovaniye Respubliki Belarus' ot Bolonskogo protsessa k yevropeyskomu prostranstvu vysshego obrazovaniya. Vysheyshaya shkola. No. 5. 2010. pp. 3-9

[54] Vetokhin SS. [i dr.]. Bolonskiy protsess kak put' modernizatsii sistemy vysshego obrazovaniya Belarusi. Minsk: Medisont. 2014

[55] Mozheyko V. Dolgiy i slozhnyy put' Belarusi v Bolonskiy protsess: kakim on byl i kuda on nas privel? Diskussionnoanaliticheskoye soobshchestvo. Liberal'nyy klub. 2015. Available from: http://liberalclub.biz/долгий-исложный-путь-беларуси-в-болон/

[56] Pogorel'skaya AM. Vydavaya zhelayemoye za deystvitel'noye, ili vstupleniye Belarusi v Bolonskiy protsess. Vestnik Tomskogo Gosudarstvennogo Universiteta. Istoriya. No. 50. 2017. pp. 69-74

[57] Medium-term development program of Tajikistan for 2016-2020. Approved by the decree of Majlisi namoyandagon Majlisi Oli of the Republic of Tajikistan. No. 678. Centralized Bank of Legal Information of the Republic of Tajikistan GIUP Konuniyat of the Ministry of Justice of the Republic of Tajikistan. 2016. 
Available from: http://www.adlia.tj/ show_doc.fwx?rgn=128392\&conttype $=5$

[58] Akhbori Majlisi Oli of the Republic of Tajikistan, 2013, No. 7, Art. 532; 2014, No. 3, Art. 156, No. 7, part 2 of Art. 422; 2016, No. 3, Art. 1148, No. 7, Art. 624; 2017, No. 7-9, Art. 581

[59] Published in the Official Database. http://base.spinform.ru/show_doc. fwx?rgn $=80240$

[60] Decree of the Government of the Republic of Tajikistan. On the Ministry of Education and Science of the Republic of Tajikistan. No. 145. 2014. Published in the Official Database http://base.spinform.ru/show_doc. fwx?rgn=66731

[61] Tajikistan in numbers. Agency for Statistics under the President of the Republic of Tajikistan. Dushanbe. 2010. Available from: http://www. stat.tj/ru/img/9f5268b192177 e16d1066c1e16aea04a_1287832044.pdf

[62] Rakhmonov AA. Tadzhikistan na puti k globalizatsii obrazovaniya. Materialy XIII mezhdunarodnoy konferentsii 29-31 maya 2015 g. v Leningradskom gosudarstvennom universitete imeni A. S. Pushkina sostoyalas' XIII Mezhdunarodnaya konferentsiya. Obrazovaniye cherez vsyu zhizn': nepreryvnoye obrazovaniye v interesakh ustoychivogo razvitiya. p. 18

[63] Published in the Official Database. http://base.spinform.ru/show_doc. fwx?rgn=91686

[64] Published in the Official Database. http://base.spinform.ru/show_doc. fwx?rgn $=61988$

[65] Fakerov KN, Khabibov SK. Bolonskiy protsess i voprosy vnedreniya mekhanizma vzaimnogo priznaniya kvalifikatsii i dokumentov ob obrazovanii. Vnedreniye ECTS i mekhanizmy priznaniya kvalifikatsii i diplomov. Materialy mezhdunarodnoy konferentsii-Dushanbe. 2006. p. 11

[66] Medushevskiy NA, Shishkina AR. Obrazovatel'nyye sistemy stran Tsentral'noy Azii: vyzovy, riski i perspektivy regional'nogo sotrudnichestva. V kn. Sistemnyy monitoring global'nykh i regional'nykh riskov Grinin L Ye, Sledzevskiy IV, Truyevtsev KM. i dr. Vyp. 5. Volgograd: Uchitel'. 2014. p. 324-325

[67] Tempus Tasis Higher Education in Kyrgyzstan (report). 2010

[68] Vedomosti Zhogorku Kenesh of the Kyrgyz Republic. No. 8, st.323. 2003

[69] "Regulations on the Ministry of Education and Science of the Kyrgyz Republic" (Approved by the Government of the Kyrgyz Republic on February 20, 2012 No. 119). No. 16.

“Erkin-Too". 2012. p. 2166

[70] Abdyzhaparov A. Reforma vysshego obrazovaniya v Kyrgyzstane: Problemy i napravleniya razvitiya. Minsk: GU. BelISA. Available from: http:// belisa.org.by/ru/izd/other/Kadr2007/ kadr07_1.html

[71] Erkin Too. No. 44. 2014

[72] Gyyazov AT, Akhmadzhanov MA. Integratsiya vysshego obrazovaniya Kyrgyzstana v bolonskiy protsess: problemy i perspektivy. Aktual'nyye problemy razvitiya vertikal'noy integratsii sistemy obrazovaniya, nauki i biznesa: ekonomicheskiye, pravovyye i sotsial'nyye aspekty Materialy II Mezhdunarodnoy nauchnoprakticheskoy konferentsii. Izdatel'stvo: Voronezhskiy TSNTI-filial FGBU "REA" Minenergo Rossii. 2014

[73] Erkin Too. No. 91.2018 


\title{
Chapter 4
}

\section{Full Funnel International Enrollment Management}

\author{
Lee Waller and Sharon Waller
}

\begin{abstract}
The article presents the full funnel recruitment model as an alternative to simplistic recruitment models founded only on widening international prospect intake as a means of increasing the recruitment of new students. While increased prospect intake will often increase enrollment outflow, constriction at any point in the funnel holds the potential to negate efforts to increase the number of new international students. The full funnel enrollment management model highlights the importance of maintaining all portions of the intake funnel to ensure the smooth transition of international prospects from initial contact to successful matriculation. Five strategies compose the heart of full funnel enrollment management: (1) outreach, (2) application, (3) advisement, (4) registration and (5) engagement. Each component of the full funnel enrollment management model is examined in detail.
\end{abstract}

Keywords: full funnel, enrollment, management, international, recruitment

\section{Introduction}

The world of student recruitment has forever changed. Success now demands more complex and inclusive planning. Past efforts have long been guided by the concept that expanding the number of applications into the recruitment funnel will ultimately lead to an increase in the number of new student enrollments falling out of the recruitment funnel. While expanded outreach will at times lead to expanded enrollment, the past two to three decades have rocked the world of student recruitment with ever changing and unpredictable results. Outdated and simplistic recruitment strategies have been invalidated in the modern era of globalization. The information explosion brought on by emerging technological advances has increased competition for market share and has forever changed student recruitment [1].

The digital age has engendered an arms race as institutions face challengers to and competition for the recruitment markets they once owned. In the struggle to hold or obtain market share, past approaches are often found wanting. Once solid methodologies are no longer effective and often require extensive broadening and restructuring. That which worked well in the past, likely demands redesign and careful incorporation of wider aspects of student life into the overall process of student recruitment. Successful efforts find it necessary to outstrip competitors and must empower a more complete picture of student engagement and matriculation. The new reality for general student recruitment is exponentially true for international student recruitment. Today's recruiters working the international market find 
themselves in a new era filled with new challenges. These new challenges require new strategies, integrated methodologies, and a broader vision of that which constitutes student recruitment. Success requires that the recruiters of international students must distinguish themselves for the crowd with high quality, integrated services. This is where full funnel enrollment management comes into play.

\subsection{The full funnel approach}

Student recruitment has often been represented by a funnel as a means of illustrating the idea that if more is poured into the funnel more will flow out of the funnel $[2,3]$. The full funnel enrollment management approach acknowledges that the recruitment process involves much more than simple in-flow and outflow of applications magically transforming prospects into students. Full funnel enrollment management recognizes that attracting students to an institution is a very complex process involving a wide-range of precarious interactions. Simply put, restriction in any part of the funnel holds the capability of making increased outreach meaningless. Full funnel enrollment management is very cognizant of this reality and acts accordingly. Where recruitment is concerned, everything matters. The entire flow from initial contact through graduation and involvement in alumni affairs is part of recruitment. Everything must be considered. Nothing can be ignored. Nothing can be taken for granted. Full funnel enrollment management considers the total student experience as part of the recruitment process and assures that every aspect of exposure to the institution is appropriate and well thought out.

\subsection{A stranger in a strange land}

Consider the plight of an international student planning to study in your institution. Have you ever been a stranger in a strange land? What did you need to know? Could you speak the language? Did you need a guide? What were your concerns? Did anyone help you during this time? What were your challenges? How were they overcome?

This international applicant is now a stranger in a strange land. Put yourself in his or her place. Even those daily life routines easily solved by native students may prove ominous and difficult as he or she struggles to learn the basic survival techniques that others take for granted. For example, he or she may have many of the following questions. Where will I live? How do I get a telephone? How do I contact my family? Who do I call if I have an emergency? How do I get around? Where do I buy groceries? How do I get to the grocery store to buy groceries? What will I do on the weekends? What is there to do here? How do I access the money my parents have sent to me? These sorts of questions can yield to even more difficult questions as students face the demands for paperwork and documentation. How do I contact my Embassy? How do I get my visa? How do I get evidence of my past school work? Who is going to help me? The list of potential questions is endless. If you were this student, what would your questions be?

Now consider the plight of a parent who is allowing his or her beloved child to become a stranger in a strange land. Does the institution provide for the care and safety of my child? What does my child do if they get sick? What is your learning environment like? Will my son or daughter have adequate oversight while part of your institution? How will you help my son or daughter survive the transition into your institution? Do these people even care about my child? Again, the list of potential questions is endless. If you were a parent facing the same circumstances, what would you want to know? 
Add to these issues the realization that the identified questions only involve the things that the student and parent know. What about all of the cultural issues and social mores that they do not know? What about the things that they do not even know that they do not know? How will they be helped? Who will help them? What is your plan to guide the student's matriculation into your institution? What is your plan to guide the parent's understanding and utilization of your services? What will you do to keep the student from getting home-sick and wanting to go back home to their family? Though these questions are complex and may never be fully answered, of a certainly, they will not be answered without full consideration of the issues involved. Put yourself in the place of the student and parent. Consider their needs and go to work meeting those needs. Now watch your enrollment numbers climb.

\subsection{The human element}

Begin your journey into full funnel enrollment management by considering the importance of the human element. Is a stranger in a strange land likely to appreciate a friend who shows up to help them? Will that friend be able to gain the strangers confidence and guide the stranger towards successful matriculation? The answers to these questions are most definitely affirmative. A friendly and knowledgeable person in the right place at the right time with the right answers is always a welcome sight. Now consider the expectations of potential students and their parents.

Students love hearing from other students. Parents like meeting administrators and the people in charge of the organization. Students trust other students but may be dubious of the older generation. Parents like other students and other young people; however, they trust those of their own generation. Students want excitement and enthusiasm. Parents want responsibility and accountability.

Students want to hear from athletes, student government personnel, other students, and those their own age. Parents want to hear from Presidents, Provosts, Deans, Directors, and those with authority. Students are seeking colleagues. Parents are seeking accountability. Students are interested in the fun things that are available. Parents seek assurance as to the veracity of the pending financial investment with your institution. Pleasant discourse with a parent is never wasted. Hearing the following from an authority figures might make a difference, "Let me welcome you to XYZ University. We are always delighted to have parents on our campus. Parents pay tuition. Tuition pays our salaries. Remember that all of us work for you, and we are here to help if you need us." While the parent may smile in response to this statement, the message has been conveyed. We care about what you think. We are here to meet your needs. Feel free to ask us for help.

Full funnel enrollment management provides assurance to both parties. Current students and staff members are involved in the recruitment process. Authorities are involved in the recruitment process. Recruitment is everyone's business. Current students and staff members can enthusiastically discuss the awesomeness of campus life. Authorities can thank parents for sharing their son or daughter with the institution and provide a face, name, and contact through which the parent's anxiety can be alleviated. Members of the SGA can talk about activities and student trips. Authorities can provide parents with a coffee cup to let them know that the institution is one of quality and is a great investment in the future of their child.

Whether a current student, staff member or administrator, young or old, always remember to smile. Make a concerted effort to project a pleasant demeanor to everyone at all times. A friendly and helpful persona is essential to assuring those who are strangers in a strange land. The human smile is the greatest form of assurance that could possibly be provide to both students and parents. Likewise, be aware that the first impression is important. No one gets get a second chance to make a 
first impression. Make the most of the opportunity. Recruitment numbers come to those who smile. If you cannot smile or you find the condition worrisome, you are in the wrong profession. Additionally, those that cannot smile have no need to continue through this narrative. For them, the battle is already lost.

\section{Outreach}

Outreach is not something you do. Outreach is who you are. Outreach is a mindset. Outreach is a culture. Outreach is traditional. Outreach is digital. Outreach is innovative and responsive. Outreach is everywhere. Some outreach is organized. Some outreach is spontaneous. Outreach is everyone's responsibility. Let us begin by examining planned outreach. We will then spend some time discussing spontaneous outreach.

\subsection{Planned outreach}

Planned outreach involves organized efforts to recruit international students into your institution. The responsibility for planned outreach is generally assigned to an administrative unit charged with orchestrating efforts and maximizing collaboration between concerned components of the institution in order to increase enrollment numbers. The responsible administrative unit is typically housed in admissions, international partnerships, or an instructional component. The authority hierarchy of the administrative unit may reside at the higher level of a Provost down to the lower level of a recruiter or outreach officer.

These efforts are often operationalized via a formal planning structure to address issues of vision, resources, programs, capacity, brand recognition, competition, and country specific considerations [4]. Planned outreach may include activities that are external and internal to the institution. External activities often include exhibitions, international travel, international student exchanges, recruitment representatives, lead generators, and portal sites, to name a few. Internal recruitment activities may involve strategies associated with social media advertising, student clubs, website design, cultural awareness functions, personnel assignments, volunteer utilization, assigned points of contact, and timely response mechanisms. The list is endless.

While the author firmly endorses comprehensive planning, caution is expressed concerning the danger of planning for 364 days and working 1 day rather than planning for 2 day and working for 364 days. Planning processes are always more solidly embedded in the higher education comfort zone than are strategic interactions with those different from ourselves. For this reason, many enjoy spending all their time in developing plans rather than actually engaging potential applicants down in the trenches. Even with the best strategic action plan brilliantly crafted to promote international enrollment and the most diligent work schedule, one simple question usually determines success, "What sets you apart from the crowd?" More simply worded, "How do you outshine your competitors?" Keep in mind that your competitors are doing all the things that you are doing. They are enacting strategic plans. They are focusing on both external and internal recruitment activities. They are also hard at work. What sets you apart from the crowd? How do you outshine your competitors? What makes you better than them?

The pat answer to these questions is customer service, but the customer service is much more complicated than this simplistic answer implies. You must always keep in mind that your perception of your customer service may not match your customer's perception of your customer service. Additionally, you must also remain 
aware of the 100 to 1 rule for customer service. On average a dissatisfied individual will inform 10 people of their dissatisfaction while 10 satisfied individuals are likely to collectively tell only one person. One hundred satisfied people are required to balance the negative publicity generated by one dissatisfied person. Take a moment and let this sink in. A one-to-one correlation does not exist in regard to offsetting the effects of one dissatisfied individual with one satisfied individual. One hundred satisfied people are required to balance the negative publicity generated by one dissatisfied person. You must solve the problem before it becomes a problem. You must do all in your power to keep anyone from leaving your institution with a negative opinion of your services.

\subsection{Spontaneous outreach}

Friends tell friends. Our global world is intricately connected. A helping hand to a person here may reverberate around the world. This means that all university activities are part of the outreach for international recruitment. All efforts to help one person have the potential to bring another person to enroll in your institution. Ask yourself the following. Are your events designed for international viewing? Do you provide remote access to your events? Does your website accommodate international student and parents? Do you have virtual tours of your campus? Do you provide access to a friendly face for those who just want to ask a question about anything of interest to them? Do you provide access to your student government association? Do you celebrate the success of your international students? Do you maximize your social media sites by providing access to international students and their parents?

Spontaneous outreach is founded on the concept of the extended student. This idea recognizes that a student is more than a student. A student is likely many students. For example, a university may recruit an excellent academic student by providing a merit-based scholarship. This student brings friends, acquaintances, and colleagues to the institution. A student is obviously more than a student. A student should be seen as a gateway to reach many other students.

\subsection{Hosting the applicant's visit to your campus}

One smile properly utilized to the right extended student can be of more effect than a year of planning. One act of kindness can even outweigh a smile. What is your plan to serve your international students and their parents? What provisions do you offer? Some suggestions follow.

Applicants and parents may choose to visit your campus. If so, they will not arrive at your campus from their country. They will likely arrive at the airport then require transportation to your campus. Make certain they get to your campus. Provide easy transportation from the airport. Greet the parents with a smile and a small gift. Be especially certain that the applicant's mother is welcomed. Keep in mind that the mother holds great influence in regard to the family's impression of your institution. The parents and applicant may also require lodging. If you do not have campus lodging available, work with local hotels to offer a standard package at a reasonable cost. Help them with their arrangements. Provide a tour of your local area. Consider providing a broader tour of the region as appropriate. Show them where to buy a pizza and how to go to the mall.

Arrange for your guests to meet some of your student leaders. Be certain to include an administrator. Let them know that you will help the applicant obtain all the services required of normal life in your country such as obtaining a phone, getting to their Embassy, returning to the airport, etc. The applicant and parent will 
understand that many services have an associated cost though you should ensure that the costs are held to a minimum. It is not appropriate to gouge international students. Provide a listing of these courtesy services and associated costs for their utilization.

Share the schedule of available student activities. Ensure that your schedule includes weekend activities so that the student can escape the residence halls for some relaxation. Provide the library hours so that the parents are ensured that study time exists. Remember that while the applicant is interested in activities the parents are interested in the tuition investment. Provide information to meet the expectations of both groups. The applicant and the parents should be orientated as to the dynamics of life in your country. Let both know the ins and outs of what is considered to be acceptable in your culture. Consider providing the international orientation via digital medium as you do not want to focus on the negatives. Keep your personal meetings focused on the positives. Life in your country is good! Your institution is the place to be! Now, smile and treat them in a courteous manner.

Consider implementing an international student adoption program to care for students during the holidays who are not planning on returning home. Holidays are tough times for those separated from their families. You want to help these students overcome their homesickness. Tell the applicant and the parents about this program. Get the parents and the applicant signed up with your social media sites. Make certain that they know whom to contact should they have a concern. Remember that international student recruitment is not something you do. International student recruitment is who you are. Treat the applicant and the parents as you would want to be treated should you be in their place. Be creative and be their friend. My personal favorite is to give the applicant's mother a coffee cup, the applicant a university t-shirt, and the applicant's father the bill for our tuition. I am just kidding about the first two.

\subsection{Remember your influence leaders}

Many institutions utilize representatives to recruit international students though many, many other influence leaders unofficially perform the same task. These are all known as influence leaders. Influence leaders may include governmental agencies, counselors, principals, alumni, parents of other students, and a host of other entities. Indeed, influence leaders are key to success in all recruitment efforts not just international efforts. Influence leaders are entitled to the highest level of customer service. They must be incorporated as part of the team. As part of the team, they are held to the same standards of conduct as other team members. They are, likewise, due prompt consideration of their concerns and quick action on their requests. Every effort must be put forth to keep them in the loop. Strategies must be in place to recognize and share success. What have you done lately to demonstrate your appreciation of your influence leaders?

\section{From initial inquiry through application}

Tracking and follow-up are key to successfully transitioning international inquiries into international enrollments. Since a man was landed on the moon back in 1969, my assumption is that most institutions have the capability to digitally track inquiries from the initial point of contact through to enrollment. Prompt, systematic response to inquiries is critical. If an institution can spend millions on marketing, certainly phones can be answered, response emails can be sent, SMS can be employed, and staff can appropriately reply to applicant requests. If not, please stop here. The battle is lost. Further resistance is futile. Find another occupation. 


\subsection{Power in a name}

Follow up must be personal, courteous and systematic. Applicants like to hear their name. The ancients believed that there was power in a name. The sooner you realize that there is power in a name, the sooner you will reap the rewards brought on by personal contact. "Dear Applicant" is not as powerful as "Dear Lee." "I see that you are an international applicant" does not rival "I see that you are applying from South Africa." Though these responses can be automated, a personal touch is to be preferred. How much of your day does it take to send an individual contact? Why not try a combination of automated and individual?

A personal reply should be sent to an initial inquiry within 24 hours of contact. Inquiries should be followed up once a week until the applicant requests otherwise. At all times, employ all means to talk to all applicants. These prospects have reached out to you. Go out of your way to respond to them. Use email, SMS, phone calls, WhatsApp, LinkedIn, Facebook, Instagram, Snapchat, and every other available means. Track your prospects and respond with a well-designed systematic approach.

\subsection{The levels of contact}

Different levels should be involved in inquiry contact. At times, the Dean should be employed. At other times, the contact should be from staff. Current student participation is appropriate at times. The contact may relate to registration. The contact may share information about a gathering to eat pizza and watch the FIFA cup. Never forget that the parents should also be included in systematic contact. A friend of mine once said of contact, "Men do not buy a shirt every day, but when they do buy a shirt we want them to think of us." International applicants do not enroll in an institution every day, but when they do enroll we want them to enroll with us. The quality of our contacts can make this a reality. Remember that three international contacts gaining three students constitute a far better scenario than 1000 international contacts gaining no international students. Make your efforts personal, courteous and systematic. Your efforts will pay off with increased numbers.

\section{Harness the power of academic advising}

Applicants do not contact an institution because they want to major in admissions. They contact an institution because they are interested in a program of study. International recruitment that ignores contact with program faculty will be limited. Program faculty are your key allies in the recruitment process. They can also constitute a negative factor just as the wrong members in your staff can discourage prospects. Choose your allies wisely. Develop a list of those who will work with you. These are generally the faculty in programs demonstrating healthy enrollments. These programs are healthy for this very reason. The programs are healthy because the program faculty are open to recruiting new applicants and are willing to meet their needs.

\subsection{Academic advising as a recruitment tool}

While academic advising has long been shown to play a major role in student retention [5], academic advisement also plays an import role in student recruitment. Such is particularly true in regard to international recruitment. Academic advising is about building human relationships. Human relationships are at the very heart of 
international recruitment efforts. Your tracking system should be able to gather lists of applicants by program. Introduce the applicant to the program faculty contact. Let the faculty contact know in advance that the applicant has only submitted interest in the program. Let the applicant know that the faculty contact is there to answer their questions if needed. Introduce the applicant's parents to the program faculty contact. Let the faculty contact know in advance that the parents may have questions about the program. Engender dialog. Monitor those faculty program contacts who do not engender dialog and avoid them. In these cases, recruitment staff may seek answers for the applicant and parent. Though every faculty member will not want to participate, those who do will be rewarded with increased enrollment.

\subsection{Set up periodic meeting with academic advisors}

Make every effort to positively reinforce those faculty advisors that actively seek to serve prospective students. Periodic meetings should be held with academic advisors and department heads to keep them informed and hear their concerns. If a concern is voiced, take the concern seriously. Act on it then let the academic advisors know what was done. You may want to give them a personal call to thank them when they have gone out of their way to help a prospect. You may want to provide them a coffee cup or a t-shirt. Sometimes, just a word of appreciation will suffice. Make certain that you take the time to express your gratitude. Faculty are people too. They are very busy teaching and are actively engaged in many activities. While advisement is also part of their job, all people enjoy hearing that they are performing above expectations. You must do your part to support and nurture your good academic advisors. Make a concerted effort to reach out to new members of the faculty. They will appreciate the contact. Engaging and developing academic advisors as recruitment partners will help your international enrollment numbers grow.

\section{The dangerous currents of registration}

For almost all students, navigating registration is the most ominous, frustrating and terror-laden event they will face in their academic careers. Where do they go? Who do they see? How do they get their classes? How will they pay? In 1974, the author stood in line for 2 days to register for classes. The advent of the digital age has changed this scenario and registration is no longer the same. Now many students wait online from 3 days to 4 weeks to complete their registrations. Since mankind was able to land on the moon in 1969, one would suppose that registration has been improved. This supposition may not be correct.

Consider the plight of an international student who is now a stranger in a strange land. While struggling to discover the difficulties of obtaining a phone and learning how to buy groceries, this student must now face the frightful experience of registration. What is to be done? How do we make this experience bearable? How do we get them advised? What about their visa? How do we get them through the gauntlet alive? These are our challenges if we are to grow our international enrollment. We now have the opportunity to become a peer mentor and demonstrate that we are their friends. We are their advocate. At least those of us with increasing international enrollments are their advocates. The remainder is seeking another profession.

\subsection{Hello, I am your peer mentor}

In difficult times, everyone needs a friend. What better friend than a peer to mentor you through the difficult experience of registration? Notice the word, 
peer. While there exists a time and place for potentates and demigods of authority, peers are colleagues. Peers make the journey with you. Peers are there to help you as needed. A peer can assist in navigating the student through the dangerous and threatening landscape of registration. The peer may be a fellow student. A peer may be a staff member from international student affairs. A peer may be a member of the Registrar's team. A peer may be a student ambassador. A peer may be the academic advisor. The peer may be the administrator over all of student services. Or, the peer may be all of the above collaborating to make the registration experience less terrible and more rewarding.

To clear registration, the student must complete their immigration visa. They must be housed. They must be advised. They must be registered into an appropriate schedule of classes. They must pay. To pay, they are to likely transfer of money from another country. What if their credit card encounters difficulty? They may need to interact with their parents. They may need to go to a bank or open an account. Have you mapped out the registration process in order to guide them? Do you know where the bottle necks occur? Do you have a plan for making it through these bottle necks? Have you prepared a team of peer mentors to assist these students in navigating the waters of registration? Do they feel comfortable letting you know that they are encountering problems? Can you smile and be their friend? Or, do you plan to fiddle while Rome burns and seek another occupation? Sometimes other occupations are hard to find.

\subsection{Empower registration as a recruitment tool}

Registrar's often focus on dates, rules, and the limitation of any exceptions. International recruiters recognize that making registration easy for international students increases the university enrollment. When enrollment increases, the university makes more money. Revenue projections are met. People are happy. Accordingly, plans must be made to handle the influx of international students. Keeping them out of lines and the away from the other evils of registration will pay off. Registration must be transformed into a friend. Efforts must be made to register these students as quickly as possible. In the ideal situation, they will be registered before they arrive on campus. In the second-best scenario, they will be registered under the VIP system by their beloved peer mentor. In the worst scenario, they are left to wander the campus to find their own way through the endless lines and across the minefield of despair.

Consider the scenario where the international applicant interfaces with his or her peer mentor. The peer mentor helps the applicant establish contact with his or her academic advisor. The academic advisor visits with the student applicant, shares insight regarding the program of study, and suggests the appropriate schedule for the current semester as outlined in the degree plan. The two then share pleasantries and return to their tasks. At this point, the peer mentor helps the student register, either online or in-person, whichever is necessary. The peer mentor becomes the staff member who guides the student through the process. Classes are entered. A schedule is obtained. The peer mentor ensures that the student has paid his or her tuition and is available if difficulties are encountered. The new international student is shown the location of the classrooms by the peer mentor. The student is prepared for the first day of class. Books are purchased. The library is visited. What if all of this occurred outside the regular registration arena? What if it occurred at the peer mentor's duty station? What if international registration was designed to facilitate the student rather than the needs of the Registrar? Would not that be nice? Why is it not being done? The student will have a good experience. The student will obtain a good schedule. The institution will increase its numbers. More money will be generated. Everyone will be happy. Right? 


\section{Engage students in the university}

Remember that friends tell friends. A student is more than a student. A student extends into myriads of other possible prospects. The recruitment process reaches well beyond the traditional application and admission process. Successful student engagement is also a key component of student recruitment. Why would a student want to join your university unless they have something to do while they are there? On the flip side, with all the wonderful activities that are happening in your institution who would not want to be part of the excitement? Successful international student engagement includes the full utilization of student government, student clubs, student activities, learning resources, residence life, community engagement, career services, and leadership services. To obtain your desired results and achieve positive matriculation of students into campus life consider the following.

\subsection{Plan the new student's arrival on campus}

Even though you may know your way on and off campus, new international students often do not. Put yourself in their place. How do they arrive on campus? Once on campus, where do they go? Who will greet them? Make plans to facilitate their easy transition into campus life. Begin by providing appropriate pre-arrival instructions so that they can find their way onto your campus. Of course, this means that clear instructions must be readily available. Will they be coming from the airport on their own? If so, how will they get to your campus. Will you be providing transport from the airport? If so, how will the student hook up with your representative at the airport? The student cannot be engaged with campus life until the student gets to your campus. Your responsibility is to get the student to campus. Once you get the student on campus, the next objective will be to get the student involved in campus life.

\subsection{Facilitate an easy transition into university life}

You must be proactive in your efforts to matriculate newly arriving international students into campus life. These students require assistance with housing and residence life facilities. This is another occasion to become their beloved mentor and friend. While all institutions have a new student orientation, the needs of new international students differ from the needs of the general student population. New international students require additional information in relation to immigration, cultural norms, health insurance, and a number of other topics [6]. The institution should offer a comprehensive new international student orientation to prepare these students for campus life. They will also need to know about the area and region. Tours should be arranged within the first few weeks to let them know about where they are living and the characteristics of the region. Care should be taken to see that the tours are enjoyable. Nothing is worse than a boring tour. To avoid the latter, involve current international students in the planning as they will plan things that they enjoy. This will ensure that the new international students encounter a meaningful experience and arrive at a similar outcome. Keep in mind that your job is not to tell them what they must not do, your job is to share the good things that they can do while part of your institution's academic family. You are now challenged to be creative in handling the negatives from a positive perspective.

\subsection{Engage a support network}

The two factors of student-to-student interaction and student-to-faculty interaction are well documented as essential to student retention [7]. Likewise, 
these two fundamental factors are also key to international student recruitment. The recruitment model must interface with current students and program faculty. While interaction with faculty members will occur within the instructional model, interaction with other students must be nurtured and developed. There is nothing wrong with hosting academic events for faculty and students as an extension of the academic environment. In fact, such is encouraged. The involvement of current students in recruitment activities is certainly important; however, involvement does not begin or end here. Effort must be made to integrate the new international student into campus life and expand interaction with other students. In fact, this integration must be carefully orchestrated and must guide interaction with the RIGHT students. This can be accomplished via exposure to student government, student clubs, new student activities, and a host of additional planned activities. Matriculation programs can be utilized to provide student ambassadors to guide these efforts. These programs may be funded or non-funded.

\subsection{Involve international students in university events}

New international students require programs to get them out of the residence halls and to engage them in campus life activities. Nothing is more disheartening than sitting in a dorm room with nothing to do. Inactivity often leads to homesickness. Homesick students are more prone to abandon their education and return home to their families. Positive action leads to increased involvement. Increase involvement lead to greater confidence [8]. Greater confidence increases self-worth and enhances the likelihood that the student will make new friends. Participation in campus life activities will also increases the likelihood that the student will make new friends. In short, if students have nothing to do, they will grow discouraged and leave your institution. They will share their experience with others. This will hinder the success of future recruitment activities. If they have something to do, they are more likely to enjoy your institution and to share their experiences with others.

\subsection{Activities by students for students}

Activities should be planned by students for students. Activities should be planned for every weekend though not every student may choose to participate. Activities should enhance the learning experience and provide opportunities to interface with other students. Activities should provide opportunities to interface with faculty and staff. Activities should introduce the student to the treasures of their new life. Activities should deliver on their decision to meet new ideas and encounter new experiences. Their ideas on making your program better should be solicited and followed. Those who listen will increase their enrollment numbers.

\subsection{Practice active advocacy}

When international students encounter problems, advocacy is required. If the problem is not as they think, treat them with dignity and provide an explanation. If the problem is legitimate, do your best to involve them in a solution. Remember that the issue is important to them. They need an advocate. While solving problems is worrisome, your job exists to overcome problems. Become an advocate and help to make their experience a positive one. You will find your role rewarding.

Keep in mind that students are required to succeed in their academic pursuits. Make certain that they are introduced to the full range of academic support services provided by your institution. Introduce them to people. Take them to offices. 
Let them talk to students who have met success while availing these services. These new students must know that pursuit of assistance does not constitute an expression of inadequacy. The library is there for them. Peer tutors will help them. Counseling is available as needed. Disability services are available if required. All are available to help. All they have to do is ask.

Pursuit of these services is a function of student maturity. Celebrate their success with them. Let them know that it is not only acceptable to seek help, it is important for them to take charge of their learning experience. This constitutes academic maturity. You should provide opportunity for mature international students to share their stories with the next generation. You are not the only one that can work as an advocate. Keep in mind that success builds success.

\section{Conclusion}

The implementation of full funnel enrollment management requires the full commitment of every university component to focus on outreach, application, advisement, registration, and engagement. This is especially true for those components related to student services and student success. Full commitment to the provision of coordinated services from initial inquiry to graduation will set your institution above the crowd. With the engagement of your full range of services into the recruitment process, you will outpace your competition and see your international enrollment numbers soar.

\section{Author details}

Lee Waller and Sharon Waller*

American University of Ras Al Khaimah, United Arab Emirates

*Address all correspondence to: sharon.waller@aurak.ac.ae

IntechOpen

(C) 2019 The Author(s). Licensee IntechOpen. This chapter is distributed under the terms of the Creative Commons Attribution License (http://creativecommons.org/licenses/ by/3.0), which permits unrestricted use, distribution, and reproduction in any medium, provided the original work is properly cited. (cc) BY 


\section{References}

[1] Noel-Levitz R. Retooling the Enrollment Funnel: Strategies and Metrics for a New Era. 2009. Available from: https://www. ruffalonl.com/documents/ shared/ Papers_and_Research/2009/ RetoolingTheEnrollmentFunnel0109. pdf [Accessed: 14 July 2018]

[2] Heinz, M. Full Frontal Marketing: How to Embrace Revenue Responsibility \& Increase Marketing's Influence on Pipeline Growth \& Closed Deals [Internet]. 2016. Available from: http:// results.heinzmarketing.com/rs/966VWE-480/images/Heinz-MarketingFull-Funnel-Marketing-ebook.pdf [Accessed: 14 July 2018]

[3] Niles S, Papa J, Cain P. Strategies for Managing Your Enrollment Funnel [Internet]. 2014. Available from https://www.academicimpressions. $\mathrm{com} /$ news/ strategies-managing-yourenrollment-funnel [Accessed: 14 July 2018]

[4] Mayers C. Developing a strategic plan for international student recruitment. 2015. International Education Alliance. Available from: https://services.intead. com/blog/developing-a-strategic-planfor-international-student-recruitment [Accessed: 14 July 2018]

[5] Drake J. The role of academic advising in student retention and persistence. Wiley Online Library. 2011. DOI: 10.1001/abc.20061. Available from: http://advising.arizona.edu/sites/ default/files/jaynearticle\%20(3).pdf [Accessed: 14 July 2018]

[6] Lumadue R, Waller L. Globalization in Education: Assimilating Intercultural Competence. Part 1. Apple iTunes Connect. 2013. Available from https://itunes.apple.com/us/ book/globalization-in-education/ id733811986?mt=11 [Accessed: 14 July 2018]
[7] Heldeman C. Building a Student Retention Program: A Challenge Worth the Effort. 2008. Available: from https:// www.universitybusiness.com/article/ building-student-retention-programchallenge-worth-effort [Accessed: 14 July 2018]

[8] Waller L, Lumadue R. Social Metacognition: Building Self-Worth. Apple iTunes Connect; 2013. Available from https://itunes.apple.com/us/ book/social-metacognition-building/ id733866677?mt=11 [Accessed: 14 July 2018] 



\title{
Chapter 5
}

\section{Lessons from the History of Pedagogical Methods for Culturally Responsive Teaching and Learning}

\author{
Sona Balasanyan
}

\begin{abstract}
The chapter discusses educational practices drawing on examples from the history of pedagogical methods across classic to postmodern realities. It aims at deriving lessons through the exploration of global social contexts of teaching and learning to address diversity and multiculturalism in contemporary education. Accentuating the history of educational practices, pedagogical methods are presented as socially constructed phenomena, while teachers and learners are viewed as possessing socialised knowledge. The chapter concludes with reflections on the pursuit of educational aims as referred to culturally responsive teaching and learning and multiculturalism in contemporary education. It shows that the present world has created diverse forms of pedagogical methods and education is no longer the prerogative of formal education. The teachers and learners are freer from social and physical boundaries. They are more likely to reflect on what they teach and learn. On the other hand, this reflection is hard to achieve in an increasingly entertaining surrounding of new technologies and self-representation. This is one important barrier that teachers and learners have to overcome in order to assure culturally responsive education in the contemporary world. However, they can be more reflexive towards the past in doing so.
\end{abstract}

Keywords: socialised knowledge, history of pedagogical methods, diversity, culturally responsive education

\section{Introduction}

Galileo Galilei was asked by the church to refrain from teaching his ideas, and, as Albert Camus mentions, "Galileo, who held a scientific truth of great importance, abjured it with the greatest ease as soon as it endangered his life" ([1], pp. 1-2). This was a sound example of impossibility of teaching as referred to truths that might not be easily socially accepted or that were not socialised into a given society.

As mentioned by Mangez and colleagues ([2], p. 15), the mandates and professional identities of teachers are historically defined around the twofold task of teaching and socialisation.

In their educational practices, teachers and learners have historically adhered to social opportunities and barriers for education within various social contexts. 
Application of pedagogical methods has been culturally sensitive [3]. However, previously (within the classic and modern realities) schools could count on a number of "certainties" that were "taken for granted" as to, for example, what was to be expected from a "good" pupil or a "good" teacher, while now the normative references are shattered ([2], pp. 2-3). Currently the "socialised knowledge" is complex and dynamic as are the societies where this knowledge originates from.

In the contemporary postmodern world, the push for more culturally responsive education acknowledges that in racially, ethnically, sexually, and religiously diverse societies, teachers can best educate students by appreciation of culturally defined experiences and understandings that students bring with them to schools ([4], p. 27). It is here that historical development of common or shared educational practices through social construction of education becomes important to see the great difficulty of getting agreement as to what may be the moral content of teaching [5].

History of pedagogical methods shows that boundaries of knowing are set within social space and time. Each time teachers and learners engage with pedagogical methods, they maintain or alter their beliefs and accepted ways of knowing.

This chapter argues and shows that knowledge is always socialised and even the most innovative teachers and learners are the bearers of their social realities. Further, the more they are conscious about these realities, the better they can utilise their educational practices. The exploration of social problematics of historically located pedagogical methods means, among other things, to accentuate what are the social opportunities for the utilisation of these methods [12].

The discussion of historicity of educational practices does not claim to be objective or universal in this chapter. It relies on nuanced and well-defended description of possible forms or examples of knowing and knowledge transmission within classic, modern, and postmodern worlds. The chapter offers one way to conceptualise pedagogical methods by presenting a brief social history of educational practices around the world [6] to derive lessons from this exploration for possible cultural responsiveness in contemporary multicultural and diverse educational environments.

The chapter applies the general idea that there is a world of social history of pedagogical methods and education is a historical phenomenon, the ultimate goal of which has been the transmission of culture(s) [7-9].

In the course of the chapter classic, modern and postmodern realities are seen as paradigms indicative for the development of world education. Classic paradigm is characterised by "directness" of world and cultural perceptions, while modern paradigm explicates a scattered reality formed around capitalist or industrial world. Postmodernism is described as an emerging paradigm indicative of world diversity and possible reflexivity towards the variety of past educational experiences $[7,10,11]$.

History of educational practices presented in the chapter is a subjective account of teaching and learning experiences $[12,13]$. It is not meant to be and should not be perceived as comprehensive. It is rather to provoke discussion on possibilities and barriers for educational practices. It is also to illustrate an example of writing a brief social history of educational practices with the aim to derive lessons for present times of education.

\section{Pedagogical methods from classic to postmodern realities}

\subsection{Lessons from the classic world}

Reflections of social scientists on the history of education in classic times frequently refer to geographical locations and ages or epochs: ancient oriental worlds, Ancient Greece, Middle Ages, Renaissance, and Enlightenment ([7], pp. 14-26). 
Ancient Chinese and Indian societies heavily contributed to the construction of education in the oriental worlds. Chinese teachers and learners were described as traditional and disciplined. Chinese education was perceived as "well measured and shaped" ([7], pp. 7-9). The Chinese society recognised three authorities-the emperor (or the governor), the parent, and the teacher. Teaching and learning in this society in classic times would normally take place in a room of an educational house. The walls of the room would be decorated with papers reflecting thoughts of wise men. The classrooms were furnished with small desks and benches for pupils and a larger desk and a tribune for the teacher ([7], p. 9). For the Chinese people, it was essential that a teacher should be strict and pedagogical methods adjusted to this belief. The normative expectation towards a teacher was that he/she should be an authority. The school in classical China would not be open for some hours and would not shut down at all: the schoolchildren would be able to come home early or postpone their class or stay in the educational house as much as they wanted. The learners had flexibility in teaching hours, teaching could take place at every moment whenever the learner wanted, and the reputed teacher, in this case, would have an individual approach towards the learner.

Chinese philosophers, such as Lao Tzu and Confucius, emphasised the role of education and knowledge as utilised within society [13]. Confucius mentioned that knowledge is first congenital and then acquired. The representatives of the Chinese society had respect towards people who they believed were born with innate knowledge. Nevertheless, they valued acquired knowledge more as they knew that knowledge transmitted and received with great difficulty required social efforts. They emphasised the importance of pedagogy as far as it enabled being in a society or possessing social skills, and consequently they devalued lessons that would not be useful for life. A teacher who neglected socially significant knowledge was not respected. Knowing for Chinese people would mean to know things and to act upon these things, to understand socially defined and accepted truths and have own judgments. The nature, individual thinking, and the society were important values on which the educational practices were built. "Shall I teach you what knowledge is? When you know a thing, to hold that you know it; and when you do not know a thing, to allow that you do not know it; - this is knowledge"-said Confucius which is an important call for self-reflection made by a teacher ([14], p. 15).

"Students form a group. They read and repeat letters at loud and write them down on the sand. Two other students write on palm leaves. Another one reads short stories, another one cuts pieces of paper, and a pupil reads the Mahabharata. The teacher occasionally approaches the pupils and answers any questions they may have"-this is a description of an Indian classroom in classic times ([7], p. 11). One can imagine the individual approach of the teacher towards the learners. The school in India was considered to be complete for a pupil when he/she knew writing, reading, and arithmetic. But there was solid groundwork between the instructor and the family of the learner which was indicative of the reputation of the teacher in this society and the closeness of teachers to families.

Through the interdependence of the teacher's and the learner's families, the teacher taught both at the schoolhouse and at the learner's home, which proves the interconnection of the family and education in India. Families invited the teachers to their homes, asking for advice for the child or the learner ([7], pp. 11-12). It is not by chance that the Vedic literature attributed significant importance to teaching being about "sitting next to the teacher". The teacher was seen as a bright man in this society who could discover the truth. Teachers and learners recognised two sources of knowledge-the person and the ultimate foundation of all things.

The Indian society, as a consequence of successful operation of the perceived truth (in its understanding of the essence of things and rational action), considered 
consciousness and knowledge as basic means for transmitting of socially significant knowledge, for recognising what can be learnt as truth. The foundational value for education practices in this society was in the development of individual consciousness as part of the natural whole where this consciousness was contented ([15], p. 26).

The philosophers and teachers in ancient Greece had faith in human resources and saw happiness in the expansion of human capital. Greece, under the domination of the Roman Empire, first embraced the traditions of Sparta's physical education and then the educational developments of Athens ([7], p. 12).

Music was the most popular subject taught in Greece, while in Rome it was not even taught. The Romans considered the priorities of gymnastics as an important subject and were guided by the principle of "multum, non multa" (the principle of "much, not many" education implies that formal education should not merely introduce too many things but should encourage reflection on culture). In the Spartan society, pedagogical methods were fueling the necessity of continuing education, so that the empire would grow its military influence. On the contrary, in Greece they so valued "just thinking" that sophism developed. Socrates saw the way out of sophism through the development of loyalty and self-esteem ([7], pp. 12-13).

It is known that one of the first models of an educational system was proposed by the Greek philosopher Plato. According to him, the purpose of teaching was to create individuals to perform functions that met their specific social status (as defined by the education system) so that the learners would be ready to fulfill their social roles. According to the Platonic testimony of classroom-based teaching, the structure of the society could preserve its quality through education. The education system described by Plato was elite with only two subjects taught by soldiers and philosophers. Those who were prepared to become philosophers were selected from a very young age. Greek philosopher Aristotle thought that pedagogy should be directed towards three basic goals: healing of body and mind and development of consciousness. He identified two groups of subjects: those that prepared the learners for citizenship and those that developed their personality ([7], pp. 12-18).

In the Middle Ages, the world history was closely linked to religion and mostly the spreading of Christianity. Schools and universities were operating within the churches and were scholastic in nature. Pedagogical methods were directed to justify religious beliefs. This is one basic reason why afterwards when the religious and scientific institutions separated [16], the way of thinking that was detached from reality and recognised idols was labeled as "scholastic" ([7], p. 136). In all of the countries of the Middle Ages, public education was seen as a threat to society as the "humble" population (the working class) could turn away from publicly owned work and get resistant; hence, education was not meant for masses. The stream of protest beliefs influenced the adoption and development of mass education only by the end of the fifteenth and the beginning of the sixteenth centuries ([7], pp. 52-53, [16]).

The first university, the University of Bologna, was already established in the eleventh century. Oxford, and Cambridge, Paris and Copenhagen universities were being established and developed from eleventh to fifteenth centuries with major faculties of arts, medicine, law, and theology. In the faculties of arts that later became philosophical, the subjects of grammar, rhetoric, dialectics, arithmetic, geometry, astronomy, and music were thought. These universities were providing elite education of scholastic nature which made them very different from the universities of the nineteenth century $[16,17]$. However, the very establishment of universities was to prove that pedagogy started to concentrate around educational settings (and not within houses or churches as was during classic times).

Three forms of being of the classical societies followed each other: theological, metaphysical, and enlightening. In its theological form, the classical society 
followed polytheism through myths and epics. Then, the scholastic society was concentrated on churches and there was political disobedience [18]. Science and pedagogy before the enlightenment were focused on classifications and dogmas ([11], pp. 14-26). It was the enlightenment era that created the foundations for humanist pedagogy, accentuating critical thinking eventually leading to the split between science and church ([7], p. 27).

Mass demand towards education was growing ([7], pp. 14-26). The world society was entering a new stage shifting from elite education to mass education which was meant to utilise enlightened forms of pedagogical methods.

\subsection{Lessons from the modern world}

Typical pedagogical methods in the industrial age did not follow the ideology of humanist pedagogy. The educators of the time were often described as "state servants"-transmitters of knowledge to strengthen national ideologies [16].

The major influence that the Renaissance and Enlightenment periods had on the formation of modern society was through the principle of natural equality in education and the spread of mass education.

Karl Marx thought that the type of relationship in classic society was "personal dependence." There was a dogma of thinking and behavior. The fact that the upper class had a privileged position in the modern world was an indisputable and unchanging factor. Such ideas typical to, for example, Machiavelli, were unexpected exceptions in terms of knowledge transmitted and received in the modern societies [16]. From Plato's philosophy to the Hegelian historical idealism, educational practices of the classic societies dominated the educational reality. A widespread debate over the issue of education started in the nineteenth century. Providing free and widespread public education in the nineteenth century was the most important issue for the state policy of the civilised countries [7].

In nineteenth-century Germany, with the advent of the Enlightenment, a new type of educational reality emerged, which was characterised as "ignorant" towards the classical dogmatism and a new society, a new mentality of the German Humboldtian education developed. In modern times, education transformed into a social unit whereby the mobility from one social class to another became possible $[7,17,18]$.

Modern societies were very different from classic societies as these were characterised by transitions from one extreme modernist ideological structure to another. Socialist and liberal ideologies were dominating. However, as Toffler said, both socialist and liberalist ideologies were the result of one major capitalist ideology [19].

Did authoritarian forms of sociality collapse in modern society? According to Fromm [19], the social structures of classic society united into one social reality where freedom became "a culture for profit-making". Relying on the Marxian logic, one may conclude that the development of modern society was characterised by the personal independence of teachers driven by their national dependencies. Teaching became a social interaction for raising the price of commodities, qualification of the workforce, and the potential of national capital.

Toffler [20] believed that pedagogical methods of capitalist or modernist societies were directed to preparing learners for factory life. Obviously, the needs of the industrial systems of the modern world were accommodated by the institute of education. Pedagogical methods were designed to teach precision and agility through well-trained mechanical thinking. The state economy was a major value for the modern world. It guided the construction and management of public life through state policies. By the end of the nineteenth century, the appeal of scholars 
against the social system and modern education was growing. Carnegie said that the worst thing that could happen to a nineteenth-century young man was to receive higher education ([21], pp. 187-222). The modern era, and especially the USSR society, formed and developed an educational program that rejected everything unfit for the concept of state ownership (e.g., talent was rejected). One had to constantly live in obedience. A person used to go to kindergarten in the USSR, then become a pioneer, then get higher education (if wanted), but in every educational setting (openly or in a latent form), he/she was trained to be an "exemplary citizen" and, ultimately, a "subject of pride" for his/her society [20].

From the very first steps of the establishment of Soviet education, the idea of forming a "new type of a person/citizen for the nation" was widespread, as a result of which the main focus of pedagogical methods was on public and nonindividual knowledge and the collectivist ethics.

Foucault believed that education in modern societies, through collectivistintellectual thinking and state power, was a superficial means for development, but it was in vain at the individual level, and this was the devastating defect of that education [10].

Mass education, especially in the industrial age, became the basis for the formation of an "educational market" and, albeit serving nationalistic and political ideologies, the number of educational settings worldwide increased. The increase in the number of educational settings would then lead to a new interconnectedness of qualitative social changes. It became publicly accepted that education was a personal need. Individualisation of education and pedagogical methods became more and more important, and the introduction of new means of promoting participation of learners in education was signified. Introduction of new measures to promote participation of learners in educational processes (and the shift from teacher-centered to student-centered pedagogical methods) led to massive changes in educational practiced creating space for application of humanist pedagogy.

\subsection{Lessons from the postmodern world}

Fukuyama noted that the modern age was centered on the ideology of social institutions, and, as a result, societies around the world became either monarchic or fascist or socialist [22]. The modern world was an arena for clashes of ideologies also in pedagogies. In the postmodern world, all social institutions (institutions of education are no exception) have pledged to be liberal-democratic, enabling the formation of new pedagogies for decentralised and global society. Technological advances and information flows created greater complexity in understanding of pedagogical methods and their social environments $[23,24]$.

The main idea behind the postmodern society was and still is diversity [25]. “Let's fight against totalitarianism, let's activate diversity," said Leotard [26]. The modern world came to an end when this claim was publicly and massively legitimised, when society began to be perceived as the society of "posts": "posttotalitarian," "post-authoritarian," "post-international," "postindustrial," etc. Such a change was conditioned by factors external and internal to educational institutions. All of these factors exist in postmodern society to this day, and teaching is different and yet unified across countries and cultures. Popularisation of education is one important feature of postmodern society promoting the emergence of the so-called knowledge society or information society [27-29].

The sharp increase in educational attainment in major countries of the world was the first factor contributing to the change of educational practices from modern to postmodern societies. The need for rapid allocation of educational resources 
emerged. This put emphasis on effective internal management and quality assurance of education which has been attributed to the social demand for teaching and learning. For example, since 1985, educational institutions in the United States have operated towards increase in teaching participation, learning outcomes, assessment of quality of academic programs, quality control with the aim of efficiently allocating human and material resources to educational outcomes. This is a process which, having the same basis of existence but different illustrations, continues to spread all around the world ([21], pp. 187-222). This process increased the power of learners to influence their educational attainment as they began to perceive themselves as decisive subjects for education. Growth in the number of teachers and learners across countries and across educational institutions has led to the perception of teachers and learners as very diverse social groups. This was another factor contributing to the modifications of educational experiences which are to react to the demand for services that would simultaneously accommodate various teachers and learners in different contexts (regardless of their nationality, ethnicity, gender, etc.).

Important characteristics of postmodern pedagogy emerged due to technological advancement. Technologies have been the most important means by which global economic development impacted sectors of societies (also education). Technological development enabled creation of virtual universities/learning environments and distance learning systems, which naturally created a community of teachers and learners unique to the space and time of the postmodern world. Diversity of educational processes increased. Technologies created new opportunities for teachers and learners to collaborate with other social communities and organisations. Increasingly, people gained public understanding of the fact that they are educated at every moment of their lives. Innovative or advanced teaching methods imply education through modifications that address diverse problems in the society, diverse people, and their cultures. At the same time, it is not senseless to suppose that such complex formation of educational practices jeopardised the very predetermination of the ultimate reproduction of socially essential and socialised knowledge since the focus is on the ways of knowledge delivery rather than the knowledge itself.

Baudrillard believed that the postmodern society should be described as a reality of nonmaterialised symbolic meanings attributed to the material world [30, 31]. There is a crisis of authentication; there is no clear distinction between the real reality and the symbolic reality; therefore, there is no reality, and teaching is directed to creation of simulations. Foucault's portrayal of society where there are no ultimate truths seems to be more than applicable in the case of the postmodern world [10]. Everything (also teaching) is uncontrollable but is still perceived as manageable. According to Derrida, the life of postmodern society is a constant self-representation, and the individuals - the teachers, the learners - are passive observers of this representation [32]. They are present at the societies only physically, but their minds are complex "traveling" around the world through the Internet and technologies which have significantly reduced social space and time [20]. This is a society where, according to Derrida, power is subordination, meaning is meaningless, and therefore teaching is nonteaching - pedagogical methods cannot be easily framed or defined [32].

In the postmodern society, the social space is increasingly separated from the physical space and is accelerated in social time. Globalisation is predetermining changes in educational experiences. Educational practices originate in accord to the logic of globalisation and multicultural practices.

Giddens emphasises that in recent human history, mankind and the society are far more close to each other than during other times [23]. From this perspective, social phenomena are reflective projects that are constantly changing and renewable. Teachers are learners which are freer from social and physical boundaries, so 
that they are more likely to reflect on what they teach and learn, but this reflection is harder in an increasingly entertaining surrounding of new technologies.

\section{Conclusions}

Lessons from the classic world showed that the parent and the teacher were respected authorities in the past. The reflection towards thoughts of wise men was accentuated; there was flexibility in teaching hours. The role of education and knowledge as utilised within society, self-reflection, loyalty, and self-esteem of learners was valued by the teachers. Individual approach towards education was accompanied by the closeness of teachers to families and development of learners as citizens. The principle of "much, not many" education implied that formal education should not merely introduce too many things but should encourage reflection on culture.

The modern world legitimised that mobility from one social class to another was possible; however, teaching became a social interaction for raising the price of commodities, qualification of the workforce, and the potential of national capital. Education followed collective ideologies and was in vain at the individual level. As individualisation of education and pedagogical methods became more and more important in the context of legitimised mass education, the introduction of new means of promoting participation of learners in education became important creating grounds for the development of postmodern educational practices.

With postmodernism, pedagogies for decentralised and global society emerged. Technological advances and information flows created greater complexity in understanding of pedagogical methods. Popularisation of education occurred; rapid allocation of educational resources took place. Teachers and learners hence became decisive subjects for education to react to the demand for services that would simultaneously accommodate various teachers and learners in different contexts (regardless of their nationality, ethnicity, gender, etc.). Self-representation became a very important part for applying pedagogical methods.

Lessons from postmodernism showed that pedagogical methods cannot be easily framed or defined; educational practices originate in accord to the logic of globalisation and multicultural practices.

As social phenomena are reflective projects that are constantly changing and renewable, teachers are learners are freer from social and physical boundaries. They are more likely to reflect on what they teach and learn. On the other hand, this reflection is hard to achieve in an increasingly entertaining surrounding of new technologies. This is one important barrier that teachers and learners have to overcome in order to assure culturally sensitive education in the contemporary world. However, they can be more reflexive towards the past in doing so.

The history of educational practices shows that the less the members of the societies perceived each other as teachers and learners on a daily bases, the more likely it was that the social privilege of educational institutions to produce and reproduce socialised knowledge would increase. Public perception of education as a socially inaccessible value emerged in classic times when the public perceived education to occur only within educational settings (as physical space). The society realised the importance of the role of individual teachers in classic and modern worlds.

The more teaching was perceived as relevant to all individuals and to societies in general, the more likely it was that awareness of educational opportunities outside educational settings would increase. Education would then be perceived as social value available to anyone. Educational settings were viewed as one way of getting education, but educational opportunities outside these settings gained significant importance. Every individual started to be seen as a potential teacher and learner. 
The likelihood of the society to be perceived as a "learning or knowledge or information society" increased. This is what happened in the postmodern world.

The analysis presented in this chapter therefore explicated the importance of understanding of educational practices and pedagogical methods associated with social environments, space, and time-the history (and subjective accounts of it). This is to see the societal directives of knowledge production and what educational practices the teachers and learners are likely to perform or may perform.

The present world has created diverse forms of pedagogical methods. Education is no longer the prerogative of formal educational settings. This leaves space for the hypothesis that classic and modern forms of educational practices (concentrated in physical educational settings and on individuals) have been modified. Yet what are the implications of this on individual teachers and learners, and the pedagogical methods these teachers and learners utilise are still a matter of continued research in the historicity of educational practices.

\section{Acknowledgements}

Hovhannes Hindlyan's Collection of Pedagogical Thoughts has been a major source for inspiration for the development of this chapter. This is an Armenian manuscript which has not yet been translated into English. Hovhannes Hindlyan was a nineteenth to twentieth century Armenian thinker who presented a history of pedagogical methods. The idea of writing such a history in this chapter came from his book. He carried out a historical comparative analysis of pedagogical works. As Hindlyan's work has not yet been translated into English, this chapter presents a unique opportunity to get familiarised with some of his insights. Based on his thoughts, this chapter applied the general idea that there is a social history to pedagogical methods that can be subjectively written (rewritten) to inform educational practices.

The open access publication of the chapter became possible through the generous support of Calouste Gulbenkian Foundation.

\section{Author details}

Sona Balasanyan

Faculty of Sociology, Yerevan State University; Caucasus Research Resource

Center-Armenia Foundation, Armenia

*Address all correspondence to: sona@crrc.am; sona.balasanyan@ysu.am

IntechOpen

(C) 2019 The Author(s). Licensee IntechOpen. This chapter is distributed under the terms of the Creative Commons Attribution License (http://creativecommons.org/licenses/ by/3.0), which permits unrestricted use, distribution, and reproduction in any medium, provided the original work is properly cited. (cc) BY 


\section{References}

[1] Camus A. The Myth of Sisyphus. Harmondsworth: Penguin Twentiethcentury Classics; 1975. Print. 192 p

[2] Mangez E et al. Living together in an uncertain world. What role for the school? 2017. 29 p

[3] Berger P, Thomas L. The Social Construction of Reality: A Treatise in the Sociology of Knowledge. Open Road Integrated Media: New York, NY; 1966. $219 \mathrm{p}$

[4] Schettino I, Radvany K, Wells AS. Culturally responsive education under ESSA: A State-by-state snapshot. An ESSA Progress Report. Kappan. 2019;101(2):27-30

[5] Pring R. Personal and Social Education in the Curriculum: Concepts and Content. London: Hodder and Stoughton; $1984.184 \mathrm{p}$

[6] Johannes A, Kortooms M. Phenomenology of time: Edmund Husserl's analysis of time-consciousness. Dortrecht: Kluwer Academic Publishers; 2002. 298 p

[7] Hindlyan H. Collection of Pedagogical Thoughts. Bera: Hakob Matevossian Publishing House; 1901. 240 p. (in Armenian)

[8] Vygotskiĭ L, Rieber R, Carton A, Minick N. The Collected Works of L.S. Vygotsky, Problems of General Psychology: Including the Volume Thinking and Speech. Vol. 1. New York, London: Plenum; 1987

[9] Macdonald P. Phenomenological factors in Vygotsky's mature psychology. History of the Human Sciences. 2000;13(3):69-93

[10] Foucault M. The Order of Things: An Archaeology of the Human Sciences. London: Routledge; 2002. 422 p
[11] Kivisto P, Harman C. Key Ideas in Sociology. Thousand Oaks: California, Sage; 2011. $241 \mathrm{p}$

[12] Crystal D. Postphenomenology and archaeology: Towards a temporal methodology. Time and Mind.

2018;11(3):297-304

[13] Lao Tzu RS. Oxford Essential Quotations. 2014. 364 p

[14] Confucius, Legge J. Confucian Analects, the Great Learning, and the Doctrine of the Mean. New York: Dover Publications; 1971. $151 \mathrm{p}$

[15] Mohanty J. Classical Indian Philosophy. Lanham, MD: Rowman \& Littlefield; 2000.p. 26. 181 p

[16] Bachinin VA. Forty-Three Theses on the Way from Classics to Postmodernism. Vol. 14. SaintPetersburg: Philosophical Society; 2001. pp. 14-26. (in Russian)

[17] De Ridder-Symoens H. A History of the University in Europe: Universities in Early Modern Europe (1500-1800). Cambridge: Cambridge University Press; 2003. $720 \mathrm{p}$

[18] Wilhelm SD, Humboldt V. The theory and practice of self-formation (Bildung) 1791-1810. University of Pennsylvania Press: Journal of the History of Ideas. 1983;44(1):55-73

[19] Toffler A. The Third Wave. London: Collins; $1980.544 \mathrm{p}$

[20] Fromm E. Beyond the Chains of Illusion: My Encounter with Marx and Freud. New York, London: Continuum; 2006. $140 \mathrm{p}$

[21] Meyer J, Ramirez F, Frank D, Schofer E. Higher education as an institution. In: Gumport PJ, editor. Sociology of higher education. 
Baltimore, MD: John Hopkins University

Press; 2007. pp. 187-222. 382 p

[22] Fukuyama F. The End of History and the Last Man. London: Penguin; 1992. $418 \mathrm{p}$

[23] Giddens A. The Constitution of Society: Outline of the Theory of Structuration. Cambridge: University of California Press; 1986. 402 p

[24] Giddens A. Central Problems in Social Theory: Action, Structure and Contradiction in Social Analysis. Berkeley: University of California Press; 1979. $294 \mathrm{p}$

[25] Kemmis S. System and Lifeworld, and the Conditions of Learning in Late Modernity. Curriculum Studies. 1998;6(3):269-305

[26] Bauman Z. Liquid times: Living in an Age of Uncertainty. Cambridge: Polity; 2007. 115 p

[27] Edwards R, Small N, Raggatt P. The Learning Society: Challenges and Trends. London: Routledge; 1996. 302 p

[28] Böhme G, Stehr N. The Knowledge Society: The Growing Impact of Scientific Knowledge on Social Relations. Dordrecht: D. Raeidiel Publishing Conpany; 1986. 209 p

[29] Hassan R. The Information Society. Cambridge: Polity Press; 2008. 266 p

[30] Baudrillard J. Simulacra and Simulation. Michigan: The University of Michigan Press; 1994. 164 p

[31] Baudrillard J. Symbolic Exchange and Death. London: Sage; 1993. 254 p

[32] Derrida J, Caputo JD.

Deconstruction in a Nutshell: A

Conversation with Jacques Derrida. New York: Fordham UP; 1997. 368 p 



\title{
Students and Institutional Preparedness for Educational Encounters: Views of the Margin
}

\author{
Kehdinga George Fomunyam
}

\begin{abstract}
Higher education in South Africa has been plagued by a number of challenges, which different universities have been struggling to handle for the past two decades. Primarily amongst these challenges are student and institutional preparedness for education encounters. The level of preparedness by both the student and the institution determines the kind of educational encounters they have. This chapter explores this phenomenon within a university in South Africa to understand the level of student and institutional preparedness and articulate a pathway for better educational encounters. Designed as a qualitative case study, data was generated using semi-structured interviews and open-ended questionnaires. The data generated was coded and categorised into themes. These themes were social and cultural capital, cognitive skills, educational architecture and institutional culture. These themes revealed that students lack sufficient social and cultural capital needed for knowledge construction in teaching and learning. They also lacked basic cognitive skills required to decipher the knowledge codes within the disciplines which they belong. The findings also reveal that universities lacked a functional institutional culture, which makes for better educational encounters. The educational architecture was also seen as dysfunctional and disenabling as many students found it difficult to navigate their way through it.
\end{abstract}

Keywords: students, universities, preparedness, educational encounters, support

\section{Introduction}

The twenty-first-century higher education landscape in the world in general and in South Africa in particular is a very complex one, plagued by a variety of challenges and opportunities. The level of preparedness by both students and the university determines the kind of educational encounters students will have and how such encounters will shape their educational journeys. Students' preparedness for higher education is seen as one of the main factors affecting first-year attrition or study success. Cloete [1] argues that "from assessments of the South African system by the Harvard panel on Accelerated and Shared Growth Initiative -South Africa, the World Bank and the Centre for Higher Education Trust, South African higher education system could be characterised as low participation with high attrition rates, with insufficient capacity for adequate skills production" (p. 3). This points to the challenges the South African higher education landscape is facing and 
how these have persisted for over 20 years after the end of apartheid. Fomunyam [2] concurs with this by arguing that about 40 percent of students who enter higher education institutions in South Africa end up dropping out and only about 15 percent complete their degree in the minimum completion time. Though the reasons for this vary from context to context, Lemmens [3] argues that the major reason can be attributed to the level of student and institutional preparedness. How prepared both the student and the institution are for the educational encounter is likely to determine the level of student performance in the classroom and the ultimate completion of the programmes.

Monnapula-Mapesela [4] argues that in South Africa, student under-preparedness has become a dominant learning-related cause of the poor performance patterns in higher education. He further states that "surprisingly and of concern, is the fact that still no single university in South Africa, inclusive of those that admit only the cream of the crop, can safely deny students' unpreparedness, high dropout rates, poor throughput, low success rates despite innumerable academic support structures in place, as amongst some of the challenges that confront the country's higher education" ([4], p. 256). Student under-preparedness is therefore a widely recognised issue in South African higher education though the reasons for under-preparedness vary from student to student. The contextual nature of student preparedness in South Africa can be understood as influenced to a greater extent by the political history of the country so that its subtle effects are still being felt within all sectors of education. The fact also remains that the level of social, political and economic capital possessed by different students, which in itself is the result of the socio-economic status of their families, has actually played a major role in the kind of learners being produced and ultimately applying to universities.

Institutional preparedness, as stated above, must also be considered. Manik [5], Cloete [1] and Fomunyam [2] argue that most South African institutions are still grappling with transformation, making them strategically underprepared for the quality of students being ushered into the higher education system. Most universities in South Africa by and large are still being influenced by the culture inherited from apartheid; they fail to attract and retain the best academics and researchers who find more remunerative work elsewhere. Within higher education there is the enormous differentiation between institutions-the abiding differences between historically white universities and historically black universities, and the under-resourced nature of some of these universities makes it increasingly difficult for underprepared students to succeed. Therefore, South African higher education appears caught between the disabling legacies of the past and the structural pressures of the present. The danger is that these twin forces become excuses for inaction-to throw up one's hands and point fingers at apartheid or neoliberalism.

Students' access, preparedness and success are widely debated issues in South African higher education institutions, student under-preparedness being articulated as the dominant learning-related cause of the poor performance patterns in higher education, largely blamed on systemic faults of the school sector ( $\mathrm{Du}[6])$. This level of under-preparedness magnified the widening of access to the larger population, particularly to non-first-language English-speaking students. This is often done with the expectation that universities will intensify support for students in a number of ways, including financial, accommodation, food, health, academic and career advising, life and academic skills and literacies, counselling and performance monitoring, and through referrals to various support programmes [7]. The under-preparedness of the university goes a long way to magnify the underpreparedness of students, thereby creating the perfect ground for poor educational encounters and tensions within the classroom. 
The Council on Higher Education [7] stated that for many South African universities, the dawn of democracy resulted in policy-driven higher numbers of previously disadvantaged students in university studies. In spite of this apparent improvement, enough was not done to ensure the continuous access and subsequent success of these students. Universities are expected to set measures in place which would address the imbalances of the past and ensure that those with limited social, political, economic and cultural capital are empowered enough to co-construct knowledge effectively within the higher education landscape. Roman and Dison [8] arguing in this light point out that universities need to address the "general lack of academic preparedness, multilingual needs in English-medium settings, large class sizes and inadequate curriculum design" (p. 30). The challenge for higher education institutions is not only dealing with the level of preparedness and increasing the diversity of the student population but also involves the provision of quality education. The Council on Higher Education [9] confirms the under-preparedness of universities in South Africa to deal with structural challenges affecting students when it argued that "student experiences posits that the existing cohort of students is not necessarily underprepared, and that failure to succeed lies more in systemic weaknesses in higher education" (p. 10). Therefore, there is a need for universities to fully understand students' thinking to deliver educational practices that will allow them to achieve their full potential while bearing in mind that learning takes place on the basis of social activity.

The Department of Higher Education and Training [10] posits that universities in South Africa are supposed to provide citizens with high-level skills for the labour market, be centres of research excellence, since they are (or are supposed to be) the dominant producers of new knowledge, or find new applications for existing knowledge in order to keep South Africa independent, inventive and able to stave off intellectual subordination to developed, post-industrial countries. The white paper concludes that universities are also supposed to be responsible for social justice and for creating equity and the equitable conditions to reverse the damaging effects of apartheid. The inability of most universities in South Africa as pointed out by Chetty and Pather [11] has resulted in poor throughput rates because institutions are not adequately prepared for its mission or purpose. Student and institutional preparedness must therefore be understood as key drivers of throughput and educational encounters.

Educational encounters within the classroom powered by both student and institutional preparedness determine how students perform in the university. The first-year experience is critical in influencing high dropout rates and low throughput rates. To tackle this challenge, institutions must address and enhance their academic capabilities as universities, and specifically academics, and rigorously conceptualise and design high-quality academic development programmes to support academics and students. However, to understand this complex challenge of student and institutional preparedness, it is critical to look at marginalised students who possess what is needed to succeed within the institution. By exploring their views and those of the academics teaching them, a concrete understanding is what is needed regarding the level of preparedness by both the students and the institution and what can be done to enhance such preparedness to ensure better educational encounters in the classroom. This description of the current situation in South Africa provides the background for this study.

\section{Methodological proclivities}

This research was designed and conducted as a qualitative case study. Fomunyam [12] defines qualitative research as research which seeks not only depth but also the 
complexity of the phenomenon in an attempt to unearth both the particularities and peculiarities ("the what" and "the how") of the phenomenon so as to enhance understanding or develop a theory. In this case, qualitative research sought to explore student and institutional preparedness for educational engagements and encounters. Since the focus of the research was seeking or exploring student and institutional preparedness, the case study approached was engaged. Elman, Gerring and Mahoney [13] argue that case study research explores complex problems whose core is difficult to find or whose root cause is difficult to explain. Explaining such a complex problem, therefore, would require focus on that particular issue and investigation using several instruments or exploring it from different angles. The case study approach offered the opportunity of studying student and institutional preparedness for educational encounters. The case here is the university and the unit of exploration is students and staff. The university under study is a university of technology in the province of KwaZulu-Natal. The high student dropout and low-throughput rates within the university are a direct result of student and institutional preparedness. Most of the students within the university possibly failed to gain admission into other universities before settling for the University of Technology. To generate data from these participants, two approaches were used: the open-ended questionnaire and the interview. The open-ended questionnaire was administered to students, and the interview was done with lecturers. The open-ended questionnaire was administered after 5 weeks of lectures, while the interview was done at the end of the semester creating a space of about 7 weeks in between the interviews. The open-ended questionnaires were administered to students to explore their level of preparedness. Fomunyam [14] argues that open-ended questionnaires consist of openended questions delivered to respondents with the aim of generating a particular kind of information. The open-ended questionnaire gives the participants the opportunity of expressing themselves and providing all the details they think are important. The questions are not limiting in any way. The open-ended questionnaire was administered to first-year students. About 624 first year students from 3 faculties completed the questionnaire. The lecturer's interviews were conducted with the six lecturers (two each from the three faculties) teaching the first-year students. Each interview lasted for 1 hour with the researcher using tape recorders to capture the interview. The researcher obtained permission from the university to conduct the research, and every participant (both the students and the lecturers) understood their participation was voluntary and they could withdraw at any time. The lecturers signed a consent form before the interview was conducted, while the students understood that by completing the questionnaire, they were by default giving consent; those who were uncomfortable participating simply had to refuse filling the questionnaire or fail to return it. The data generated from these two sources were coded and categorised into themes. These themes speak to students and institutional preparedness for educational encounters.

\section{Findings}

The data generated from both the interviews and the open-ended questionnaires were coded and categorised into themes. Two themes, social and cultural capitals and cognitive skills, emerged with regard to student preparedness, while another two themes emerged with regard to institutional preparedness, educational architecture and institutional culture.

\subsection{Social and cultural capitals}

The level of social and cultural capitals a student possesses determines how ready he or she is for educational encounters in the classroom. Since educational encounters 
are built on the basis of this capital, the more a student possesses, the more prepared or ready the student is for educational encounters. One of the participants pointed out that "most of the students lack the experiences and know-how needed to coconstruct knowledge in the classroom. This makes teaching and learning extremely difficult because the teaching has to be the all-knowing in the classroom while students become passive recipients waiting to be filled". Another participant added that "this place is not easy. I was lost the first time I came here I felt like going back home. I was so lost. Cause imagine from primary to high school I have never been in a class with someone who is not Xhosa. And when especially I was interested in other races, whites and, you see I was so I was completely lost. I didn't know what to do, like I just watched them take my bags and I was like yoh I'm not going to cope in this institution. I've never seen it like this, many white and Indian people in my entire life [laughing]. So it was a difficult experience for me. And again had to communicate in English, of which I wasn't used at all speaking English". The feeling of awe in the student puts him in a compromising position in the classroom. Students can barely find their way around understanding the dynamics of the institution and talk less of coming to terms with the racial diversity of the nation amongst other things. These begin to hamper the educational encounters students have in the classroom. The idea of under-preparedness was further supported by another participant who pointed out that "In high school, my teachers would explain some of the things in school when we don't understand what they are saying in English. But here we are taught using English. At times I don't understand half of the things the lecturer is saying. I have to go back and ask my friends. It is too much". Another participant further added that "You know; it's very hard to understand some of this Indian or white people when they speak. And then you speak and don't know some of the words in English. You just stop there of say it in Zulu and they don't understand what you are saying. This has really affected my studies (sighs). I failed four of my test". The lack of social and cultural capitals amongst the students determines the kind of educational encounters they have in the classroom. The lack of capital inhibits their development of commensurate agency which is needed for critical engagement in higher education. The level of student preparedness for educational encounters is a direct function of the capital he or she possesses, and the encounters in turn determine the kind of performance they produce and whether or not they eventually graduate.

\subsection{Cognitive skills}

Skills are vital for every educational endeavour, and it becomes particularly critical in the higher education arena where students are expected to perform a variety of tasks using several cognitive skills. To succeed in the higher education landscape especially for students with low levels of social and cultural capitals, there is a need for a variety of skills like note taking, writing, critical thinking, adaptability, creativity, listening, time management, networking, leadership, presentation and resilience, amongst others. Speaking about the importance of this, one of the participants pointed out that "Some of this students don't even know how to listen in class or take notes. They are distracted for more than half of the class. Some show of very late and hardly ever understand the lesson. At the end when they fail an assignment and you ask them to redo it, some of them just give up or simply want to give up. This makes the chances of their success very slim". Another participant added that "the lectures are too tiring and some of the lecturers just leave you to do all the work. Managing everything is very difficult. I don't have any friends, and I am yet to understand life in this city which very different from where I come from. People here don't care. At times I wake up when the bus for school has left already and I have to wait for the next one which is in two hours maybe and misses my classes. I need help". 
The lack of basic cognitive skills with which to navigate through teaching and learning determines the kind of educational encounters students have in the classroom. Some students lack the skills necessary to make constructive engagements not only with the content being discussed in the class but also outside the classroom. Speaking on this one of the participants pointed out that "the teachers are so fast in ways that I can't hear most of what they are saying. At times I would get notes from my friends and at times they would refused to give or tell me they didn't write. Lecturers want us to do presentations, use computers and power points and stuff. I am still trying to learn those things". A variety of cognitive skills are needed to successfully navigate the higher education landscape. The lack of vital cognitive skills is amongst the reasons for poor educational encounters which make for success in academics.

\subsection{Educational architecture}

The data also revealed that not only are students ill-prepared for educational encounters, but the institution is ill-prepared as well. The data reveal that the university was littered with poor educational architecture which did little to ensure that students got the best educational experience. Such educational architecture informed the kind of educational encounters students had in the class. One of the participants pointed out that "as a lecturer you have about 120 students in a class which is probably supposed to conducively accommodate 80 . It is impossible to engage such a large number of students for a lecture spanning 90 minutes. At the end, the lecturer and one of two students become participants in the knowledge construction process while the others remain passive listeners". Another participant added that "institutional structures are very unfriendly. They just expect you to know everything. They forget you doing this for the first time. You stand in queue for more than two hours just to get a form signed or to pick a group or submit an assignment and stuff. it's very annoying". The educational architecture within the universities determines the kind of experiences students have in the class and the kind of engagements and encounters that ensue. Another participant added that "the classes are not properly ventilated. We almost suffocate in class when it's hot because we are always more than the class can contain and some students are always seating on the floor". Another participant yet added that "the classes and overcrowded and yet there are no microphones in the classroom. The lecturer has to shout and some students are always fidgeting because they trying to ask their friends what is being said. These distractions impact the kind of educational encounters happening in the classroom". If students cannot hear or participate in the knowledge construction process happening in the classroom, then they cannot own the knowledge constructed, meaning no meaningful learning actually takes place. Another participant further added that "the university lack basic educational or teaching and learning facilities like projectors in the classrooms, white boards or responsive boards, enough computers in student's LANs, enough lecturers and administrative staff to handle the student population. For example, some posts have been vacant in this institution for a year, some two years and some even three, all of which are vital positions requiring key personal to hold them". The educational architecture of the institution points to the level of preparedness by the institution for educational encounters in the classroom. Poor planning or preparation leads to poor encounters which hamper throughput rates and cause wanton failure and increases dropout rates.

\subsection{Institutional culture}

Institutional culture influences everything happening in and around the university campus from the way lecturers teach to the way students are welcomed 
and treated and the way they are made to feel within the university. Institutional culture is at the epicentre of higher education and would directly and indirectly influence the educational encounters students have in the classroom as well as determine whether or not the university is ready to receive the diverse student body, which represents the diversity within the nation. Speaking about the culture of the institution and the role it plays in the education of the students, one of the participants pointed out that "the university has a culture of throwing the students into the proverbial deep end to either swim or sink. This is done in a variety of ways, from hiring mentors who themselves lack enough social capital to assist their peers in their educational endeavours, to providing support which addresses the kind of help the university think students need rather than provided targeted support to students when they need them". Another participant pointed out that "there is general culture of resistance to change around the university. The old staff who have been there for years won't give the new and younger staff members the opportunity to innovate. They lord it over them and stifle them to stay within the culture of under-productiveness and conformity to the statuesque”. Though institutional culture cannot be seen, it is experienced all over the university campus. Universities of technology all over South Africa have the culture of focusing more on technical know-how and pattern development rather than research focused on better ways of teaching and learning. This makes teaching and learning unresponsive to the new demands in teaching and learning and the diversity evident in the classroom. Confirming this, one of the participants pointed out that "the way some lecturers were teaching five or ten years ago, is still the same way they are teaching now. There is no difference in their philosophy and the pedagogy. They see all students as the same". Another added that "universities of technologies are often seen as the place for the not so bright who have been rejected by other mainstream universities. As such the problem is the quality of student and no matter what you do, most of them will still fail and drop out. This cultural and capital deficiency approach to viewing students already creates a block in the teaching and learning process because the lecturer can never give their best". Institutional culture therefore presents a significant challenge to the educational encounters happening within the university and by and large shapes the direction of such encounters and how students experience such encounters.

\section{Discussion}

From the findings it is clear that social and cultural capitals, cognitive skills, educational architecture and institutional culture are important factors influencing student and institutional preparedness for educational encounters. Harker, Mahar and Wilkes [15] argue that when students shift or switch from one social field to another (leaving home or local community to the university as is the case with most of the students), they may experience difficulties transferring capitals between fields. This was the case for some of the participants of this study as they strived to develop more capital to tap into in the knowledge construction process. Since capital is the basis of knowledge construction, their ability to construct knowledge is hampered by their inability to develop or possess the right kind of capital. Tzanakis [16] argues that cultural capital is especially transferred by family and education, be it formal or informal, and may be institutionalised or engaged with nominally like group meetings, mentoring programmes, extended programmes and foundation programmes, amongst others. Capital is the primary cause for educational encounters and relative positions within the educational larder. Levina and Arriaga [17] add that cultural capital can exist or be incorporated in three 
forms, the embodied, the objectified and the institutionalised states, of which the objectified and the institutionalised indicate the possession of cultural artefacts and educational credentials. The embodied state is critical to an individual because it involves an ability to decipher the "cultural codes" which are composed of material cultural objects, for example, writings, paintings and monuments. Preparedness for educational encountered for both the student and the institution is hampered by capital. The kind of capital required for the students to construct knowledge is missing, and the cultural codes around the university which makes for its culture and architecture also present a challenge in itself for students and the drive for better educational encounters in the classroom.

Bourdieu [18] expounds on the interconnectedness of culture, architecture and capital in the educational experience by arguing that learning is sponsored by "systems of durable, transposable dispositions, structured structures predisposed to function as structuring structures, that is as principles of generation and structuring of practices and representations which can be objectively 'regulated' and 'regular' without in any way being the product of obedience to rules, objectively adapted to their goals without presupposing a conscious aiming at ends or an express mastery of the operations necessary to attain them and, being all this, collectively orchestrated without being the product of the orchestrating action of a conductor"(p. 72). This means that there are a variety of forces at play influencing educational encounters and institutions and the powers that must take action and responsibility to ensure that these forces are dealt with. The multifaceted nature of the forces at play determine preparedness and how successful or unsuccessful educational encounters are for the students attending the university. The more capital and cognitive skills the student possesses, the more they are predisposed to succeed. Within the context of the findings, it is clear that both the educational architecture and institutional culture of the higher education institutions in South Africa are ill-prepared for educational encounters with students. The right kind of architecture and culture would improve the quality of educational encounters and make for better student performance.

Manik [5] argues that both students and universities are often underprepared for higher education, and universities often need to do more to assist underprepared students as well as transform themselves to become better-prepared institutions so as to foster better educational encounters. Lewin and Mayoyo [19] add to this by arguing there are several factors influencing access and success at university, and these are complex and multidimensional. To them, student preparedness is influenced by schooling background, socio-economic status, race and gender and the social context of learning, student and staff ratio, pedagogy, language and literacy. With the participants articulating these as issues influencing or affecting their educational experience, institutions need to take these factors into consideration if throughput rates must increase, and the educational architecture and the institutional culture must be revisited to pave way for new and better facilities which would ensure that the right kind of educational encounters are garnered. Heymann and Carolissen [20] confirm this when they argue that students must be understood as having "real challenges" and in need of institutional support, but they caution that a patronising attitude should be avoided in classifying students according to categories which will lead to labelling: being "pathologised as problematic" for their specific needs. Sosibo and Katiya [21] further buttress this when they argue that institutions need to provide specialised support especially the acquisition of skills and recognise that students may be struggling with critical skills in English such as speaking, reading and writing. This means that universities need to support students to develop cognitive skills as a way of giving them a wide variety of tools with which to navigate their way in the higher education sector. They continue that 
"under-preparedness refers to the state of students who are in general not academically ready, especially in areas such as reading and writing, and particularly in the language of learning and teaching, which in most cases is English" (p. 274). And this under-preparedness of both students and the university can be improved by considering two key factors which Prinsloo [22] names as timing and appropriateness. In order to be able to provide timeliness and appropriate academic support, institutions need to be able to identify students who need such support at an early stage so as to track and monitor their progress and to evaluate the effectiveness of support systems and programmes offered.

\section{Conclusion}

Student and institutional preparedness for educational encounters is a product of a variety of issues. How these issues are addressed will determine whether or not a student's educational experience improves. From the findings, it is clear that social and cultural capitals, cognitive skills, educational architecture and institutional culture are amongst some of the drivers of educational encounters for students in the classroom. The effects of such encounters are heavily dependent on the levels of preparedness and the drivers that determine such a level. Institutions must therefore recognise the fact that not only are students underprepared but universities themselves are becoming increasingly underprepared as access increases and throughput rates are low. With this in mind, this chapter makes four key recommendations for better educational encounters in the classroom. Firstly, universities need to recognise their capacity and work to improve such capacity in the wake of massification as a way of improving throughput rates especially because they would continuously attract students of similar background or with similar challenges. Secondly, educational encounters are a direct product of work between both the university and students, and specialised support should be tailored and provided to students who need them as a way of empowering them for an improved educational experience. Thirdly, students must strive to improve themselves and garner more capital as they navigate their way through the higher education landscape, for capital is the very currency of educational encounters, and such encounters determine whether or not students succeed and when students succeed. Finally, highereducation stakeholders need to theorise more deeply the ability of higher education institutions to accommodate a certain number of students as well as the ability of certain students to navigate their way through the higher education landscape as a mechanism to ensure that both the institution and the students coming to such institutions are ready for educational encounters in the classroom. This kind of educational encounters is more likely to produce meaningful transformation in both the student and the institution as well as improve throughput rates and guarantee public returns for South Africa's investment in higher education. 


\section{Author details}

Kehdinga George Fomunyam

Teaching and Learning Development Centre, Mangosuthu University of Technology, Durban, South Africa

*Address all correspondence to: kehdinga.george@mut.ac.za

\section{IntechOpen}

(c) 2019 The Author(s). Licensee IntechOpen. This chapter is distributed under the terms of the Creative Commons Attribution License (http://creativecommons.org/licenses/ by/3.0), which permits unrestricted use, distribution, and reproduction in any medium, provided the original work is properly cited. $(\mathrm{cc}) \mathrm{BY}$ 


\section{References}

[1] Cloete N. Free Higher Education: Another Self-Destructive South African Policy. Johannesburg: Centre for Higher Education Trust; 2016

[2] Fomunyam KG. Decolonising the future in the untransformed present in South African higher education. Perspectives in Education. 2017;35(2):168-180. DOI: 10.18820/2519593X/pie.v35i2.13

[3] Lemmens J-C. Students' Readiness for University Education. Pretoria: University of Pretoria; 2010

[4] Monnapula-Mapesela M. Students' perception of own preparedness for higher education: Case Study. International Journal of Educational Sciences. 2015;9(2):255-264

[5] Manik S. Calibrating the barometer: Student access and success in South African public higher education institutions. Alternation. (Special Edition). 2015;17:226-244

[6] Du Plessis L, Gerber D. Academic preparedness of students-an exploratory study. TD: The Journal for Transdisciplinary Research in Southern Africa. 2012;8(1):81-94

[7] Council on Higher education. Report of the Task Team on Undergraduate Curriculum Structure: A Proposal for Undergraduate Curriculum Reform in South Africa: The Case for a Flexible Curriculum Structure. Pretoria: Council on Higher education; 2013

[8] Roman NV, Dison A. Relationship between student preparedness, learning experiences and agency: Perspectives from a South African University. African Journal of Health Professions Education. 2016;8(1):30-32

[9] Council on Higher Education. Access and Throughput in South African
Higher Education: Three Case Studies. Pretoria: Council on Higher Education; 2010

[10] Department of Higher Education and Training. The White Paper on Higher Education. Pretoria: Government Printers; 2013

[11] Chetty R, Pather S. Challenges in higher education in South Africa. In: Condy J, editor. Telling Stories Differently: Engaging 21st Century Students Through Digital Storytelling. Cape Town: Sun Press; 2015

[12] Fomunyam KG. Content and Ideology in Literature Modules Taught in a Cameroonian University. Edgewood: University of KwaZuluNatal; 2015

[13] Elman C, Gerring J, Mahoney J. Case study research: Putting the quant into the qual. Sociological Methods \& Research. 2016;45(3):375-391

[14] Fomunyam KG. Theorising student constructions of quality education in a South African university. Southern African Review of Education. 2016;22(1):46-63

[15] Harker R, Mahar C, Wilkes C. An Introduction to the Work of Pierre Bourdieu: The Practice of Theory. New York: Springer; 2016

[16] Tzanakis M. Bourdieu's social reproduction thesis and the role of cultural capital in educational attainment: A critical review of key empirical studies. Educate . 2011;11(1):76-90

[17] Levina N, Arriaga M. Distinction and status production on user-generated content platforms: Using Bourdieu's theory of cultural production to understand social dynamics in online 
fields. Information Systems Research. 2014;25(3):468-488

[18] Bourdieu P. Outline of a Theory of Practice. Cambridge: Cambridge University Press; 1977

[19] Lewin T, Mayoyo M. Student Access and Success: Issues and Interventions in South African Universities. Cape Town: Inyathelo; 2014

[20] Heymann 1, Carolissen R. The concept of 'First Generation Student' in the literature: Implications for South African higher education. South African Journal of Higher Education. 2011;25(7):1378-1396

[21] Sosibo Z, Katiya M. Closing the loop between access and success: Early identification of at-risk students and monitoring as key strategies used by a South African University. International Journal of Education Sciences.

2015;8(2):271-279

[22] Prinsloo P. Modelling Through-put at UNISA: The Key to the Successful Implementation of ODL. Pretoria: UNISA; 2009 


\title{
Educational Reform in Oman: System and Structural Changes
}

\author{
Ramzi Nasser
}

\begin{abstract}
This chapter gives a historical perspective of the Sultanate of Oman educational developments: system and structural wide changes. The significant and structural changes were on the basis of creating a basic and post-basic education. Structural changes within the Ministry included the establishment of the directories throughout the different states. System wide changes included a complete overhaul of the curriculum leading to a more practice-based and attuned to the work place and pedagogical approaches. The Ministry gave each state in Oman a level of autonomy to its directories. The greatest challenges facing the Ministry of Education and it's reform is bringing the educational outcomes to a level that are benchmarked to international standards and Omani students able to draw on the twenty-first century and technological skills to operate in a globally connected world. The chapter finally concludes on the most pressing challenges to face them and increase student outcomes.
\end{abstract}

Keywords: educational reform, Oman, history of education, basic education post basic education, educational systems, educational structures

\section{Historical background}

Formal education in Oman could be said to have started in the 1930s, under the reign of Sultan Said bin Taimur who is the father of the current Sultan of Oman (Sultan Qaboos); one of the teachers of Sultan Said bin Taimur is known by Sheikh Ahmed bin Sulaiman bin Zahran al-Riyami. He taught the Holy Quran, Arabic and arithmetic, and is known as the "father" of education in Oman [1]. Education was predominantly imputed by the Islamic establishment where religion, Arabic language, and arithmetic were taught in mosques and private homes. One of the first schools in Oman was established in Muscat in 1871 (now the capital of Sultanate of Oman) known by the Al Zawawi School in Al-Khor Mosque next to Al Jalali Fort. The school was run by the Imam of the Mosque, who taught the Holy Quran, the fundamentals of religion, and Arabic language including reading, writing, grammar, and rhetoric. Other well-known schools which opened their doors to Omani students were the Alrahyal School established by Mahnon Ben Alrahyal in Sohar and the Bayada Balrstak mosque and Aldharh School in Bahla and the Alqalah School in Nizwa. Formal education started to take shape [1].

The earliest school was the Masjid Al-Khor in Muscat which opened in 1871 and closed its doors in 1988. There was also Beit Al-Wakeyel School, and the Sheikh Rashid Bin Aziz Alkasibi School was one of the oldest schools that opened in 1888 for government employees. Later in 1914 came the Bothiynah School which 
carried the name after Mohamed Ali Bouzaiene, who came from Tunisia to Oman under the reign of Sultan Said bin Taimur. The school was open for girls and boys and attended in a rented house in Muscat. The school taught the Quran, Arabic language, history, geography, and arithmetic. The school also adopted a study plan that included six classes per day, and its student enrollment did not exceed 120 students; most of the students were accommodated in common and large rooms for males and females [1].

The semi-formal schooling started in the mid-1930s, with the first known by Nader Ben Faisal School which opened its doors in 1932; at the same time, many nonformal schools were opened which taught the Holy Quran, Arabic, and arithmetic. Beginning of the last century, the Al-Saidiyyah School in Muscat opened in 1940 as a semi-public school. The Al-Saidiyyah School included classrooms, administration, and teachers' rooms. It consisted of two stages: the first was a two-year primary school and the second was a six-year primary school. Al-Saidiyyah schools were very popular in which they accommodated for a large student body and had a curriculum attuned with the national educational goals. The school was staffed by teachers from Arab countries and some Omani teachers. The Al-Saidiyyah schools were limited to the study of the Quran and teaching matters of religion, as well as reading, writing, and arithmetic (collection, subtraction, multiplication, and division). The mathematics, science, history, geography, and Arabic language curriculum they used was available from Lebanon. The second and third Al-Saidiyyah schools where in the Muttrah region, administratively located in the Muscat province and Salalah (further point in the south of the country), respectively [2]. The school and its branches continued to grow substantially and developed in 1955, to be able to relocate to its own premises. The large part of schooling was driven by an Islamic educational framework fathered by the likes of Al-Sahabi Al-Jalil Mazin Bin-Ghodouba and Al-Jalandi Bin Masoud-these schools mainly taught the Koran with classical subjects as arithmetic, Arabic, and geography. There were also religious schools in Muscat such as Masjed Al-Khod and Madrasat Al-Zwawiah-both schools taught religion and Arabic [3].

The Al-Saidiyyah School in Muttrah moved to its own building in 1960; in the same year two other third and fourth primary schools were opened. Within 2 years, the primary level was completed until the sixth grade and the graduates obtained the primary certificate. Despite the school's modest and limited resources, they have been credited being citadels of cultural and intellectual movements in the Sultanate and enriching the Omani heritage and culture. The educational development in Oman was centered around population centers with critical masses and mostly around Muscat. Not later than the 1970s had Oman experienced substantive growth in the development of the educational sector with the discovery the oil and gas (which drives the modern day economy). The development was mostly located around the center of commerce of the Muscat region as well as Muttrah which has now the largest sea port in the region [4].

The growth in the educational sector started in 1970 at that time the number of students did not exceed 900 and in mere 5 years there were 207 schools with 55,752 students [5]. In 1986, there were 588 schools and 218,914 students enrolled; at the end of 2015, there were 56,211 teachers and 523,522 students. Till today, Oman had provided free education and encouraged every child to enroll in a school. As of 2017, there were 565,184 students in schools; there were also 1091 schools offering what is currently known as the basic education programs and post-basic education of grade 11 and 12 programs. The school staff serving these schools amounted to $60,165[1,6,7]$. Added to that, the private education sector has also grown tremendously with over 486 private schools in 2015, serving more than 97,465 students [7]. 


\section{Challenges in the educational sector}

The major educational challenges in Oman were several, among the first was the long distances between population densities. The country was geographically spread over thousands of miles apart with two population centers one in the North (Muscat-now capital) and the second in the South (Salalah region, respectively) and small villages spread across Oman's mountainous terrain. It was thus hard to provide the basic infrastructural services as roads and electricity; it was also hard to find the human resources to support teachers and administrators in distant villages. The challenges were concrete and tangible particularly in improving the quality of the teaching and learning process as well as the quality of student outcomes in an information-driven world [8].

Second, with Oman being linguistically, ethnically, and religiously diverse; preservation of tradition, culture and language and concomitantly to move forward in its educational mission in face of a fast changing world was a major challenge. Thus, in unifying the country as an Arab speaking and part of the Islamic world, the reform has stressed and celebrated its cultural heritage, its diverse cultural tradition, religion and languages. Third, on seeing the changes the world has gone through in the last decade, particularly in the integration of technology in education, and the way technology has changed the school, curriculum, or even the delivery of instruction, schools in many parts of Oman were left behind to deal with the technological changes. The reform thus, stressed on modernizing the school infrastructure and technological practices.

Oman's national strategy was to establish a modern society having a solid infrastructure for education and economy, being able to engage with the technological advances in an advanced and technologically driven world. The Ministry of Education also underlined and stressed on the scientific approach in teaching and in the acquisition of knowledge to move society forward, innovate, and reproduce itself scientifically. Thus, education was seen to have a perennial purpose in instilling the intellectual skills and knowledge acquisition of life skills for citizenship and life-long learning. The objective of these strategies was to build a holistic Omani character, able to deal with the current and future challenges, and engage in the making of important-objective and scientific approaches to deal with the modern and the technological age [8].

Fourth, a major challenge facing Omani graduates from secondary schools was their inability to deal with the complexity of everyday life. Thus, this included the ability to analyze and solve problems and being flexible, accommodative, and self-directed [9]. Also, alluding to the work of Wagner, Kegan, Lahey, Lemons, Garnier, Helsing, Howell, and Rasmussen [10], it was suggested the three Rs, rigor, relevance, and respect, were generally missing in Omani schools. Rigor means the ability to do and be able to perform due to their learning, relevance as it relates to what they learn for the future. Respect means the ability to deal with others and adequately respect one another in different context. This has also imputed a new way of thinking and seeing of the new curriculum and how teachers deal with knowledge, the curriculum, and how it is translated to students. It also allowed for the reconceptualization of what school outcomes fit with twenty-first century goals, as to reflect on programs that can prepare students and make them understand the world around them. The impetus also suggested that education is tied to social change, reaching beyond the limits attained by a process in which teachers and students transform their work into productive elements in society and also engage in the social or economic transformation of the nation.

Fifth, Oman like other Gulf states relies heavily on an expatriate work force. With low levels of Omani human capacity, fulfilling jobs in brick and mortar industries, Omanis on a general level have greater reliance on "external-foreign"-cheap 
labor. A national strategy was put in place to train and sustain a large local unskilled labor force [11]. The goals set are still unreachable; challenges abound on the social level. Omanis vie for administrative nontechnical government jobs, and the large private sector shuns Omanis from its workforce. Even many employers feel that students once graduated from school or completed some level of tertiary education lacked "soft skills" and the ability to develop these skills, such as team work, public speaking, problem solving, critical thinking, and a strong work ethic in the public or private sectors [12].

Sixth, while Oman has a large cadre of teachers, many of these teachers according to the World Bank had little training in pedagogical practices. There was also limited practical and applied school training due to a lack of trained trainers. It was also emphasized that teachers were doing significant administrative duties, and added to that, there was increased working hours and a higher number of working days for administrators and teachers [8]. The recent literature specifically by Darling-Hammond [13] suggests that teacher quality is one of the most important factors for student achievement and draws on such factors as teacher training and further professional development. Oman's large teaching-work force reported by the World Bank lack the practical and pedagogical skills needed to operate in modern institutions. Many teachers in the area of expertise have little opportunities to undergo the needed training. There was also a lack of focus on the process of teacher practice, to deal with classroom initiatives and classroom orientations. It was apparent there was a complete alienation between teacher practice, peer activities, and student learning; thus, in many schools in-service training should focus on teaching skills for quality learning [14].

In face of the ever-changing global world, leadership believed that a strategy be in place where technology management, integration, and usage appeared to be a challenge among Omanis as they still abound to compete in a global world. It also appeared that new educational goals prepared Omanis for life and work; the new ecosystem required greater integration of technology in their daily lives. Still, Oman's adaptability was challenged in a rapidly changing technological world and a global world [2].

Lastly, challenges appeared in the preparedness of children entering early-years education. Preschool appeared to be missing and nonexistent especially for the majority of publicly funded schools. It is only recent that early education started taking shape as a precursor to primary education. Also, appetite for investment in private schools and international schools lacked the funding needed to accommodate for the majority of the population as they could not afford school fees [15]. Other important elements were the complete absence of special needs, early childhood education centers, and particularly the establishment of schools for special needs [8].

The challenges were considerable in the trajectory of Oman's development of the educational system which took a great quantitative leap firstly in the development of the educational infrastructure and the second phase, a qualitative impetus, to fit the local and basic education needs of Omani society [9].

\section{The educational reform}

The first reform that took place in Oman was in 1976, during which a development plan emphasized a quantitative increase in infrastructure and teacher development. In 1978, the first white paper underlined the national and global changes, linking education to the development of Omani citizens. More significantly, it stressed on the Omani identity and the ability of the large populace to modernize, 
think rationally and scientifically, be able to assimilate knowledge using modern tools, and acquire the needed thinking skills, as well as become self-effective learners [16]. During the development plan, emphasis was placed on the development of the educational services and the diversification of education by establishing two preparatory schools and professional-technical institutes specialized in technical education to accommodate the intermediate certificate holders. Among these institutes were the Nizwa Agricultural Institute, Teachers Institutes, and the Commercial Secondary School [17]. Initiatives were taken for school improvements in laboratories, resource rooms or workshop facilities, technology and other building amenities. At the same period, the establishment of the first school for people with special needs known by the Al Amal School for the deaf and mentally challenged. Since its inception, Al Amal School reached 309 students in the academic year 2005/2006. The need for such schools remains to be high to this date [18].

The second Five-Year Plan 1981-1985 was a period known by the educational renaissance which continued in two directions: the spread of education through out of Oman and in parallel a qualitative leap in the improvement of the teaching and learning process. The strategy established was to spread education to the remotest areas of the Sultanate and on the other hand, a qualitative initiative that attempted to enrich the schools with the needed services and resources. The creation of the alternative primary schools known by the integrated schools continued to expand creating an integrated curriculum across subjects. The integrated school combined the two stages which supposedly had a purpose to increase the learning process. The preparatory schools were provided with the laboratory, library, and family education room for girls' school. At the same period, the teachers' institutes were established and known mostly as the "intermediate colleges"; the duration of the programs in these college was for 2 years and prepared teachers to practice teaching in schools [19].

In the academic year 1983/1984, the Ministry embarked on opening specialized schools, including the industrial school in Al Batin area which enrolled male students. In the following school year, the "rational school" was opened in Muscat to accommodate students with mental disabilities, rehabilitation, and providing services for students with special needs. In the academic year 1984/1985, the educational system in Oman introduced cycle 1 and cycle 2; added to that, a two-year secondary school comprising of grade 11 and 12. In the year 2001/2002, Omar bin Khatab, a privately funded institute for speech and the blind, opened its doors for students with special needs. The number of students in the academic year 1999/2000 was 11, while in 2006/2007, it reached 115; its growth reflects the greater needs for such institutes in Oman and in the Gulf. Part of the higher education development plans was a number of educational establishments to train in trade, technical, agricultural, and education which included the establishment of the Education, Institute of Justice, Institute of Health Sciences, Institute of Finance, Professional Training Institute, Institute of Public Administration, Oman College of Industrial Arts, and the Police and Internal Security Training Centers [20].

During the period between 1985 and 1990, the scaling of educational infrastructure became more apparent with the growth of the schooling system. In line with national strategic development was promoting principles of quantitative expansion of the education sector, especially in infrastructure projects and programs. During this phase, there was also a scaling up of the educational services and educational infrastructure projects, in parallel to qualitative improvement in the educational processes. Education was seen within the macro-economic scheme, thus linking educational costs to returns in terms of building human capacity. The plan was to support young Omanis to take a greater initiative in seeking the training and eventually provide the supply for the needed human resources to serve the public and 
private-industrial sector with the increase in student enrollment and by encouraging every child to seek an education especially in the remotest areas of the country. It was thus necessary to find some suitable educational outposts in the rural areas of the Sultanate to serve students across Oman. Compounded with the rush to improve teacher quality, the Ministry extended and stressed on the development of education in the Sultanate in terms of quality and quantity, through teacher development and infrastructure of schools, respectively. It also took a challenge where it began to train Omani teachers to obtain the pedagogical skills in subject specialization.

In the academic year 1991/1992, the Ministry made substantial changes to expanding the system and moved to eradicate illiteracy among adults; also the beginning of afternoon schools started the adult education programs. At the same period, the Ministry of Education increased the number of teacher training colleges and other specialized colleges as the Institute of Educational Rehabilitation. The establishment of the teaching colleges allowed Omanis to obtain the pedagogical training having subject specializations to reach teaching qualifications for those whose first degrees were in subject specialization [4].

The period from 1991 to 1995 included infrastructure developments and aimed at continuing the achievement of educational outcomes by balancing between quantity and quality. More accountable measures were in place to balance between spending and the educational returns produced. In the period between 1996 and 2000, Oman set goals to modernize all aspects of Omani life with the desire to achieve self-sufficiency, economic diversification, and sustenance to keep abreast with the global and technological advancement [21].

In the same period between 1991 and 1995, the Ministry of Education had embarked on the establishment of the basic education system which was later implemented in 1998/1999 academic year, which aimed to develop the educational infrastructure to improve the quality and reduce its cost. The Ministry was also able to instill and prepare students to deal with twenty-first century skills, building on soft skills by encouraging the learner to deal with the necessary aspects to better develop the communication skills, self-learning, and the ability to think critically and thus adapt to the latest developments [22]. In the late 1990s and at the beginning of the new century, the implementation of the basic education system came to replace the primary, preparatory, and secondary school; it aimed to develop programs that were centered around twenty-firstst century skills. From 2001 to 2005 , the same level of development and growth continued the previous stage [23]. Specifically, from 2006 to 2010, the period was characterized mostly by scaling the implementation of the basic and post-basic education system. In addition to expanding the application of the latter to all schools, the years 2006-2010 were dedicated to the development of post-basic education in addition to the development and application of the basic education in the lower classes. It became apparent that educational change focused on the content and linked the theoretical applications with practical applications. The approach was also to develop a research initiative allowing greater insight and curriculum revision. It also stressed on the post-basic education system, in line with international experience and benchmarking.

The period between 2010 to the present experienced substantive initiative in the improvement of teaching practices, creation of forums, and teaching collaboratives. Increasingly, schools were given the autonomy to run their own training programs, and this included the development of curriculum, collaborative initiatives that draw on their own capacity of local teacher trainees, and training programs. Many public schools were in line with national and strategic initiatives, an overall initiative stressed on self-sufficiency initiatives with a general aim to sustain Omani teachers and develop effective teacher training programs. A broad aspect of this project was the assessment of school and teachers' needs in the newly educational structure 
established, keeping in mind that few studies or reports have emerged addressing the training programs and the kind of teacher training needed. Nor was there an assessment of the educational facilities, teaching styles, or learning styles within schools. Also, many schools started to share expertise with each other and initiated the collaborative communities between and within schools [24].

At the same period, the Ministry of Education was interested in assessing school supervisors as well as teachers. Assessment took a 360-degree approach in which it covered all aspects of the school system; concurrently, great strides were taken to improve the quality of teachers especially in providing continuous professional development, instilling research capacity and action research as a necessary element for teacher development to improve classroom practices and teaching quality. The Ministry also encouraged schools to improve practices by creating collaborative communities where teachers and staff would share expertise.

\section{Basic and post-basic education}

The reform established the basic and the post-basic education system in 2007/2008. The basic education system extended from grade 1 to 10 . The structure was divided into two cycles; the first cycle consisted of four years (grades 1-4) and cycle two consisted of 6 years (grades 5-10). These two cycles are considered as the basic education; the post-basic education students enter into secondary education made of grades 11 and 12, or otherwise join vocational training institutions. The new post-basic education system organized on a "core plus electives" model for grades 11 and 12 was introduced in 2007. This gradually replaced the existing system of 6 years of primary, 3 years of preparatory, and 3 years of secondary schools, but the range from beginning to completion has remained the same. The basic and guiding principles of the basic education included the stress on structural and system wide changes in the schools as in (1) the development of a philosophy of education; (2) establishment of a set of objectives compatible with student needs; (3) restructuring of the school and educational system through delegation of responsibilities, policies, rules, and regulation; (4) reinforcement of teaching mathematics and science in the English Language; (5) population of students to enter the higher education system; (6) stress on life skills throughout the curriculum;

(7) allow for project-based learning; (8) provide students the autonomy to choose from different courses; (9) development of life skills as needed; (10) creation of teaching strategies and methods that integrate technology; (11) effective professional development for all school staff; (12) continuous infrastructure development in technology; and (13) quality assurance and improvement initiatives.

The foreseen outcomes of the basic education system were to bring the work experience into the educational system. Its intent was to replace expatriate labor force with highly qualified Omani citizens which would have the advanced training before they enter the workplace and thus compete with the large expatriate one. This was also a way to entice and encourage Omanis to have a greater role in the labor market, and in particular emphasize and entice women to take part in the labor market [12]. The other and main focus was on the post-basic education reform which focused on grade 11 and 12. The Ministry of Education attempted to impute the educational process and reinforce the educational reform by stressing on reshaping the last two grades of 11 and 12 of secondary schools. It also attempted to reexamine the content and how it could be translated into practical terms to the lives of students. The stress on the last two grades after the basic education had students relate their education to the real world. The new initiative also stressed on the curriculum and teacher training to emphasize critical thinking, long-life learning, 
citizenship of the world, and global issues, as well as humanity, cultural diversity, instances, and context which make them value the contextual richness. The postbasic framework drew on three important frames in the hope that it reflects on the outcomes that embody the latter dispositions and include the theoretical knowledge, research, community service, and overall excellence.

While the basic and post-basic education system of grade 11 and 12 began in 2007 and scaled to all public schools in Oman, it completed the transformation of all public schools. Couched within new educational philosophies, the Ministry dedicated a large part of its resources to train and retrain teachers and school staff on the curriculum and teacher training [25]. Today, the educational system is well under way and draws on those elements of continuous improvement, benchmarked along international standards allowing for involvement and awareness by the public.

\section{Review of the educational system}

The educational reform that took place in the 1970s, was not evaluated until 1994. The initiative involved a collaboration between the Ministry of Education and the Scottish Qualification Authority, and collaboration between their evaluation summed the educational conditions in Oman. The educational system was traditional, curricula were rather generalized, and education was content-centered as opposed to student centered. Schools and the Ministry lacked a clear vision and mission. Books were outdated, and the educational process was mainly driven by tests and centered around the dense curriculum [25]. Teachers also lacked the skills needed to transform schools into places of learning or made initiatives to face the challenges to advance the needs of the Sultanate of Oman. The initiative envisioned to produce high-quality graduates of general education geared toward skills in problem-solving, critical thinking, and analytical skills [26]. A later study came from the World Bank and the Ministry of Education with two main recommendations in their assessment: creating a culture of excellence and making and developing strong pedagogical skills among teachers [27].

The leadership had also invested interest in education and made great strides in the improvement of quality of education for the development of high-quality human resources imputed by the Oman's economic future in vision 2020 [1]. The Vision 2020 of Oman was a landmark document and provided a frame to move the Omani economy forward. The document also served as a framework of the country's educational system. The Vision 2020 aimed to achieve the status of a "Newly Industrialized Economy,", lowering the disparities between Oman and Oil-rich countries in its surrounding. In vision 2020, Oman attempted to build a solid foundation for human resource development, to offset dependency on Oman's limited oil reserves. The blueprint document was both to move the educational strategy forward among Oman's other economic, social, and human resource developments.

Through the Vision 2020, several educational recommendations were made to the Ministry of Education; among those suggestions was to create a basic education road map that can prepare students to continue their education or join the work force. Mainly the five-year plan between 1996-2000 focused on the development of human capacity [23]. Educational training was one of the key pillars through the improvement of the curriculum that focused on two main aspects. Firstly, the content of the curriculum and secondly, teaching methods. In terms of the curriculum and subject matter, the attempt was to reduce the theoretical parts and connect the material to lives of students and the real world. In addition, teachers were required to align the curriculum to student abilities at each educational phase. Teachers were to reduce the reliance on rote learning and memorization and move 
forward through constructivist approaches with focus on problem-solving, critical thinking skills, and cooperative work, with the assumptions that students were inclined to move away from rote learning and teacher practices centered on classrooms around student initiatives and learning [24]. In parallel to the changes in the system, the initiative was to write a new curriculum supported by teacher guides. The new material was gradually implemented in the schools starting 1998/1999 and continued to date.

The basic education was different from the general education in that it integrated between theory and applications, developing the individual character. The basic education curriculum aimed at providing the learners with the required life skills and preparing them for the work place through life skills, independence, and values embedded in the curricula. Given the challenges of English language proficiency [24] and likewise competencies in mathematics and science, a curricular review was eminent. More so the Ministry was intent on developing a curricula and methods for the two subjects of mathematics and science [25].

\section{Facing the challenges}

A major benchmark in Omani educational history was in 1997 right after the Vision 2020 publication; a clear agenda was put in place which outlined the strategic plan for the next two decades. Its main goals were to equip students with the technological, scientific, and advanced knowledge to move the country's educational system as well as its economic development along twenty-first century skills. The plan was to improve the educational system as a whole which included teacher qualifications, changing the way assessment was performed, closing the afternoon school system and lastly but not least, extending the school day and year.

Significant challenges were seen in how teachers undertook the classroom teaching. Many instructional practices have been pervasive and centered on the traditional rote methods, away from the more substantive and deep approaches to learning. In addition, the alignment of content, sequence, and teacher practices appeared to be unaligned to grade level. While faced with substantive barriers for the improvement of schools, the Ministry of Education has been unable to provide the required resources for the realization of the comprehensive initiatives to improve the quality of education of the required level. But initiatives for improvement has been widespread, this including the process of decentralization as a policy which provided administrative and financial autonomy, giving regional authorities jurisdiction in making administrative and budgetary decisions to state directories. The Ministry of Education lacked the capacity to provide training programs for Omani teachers and management of human resources. Added to the fact that a great number of teachers were migrating from the rural areas to urban areas, leaving many rural schools understaffed [2], it was also not easy to also distribute teachers to all areas and to keep a balance of teachers in rural and urban areas.

System wide changes appeared in the integration of content subject matter, which included the integration bundle subjects as Islamic Studies, Arabic and Social Studies and in another, Mathematics and Science. Each field had the same teacher who teaches the bundle subjects which insured to some extent the integration of the material. Other new subjects were introduced in the curriculum as information technology and environmental life skills. While curriculum changes were done gradually, the adaptation was done in stages. To allow for school staff to deal with the major changes to the curriculum methodology for basic education, the new system was first introduced to 17 schools in the 1998/1999 academic year and 25 schools the next academic year, having been delivered to all schools in 2006/2007. In addition, 
the teaching of mathematics and science in English and teaching of English needed a major overhaul, which suggested these subjects to be more attuned to life and communication skills, public speaking, problem solving, and critical thinking [24].

Another significant change in the system has been the extension of the school year. Oman had one of the lowest numbers of school days when compared to some of the industrialized countries whose students had scored in the upper first quartile in the world on the Trends in International Mathematics and Science Study (TIMSS). Further, many school graduates were challenged by English and had to repeat at least a year of English, mathematics, and information technology to be able to enroll into a regular university program. While several reasons have been attributed to the poor academic outcomes, it was believed that teaching days were lost due to examinations, special events, and other missed holidays. To keep in line with international norms, as an example, Japan (240 days) or Singapore (200 days), extending the school year meant that students would be more at task and would have better performance results. The Ministry decided to extend the school year to 180 days to bring it more into line with hours of schooling in other countries. The school-day increased to 8 periods per day and each period to 40 min per day, which resulted in an overall 60\% increase in hours compared to the old system [2].

English was stressed and started to be taught from grade one of the first cycle. The Ministry also implemented a procedure for curriculum and new teaching approaches, for instance, the teaching of the mother tongue by integrating with other subjects as Islamic studies, geography, and history. It also attempted to adopt international curriculum in the first cycle to keep in par with international benchmarked curriculum. The Ministry of Education also started a comprehensive quality approach to the educational system including the education board (region) and schools. Such approaches included the data-driven performance measure which increased efficacy of decisions along administrative operations. Administratively, three major offices have been established and included the Directorate General of Human Resources Development and Curriculum Evaluation Department and the Directorate General of Planning and Quality Assurance Office all working to support one another in the process of deliberation and evaluation of programs and systems [3].

Other initiatives were made in the improvement of teaching quality, whereby a reconceptualization of the pedagogical approaches was made in the way teachers were asked to give feedback to students and change the way the assessments were applied in the teaching and learning process [28]. The reconceptualization of the pedagogical approaches shifted in the way school instruction could be a predictor of school success. Suggestions were also made in regard to how the assessments were taking place in class. Teachers drew on new concepts of continuous assessment where students could be given continuous feedback in ways to overcome the challenges and provide teachers an understanding of where students could face difficulties in their lessons or concepts. Also, the Ministry of Education and the World Bank suggested that these assessments need also to identify male students to face most of the difficulties because many of them tended to discontinue and dropout from school.

In parallel to system and structural wide improvements made in schools and the Ministry, teacher practice was an important and significant element to the overall improvement of schooling. The preparation institutes were established which gave qualification programs and the start of vocational, industrial, and agricultural schools. The creation of the National Center for Vocational Orientation allowed a different qualification and tracks; it made it permissible for parents to enroll their children and tell parents about available educational and training opportunities. The attempt was to establish a linkage of the general education, university education, and the job market. Within the Ministry of Education, the Department of Schools Performance Development was established for school administrators to 
help them set strategies to reach their targets, apply their plans, and raise capacity among school staff. The department instated regulatory guidelines and policies, thus creating an accountable system for the schools. Another role taken by the latter department has been to train teachers in all facets of basic education. The training assured that basic education program effectively trained in the philosophy, methodology, and curriculum material of the basic education. At the center of the training was the Teacher Training Center in Muscat and later instituted in all the Ministry of Education Directories moved to all out regions in Oman [27].

Teachers Institutes were the only organizations training teachers which later in 1970s became Colleges of Education and integrated in a larger university system, eventually offering a bachelor's degree. The Ministry of Education in fact established the Directory General for Evaluation and Development, and as part of the higher education development, Sultan Qaboos University was established in 1986 with five colleges were established. This included Education and Islamic studies, Agriculture, Sciences, Medicine, Engineering, and Humanities. In addition, there were a number of educational establishments to train in trade, technical, agricultural, and education teacher training, in addition to the Institute of Justice, Institute of Health Sciences, Institute of Finance, Professional Training Institute, Institute of Public Administration, Oman College of Industrial Arts, and Police and Internal Security Training Centers [20]. As with the Sultan Qaboos University, the Ministry of Education made an initiative by drawing upon practices of educational systems as that of the United Kingdom, United States of America, Canada, Australia, and Malaysia, taking into account Omani values and traditions. The intention was to build a citizen whose strong faith in God, loyalty to the nation, is disposed with intellectual, spiritual, emotional, and social qualities amicable with Oman's culture and tradition.

Another step forward was the initiation of the National Forum on the Development of Secondary Education of grade 11-12 held in 2002; it linked closer higher education with the secondary education, and it was apparent with a global world moving to an age of connectedness. Thus, as social systems change all the artifacts around, human functioning and interconnectedness must also change. It is thus within those changes that Oman positioned itself in a global context [29].

\section{The Ministry of Education restructuring}

The Ministry of Education in Oman had administrative and legal jurisdiction of all public schools from grade 1 to grade 12. The Ministry had gone through several restructuring initiatives, the most significant has been the impetus to decentralize the educational system and give autonomy to the directories in the different regions in Oman. The reform was also significant because it drew upon policies which allowed autonomy to the different directories (Ministry of Education Centers) around the country working within a total quality framework and implementing a new curriculum, student assessment, and pedagogical implementation. The directories which spread all over Oman were responsible for evaluating and assessing the educational planning, collecting data from students, teacher training, and the development of the educational sector as well as coordinating with other ministries to address student needs. The central offices in the different regions of Oman were mainly responsible for the implementation of policies established by the Ministry of Education. The different directories within the Ministry of Education also encouraged schools to take up new initiatives and proposals for the improvement of the educational system. The most striking change was to provide teacher autonomy to cover the curriculum with any content they may provide and see fit for the educational purpose of their classes. 
In the past decade (2000 to the present), the Ministry of Education has reoriented its approach in dealing with educational problems and issues through data-driven approach and reliance on empirical evidence and data driven information. Three important initiatives were implemented: (1) provide support to school administrators with important training to develop the educational skills, knowledge, and capacities; (2) the elimination of the two track system (Arts track versus Science track), which came as a result of the study carried out in 1993, to provide equal and equitable opportunities for all; and (3) the implementation of the e-government learning system network, to reach all areas in the Sultanate. The e-government process was appealed as a major tool in the development of public services and in the contribution of the knowledge-based economy, for instance, the development of the educational portal and scaling it to all schools, planned and implemented by 2016 to cover all schools in Oman. The management system, however, has been used only for administrative purposes. More recently, it has extended to reach parents and students, which included data of teachers and administrative staff as well as student's achievement. It had the capabilities to have parents check on their children's work and progress. In addition, the Internet Protocol (IP) was introduced to facilitate the communication between the units of the Ministry and regional educational offices. The intent of the Ministry was to initiate the process to allow the technology to be used by teachers, students, and stakeholders [7].

Future endeavors ensued the development of the creation of interactive electronic curricula of English language from grade one to grade 12 as well as mathematics and science being electronically mediated in Arabic and English. The flagship project was to build a digital model equipped with the latest educational and technological equipment. The Ministry intention was also in its awareness of the technology teachers and school administrators as well as students and parents. The technological endeavor and importance of engaging stakeholders in the educational process are mostly overcoming the digital gap to raise the technological know-how [30].

The Ministry of Education has also stressed on the importance of the private sector and other stakeholders on the improvement and development of the educational program. The Ministry of Education signed a number of partnership agreements with Oman International Bank which financed the printing of textbooks, conferences, and resource centers in schools as the Dawhat Al-Adab General Education School. The partnership between Oman International Bank and the Ministry of Education spearheaded an initiative as part of the social responsibility initiatives that went beyond the concept of commercial sponsorship. It aimed at creating a culture of citizenship where students could experience their responsibilities and prerogatives, thus creating individuals with moral, cultural, and national aspirations that could provide the best of their abilities inside an institution or in the public. Other important players have been the Omantel and Oman Mobile, two telecommunication giants; both companies have made great efforts to provide excellent services to support activities and improve the educational process. Omantel provided the infrastructure resources to establish the Educational Portal project designated for the public schools in Oman, and it also provided a bundle of low price Short Message Service (SMS) to enable parents to keep in touch with schools and be updated continuously with their children's academic performance. In consortium with the latter, the ministry also implanted a number of initiatives in science and mathematics and their interrelation with economy and sustainable social development. Not the least, the ministry also stressed on the significance of data-research-driven policy and that such research is grounded from the field rather from some theoretical and western model. It also appeared that the Ministry made 
substantial effort to draw on the different stakeholders whether the ministries, the public sector, or non-profit organizations. The ministry also stressed on parent involvement and businesses to provide support and involvement in the school [7].

Another important restructuring initiative focused on the assessment and evaluation in the belief that students and teachers, even administrative-staff, have substantive responsibilities including curriculum development and evaluation.

\section{Philosophical position}

The philosophical position of the Ministry of Education was published 1978, in a white paper which tied the educational curriculum to human development, citizenship, and society. Education was seen as couched in strong cultural traditions and Islamic values were thought to build on the Omani character, a character open to society as a whole, able to deal with the technological advances to modernize society. It also stressed on the individual to develop holistically, including physically, intellectually, and spiritually. With overemphasis on the Omani identity extending from its Islamic roots and Arab background, education was also thought to modernize society, especially the technological advancement of society. Four main frames that this philosophy drew upon are (1) teaching couched within a strong cultural tradition and Islamic values; (2) education being able to live within a social and natural world; (3) teaching the individual to learn; and (4) teaching the individual to learn about his identity and citizenship.

The two-cycle structure from grade 1 to grade 10 was believed to improve mathematics, science, English, and computers which were introduced early in the first cycle. The approach was also to allow students within the system and reduce attrition or school leavers. The new structure also helped to rewrite the curriculum and to align the way it was taught. The approach was to rethink the "old" focus on content and curriculum and teaching method centered around student activities in the classroom [31]. The approach was to make the curriculum more engaging to student lives where classroom instruction teachers relied less on rote learning and memorization in their teaching and more effort was given to student-centered activities. No doubt, this has come with new teaching method, using concrete material improved strategies for student assessment and evaluation. Thus, the new curriculum stressed on five main objectives:

1. Developing critical thinking skills

2. Developing problem solving skills

3. Developing collaborative and cooperative work

4. Building positive attitudes of pupils toward their subjects and schooling

\section{Encouraging independence}

The main challenge was to keep pace with the technological change and new educational methods required to prepare Omani children for life and work with new conditions created by the present modern global economy. These required a high degree of adaptability and a strong background in science and mathematics curricula being designed to achieve the knowledge, skills, and attitudes that Omanis will need. 


\subsection{Teaching and learning}

The basic education approach reduced the theoretical and abstract concepts in the curriculum, and through relevance to the material, whether in mathematics and science, there was stress on applications and problem-solving. There was also greater stress on higher-ordered thinking, compatible with ways that assessed individual levels as well as innovative use of technologies. School teachers were drawn to scientific thinking approaches in dealing with knowledge, away from the stress on the subject matter and theoretical component.

Teacher methodologies were also key to the new challenges, while the classroom teaching was assessed to be old and outdated to the knowledge available, classroom environments, and teaching approaches. The new teaching methods shifted from teacher-centered to student-centered where students were given greater responsibility for their own learning. The shift was to move away from a lecture but to organize and simulate activities having relevance to real-life applications. Teachers were encouraged to inform the students of the objectives, what is to be learned and what has been learned. Continuously, teachers discussed with students what they have discovered in the classroom as a group. Further, the structure of the classroom was reorganized to accommodate for group work and collaborative learning.

\subsection{Classroom assessment}

At the juncture of the reform a philosophical turn took place in the conceptualization of how assessment was being used in schools. Philosophically, the assessment was not simply to draw out the mistakes and weaknesses, but also to improve the educational practice and develop the whole educational process, as in providing appropriate classroom environment in which students can successfully demonstrate their abilities across a wide range of skills. To achieve this, the ministry prepared the document underpinning the principles of assessment and evaluation and how to put them in practice through planning, teaching, recording, and reporting. Thus, teachers in the classroom take the responsibility for student assessment, whether in observation performance-based assessment, projects, paper-and-pencils, tests and quizzes, interview and student presentations, and portfolios. Thus, in assessments which are multifaceted, there might be no one way to assess the teachers who were given the opportunity to select their curriculum and to align with their teaching styles.

Assessment started being applied in the teaching learning cycle which stressed on the teaching of students. To measure success, teacher class practices shifted from assessing how much the curriculum has covered to whether students learned and whether the learning was meaningful [18]. This approach also allowed for teachers to know their students and draw on devising curriculum and learning exercise suitable for student ability level, specifically, the new assessment methods: (a) evaluation through the collection of information and student interest in the subject;

(b) planning based on student interest; and (c) teaching based on student interest [32].

Teachers were required to use continuous assessment methods with their pupils and work every day by using assessment instruments such as checklists and recording sheets of student development. Assessments were no more used to see where students are but to see if they could face the challenges and what improvements they could make. Focus of assessment shifted from being seen as end of the course element, but as being part of the educational process where students and teachers can draw on such elements in form of instructional strategies as student oral works, projects, reports, quizzes, short tests, examinations, homework, practical performance, and portfolios. Assessments did not stop there; the ministry wanted 
a 360-degree approach that involved also teachers, administrators, and school staff. In terms of teacher assessment, its use was thought to understand what actions teachers were taking in the classroom. The ministry assigned a four-tear system in which assessors are known as supervisors in the school. The school had established three layers: the first supervisory level was at the school, the second at the state level, and lastly Ministry of Education. The goal of the school assessment was mainly to see whether the national objectives have been achieved and created three layers of checks and balances. The assessment philosophy drew on basically whether students have used knowledge and critical thinking skills that allowed them to move forward in learning [33].

Certainly, teachers were more likely to be effective in their approaches as in doing more critical thinking and problem-solving. Teachers paradigmatically shifted from rote to higher ordered thinking. Teachers were trained to provide more opportunities for classroom activities to take place with students leading the classroom or through active learning opportunities. With that came the change in the assessments inside the class and outside; rather than stress on the final summative assessments, there was greater weightage put on class assignments and continuous assessments with applications to real world problems that integrate technology in the learning and assessments [24].

The assessments were also conceptualized not only to address the learning outcome through the delivered curriculum but were individualized to fulfill the needs of students to address the challenges and strength of each student.

\section{Final remarks and conclusion}

With the speed of the reform, there has been a great impetus to assess whether the changes brought to the educational system was significant to the extent that it provided the needed changes conceptualized by the leadership in Oman. It was important also to address the feedback from stakeholders, the changes, and whether they have materialized into successful outcomes. In 2004, the ministry started to evaluate the new program, and this was done through the different directorships in the different regions. Important challenges were pointed out. First since 1970, great and tremendous infrastructure development was materialized [8]. However, like many Gulf Arab countries (for example Nasser [34]) on International scores as the Trends in International Mathematics and Science Study, Oman had scores below many countries and boys scoring well below girls. School graduates lacked critical skills, particularly in English and other subjects. Thus, for Oman's education system needing to improve, standards needed to be raised.

The establishment of the basic and post-basic education was a significant signpost in the Omani educational reform particularly in structural and system wide changes [35]. The establishment of year 11 and year 12 was a bundle aligned with the curriculum and the workplace, drawing on broader and integrated curriculum with linking learning outcomes to the workplace.

Teachers were trained at writing objectives and aligning to content and learning outcomes. Teachers continued to write objectives in the scope and sequence of the curriculum material. They were required to develop their educational curriculum and activities that suit the environment of the school and change the teaching approach, with greater autonomy given to schools and community of learning [36].

The main challenge facing Oman was a need to keep pace with technological change and new educational methods required to prepare Omani children for life and work in the new conditions created by the present modern global economy. Charged with an appetite for change and high degree of adaptability, Oman thought 
to advance in those critical subject areas as in science and mathematics in order to apply such knowledge and skills to the technology that Oman needs. New and redeveloped science and mathematics curricula and the scientific approaches in school learning were being designed to achieve the knowledge, skills, and attitudes that young Omanis may need to learn and adapt to the very different future they will face. New methods of teaching, using concrete artifacts, improved strategies for student assessment, and evaluation will all be aspects of the curriculum reform. Underlying the educational reform pillars and frame was an integrated development which included physical, intellectual, social, and individual attributes. Thus, the philosophy stressed on the collective formation in line, and compatible with individual needs.

\section{Author details}

Ramzi Nasser

University of Sharjah, Sharjah, United Arab Emirates

*Address all correspondence to: rnasser@sharjah.ac.ae

\section{IntechOpen}

(C) 2019 The Author(s). Licensee IntechOpen. This chapter is distributed under the terms of the Creative Commons Attribution License (http://creativecommons.org/licenses/ by/3.0), which permits unrestricted use, distribution, and reproduction in any medium, provided the original work is properly cited. (cc) BY 


\section{References}

[1] Ministry of Education. A glance at the development of education in Sultanate of Oman. n.d. Available from: http://home.moe.gov.om/ english $/$ module.php? module = pagesshowpage \&CatID $=4 \&$ ID $=7$

[2] Al-Belushi S, Al-Adawi S, Al-Kitani S. Education Reform in the Sultanate of Oman. Unpublished Monograph. Muscat: Ministry of Education; 1999

[3] Ministry of Education. Al-Talim Lal Jamieh Fi Sultanate Oman 1970-2005. Min Al-Intilaq Ila Al-Najah [Education for All in the Sultanate of Oman 19702005. From the start to its success]. Contribution in the 2-year after the UNESCO founding, Sultanate of Oman [in Arabic]. 2006

[4] Al-Nabhani M. Developing the education system in the sultanate of oman through implementing total quality management-The Ministry of Education Central Headquarters-A case study [doctoral dissertation]. University of Glasgow; 2007

[5] Ministry of Higher Education. Book of Statistics 2001-2002. Vol. 4. Muscat: Sultanate of Oman (English and Arabic); 2002

[6] Ministry of Education. The Annual Educational Statistics Book 2014-2105. Muscat: Ministry of Education, Oman; 2015

[7] Ministry of Education. The Annual Educational Statistics Book 2015-2016. Muscat: Ministry of Education; 2016

[8] Ministry of Education and the World Bank. Education in Oman: The drive for Quality. The World Bank; n.d

[9] Sternberg RJ. Beyond IQ: A Triarchic Theory of Human Intelligence. Cambridge, England: Cambridge University Press; 1985
[10] Wagner T, Kegan R, Lahey LL, Lemons RW, Garnier J, Helsing D, et al. Change Leadership: A Practical Guide to Transforming our Schools. John Wiley \& Sons; 2012

[11] Gonzalez G. Facing Human Capital Challenges of the 21st Century: Education and Labor Market Initiatives in Lebanon, Oman, Qatar, and the United Arab Emirates. Vol. 786. Rand Corporation

[12] Al-Busaidi KA. English in the labour market in multilingual Oman with special reference to Omani employees [unpublished doctoral dissertation]. England: University of Exeter; 1995

[13] Darling-Hammond L. Teacher quality and student achievement. Education Policy Analysis Archives. 2000;8(1):1-44

[14] International Council on Education for Teaching. The Sultanate of Oman and a New Educational Reform in Promoting Quality Teacher Education for an Interconnected World. International Yearbook on Teacher Education. Vol. 1. Arlington, VA: ICET; 1998

[15] Al-Lamki SM. The development of private higher education in the Sultanate of Oman: Perception and analysis. International Journal of Private Education. 2006;1(1):54-77

[16] Ministry of Education and UNICEF. Basic Education in the Sultanate of Oman: The Theoretical Framework. Muscat: Sultanate of Oman; 2001

[17] Ministry of Higher Education. Guide to Higher Education Institutes in the Sultanate of Oman. Muscat: Sultanate of Oman (English and Arabic); 2002 
[18] Ministry of Education. Inclusive Education in the Sultanate of Oman: National Report of the Sultanate of Oman. Sultanate of Oman; 2008

[19] Al-Busaidi R, Bashir H.

Development of the colleges of education for teachers in the Sultanate of Oman. International Yearbook on Teacher Education, ICET. 1997;1(2):172-183

[20] The Public News Daily (1987, September 14). Muscat Oman 2311, p.2 UNESCO (1972). Paris: Sultanate of Oman Present Situation of Education; 1972

[21] Dale R, Robertson S. The varying effects of regional organizations as subjects of globalization of education. Comparative Education Review. 2002;46(1):10-36

[22] Alkaaf F, Jindal-Snape D, Roger A. Basic education reform in Oman. International Journal of Academic Research. 2011;3(4):309-314

[23] Ministry of Education. Reform and Development of General Education. Sultanate of Oman; 1995

[24] Al-Jardani K. A study of educational reform \& teacher training in Oman. International Journal of Applied Linguistics \& English Literature. 2012;1(1):64-69

[25] Al Shabibi AS, Silvennoinen $\mathrm{H}$. Challenges in Education System Affecting Teacher Professional Development in Oman. 2017. Available from: https://www.athensjournals.gr/ education/2017-1-X-Y-Al-Shabibi.pdf

[26] Ministry of Education. Bayan Wizarat Al-Tarbiah Wal-Taleem Amam Majlis Al-Shoura. [Ministry of Education Report to the Parliament] [in Arabic]. 2005

[27] Rassekh S. Education as a Motor for Development: Recent Education Reforms in Oman with Particular Reference to the Status of Women and Girls. International Bureau of Education; 2004

[28] Ministry of Education. Educational Development in Malaysia and Oman: Two Success Stories. Sultanate of Oman; 2008

[29] Issan S, Gomaa N. Post basic education reforms in Oman: A case study. Literacy Information and Computer Education Journal. 2010;1(1):19-27

[30] Al-Senaidi S, Lin L, Poirot J. Barriers to adopting technology for teaching and learning in Oman. Computers \& Education. 2009;53(3):575-590

[31] Ministry of Education. Education and Cultural Dialogue in the Sultanate of Oman. Sultanate of Oman; 2009

[32] Al-Dreje M. Tawsif Madkhal Kifayat Fi Al-Amalia Al-Taliemiah [Description of the Basic Competencies in the Educational Process]. The Third Meeting for Educational Evaluation. Directory of Educational Evaluation [in Arabic]. 2016

[33] Earl LM. Assessment as Learning: Using Classroom Assessment to Maximize Learning. Thousand Oaks, CA: Corwin Press; 2003

[34] Nasser R. Qatar's educational reform past and future: Challenges in teacher development. Open Review of Educational Research. 2017;4(1):1-19

[35] Al-Balushi S, Al-Kitani S. The Sultanate of Oman and a new educational reform. Proceedings of the International Council on Education for Teaching, Oman. 1997;44:109-121

[36] Al-Farisiah F. Mashrouh Al-Shabakah Al-Mikroskpia Al-Rakmiah Bi madrasah Al-Wadi Al-Kabir Li-Al-Tileem Al-Aam. The microscopic network project: In Al-Wadi Al-Kabir school of education. Educational Development Journal. 2009;47:6-8 [in Arabic] 


\title{
Analysis of Academic Achievement in Higher-Middle Education in Mexico through Data Clustering Methods
}

\author{
Guillermo Molero-Castillo, Everardo Bárcenas, \\ Alejandro Velázquez-Mena and Yaimara Céspedes-González
}

\begin{abstract}
In recent years, there is a natural need to look for new ways to analyze and process data from different sources. One of these ways is through data analysis methods. Thus, given the importance of making academic diagnoses, this paper presents the academic achievement analysis, in Language and Communication and Mathematics, of students from autonomous, public and private schools of HigherMiddle Education in Mexico through data analysis methods. Data analyzed were registers of the National Plan for the Evaluation of Learning, which puts into operation the National Institute for the Evaluation of Education in coordination with the Secretariat of Public Education, Mexico. A variety of academic achievements was observed, highlighting Insufficient and Elementary in the evaluated population, while a small number reached acceptable achievements, that is, Satisfactory and Outstanding. This contrasts a notable difference between the levels reached by students, which leads them to delay or stop their university studies because they obtain a completion certificate of studies without having the necessary knowledge to pass the entrance examination in the universities.
\end{abstract}

Keywords: academic achievement, data analysis, higher-middle education, PLANEA, secretariat of public education

\section{Introduction}

Nowadays, education is one of the key pillars for the social and economic development of a country. Students who currently attend compulsory education, such as primary, secondary and higher-middle school, in future will be responsible for becoming the labor and economic force of a region and, therefore, of a country [1]. However, in order to obtain satisfactory results, quality education is needed; which is achieved through educational systems that have a decisive role in the improvement of educational quality [2]. An educational system could be made up of the academic training of teachers, the educational contents found in the plans and study programs, and the daily life of schools. 
Thus, as academic achievement is an important measurement parameter on the education quality, provided by educational systems, there is a need to know to what extent students achieve essential learning in different domains at the end of each educational level, with the purpose of making a diagnosis of the performance and knowledge achieved by students. In the specific case of Higher-Middle Education, according to [3], there are cases of students who at the end of their studies obtain the completion certificate without having the minimum knowledge necessary to subsequently pass the entrance exams in universities of the country; bringing as a consequence that they delay or stop their university studies.

Given this, make diagnoses about the necessary knowledge acquired by students in school age is important because through these could be articulated strategies to improve the academic level and ensure homogeneous conditions to students for the continuation of a career university [4]. Precisely, currently, one of these diagnoses is made through the National Plan for the Evaluation of Learning (PLANEA, for its acronym in Spanish) in Higher-Middle Education, which puts into operation the National Institute for the Evaluation of Education (INEE, for its acronym in Spanish) in coordination with the Secretariat of Public Education (SEP, for its acronym in Spanish) of Mexico. PLANEA has as its main purpose to know the extent to which students manage to master a set of essential subjects at different times of their compulsory education [5]. In addition, the results offered by PLANEA aim to improve education based on the following actions $[4,6]$ :

- Inform society about the educational level in terms of student learning.

- Provide information of interest to educational authorities for the planning, programming, monitoring, and operation of the education system.

- Offer information to schools to help improve teaching and learning practices.

On the other hand, at present, due to the growth of data collection and the evolution of computing power, information is stored in different sources. This allows for using historical data to explain the past, understand the present and predict future situations [1]. Therefore, there is an increasing need to look for new ways to analyze and process existing data sources to obtain useful information and knowledge. However, the data volume, which these sources reach, is often a limitation for analysis of manual way. Therefore, specialized technologies have been developed to process and obtain information of interest with the purpose of supporting the decision-making process.

Given these conditions, there is interest in analyzing the results of the evaluation offered by PLANEA in Higher-Middle Education 2017, since there is a notable difference between the levels of academic achievement achieved by students from one federative entity (state) to another in Mexico [7]. The purpose of this study is to identify elements and significant characteristics of academic achievement, in the domains of Language and Communication (reading comprehension) and Mathematics, of students of public and private institutions of the country through methods of data analysis. The data patterns obtained could be useful as an information tool for parents, students, teachers, principals, educational authorities and society in general.

\section{Background}

In Mexico, Higher-Middle Education acquired greater responsibilities in both coverage and education quality that imparts to its students, since at present it is 
evident the relevance of education imparted in that level and the impact that it will have on the development of the country [8]. In this context, it is important to mention that Mexico, in Higher-Middle Education, seeks the compulsory nature and strengthening of the selection procedures for entry and graduation of said school level [9].

Consequently, it is important to describe the role of PLANEA in Higher-Middle Education, which is designed to offer specific information on the academic achievement of schools and their students. This properly used plan is a powerful recognition tool to improve the quality of education.

The evaluation carried out by PLANEA in Higher-Middle Education is aimed at students throughout the Mexican Republic who are in the last school year (semester, year, or any other variant defined by the educational institution), enrolled in a campus or institution educational, whether autonomous, state, federal or private. Areas of competence that PLANEA currently evaluates at this level of education are Language and Communication and Mathematics, which have the following characteristics $[4,6]$ :

- Language and Communication. In this domain, the students' abilities to reflect, interpret, analyze and use written texts are explored through the identification of their structure, functions, and elements. All this with the purpose of employing communicative competitiveness and allowing it to actively intervene in society.

- Mathematics. In this domain, the students' abilities to identify, apply, synthesize, interpret and evaluate their environment mathematically are explored, making use of their creativity and logical and critical thinking, which allows them to solve different quantitative problems.

In the case of Language and Communication, the indicators associated with reading comprehension competences are subject to measurement, therefore, the evaluation topics focused on the processes associated with reading, such as extraction of information, interpretation, and reflection on language nature, and its use as a tool of logical thinking. Among the indicators evaluated in this domain are $[4,7]$ :

- Identification, ordering, and interpretation of ideas, data and explicit and implicit concepts in a text, considering the context in which it was generated and in which it is received.

- Evaluation of text by comparing the content, previous and new knowledge.

- Identification of the normative use of the language, considering the intention and the communicative situation.

- Analysis of a precise, coherent and creative argument.

- Relation of ideas and concepts coherent and creative compositions, with introductions, development and clear conclusions.

- Sequence evaluation, or logical relationship in the communication process.

- Identification and interpretation of the general idea and possible development of a written message, drawing on previous knowledge and the cultural context. 
For Mathematics, the aim is to encourage the development of creativity and logical-critical thinking in students, considering that a student can better argue and structure their ideas and reasoning. Therefore, given the standardization that is sought in the evaluation process, as well as the use of multiple choice reagents, the exercises to solve do not require the use of calculators or specialized formulas. Among the indicators evaluated in this domain are $[4,7]$ :

- Interpretation of mathematical models through the application of arithmetic, algebraic, geometric and variational procedures for the understanding and analysis of real and hypothetical situations.

- Solving mathematical problems, applying different approaches.

- Interpretation of data obtained through mathematical procedures and contrast with established models or real situations.

- Analysis of relationships between two or more variables of a social or natural process to determine their behavior.

- Quantification and mathematical representation of magnitudes of space and the physical properties of the objects that surround it.

- Reading of tables, graphs, maps, diagrams, and texts with mathematical and scientific symbols.

The first PLANEA evaluation in Higher-Middle Education was held in March 2015, the second in April 2016, while the third was in April 2017. These evaluations were made to students in the upper middle level of the last school year of public and private schools of the country. Table 1 shows the number of schools and students that participated in the three editions of the PLANEA evaluation in Higher-Middle Education.

Specifically, the aspects evaluated are aimed at measuring the academic achievement, highlighting the knowledge that a student of the upper-middle level must have to continue their academic life. Therefore, PLANEA constitutes a general diagnosis that can support self-directed intentions, enrollment in extracurricular activities, planning campaigns within schools, and other actions.

In order to guarantee that the evaluation of PLANEA will be carried out under homogeneous conditions throughout the country and to contribute to the reliability of the results obtained, some measures were implemented to strengthen the procedure for applying the test, such as [10]: (a) training on regulatory and operational aspects; (b) integration of personal files in order to verify that they meet the required profile; (c) use of optical reading to obtain fast information about the application and frequent incidents, and (d) use of a digital monitoring system to monitor the main activities scheduled before, during and after; to mention a few.

\begin{tabular}{ccc}
\hline Year & Schools & Students \\
\hline 2015 & 14,548 & $1,037,775$ \\
\hline 2016 & 14,784 & 579,923 \\
\hline 2017 & 16,380 & 585,552 \\
\hline
\end{tabular}

Table 1.

Schools and students participating in the PLANEA evaluation in higher-middle education. 


\section{Materials and methods}

As a method of work to analyze the academic achievement of students of highermiddle education in Mexico, a qualitative and quantitative approach was used. For this, data from the National Plan for the Evaluation of Learning was used, operated by the National Institute for the Evaluation of Education and the Secretariat of Public Education of Mexico. For the analysis of results, variables relevant to the current context of educational evaluation in Mexico were used.

\subsection{Data source}

As a data source, records were used from the National Plan for the Evaluation of Learning database (PLANEA), specifically data from schools of Higher-Middle Education, public, federal and state, and private schools recognized by the Secretariat of Public Education of Mexico.

Access to the version of the data source was made through the institutional PLANEA page (http://planea.sep.gob.mx/ms/base_de_datos_2017). PLANEA's main aim is to know to what extent students manage to master a set of essential learning at different times of their compulsory education $[7,11,12]$, in this case at the end of Higher-Middle Education, in two areas of competence: (a) Language and Communication, and (b) Mathematics.

In 2017, PLANEA used, as an evaluation instrument, an exam consisting of 100 multiple-choice items, divided into two educational competencies: (a) 50 for Language and Communication and (b) 50 for Mathematics. The test application includes 50-minute sessions distributed over 2 days. It is a diagnostic test; it is not a selection test for admission to Higher Education institutions. Table 2 shows the points evaluated in Language and Communication and Mathematics.

For 2017, 16,380 institutions, federal and state, public, autonomous and private with official validity and recognized by the Secretariat of Public Education were evaluated [4]. PLANEA in Higher-Middle Education qualifies educational competences acquired in four levels of academic achievement [7, 10]: (a) I, insufficient; (b) II, elementary; (c) III, satisfactory; and (d) IV, outstanding. These levels

\begin{tabular}{lc}
\hline Themes & Items number \\
\hline Language and communication & \\
\hline Management and construction of information & 18 \\
\hline Argumentative text & 11 \\
\hline Expositive text & 11 \\
\hline Literary text & 10 \\
\hline Total & 50 \\
\hline Mathematics & 18 \\
\hline Number sense and algebraic thinking & 17 \\
\hline Changes and relationships & 5 \\
\hline Form, space and measure & 10 \\
\hline Information management & 50 \\
\hline Total & 5 \\
\hline
\end{tabular}

Table 2.

Elements evaluated in language and communication, and mathematics. 
describe the performance that a student in the last school year can obtain as a qualification in the PLANEA evaluation. These levels represent the tasks and cognitive processes that students should achieve when they graduate from high-middle in the areas of Language and Communication, and Mathematics. These proficiency levels not only serve to identify the academic achievement that students have but also to have an overview of the performance of schools in general.

\subsection{Academic achievement levels}

Based on the foregoing, PLANEA clusters academic achievement into four levels that provide information about the key learning that must be acquired by students, and to what extent they have appropriated them [13]. These levels go from I to IV in progressive order, that is, the lowest level is I (insufficient) and the highest is IV (outstanding). These levels of academic achievement constitute an important reference for the detailed analysis of the results [4]. The levels are cumulative, that is, those students who have acquired the learning of a certain level have those of the previous level, for example, those who are located in level II (elementary), they already have the level I learning (insufficient); those who are in level III (satisfactory), have those of II and those of I, and so on.

PLANEA in the Higher-Middle Education is designed to offer parents, students, teachers, principals, educational authorities and society in general, specific information about the academic achievement of the schools and, properly used, constitutes an instrument that could contribute to improving the quality of education. The four levels of academic achievement have the following characteristics [7]:

- Level I (Insufficient). The students who are located at this level have insufficient knowledge of the key learning included in the curricular references. This reflects greater difficulties to continue with their academic career.

- Level II (Elementary). The students who are located in this level have an elementary knowledge of the key learning included in the curricular referents.

- Level III (Satisfactory). The students who are located in this level have a satisfactory knowledge of the key learning included in the curricular referents.

- Level IV (Outstanding). The students that are located in this level have an outstanding knowledge of the key learning included in the curricular referents.

\subsection{General procedure of PLANEA}

For the execution of PLANEA, National Institute for the Evaluation of Education and Secretariat of Public Education have the support of the State Evaluation Areas of each federal entity $[10,12]$. So, in the first instance, principals of the educational campuses are notified with approximately 8 days in advance to facilitate the ordering of the application groups and to implement strategies to ensure the participation of students.

The evaluation seeks to minimize any modification to normal school activities. Since the test only applies to students in the last grade, classes and school activities are not suspended for the rest of the students.

A Coordinator-Applicator participates per school who, together with the external applicator (if applicable), meets with the principal to explain in detail the logistics of application. The Coordinator-Applicator transfers the evaluation 
materials to the school in sealed boxes to guarantee the confidentiality of the test, and they are only open in the presence of the principal, parents, and observers.

The day of the evaluation is attended by external observers (parents and community leaders, businessmen, among others) who supervise that the test is carried out in accordance with established regulations. These people do not intervene in the evaluation process.

The principals of all the participating schools answer, through Internet, a context questionnaire that has the purpose of obtaining information about the characteristics of the school. For their part, the students evaluated also answer a context questionnaire to gather information about school climate and sociocultural aspects.

\subsection{Clustering methods}

Clustering is the descriptive analysis par excellence of data mining. It consists of generating 'natural' clusters from the data [14]. A cluster consists of one or more data vectors, in turn, these vectors comprise several attributes (variables). The aim of this method is to divide a heterogeneous data set into homogeneous sub-clusters based on the similarities of their records [15]. There are two main types of clustering [16]: (a) hierarchical, which is characterized by the recursive development of a structure in the form of a tree, and (b) partition, which organizes records within $\mathrm{k}$ clusters. Partition-methods have advantages when a large amount of data is involved, since the construction of a tree is complex.

\section{Results and discussion}

Derived from the PLANEA data analysis, a data view was obtained. The main consideration was to determine how many and which are the appropriate variables for the study. Table 3 shows the structure of the data view consisting of 17 significant variables and 16,380 records.

\subsection{Results at national level}

As a result of the analysis, it was observed in Language and Communication (Figure 1), at the national level, that one-third of the students (33.9\%) who are about to finish upper-middle education were located in Level I (insufficient). While on average 1 out of every 3 students were located in both Level II-elemental(28.1\%), and in Level III-satisfactory-(28.7\%), respectively; and only 9 out of 100 students (9.2\%) were located in Level IV (outstanding).

Students located in Level I were not able to identify the author's position in opinion articles, essays or critical reviews; nor were they able to explain the information of simple text with words other than those of reading. In the case of students located in Level II, they were able to identify main ideas that support the proposal of a brief opinion article, discriminated and related timely and reliable information, and organized it based on a purpose. Students in Level III recognized in an opinion article the purpose, the argumentative connectors and the parts that constitute it; in addition, they identified the differences between objective information, opinion, and evaluation of the author; they also identified the different ways in which written language is used according to the communicative purpose and used strategies to understand what they read. While Level IV students selected and organized pertinent information from an argumentative text, they identified the author's position, interpreted information from argumentative texts, such as critical reviews and opinion articles, and inferred the paraphrase of expository text, such as a divulgation article. 


\begin{tabular}{|c|c|c|}
\hline Item & Variable & Description \\
\hline 1 & School & School name \\
\hline 2 & Innings & Class schedule \\
\hline 3 & Entity & Federative entity name \\
\hline 4 & Municipality & Municipality name \\
\hline 5 & Subsystem & Education subsystem \\
\hline 6 & Sustenance & Sustenance type \\
\hline 7 & Students_evaluated & Total of students evaluated \\
\hline 8 & Students_evaluated_L\&C & Students evaluated in Language and Communication \\
\hline 9 & Students_evaluated_Math & Students evaluated in Mathematics \\
\hline 10 & Achievement_L\&C_Level_I & $\begin{array}{l}\text { Students located in Level I (Language and } \\
\text { Communication) }\end{array}$ \\
\hline 11 & Achievement_L\&C_Level_II & $\begin{array}{l}\text { Students located in Level II (Language and } \\
\text { Communication) }\end{array}$ \\
\hline 12 & Achievement_L\&C_Level_III & $\begin{array}{l}\text { Students located in Level III (Language and } \\
\text { Communication) }\end{array}$ \\
\hline 13 & Achievement_L\&C_Level_IV & $\begin{array}{l}\text { Students located in Level IV (Language and } \\
\text { Communication) }\end{array}$ \\
\hline 14 & Achievement_Math_Level_I & Students located in Level I (Mathematics) \\
\hline 15 & Achievement_Math_Level_II & Students located in Level II (Mathematics) \\
\hline 16 & Achievement_Math_Level_III & Students located in Level III (Mathematics) \\
\hline 17 & Achievement_Math_Level_IV & Students located in Level IV (Mathematics) \\
\hline
\end{tabular}

Table 3.

Variables that make up the data view for the analysis of academic achievement.

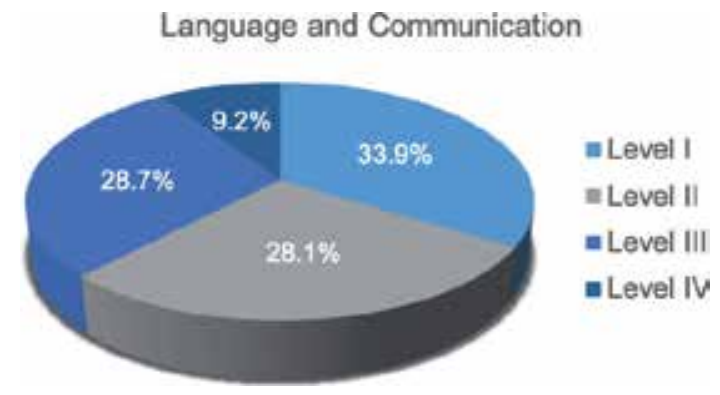

Figure 1.

Academic achievement in language and communication at the national level.

In Mathematics (Figure 2), 6 out of 10 students were placed in Level I-insufficient-(66.2\%); approximately 2 out of 10 were located in Level II-elemental(23.3\%); in Level III only 8 out of every 100 students (8\%) achieved a satisfactory domain; while in Level IV, 3 students out of every 100 (2.5\%) achieved outstanding proficiency.

Students located in Level I had difficulties to perform operations with fractions and operations that combine unknowns or variables (represented by letters), as well as to establish and analyze relationships between two variables. On the other hand, students located in Level II expressed, in mathematical language, situations where a value is unknown or the relations of proportionality between two variables, 


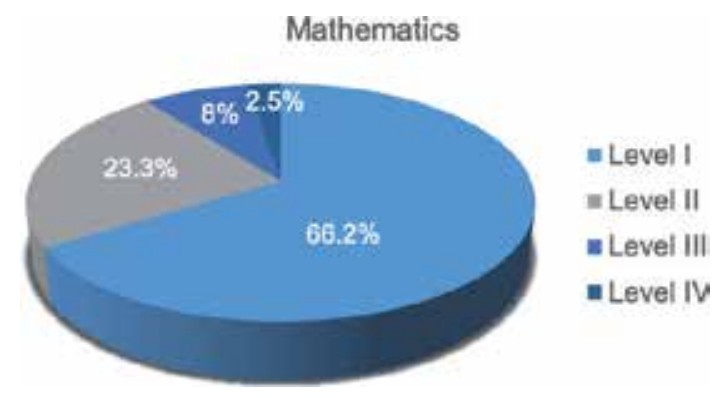

Figure 2.

Academic achievement in mathematics at the national level.

and solved problems that implied proportions between quantities, for example, the calculation of percentages. In the case of students located in Level III, they used mathematical language to solve problems that required the calculation of unknown values, and to analyze situations of proportionality. While those located in Level IV dominated the rules to transform and operate with mathematical language (for example, the laws of signs); they expressed in mathematical language the relationships that exist between two variables of a situation or phenomenon; and they determined some of their characteristics, for example, they deduced the equation of the straight line from its graph.

\subsection{Results at state level}

In Language and Communication, the entities that had a lower average score, with respect to the national average and that is significant, were Chiapas, Tabasco, Guerrero, and Michoacán (Figure 3). The entities that had a higher average score with respect to the national average were Mexico City, Aguascalientes, Jalisco, Baja California, Querétaro, Yucatán, Colima, and Nuevo León. Chiapas was the entity with the highest percentage of students in Level I (66.1\%), while Mexico City was the entity with the lowest percentage of students in this Level I (17.8\%). Likewise, Mexico City had the highest percentage of students in Level IV (15.9\%). There is a significant difference between the highest score (Mexico City) and the lowest score (Chiapas). The states with the highest percentages of students in Level IV, aside

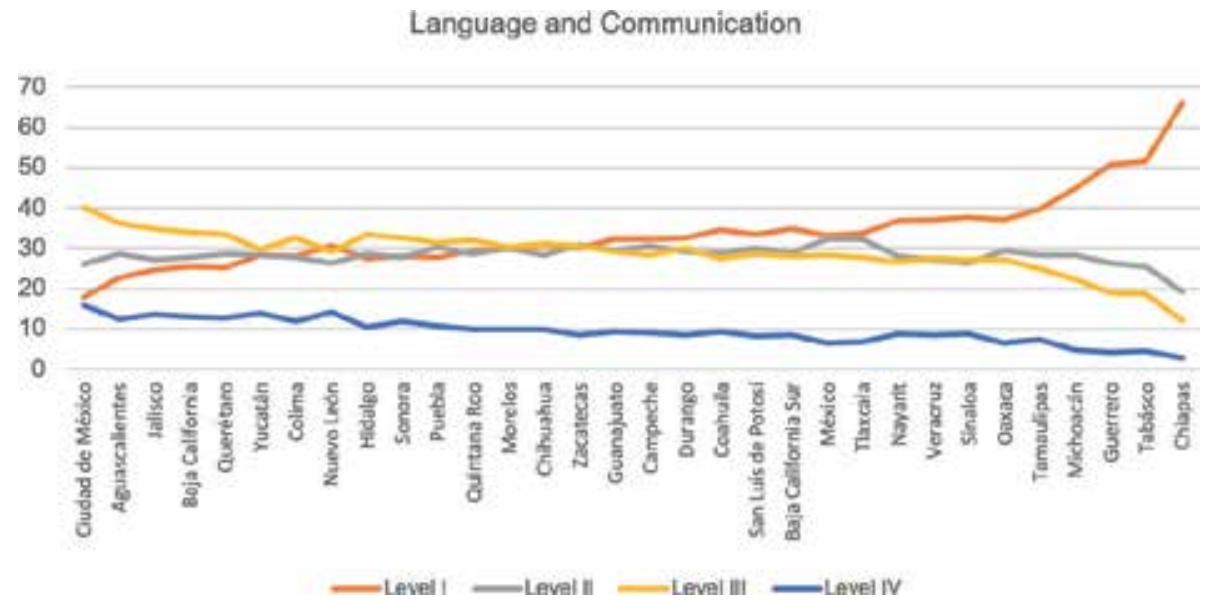

Figure 3.

Academic achievement in language and communication at state level. 
from Mexico City, were Nuevo León, Yucatán, Jalisco, Baja California, Querétaro, Aguascalientes, Colima, Hidalgo, Sonora and Puebla.

In Mathematics (Figure 4), the entities that had a lower average score with respect to the national average were Chiapas, Tabasco, Guerrero, Michoacán, and Tamaulipas. The entities that had a higher average score and with a significant difference with respect to the national average were Aguascalientes, Jalisco, Querétaro, Baja California, Colima, and Nuevo León. There is a significant difference between the highest score (Aguascalientes) and the lowest score (Chiapas). The entity with the highest percentage of students in Level I was Chiapas (85.6\%), while Aguascalientes was the state with the lowest percentage of students in Level I (53.3\%). When comparing the results in Mathematics of all the states, Nuevo León had the highest percentage of students in Level IV (5.1\%), followed by Colima (4.3\%) and Coahuila (4\%), the rest was below said percentage values.

The difference in the scores that are observed, from one entity to another, could be linked to the heterogeneity of the service that the educational institutions provide. Similarly, there may also be differences between students who attend the same type of school. On the one hand, there are public institutions, which serve an important cluster of Higher-Middle Education; and on the other hand, there are private institutions, which serve the population that was not accepted in public institutions or decided this type of education, with periodic payments and others with high costs that, in turn, usually provide better conditions in their offer educational. On the other hand, the differences in academic achievement may be conditioned by the students' socioeconomic level, because it is a source of accumulation of educational opportunities.

\subsection{Results by control type}

In Language and Communication (Figure 5a), the academic achievement levels of students of autonomous schools reflected a better performance than students from federal, private and state institutions, given that only $20.4 \%$ of the students were placed in Level I, in contrast to 28.2, 27.5 and 41.9\%, respectively. The highest percentage of students located in the highest (outstanding) achievement level corresponds to autonomous institutions $(17.4 \%)$, then private schools $(16.1 \%)$ were located, followed by federal schools (9.2\%) and finally state schools (4.8\%).

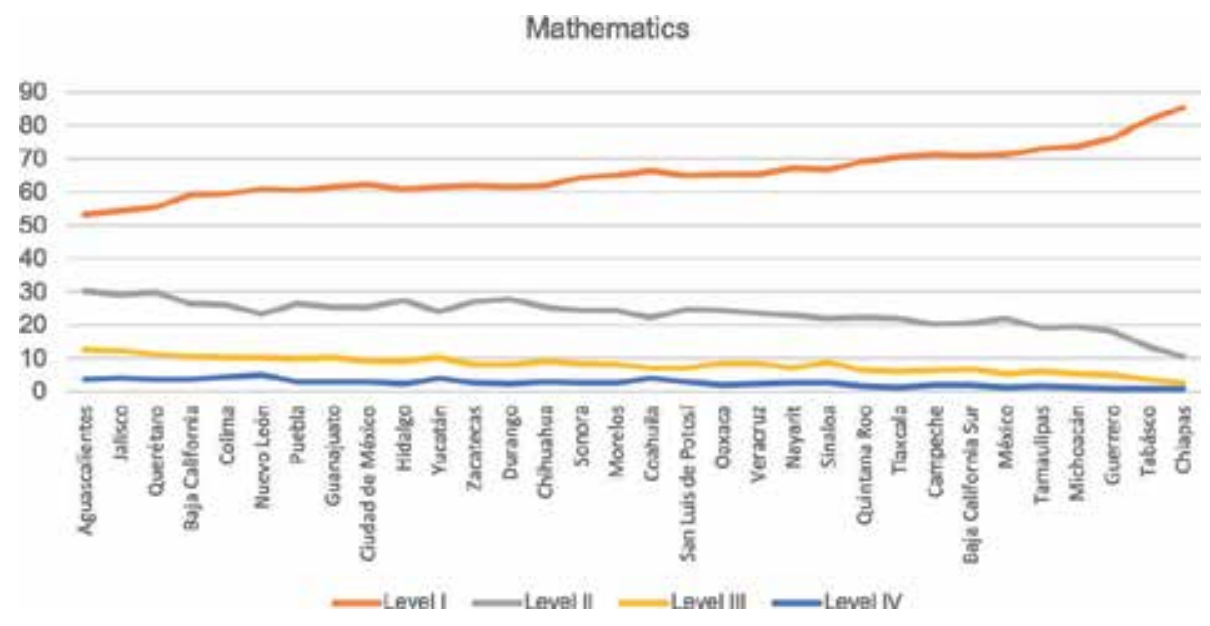

Figure 4.

Academic achievement in mathematics at state level. 


\section{Language and Communication}

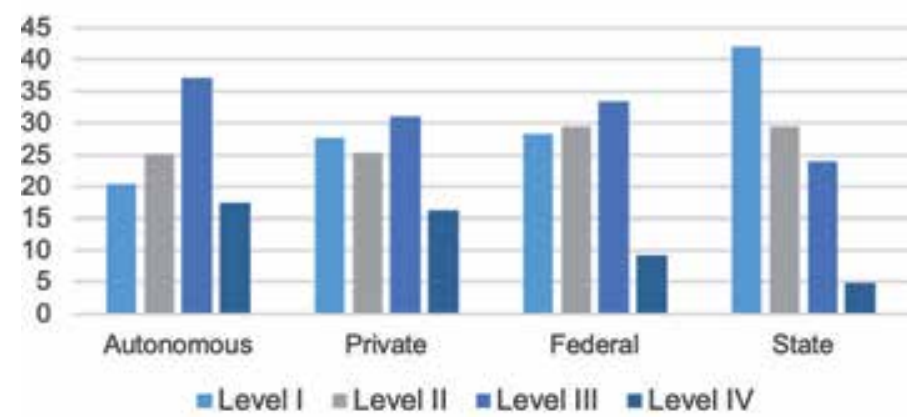

(a)

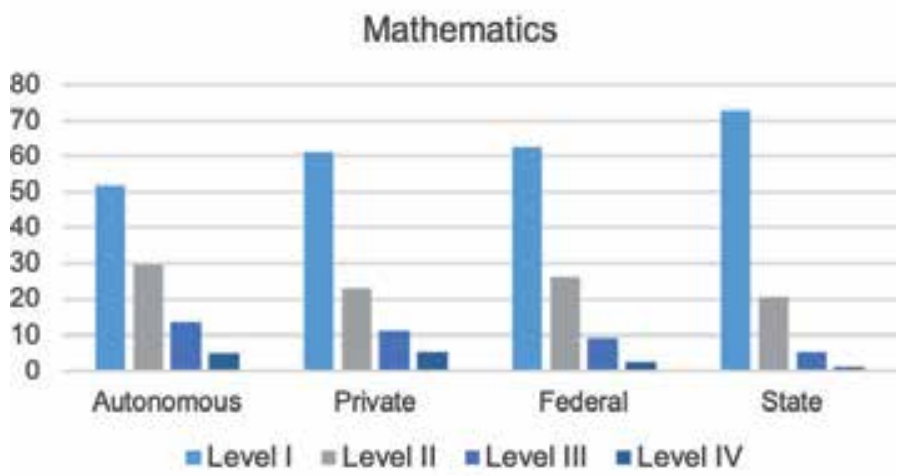

(b)

Figure 5.

Academic achievements by type of administrative control: autonomous, private, federal and state schools. (a) corresponds to academic achievement in Language and Communication, and (b) corresponds to academic achievement in Mathematics.

In Mathematics (Figure 5b), students of state schools had the lowest performance, with $73 \%$ in Level I -Insufficient- this compared to the other types of administrative control. In the other extreme, in the highest level (IV, outstanding), in general, no type of educational institution exceeds $6 \%$, that is, only private $(5.1 \%)$ and autonomous (4.8\%) schools were the best performers. This situation contrasts the low educational levels in Mathematics of students in Higher-Middle Education.

\section{Conclusions}

Education is one of the key pillars for the social and economic development of a country. Therefore, in order to obtain satisfactory results, a quality education is needed; which is achieved through educational systems that have a decisive role in the improvement of educational quality.

Academic achievement analysis offers timely information that could be useful to know the successes and challenges that are found in the learning of the contents of the areas evaluated, thus contributing to the development for the improvement of the educational system.

The results of PLANEA 2017 allow an overview of the levels of academic achievement, in Language and Communication and Mathematics. Results indicate that there is inequity among the students who attend the different educational centers. If a periodic follow-up is carried out, it will be possible to know if the distances are shortened. 
Results confirm the low educational levels at the national level of the students of Higher-Middle Education of the National Educational System. In Language and Communication, $34 \%$ of students were located in Level I (the lowest), and $66 \%$ in Level I of Mathematics. These students have not consolidated the keys learning that were evaluated in the PLANEA 2017 test, such as making implicit content inferences in different types of text or making inferences from a mathematical model. At the other extreme, in Language and Communication, only $9 \%$ of students are in Level IV (the highest), and in Mathematics only 3\%.

Results of academic achievement are a reflection of various social, cultural and economic factors, from students' school activities such as habits, attitudes, and values, to the conditions of educational institutions and the socioeconomic context in which they live. In addition, due to the diversity of educational institutions of the National Education System. Therefore, the improvement of educational achievement requires differentiated attention in each entity, type of service and type of administrative control.

Undoubtedly, the academic achievement of students of Higher-Middle Education is linked to the results of previous educational levels. To address this situation, it is necessary to reduce knowledge gaps, opportunities and general conditions of teaching and learning, from the beginning of compulsory education.

In this sense, the results show that there is a huge challenge ahead for HigherMiddle Education, this challenge implies that coordinated efforts of many actors from previous educational levels are also required so that all students can fully exercise their right to receive an education quality.

In the case of Language and Communication, one of the initiatives may be the promotion of reading different text carriers and the critical analysis of them. The support of other subjects to carry out similar activities, including choosing articles, stories or books that students propose, helps to exercise cognitive processes that will be refined to develop a reading competence.

For Mathematics, in addition to emphasizing the role of the practice of the exercises and activities, it is advisable to multiply the occasions in which the student faces to solve contextualized problems and, progressively, of greater difficulty. The complexity of the exercises depends on the number of variables that need to be considered and the type of language needed to represent the situations. These aspects are enhanced when the contents are taught through problems in everyday scenarios, contrary to what happens with direct situations or exercises of mere resolution of operations.

\section{Conflict of interest}

The authors declare that they have no conflicts of interest with respect to the investigation, authorship, and publication of this book chapter. 
Analysis of Academic Achievement in Higher-Middle Education in Mexico through Data... DOI: http://dx.doi.org/10.5772/intechopen.84744

\section{Author details}

Guillermo Molero-Castillo ${ }^{1 *}$, Everardo Bárcenas ${ }^{1}$, Alejandro Velázquez-Mena ${ }^{1}$ and Yaimara Céspedes-González ${ }^{2}$

1 Engineering Faculty, National Autonomous University of Mexico, Mexico

2 University of Veracruz, Mexico

*Address all correspondence to: gmoleroca@fi-b.unam.mx

\section{IntechOpen}

(C) 2019 The Author(s). Licensee IntechOpen. This chapter is distributed under the terms of the Creative Commons Attribution License (http://creativecommons.org/licenses/ by/3.0), which permits unrestricted use, distribution, and reproduction in any medium, provided the original work is properly cited. (cc) BY 


\section{References}

[1] Molero-Castillo G, MaldonadoHernández G, Mezura-Godoy C, Benítez-Guerrero E. Interactive system for the analysis of academic achievement at the upper-middle education in Mexico. Computación y Sistemas. 2018;22(1):223-233. DOI: 10.13053/CyS-22-1-2773

[2] Arnaut A, Giorguli S, editors. Los grandes problemas de México. Educación. 1st ed. El Colegio de México: Mexico City; 2010.684 p. ISBN: 978-607-462-167-9

[3] De Ibarrola M. Los grandes problemas del sistema educativo mexicano. Perfiles educativos. 2012;34:16-28. ISSN: 0185-2698

[4] SEP. Plan Nacional para la Evaluación de los Aprendizajes en la Educación Media Superior [Internet]. 2018. Available from: http://planea.sep.gob. $\mathrm{mx} / \mathrm{ms}$ [Accessed: 22 November 2018]

[5] INEE. PLANEA 2017 Educación Media Superior Marco de Referencia del cuestionario del alumno [report]. Mexico City: National Institute for the Evaluation of Education; 2017

[6] SEP. Manual para usuarios Plan Nacional para las Evaluaciones de los Aprendizajes en el nivel medio superior [report]. Mexico City: Centro Nacional de Evaluación para la Educación Superior, A. C; 2016

[7] INEE. El ABC de PLANEA [Internet]. 2017. Available from: www.inee.edu.mx/index.php/planeafasciculos-2 [Accessed: 24 November 2018]

[8] Martínez M. editor. La educación media superior en México. Balance y perspectivas. Fondo de Cultura Económica: Mexico City; 2012. 291 p. ISBN: 978-607-16-0851-2
[9] Villa L. Modernización de la educación superior, alternancia política y desigualdad en México. Revista de la Educación Superior. 2013;42(168):81103. ISSN: 0185-2760

[10] SEP. Procedimiento general PLANEA, Educación Media Superior. 2017. [Internet]. Available from: http:// planea.sep.gob.mx/ms/aplicacion/ procedimiento_genera [Accessed: 26 November 2018]

[11] INEE. Plan Nacional para la Evaluación de los Aprendizajes (PLANEA) [report]. National Institute for the Evaluation of Education: Mexico City; 2015

[12] SEP. Lineamientos Generales para la Aplicación PLANEA [report]. Mexico City: Secretary of Public Education; 2017

[13] INEE. Planea: Una nueva generación de pruebas [report]. National Institute for the Evaluation of Education: Mexico City; 2016

[14] Molero-Castillo G, Meda-Campaña M. Climatic regionalization using data mining techniques: A case of study. In: Proceedings of the IEEE Xplore 6th Colombian Computing Congress (CCC); 4-6 May 2011. Colombia: IEEE; 2011. pp. 7-12

[15] Sumathi S, Sivanandam S, editors. Introduction to Data Mining and its Applications. Berlin: Springer-Verlag; 2006. 828 p. ISBN: $1860-9503$

[16] Larose D. Discovering Knowledge in Data: An Introduction to Data Mining. 1st ed. New Jersey: Wiley \& Sons; 2005. 222 p. ISBN: 0-471-66657-2 

Decision of Ivorian Households

\author{
N'da Koffi Christan
}

\begin{abstract}
Faced with unlimited needs, the scarcity of resources forces economic agents to make choices. The analysis using discrete choice models aims to identify the bases of these decisions. The aim here is to highlight the explanatory factors of the demand for education by Ivorian households for their children. To do this, the simple logit model is applied to explain the decision of schooling children. Then the multinomial logit model is used to explain the continuation of education. Household living standard survey data of 1998 and 2008 are used. It shows that age, household composition, and the provision of primary and secondary education services have a positive influence on the education of children. Income influences only high school education. The effects of sociodemographic factors vary by region. Security and accessibility of administrative services encourage the education of children.
\end{abstract}

Keywords: logit, multinomial logit, education, human capital, decision

\title{
1. Introduction
}

Through education, the individual acquires a set of general or specific knowledge or know-how that is determinant in the production process. The knowledge accumulation is an important source of economic growth [1,2]. It slows the rate of change to the steady state by mitigating the effects of diminishing returns on physical capital accumulation. This leads to a positive long-term growth rate since the accumulation of knowledge is proportional to the stock of existing knowledge. In addition, the stock of knowledge affects a country's ability to innovate (see [3]). Education determines the employee's ability to perform tasks and allows them to integrate technology and/or the environment of technological innovation.

Côte d'Ivoire has made training one of its priorities as soon as it attains independence with an education-training sector budget of about $40 \%$ of the general state budget [4]. The aim was to generalize primary education and ensure the growth and development of secondary and higher education. But, the successive crises of the 1980s will slow down this momentum. At the end of the structural adjustment program (SAP), the state undertook to reinvigorate education policy by adopting a new legal framework that makes education the means by which all individuals integrate socially, culturally, and professionally and exercise their citizenship (Art. 1, Law No. 95-696 of 7/09/1995). 
The private sector participates in the provision of education in all three levels of formal education. For the years 2010-2011 and 2011-2012, it trained, respectively, 14.17 and $12.26 \%$ of primary students, 32.06 and $43.27 \%$ of lower secondary general education, 32.23 and $44.74 \%$ of upper secondary general education, and $60.41 \%$ of learners in technical and vocational education. However, this public-private collaboration did not achieve the goal of Education for All in 2015 [5].

Therefore, it seems of interest to seek to understand the fundamentals of the education decision of the Ivorian households. We are looking for ways to ensure that all children are able to attend school and complete the educational process by studying the basis of the demand for education in order to highlight the determinants of household choice, considering three main categories of actors: the household, the child, and the public authorities.

For individuals, investing in education provides economic and social returns. It increases both employment rates and labor income. But, education requires the learner's full involvement in the training process, hence the importance of time in the cost of training [6]. However, the possibilities of accumulation of knowledge depend on the physical and intellectual capacities of the individual, supposed to decrease with the age of the individual.

It has been proven that the sources of motivation for studies must be sought in the financial benefits of education and competition in the labor market [7] so that the duration of studies is positively correlated with the level of remuneration of work. This makes it possible to cover the costs of the years of study. Also, the more or less strong mobility of the productive factors which characterizes the generalized liberalization of the markets makes that the labor market becomes more and more competitive. The labor market is also a market where very often the sectors or branches of activity (segments) require specific knowledge. As a result, mobility between industries requires additional investment in education. Moreover, the personalization of the training constitutes a natural protection against the risks of appropriation by others. The effectiveness of this protection increases the incentive to invest in oneself [6]. But this customization limits external funding opportunities for investment in education.

Investment in education also serves social purposes [8]. Some works on the determinants of differences in levels of life in various long-term economies have reignited the debate about endogenous growth theory, empirical growth analysis, and convergence (i.e., [2, 9-11]). Education plays a key role in countries' ability to innovate [4]. And investment in education follows logic of maximization of utility [12].

Moreover, integrations of the intergenerational transfers required in the explanation of the education decision show that the lack of a market to finance educational investment makes young people captive to parental funding [13]. This in turn forces them to pay back to their parents the highest possible share of their activity income.

From a macroeconomic point of view, public intervention is important to maintain their labor force as unemployed, given the costs associated with this maintenance [14]. But such a selective and discriminatory policy may discourage the individual interview of their skills by all the unemployed. One advocated a generalized credit system that allows young people to study and reimburse fees when they are active (i.e., [15]). Otherwise, the level of education will be zero. Therefore, the public supply of education aims to correct this failure of the financing system and encourage the expression of a latent demand for education [16].

In sum, the demand for education is motivated by factors related to individual and collective social well-being. It is in this sense that the state sometimes substitutes itself to the market to generating the expression of a latent demand thanks 
to the public policy of education. The rest of this paper is structured as follows. Section 2 gives an overview of discrete choice models, and then the method of analysis and the data that will be used for the empirical analysis of the determinants of education are presented in Section 3. Section 4 presents the results and discusses them. Section 5 summarizes the main findings of the study.

\section{The discrete choice models}

In a decision-making process, it is a question of finding the best solution among the possible alternatives to satisfy the objectives. The decision can be continuous choice or discrete choice. In the first case, it amounts to choosing a combination of the quantity of possible alternatives where the quantities for each alternative can vary continuously. With the second option, it is a question of choosing only one alternative among several alternatives. We present in this section first the theoretical foundations of discrete choice models and then the mathematical formulas of the multinomial logit model.

\subsection{Theoretical basis of discrete choice models}

Suppose the consumer can compare all possible alternatives. There is a utility function $U$ that expresses consumer preferences. Let $C_{n}$ be the set of alternatives available to the $n$ decision-makers during the decision process, where $U_{i}$ is the utility of the decision-maker associated with the alternative $i$; the utility function can be defined in terms of attributes as follows:

$$
U_{i}=U\left(Z_{i}\right)
$$

where $Z_{i}$ is the vector of the attributes for the alternative $i$. Thus, for the decision-maker $\mathrm{n}$, the alternative $\mathrm{i}$ is chosen if and only if

$$
U_{i}>U_{j} \quad j \neq i, \quad i, j \in C_{n}
$$

In fact, when repeating the same choice test, or with the same set of choices, the same attributes, and the same socioeconomic characteristics, different individuals will choose different alternatives. The theory of probabilistic choice explains this inconsistency of the preferences of individuals. It is assumed that human behavior is intrinsically probabilistic or that more specific information about the individual decision-making process is lacking. The probabilistic mechanism can capture the effects of unobservable variations among decision-makers and the unobservable attributes of alternatives. It also considers the stochastic behavior and the error caused by the method of data collection.

Thus, the probabilistic characteristics of the choice decision make it possible to highlight the alternative that a decision-maker will choose in the decision-making process by calculating the probability that a decision-maker will choose the alternative. The hypothesis of the agent's rationality always assumes that individuals select alternatives with the highest utility. The probability that a decision-maker selects the alternative $i$ will be that the utility of this alternative $i$ is greater than that of the other alternatives:

$$
P_{i}=P_{i}\left(U_{i}>U_{j}, \forall j \neq i\right)
$$


Since the utilities are not known for certain, they must be treated as random variables by decomposing the random utility function of a two-part alternative:

$$
U_{i}=V_{i}+\varepsilon_{i}
$$

Since each agent has a set of choices designated by $C_{n}$, with $j<J$ as the number of choices (alternatives), the probability that the alternative $i$ in $C_{n}$ is chosen can be rewritten as

$$
\begin{aligned}
P(i) & =P\left(V_{i}+\varepsilon_{i} \geq V_{j}+\varepsilon_{j}, \forall j \in C_{n}, j \neq i\right) \\
& =P\left(\varepsilon_{j} \leq V_{i}-V_{j}+\varepsilon_{i}, \forall j \in C_{n}, j \neq i\right)
\end{aligned}
$$

where $\mathrm{V}_{\mathrm{i}}$ denotes the systematic component of utility and $\varepsilon_{i}$ refers to the random component of utility.

The determination of the model specification depends on the choice of the form of the utility function. This specification concerns the systematic component which is supposed to be a linear function on the parameters (acronym for "linear in parameters"). Let $\beta$, the vector of $\mathrm{k}$ unknown parameters, be the linear function on the parameters written as

$$
V_{i}=\beta_{1} X_{i 1}+\beta_{2} X_{i 2}+\ldots+\beta_{k} X_{i k}
$$

In the equation above, the parameters $\beta_{1}, \beta_{2}$, and $\beta_{k}$ are assumed to be the same for all. But in reality, the socioeconomic characteristics are not identical for all agents. The parameters must not be fixed and must instead be variable according to the different characteristics of the individuals. This problem can be solved by treating the parameter $\beta$ as a random variable that follows a probabilistic distribution.

Moreover, assuming that the chosen alternative $\mathrm{i}$ is the first alternative in $\mathrm{Cn}$ and $f\left(\varepsilon_{i}, \varepsilon_{2}, \ldots, \varepsilon_{j}\right)$ that the joint density function of the error terms is designated, the probability can be written in the form

$$
P(1)=\int_{\varepsilon_{1}=-\infty}^{\infty} d \varepsilon_{1 n} \int_{\varepsilon_{2=-\infty}}^{V_{1}-V_{2}+\varepsilon_{1}} d \varepsilon_{2} \ldots \int_{\varepsilon_{j=-\infty}}^{V_{1}-V_{j}+\varepsilon_{1}} f\left(\varepsilon_{1}, \ldots \varepsilon_{j}\right) d \varepsilon_{j}
$$

The density function of the error terms $\varepsilon_{j}$ depends on the correlation between these error terms. Correlations internal to the observations are the correlations between the residues relative to the different alternatives for the same individual. In this case, for every individual, we have $E \varepsilon_{j} \varepsilon_{j}^{\prime}=\sum_{n}$, and $\sum_{n}$ is no longer a diagonal matrix. By making assumptions about the joint probabilistic distribution of the error terms $\varepsilon_{j}$, any multinomial choice model can be deduced. In the following, only the multinomial logit model and the logit model with random parameters will be processed.

\subsection{Logit multinomial model}

If one assumes that they are independently and identically distributed (IID), hypothesis equivalent to the hypothesis independence of irrelevant alternatives (IIA), and that what follows them is a distribution of Gumbel, one obtains the multinomial logit model (MNL model): 


$$
P(i)=\frac{\exp \left(V_{j}\right)}{\sum_{j \in C_{n}} \exp \left(V_{j}\right)}
$$

If the utility function is linear on the parameters, the model is written as

$$
P(i)=\frac{\exp \left(\beta^{\prime} X_{i}\right)}{\sum_{j \in C_{n}} \exp \left(\beta^{\prime} X_{j}\right)}
$$

where $X_{i}$ is explanatory variables representing the socioeconomic and demographic characteristics of individuals, their environment, or contextual characteristics and $\beta$ is the parameters to estimate.

\subsection{Logit model with random parameters}

In the logit model, $\beta_{k}$ is constant (set for all individuals) and therefore cannot capture the effects of individual characteristics. To remove this constraint, we assume that $\beta_{k}$ is a random variable of specific or normal distribution. In this case, the probability of choice can be written in the following form:

$$
P(i)=\int_{-\infty}^{\infty} \int_{-\infty}^{\infty} \ldots \int_{-\infty}^{\infty} P^{\prime}(i) f\left(\beta_{k}, \ldots, \beta_{1}\right) d \beta_{k} \ldots d \beta_{1}
$$

where $f\left(\beta_{1}, \ldots, \beta_{k}\right)$ is the density function of the parameters of the individual utility function

$$
\text { with } P^{\prime}(i)=\frac{\exp \left(\beta^{\prime} X_{i}\right)}{\sum_{j \in C} \exp \left(\beta^{\prime} X_{j}\right)}
$$

For example, if $\mathrm{C}$ is the cost of education, $\mathrm{T}$ is the duration of education, and $\mathrm{X}$ is the other explanatory variables, the linear utility function is written as

$$
U_{i}=\beta_{c} C_{i}+\beta_{T} T_{i}+\alpha^{\prime} X_{i}+\varepsilon_{i}
$$

Assuming, moreover, that the coefficient of the duration of education $\beta_{T}$ takes a random value [17], of the normal type, the function of the probabilistic density $\beta_{T}$ is written as

$$
f\left(\beta_{T}\right)=\frac{1}{\sigma \beta_{T} \sqrt{2 \pi}} \exp \left[-\frac{1}{2}\left(\frac{\beta_{T}-\omega}{\sigma}\right)^{2}\right] \text { with } \beta_{T}>0
$$

In this case, the probability of choice can be written as follows:

$$
P(i)=\frac{1}{\sigma \sqrt{2 \pi}} \int_{0}^{\infty} \frac{\exp \left(\beta_{c} C_{i}+\beta_{T} T_{i}+\alpha X_{i}\right)}{\sum_{j=1}^{J} \exp \left(\beta_{c} C_{j}+\beta_{T} T_{j}+\alpha X_{j}\right)} * \frac{1}{\beta_{T}}\left[-\frac{1}{2}\left(\frac{\beta_{T}-\omega}{\sigma}\right)^{2}\right] d \beta_{T}
$$

Although this model is also based on the hypothesis IIA, the fact that the coefficients of the attributes can vary among the individuals improves the specification of 
the logit model. In the next section, the multinomial logit model will be applied to Ivorian data to explain the choice of Ivorian households in education.

\section{The household education decision}

This section presents the theoretical framework and method of analysis as well as the data sources for empirical applications.

\subsection{Theoretical framework of the analysis model}

The economic agent who invests in training expects a return higher than the cost of his investment in terms of labor compensation. Thus, a methodology is developed from gain functions (see [18-21]). Starting from Becker's models of education (see [22-24]), the demand for education can be modeled from the utility function of the household. Let us consider a model of choice of inter-temporal education where the representative household has only one child and lives two periods (i.e., [25]). The household derives its utility from the consumption of goods and services (C) and the cognitive skills of its child (A). In period 1, the child may be in school, work, or both. In the latter case, the child goes to school first and works after school [26]. The utility function of the household can then be written as

$$
U=C_{1}+\delta C_{2}+\sigma A
$$

where $\delta$ is the discount factor of future consumption and $\sigma$ represents parents' preferences for child-rearing. Children's education can increase parental consumption. It also directly affects the usefulness of parents. The acquisition of cognitive skills can be expressed using a production function as follows:

$$
A=\alpha f(Q) g(S)
$$

where $\alpha$ is the child's learning efficiency that encompasses a number of factors, such as the child's learning abilities and motivation and the parents' ability to support their child in school work, Q is the quality of the school, and $S$ is the grade. The parents' consumption in each period is expressed as follows:

$$
\begin{gathered}
C_{1}=Y_{1}-p S+(1-S) k Y_{c} \\
C_{2}=Y_{2}+k Y_{c}
\end{gathered}
$$

where $\mathrm{p}$ is the price of education and $Y_{1}$ and $Y_{2}$ are the income of parents at periods 1 and 2. $Y_{c}$ is the child's income when working and the share of that income paid to parents. 1-S is the time the child devotes to work. Income is completely exhausted at the end of each period. The household does not go into debt either. Children's income can be modeled on cognitive skills:

$$
Y_{c}=\pi A
$$

where $\pi$ is the productivity of cognitive skills in the labor market.

Substituting Eq. (16) in Eq. (19), Eq. (19) in Eqs. (17) and (18), and Eqs. (16)-(18) in Eq. (15), the utility function of parents is written as a function of years of schooling and the quality of the school:

$$
U=Y_{1}-p_{0} S+\delta Y_{2}+[(1-S+\delta) k \pi+\sigma] \alpha f(Q) g(S)
$$


If the quality of the school is considered exogenous, then the variable that determines the choice is the time of education (S). The optimal duration of education is obtained by maximizing the utility function of the household. But, parents have the opportunity to also choose the quality of the school they want for their child. Thus, the price of education will depend on the quality of the school:

$$
p=p_{0} Q
$$

where $p_{0}$ is the basic price of education. By replacing $p$ by $p_{0} Q$ in Eq. (6), we obtain the expression of the utility function to be maximized according to the quality variables $(\mathrm{Q})$ and the study time $(\mathrm{S})$ :

$$
U=Y_{1}-p_{0} Q S+\delta Y_{2}+[(1-S+\delta) k \pi+\sigma] \alpha f(Q) g(S)
$$

To simplify derivation calculations, one postulates that the quality function of the school and the duration of education have the following functional forms (see [27]): $f(Q)=Q^{\beta}$ and $g(S)=S^{\gamma}$ with $\beta>0 ; \gamma>0$. One can then write the functional form of the utility function of the parents as being equal to

$$
U=Y_{1}-p_{0} Q S+\delta Y_{2}+[(1-S+\delta) k \pi+\sigma] \alpha Q^{\beta} S^{\gamma}
$$

Maximizing the utility function of parents following S and Q determines the optimal values of the length of education and the quality of the school:

$$
S^{*}=\frac{(\gamma-\beta)\left(1+\delta+\frac{\sigma}{k \pi}\right)}{(1+\gamma-\beta)}
$$

$S^{*}$ is positive if and only if $(\gamma-\beta) \geq 0$. The sensitivity of cognitive skills to learning times must be greater than the sensitivity of cognitive skills to the quality of the school. Eq. (24) suggests that parents' preferences for education and future consumption have a positive influence on the length of their child's education. But when the share of his income that the child has to give back to his parents increases less he makes long studies. Also, a high productivity of cognitive skills in the labor market will encourage the child to opt for work earlier than education:

$$
Q^{*}=\left(\frac{\alpha \beta k \pi}{p_{0}}\right)^{\gamma-1}\left[\frac{\left(1+\delta+\frac{\sigma}{k \pi}\right)}{1+\gamma-\beta}\right]^{\gamma}
$$

From Eq. (25), we conclude that the child's learning abilities, preferences for future consumption, and parents' level of education are positively related to the quality of children's education. On the other hand, the basic price of education negatively influences the quality of education that parents are willing to choose for their child.

The level of knowledge acquisition is determined by integrating Eqs. (24) and (25) into the cognitive skill acquisition equation. The production of cognitive skills can be expressed in a linear form for the sake of simplification [25]. The functional form of this production function is

$$
A=\mu_{0}+\mu_{1} S+\mu_{2} \alpha+\mu_{3} Q+\varepsilon
$$

The parameter $\mu$ is the vector of the coefficients to be estimated and $\varepsilon$ the error term which captures the measurement errors of the variables $Q, S$ and $\alpha$. The quality of the school differs according to the type of school. Also, learning efficiency is 
also a multidimensional notion and can be influenced by several factors. The equation of acquisition of cognitive skills can then be rewritten in the form

$$
A=\mu_{0}+\mu_{1} S+\rho_{1} \alpha_{1}+\rho_{2} \alpha_{2}+\ldots+\rho_{n} \alpha_{n}+\tau_{1} Q_{1}+\tau_{2} Q_{2}+\ldots+\tau_{n} Q_{n}+\varepsilon
$$

The level of knowledge can be validly equated with the level of education. As a result, the level of education is explained by a set of variables relating to the school, its quality and its environment, the child, the parents, and the socioeconomic context.

\subsection{Econometric analysis model}

The empirical application of the educational demand model will be done using a multinomial qualitative variable model as in the study for the analysis of the demand for education in rural areas of Benin (see [28]). We first estimate the probability of being schooled using a logit model in which the variable of interest is a binary variable that takes the value 1 when the child is enrolled and 0 if not:

$$
\operatorname{logit}[\text { Enrol }=1]=\Phi\left(X_{I} \beta\right)
$$

where $\mathrm{X}_{\mathrm{i}}$ is a vector capturing the individual, family, and community characteristics that can influence the probability of a child going to school, $\beta$ is the vector of unknown parameters to estimate, and $\Phi($.$) is the normal cumulative distribution$ function. It is therefore necessary to estimate the probability of being educated conditionally to the explanatory variables transformed by the distribution function;

$$
P(Y=1 \mathrm{I} X)=\beta_{0}+\beta_{i} X_{i}+\beta_{m} X_{m}+\beta_{r} X_{r}+\varepsilon
$$

where $\left\{\begin{array}{l}X_{i}=\text { the individual characteristics of the child } \\ X_{m}=\text { socio-economic and demographic characteristics of the household } \\ X_{r}=\text { the characteristics of the place of residence of the household and the child } \\ \varepsilon=\text { term of error }\end{array}\right.$

In a second step, we estimate a multinomial model to capture the explanatory factors of the continuation of school life once children are enrolled:

$$
\operatorname{mlogit}[\text { School }=k]=\Phi\left(X_{I} \beta\right)
$$

with $\mathrm{k}=1,2$, and 3 corresponding, respectively, to primary, first, and second cycles of secondary school. It is a question of estimating the function $U_{i k}=X_{i} \beta_{k}+\varepsilon_{i k}$ where $\varepsilon_{i k}$ is an independent random variable and the individual characteristics of the child, those of the household, and the place of residence. The probability of choosing a category $\mathrm{k}$ is given by

$$
P\left(Y_{i}=k\right)=\frac{\exp \left(X_{i} \beta_{k}\right)}{\sum_{k^{\prime}=1}^{K} \exp \left(X_{i} \beta_{k^{\prime}}\right)}
$$

Household living standard survey data (ENV98 and ENV2008) will be used for applications. They provide information on the characteristics of households, their members, and their living environment. Each individual is attached to a household whose demographic structure and socioeconomic context are well-known. 


\section{Empirical evaluations}

We analyze the probability of being schooled using a binary logit model. Then we apply the multinomial logit to grasp the explanatory factors of the continuation of studies in the secondary cycle. The estimation technique is the maximum likelihood.

\subsection{Factors explaining the school decision}

The analysis of the determinants of schooling will be conducted according to individual characteristics, family determinants, and contextual elements (Table 1). We also calculate odds ratios (Table 2) and marginal effects (Table 3 ).

\subsubsection{Individual determinants}

The age of the child, his sex, and the relationship to the head of the household are the characteristics considered. Their influence on schooling has evolved over time. The age of the children acts positively in favor of schooling with an inverted U-shaped evolution as the age increases. The age thus has an inverted U-shaped effect on the education decision, thus joining the education decision in Benin [28].

Young boys are more likely to be in school. This confirms findings of other study taking account West African counties [29]. Girls are discriminated for schooling in some West African countries, including Côte d'Ivoire. It should be noted, however, that in 2008, the individual characteristics of the child were less important in his schooling than in 1998. His health status was of greater concern to his parents when it came to sending him to school.

\subsubsection{Family determinants}

Sociodemographic determinants such as household size and number of adults in the household have significant effects on children's schooling. In 1998, there was a positive correlation between the number of adults in a family and the schooling of children in that family. In 2008, the number of children under 5 is positively correlated with the school decision. But, the number of adults in the household discourages schooling. In addition, the number of educated adults in the household encourages the education of children. Children in a single-parent household are less likely than those in a couple to be in school.

The responsibility for educational expenses is not a barrier to schooling for children. However, parents with a primary level are not very favorable to schooling their children, while those who have not been to school are motivated to send their children to school. The socio-professional category of parent influences the education decision with greater for public employees compared to private sector employees and farmers.

\subsubsection{The contextual elements}

Membership in a social organization and the supply of education encourage the schooling of children. Membership in the association therefore has positive externalities on the probability of raising children. Also, bringing education supply to households encourages parents to send their children to school. In 2008, this influence of educational provision was reinforced by the availability of secondary education institutions in the region or department. When the nearest security office 


\begin{tabular}{|c|c|c|c|c|c|}
\hline \multicolumn{3}{|c|}{ ENV1998 } & \multicolumn{3}{|c|}{ ENV2008 } \\
\hline Enroll & Coef. & $\mathbf{z}$ & Enroll & Coef. & $\mathbf{z}$ \\
\hline \multicolumn{6}{|c|}{ Individual determinants } \\
\hline Age & $0.4497^{* *}$ & 2.23 & Age & -0.0255 & -0.46 \\
\hline age2 & $-0.0435^{* * *}$ & -5.41 & age2 & -0.0048 & -1.67 \\
\hline child_hh & -0.1733 & -0.80 & ChilGen & $-0.7186^{* * *}$ & -6.98 \\
\hline \multirow[t]{4}{*}{ ChilGen } & $0.7404^{* * *}$ & 4.79 & lchild11hh & -0.0173 & -0.41 \\
\hline & & & lchil12.15hh & $-0.3506^{* *}$ & -7.24 \\
\hline & & & lchil16.18hh & $-0.1219^{* *}$ & -2.43 \\
\hline & & & SickDur & $0.2689^{* * *}$ & 2.85 \\
\hline \multicolumn{6}{|c|}{ Family determinants $x$} \\
\hline Size_h & $-0.5694^{* * *}$ & -5.62 & Size_h & 0.1203 & 1.31 \\
\hline Sexhh & 0.21101 & 0.84 & Sexhh & $-0.9466^{* * *}$ & -5.75 \\
\hline SPC & -0.0138 & -0.42 & SPC & $-0.0942^{* *}$ & -2.17 \\
\hline non_ed_parh & $0.3623^{* * *}$ & 3.56 & matStahh & $0.9453^{* * *}$ & 6.70 \\
\hline Paredh & $-0.3267^{* * *}$ & -3.45 & Edupar & -0.0354 & -0.44 \\
\hline child_5h & $0.2926^{* * *}$ & 2.87 & child_5 & $0.3388^{* *}$ & 2.30 \\
\hline Mal19_59h & $0.3285^{* * *}$ & 3.40 & fem19_59 & $-0.3755^{* * *}$ & -3.31 \\
\hline fem19_59h & $0.3611^{* * *}$ & 4.06 & male19_59 & $-0.3406^{* * *}$ & -3.29 \\
\hline adult60h & $0.3148^{* *}$ & 2.08 & adult60 & $-0.3118^{*}$ & -1.69 \\
\hline An_rev_hh & $2.96 e-09$ & 0.72 & Revenu & $3.44 \mathrm{e}-08$ & 1.61 \\
\hline Respedh & $0.7403^{* * *}$ & 10.27 & Scolm & $0.21892^{*}$ & 1.78 \\
\hline Scolh & $0.2018^{* * *}$ & 4.65 & Child & $0.5492^{* * *}$ & 3.34 \\
\hline Migrant & -0.8082 & -1.33 & Migrant & 0.0108 & 1.20 \\
\hline Resid & 0.2481 & 1.23 & & & \\
\hline \multicolumn{6}{|c|}{ Contextual determinants } \\
\hline Associat & $0.3741^{* *}$ & 2.00 & Associat & -0.0628 & -0.47 \\
\hline Region & -0.0212 & -0.27 & coges_ape & $1.5506^{* * *}$ & 8.71 \\
\hline GdRegion & 0.0381 & 1.22 & Pu_sch & $1.3742^{* * *}$ & 14.55 \\
\hline Infracom & 0.0878 & 0.46 & Pr_sch & $1.2302^{* * *}$ & 13.17 \\
\hline Transp & 0.0945 & 0.57 & Ip_sch & -0.0557 & -0.24 \\
\hline PPSh & $0.7569^{* * *}$ & 9.61 & Is_sch & 0.0847 & 0.33 \\
\hline Gen_sch_hh & $0.1892^{*}$ & 1.79 & Admin & 0.0284 & 0.20 \\
\hline \multirow[t]{8}{*}{ _cons } & 2.1982 & 1.61 & Securit & -0.0152 & -0.06 \\
\hline & & & Infracom & $-5.33 e-08$ & -0.50 \\
\hline & & & D_infocom1 & -0.0920 & -0.67 \\
\hline & & & D_infocom & $0.2719^{* * *}$ & 3.85 \\
\hline & & & D_adm0 & $-0.1731^{* * *}$ & -3.17 \\
\hline & & & D_adm1 & $-0.2103^{* * *}$ & -4.99 \\
\hline & & & D_adm & $0.0324^{*}$ & 1.84 \\
\hline & & & D_securit1 & 0.0181 & 0.11 \\
\hline
\end{tabular}




\begin{tabular}{|c|c|c|c|c|c|}
\hline \multicolumn{3}{|c|}{ ENV1998 } & \multicolumn{3}{|c|}{ ENV2008 } \\
\hline \multirow[t]{6}{*}{ Enroll } & Coef. & $\mathbf{z}$ & Enroll & Coef. & $\mathbf{z}$ \\
\hline & & & D_securit & $-0.2295^{*}$ & -1.94 \\
\hline & & & D_prim & $-1.3031^{* * *}$ & -9.24 \\
\hline & & & D_second1 & -0.3276 & -0.99 \\
\hline & & & D_second & $-0.6560^{* * *}$ & -3.43 \\
\hline & & & _cons & $1.7753^{* * *}$ & 3.53 \\
\hline \multicolumn{3}{|c|}{ Number of observations $=3321$} & \multicolumn{3}{|c|}{ Number of observations $=3892$} \\
\hline \multicolumn{3}{|c|}{ LR $\operatorname{chi} 2(25)=1701.91$} & \multicolumn{3}{|c|}{ LR chi2 $(39)=1444.97$} \\
\hline \multicolumn{3}{|c|}{ Prob $>$ chi2 $=0.0000$} & \multicolumn{3}{|c|}{ Prob $>$ chi $2=0.0000$} \\
\hline \multicolumn{3}{|c|}{ Pseudo R2 = 0.5727} & \multicolumn{3}{|c|}{ Pseudo R2 = 0.4142} \\
\hline \multicolumn{3}{|c|}{ Log likelihood $=-634.85088$} & \multicolumn{3}{|c|}{ Log likelihood $=-1021.9515$} \\
\hline
\end{tabular}

*Significance at the threshold of $10 \%$

${ }^{* *}$ Significance at the threshold of $5 \%$.

${ }^{* * *}$ Significance at the threshold of $1 \%$.

Source: Author using data from ENV98 and ENV2008.

Table 1.

Results of the binary regression of the probability of schooling.

is located more than $5 \mathrm{~km}$ from the residence, parents are less motivated to enroll their children in school [30]. The presence of the administration acts positively on the schooling.

\subsubsection{Odds ratios}

The odds ratios allow appreciating the influence of the independent variables on the dependent variable in terms of percentage but are not elasticities. The difference between the displayed value and the unit gives the weight of this influence and its meaning (see Table 2).

In 1998, age acted positively on the school decision in more than $56 \%$ of cases. Gender is the determining factor in the child's own characteristics with a comparative advantage for young boys. The main determinant of schooling in 2008 is the state of health of the child. The marital status of the head of household and the presence of administrative services strongly contributed to the schooling of children in 2008 . The number of children under 5 is crucial for more than $40 \%$ of cases. The presence of adults frees children and increases their chance of attending school by more than $50 \%$ in 1998. On the other hand, the influence of the number of educated adults in the household is smaller than that of the number of adults even if it is positive. But 2008, the number of educated people in the household is an essential lever for schooling.

The supply of education and the responsibility for school expenses determine the decision to go to school in more than $80 \%$ of cases. The endowment of communication infrastructures greatly increases the probability of being in school.

\subsubsection{Marginal effects}

The marginal effects let us to assess the impact of the independent variables on the dependent variable (see Table 3). For example, in 1998, when the size of the household increased by $10 \%$, the motivation to enroll children dropped by $2 \%$. The probability of going to school increases by $2 \%$ from a girl to a boy. Also, the parents' membership of an association increases by $1.5 \%$ the chance of the children to be educated. In addition, the $10 \%$ increase in the supply of primary education increases 
ENV1998

ENV2008

\begin{tabular}{|c|c|c|c|c|c|}
\hline Enroll & Odds ratios & $\mathbf{z}$ & Enroll & Odds ratios & $\mathbf{z}$ \\
\hline \multicolumn{6}{|c|}{ Individual determinants } \\
\hline Age & $1.5678^{* *}$ & 2.23 & Age & 0.9748 & -0.50 \\
\hline age2 & $0.9575^{* * *}$ & -5.41 & age2 & $0.9952^{*}$ & -1.80 \\
\hline child_hh & 0.8409 & -0.80 & ChilGen & $0.4874^{* * *}$ & -9.46 \\
\hline \multirow[t]{4}{*}{ ChilGen } & $2.0967^{* * *}$ & 4.79 & lchild11hh & 0.9828 & -0.54 \\
\hline & & & lchil12.15hh & $0.7042^{* * *}$ & -9.52 \\
\hline & & & lchil16.18hh & $0.8852^{* * *}$ & -3.31 \\
\hline & & & SickDur & $1.3086^{* * *}$ & 2.92 \\
\hline \multicolumn{6}{|c|}{ Family determinants } \\
\hline Size_h & $0.5659^{* * *}$ & -5.62 & Size_h & $1.1279^{*}$ & 1.91 \\
\hline Sexhh & 1.2349 & 0.84 & Sexhh & $0.3881^{* * *}$ & -6.58 \\
\hline SPC & 0.9863 & -0.42 & SPC & $0.9101^{* *}$ & -2.30 \\
\hline non_ed_parh & $1.4366^{* * *}$ & 3.56 & matStahh & $2.5736^{* * *}$ & 6.57 \\
\hline Paredh & $0.7213^{* * *}$ & -3.45 & Edupar & 0.9652 & -0.39 \\
\hline child_5h & $1.3399^{* * *}$ & 2.87 & child_5 & $1.4033^{* * *}$ & 2.88 \\
\hline Mal19_59h & $1.3889^{* * *}$ & 3.40 & fem19_59 & $0.6869^{* * *}$ & -3.91 \\
\hline fem19_59h & $1.4349^{* * *}$ & 4.06 & male19_59 & $0.7114^{* * *}$ & -3.96 \\
\hline adult60h & $1.3700^{* *}$ & 2.08 & adult60 & $0.7322^{*}$ & -1.83 \\
\hline An_rev_hh & 1.0000 & 0.72 & Revenu & 1.0000 & 1.53 \\
\hline Respedh & $2.0966^{* * *}$ & 10.27 & Scolm & 1.2447 & 1.35 \\
\hline Scolh & $1.2236^{* * *}$ & 4.65 & Child & $1.7318^{* * *}$ & 3.64 \\
\hline Migrant & 0.4457 & -1.33 & Migrant & 1.0101 & 1.07 \\
\hline Resid & 1.2816 & 1.23 & & & \\
\hline \multicolumn{6}{|c|}{ Contextual determinants } \\
\hline Associat & $1.4537^{* *}$ & 2.00 & Associat & 0.9391 & -0.47 \\
\hline Region & 0.9790 & -0.27 & coges_ape & $4.7142^{* * *}$ & 10.45 \\
\hline GdRegion & 1.0389 & 1.22 & Pu_sch & $3.9519^{* * *}$ & 18.04 \\
\hline Infracom & 1.0918 & 0.46 & Pr_sch & $3.4219^{* * *}$ & 13.85 \\
\hline Transp & 1.0992 & 0.57 & Ip_sch & 0.9458 & -0.21 \\
\hline PPSh & $2.1316^{* * *}$ & 9.61 & Is_sch & 1.0883 & 0.34 \\
\hline Gen_sch_hh & $1.2083^{*}$ & 1.79 & Admin & 1.0288 & 0.20 \\
\hline \multirow[t]{8}{*}{ _cons } & 9.0084 & 1.61 & Securit & 0.9849 & -0.06 \\
\hline & & & Infracom & 0.9999 & -0.73 \\
\hline & & & D_infocom1 & 0.9121 & -0.75 \\
\hline & & & D_infocom & $1.3124^{* * *}$ & 3.91 \\
\hline & & & D_adm0 & $0.8411^{* * *}$ & -3.33 \\
\hline & & & D_adm1 & $0.8104^{* * *}$ & -4.63 \\
\hline & & & D_adm & 1.0329 & 1.59 \\
\hline & & & D_securit1 & 1.0183 & 0.12 \\
\hline
\end{tabular}




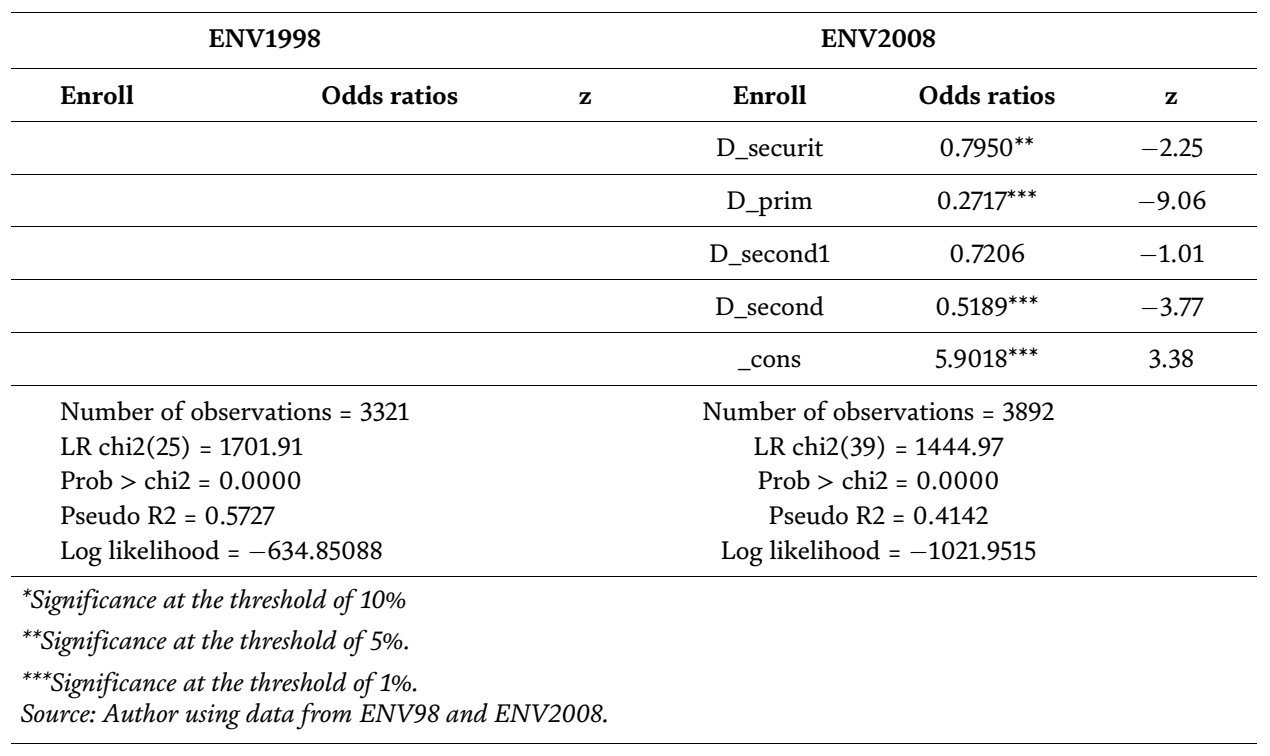

Table 2.

The odds ratios.

enrollment by almost 3\%, compared with $7 \%$ points for supply of secondary education. The presence of a secondary school in the locality increases by $0,21 \%$ the probability of being educated against 0,09\% for the administration. Being a direct descendant of the household head increases the chance of being in school.

In 2008, a $10 \%$ increase in the number of children in the household led to a $3 \%$ increase in the probability of being in school. Similarly, the increase in the number of children under 5 by $10 \%$ increases the chances of attending school by $1.9 \%$. This influence is $5.3 \%$ when moving from a single-parent household to a couple. A $10 \%$ increase, respectively, in public and private education offers increases the probability of attending school by 7.7 and $6.9 \%$. The existence of a COGES improves this probability by $7.48 \%$. In contrast, an additional adult in the household reduces the probability of attending school by 2.11 or $1.92 \%$ depending on whether a woman or a man is between 19 and 59 years old.

An extension of $1 \mathrm{~km}$ of distance to the nearest administration causes a decrease of $1.18 \%$ in the probability of being in school compared to $1.29 \%$ for the security services and $10.67 \%$ for the primary school against not more than $3.7 \%$ for the secondary establishment.

\subsection{Determinants of the continuation of educational life in the secondary cycle}

The analysis of the determinants of the pursuit of education follows the same logic as that of the explanatory factors of schooling (Table 4).

\subsubsection{Individual determinants}

In 1998, the age of the child is the only significant individual variable for continuing high school education. Younger children are much more likely to go to high school. This is in line with the findings of the case study on Benin [28] that the likelihood of continuing education declines as the child approaches the end of childhood.

In 2008, it is rather the relationship with the head of household that becomes determinant for secondary school. Also, a significant number of children of primary 


\begin{tabular}{|c|c|c|c|c|c|}
\hline \multicolumn{3}{|c|}{ 1998: $y=\operatorname{Pr}($ enroll $)($ predict $)=0.9606$} & \multicolumn{3}{|c|}{ 2008: $y=\operatorname{Pr}($ enroll $)($ predict $)=0.9400$} \\
\hline Variables & $\mathrm{dy} / \mathrm{dx}$ & $\mathbf{z}$ & Variables & $\mathrm{dy} / \mathrm{dx}$ & $\mathbf{z}$ \\
\hline \multicolumn{6}{|l|}{ Individual } \\
\hline Age & $0.0170^{* *}$ & 1.98 & Age & -0.0014 & -0.50 \\
\hline age2 & $-0.0016^{* * *}$ & -4.10 & age2 & $-0.0003^{*}$ & -1.77 \\
\hline child_hh & -0.0066 & -0.83 & ChilGen & $-0.0405^{* * *}$ & -9.14 \\
\hline \multirow[t]{4}{*}{ ChilGen* } & $0.0297^{* * *}$ & 4.41 & lchild11hh & -0.0010 & -0.54 \\
\hline & & & lchil12.15hh & $-0.0198^{* * *}$ & -8.69 \\
\hline & & & lchil16.18hh & $-0.0069^{* * *}$ & -3.24 \\
\hline & & & SickDur & $0.0152^{* * *}$ & 2.92 \\
\hline \multicolumn{6}{|l|}{ Family } \\
\hline Size_h & $-0.0215^{* * *}$ & -4.68 & Size_h & $0.0067842^{*}$ & 1.90 \\
\hline Sexhh & 0.0080 & 0.87 & Sexhh & $-0.0534^{* * *}$ & -6.63 \\
\hline SPC & -0.0005 & -0.44 & SPC & $-0.0053^{* *}$ & -2.28 \\
\hline non_ed_parh & $0.0137^{* * *}$ & 3.24 & matStahh & $0.0533^{* * *}$ & 6.17 \\
\hline Paredh & $-0.0123^{* * * *}$ & -3.27 & Edupar & -0.0020 & -0.39 \\
\hline child_5h & $0.0111^{* *}$ & 2.59 & child_5 & $0.0191^{* * *}$ & 2.87 \\
\hline Mal19_59h & $0.0124^{* * *}$ & 3.36 & fem19_59 & $-0.0212^{* * *}$ & -3.90 \\
\hline fem19_59h & $0.0137^{* * *}$ & 3.93 & male19_59 & $-0.0192^{* * *}$ & -3.92 \\
\hline adult60h & $0.0119^{* *}$ & 2.15 & adult60 & $-0.0176^{*}$ & -1.83 \\
\hline An_rev_hh & $1.12 \mathrm{e}-10$ & 0.88 & Revenu & $1.94 \mathrm{e}-09$ & 1.54 \\
\hline Respedh & $0.0280^{* * *}$ & 8.76 & Scolm & 0.0123 & 1.35 \\
\hline Scolh & $0.0076^{* * *}$ & 4.24 & Child* $^{*}$ & $0.0317^{* * *}$ & 3.53 \\
\hline Migrant* & -0.0434 & -0.84 & Migrant & 0.0006 & 1.08 \\
\hline resid & 0.0094 & 1.21 & & & \\
\hline \multicolumn{6}{|l|}{ Contextual } \\
\hline associat ${ }^{*}$ & $0.0157^{*}$ & 1.71 & associat* & -0.0036 & -0.47 \\
\hline region & -0.0008 & -0.27 & coges_ape* & $0.0748^{* * *}$ & 10.20 \\
\hline GdRegion & 0.0014 & 1.25 & $\mathrm{Pu} \_\mathrm{Sch}$ & $0.07748^{* * *}$ & 15.46 \\
\hline infracom* & 0.0032 & 0.47 & Pr_Sch & $0.0694^{* * *}$ & 12.20 \\
\hline transp* & 0.0036 & 0.57 & Ip_Sch* & -0.0032 & -0.21 \\
\hline PPSh & $0.0286^{* * *}$ & 8.18 & Is_Sch* & 0.0046 & 0.35 \\
\hline \multirow[t]{9}{*}{ Gen_sch_hh } & $0.0072^{*}$ & 1.70 & admin* & 0.0016 & 0.20 \\
\hline & & & securit* & -0.0009 & -0.06 \\
\hline & & & info_com & $-3.00 \mathrm{e}-09$ & -0.73 \\
\hline & & & D_infocom1 & -0.0052 & -0.75 \\
\hline & & & D_infocom & $0.0153^{* * *}$ & 3.88 \\
\hline & & & D_adm0 & $-0.0098^{* * *}$ & -3.30 \\
\hline & & & D_adm1 & $-0.0118^{* * *}$ & -4.53 \\
\hline & & & D_adm & 0.0018 & 1.59 \\
\hline & & & D_securit1 & 0.0010 & 0.12 \\
\hline
\end{tabular}


Discrete Choice Model: An Application to the Educational Decision of Ivorian Households DOI: http://dx.doi.org/10.5772/intechopen.87433

\begin{tabular}{|c|c|c|c|c|c|}
\hline \multicolumn{3}{|c|}{ 1998: $y=\operatorname{Pr}($ enroll $)($ predict $)=0.9606$} & \multicolumn{3}{|c|}{ 2008: $y=\operatorname{Pr}($ enroll $)$ (predict $)=0.9400$} \\
\hline \multirow[t]{5}{*}{ Variables } & $\mathrm{dy} / \mathrm{dx}$ & $\mathbf{z}$ & Variables & $\mathrm{dy} / \mathrm{dx}$ & $\mathbf{z}$ \\
\hline & & & D_securitt & $-0.0129^{* *}$ & -2.24 \\
\hline & & & D_prim* & $-0.1062^{* * *}$ & -6.48 \\
\hline & & & D_second $1^{*}$ & -0.0210 & -0.90 \\
\hline & & & D_second & $-0.0370^{* * *}$ & -3.79 \\
\hline \multicolumn{6}{|c|}{ *Significance at the threshold of $10 \% . d y / d x$ is for dummy variable changes from 0 to 1 for discrete variables. } \\
\hline \multicolumn{6}{|c|}{${ }^{* *}$ Significance at the threshold of $5 \%$. } \\
\hline \multicolumn{6}{|c|}{${ }^{* * *}$ Significance at the threshold of $1 \%}$. \\
\hline
\end{tabular}

Table 3.

The marginal effects of exogenous variables on the probability of schooling.

school and primary school age have a negative effect on entry to secondary school. On the other hand, a large number of children of upper secondary age who are directly related to the head of household increases the chances of attending secondary school. The first may serve as a guide or framer to the latter. This increases their "learning efficiency" (see [25]) and reduces the cost of education related to repetition. Good health is also important for high school.

\subsubsection{Family characteristics}

The number of adults in the household is inversely related to the continuation of secondary education. In addition, children of couples are more likely to have a full secondary education compared to single-parent families.

In 1998, residency status had a positive effect on secondary education, and migrant status had a negative influence. On the other hand, in 2008, migrations were positively correlated with secondary education. In our database, the main reasons declared to justify the migration of populations are related to education, professional reasons, and the crisis. Most of the displaced pupils have returned to school in their new places of residence thanks to certain facilities (relay school), hence the strong correlation between internal displacement and secondary education in 2008.

In addition, the increase in household size negatively influences children's chances of attending secondary school. On the other hand, the increase in household income has a very positive impact on the continuation of secondary education.

\subsubsection{The contextual elements}

Populations in the western forest region and in the central and northern savannah regions are those whose offspring are less likely to be in high school compared to families in the Abidjan region. The high labor demand for field work in these cash crop production areas may explain the fact that children over 12 years of age are removed from school to assist in plantations. Also, migration flows from central and northern populations to forest areas reduce the available labor force in the departure areas. Thus, the greatest children are regularly asked for the cultivation of the fields.

The fact that parents belong to an association or a union increases children's chance for secondary education in 1998. On the other hand, in 2008, associative activism (union, COGES, etc.) discourages further education in secondary education. In fact, the often high level of contributions in these associations is in competition with educational expenditure. This reduces the shares of income devoted to 


\begin{tabular}{|c|c|c|c|c|c|}
\hline \multicolumn{3}{|c|}{ ENV1998 } & \multicolumn{3}{|c|}{ ENV2008 } \\
\hline School & Coef. & $\mathbf{z}$ & School & Coef. & $\mathbf{z}$ \\
\hline \multicolumn{6}{|l|}{ Non-educated } \\
\hline \multicolumn{6}{|c|}{ Individual determinants } \\
\hline Age & $-0.5810^{* * *}$ & -2.96 & Age & -0.0174 & -0.40 \\
\hline age2 & $0.0496^{* * *}$ & 6.22 & age2 & 0.0016 & 0.69 \\
\hline child_hh & 0.0495 & 0.25 & ChilGen & 0.0416 & 0.66 \\
\hline \multirow[t]{4}{*}{ ChilGen } & $-0.7483^{* * *}$ & -5.15 & lchild11hh & 0.0095 & 0.34 \\
\hline & & & lchil12.15hh & $0.1867^{* * *}$ & 5.61 \\
\hline & & & lchil16.18hh & $0.5134^{* * *}$ & 14.43 \\
\hline & & & SickDur & $0.4265^{* * *}$ & 5.75 \\
\hline \multicolumn{6}{|c|}{ Family determinants } \\
\hline Size_h & $0.6085^{* * *}$ & 5.65 & Size_h & 0.0061 & 0.10 \\
\hline Sexhh & -0.2162 & -0.95 & Sexhh & $0.2879^{* *}$ & 2.23 \\
\hline SPC & 0.0032 & 0.10 & SPC & 0.0338 & 0.95 \\
\hline non_ed_parh & $-0.3864^{* * *}$ & -3.69 & matStahh & $-0.7316^{* * *}$ & -4.50 \\
\hline Paredh & $0.2948^{* * *}$ & 3.14 & Edupar & 0.0704 & 0.92 \\
\hline child_5h & $-0.3904^{* * *}$ & -3.62 & child_5 & 0.1221 & 1.26 \\
\hline Mal19_59h & $-0.3511^{* * *}$ & -4.06 & fem19_59 & $-0.3342^{* * *}$ & -3.76 \\
\hline fem19_59h & $-0.4244^{* * *}$ & -5.00 & male19_59 & 0.0262 & 0.32 \\
\hline adult60h & $-0.3922^{* * *}$ & -2.76 & adult60 & $0.31547^{* *}$ & 2.12 \\
\hline An_rev_hh & $-9.69 e-11$ & -0.03 & Revenu & $3.17 \mathrm{e}-08^{* *}$ & 2.17 \\
\hline Respedh & $-0.7886^{* * *}$ & -11.99 & Scolm & $-0.5934^{* * *}$ & -3.58 \\
\hline Scolh & $-0.1817^{* * *}$ & -4.42 & Child & $-0.5354^{* * *}$ & -4.15 \\
\hline Migrant & 0.6688 & 1.05 & Migrant & $0.0385^{* * *}$ & 4.73 \\
\hline Resid & -0.2304 & -1.21 & & & \\
\hline \multicolumn{6}{|c|}{ Contextual determinants } \\
\hline Associat & $-0.3258^{*}$ & -1.74 & associat & $-0.5917^{* * *}$ & -4.88 \\
\hline Regions & & & coges_ape & $0.3105^{* * *}$ & 2.72 \\
\hline Other cities & -0.0931 & -0.41 & $\mathrm{Pu} \_\mathrm{Sch}$ & $-1.089^{* * *}$ & -16.86 \\
\hline Forest East & -0.1325 & -0.46 & Pr_Sch & $-0.5735^{* * *}$ & -7.93 \\
\hline Forest west.t & -0.0074 & -0.03 & Ip_Sch & -0.1013 & -0.46 \\
\hline Savannah & -0.0730 & -0.21 & Is_Sch & 0.0280 & 0.13 \\
\hline GdRegion & -0.0226 & -0.69 & admin & 0.0857 & 0.71 \\
\hline infracom & 0.0322 & 0.19 & securit & 0.2033 & 0.86 \\
\hline Transp & -0.0599 & -0.38 & infracom & $-1.11 \mathrm{e}-08$ & -0.15 \\
\hline PPSh & $-0.7175^{* * *}$ & -10.54 & D_infocom1 & -0.0748 & -0.75 \\
\hline Gen_sch_hh & $-0.3734^{* * *}$ & -3.13 & D_infocom & $-0.1631^{* * *}$ & -3.51 \\
\hline \multirow[t]{3}{*}{ _cons } & -1.1867 & -0.92 & D_adm0 & $0.1401^{* * *}$ & 3.07 \\
\hline & & & D_adm1 & $0.1295^{* * *}$ & 3.53 \\
\hline & & & D_adm & $0.0820^{* * *}$ & 4.72 \\
\hline
\end{tabular}


Discrete Choice Model: An Application to the Educational Decision of Ivorian Households DOI: $h$ ttp://dx.doi.org/10.5772/intechopen.87433

\begin{tabular}{|c|c|c|c|c|c|}
\hline \multicolumn{3}{|c|}{ ENV1998 } & \multicolumn{3}{|c|}{ ENV2008 } \\
\hline School & Coef. & $\mathbf{z}$ & School & Coef. & $\mathbf{z}$ \\
\hline & & & D_securit1 & 0.2020 & 1.60 \\
\hline & & & D_securit & 0.1211 & 1.54 \\
\hline & & & D_prim & $1.2777^{* * *}$ & 10.33 \\
\hline & & & D_second1 & $-0.6889^{* * *}$ & -3.09 \\
\hline & & & D_second & $-0.2969^{* *}$ & -2.06 \\
\hline & & & _cons & -0.1052 & -0.21 \\
\hline Prim_School & Basis line & & & & \\
\hline \multicolumn{6}{|l|}{ Second_School } \\
\hline \multicolumn{6}{|c|}{ Individual determinants } \\
\hline Age & $1.6447^{* * *}$ & 2.70 & Age & -0.071788 & -1.49 \\
\hline age2 & -0.0222 & -1.06 & age2 & $0.005174^{* *}$ & 2.09 \\
\hline child_hh & -0.1549 & -0.83 & ChilGen & $-0.1177127^{*}$ & -1.81 \\
\hline \multirow[t]{4}{*}{ gendchil } & 0.1433 & 0.99 & lchild11hh & $-0.1111^{* * *}$ & -4.01 \\
\hline & & & lchil12.15hh & 0.0496 & 1.58 \\
\hline & & & lchil16.18hh & $0.4325^{* * *}$ & 12.78 \\
\hline & & & SickDur & 0.0910 & 1.09 \\
\hline \multicolumn{6}{|c|}{ Family determinants } \\
\hline Size_h & 0.0064 & 0.07 & Size_h & $-0.1583^{* * *}$ & -3.04 \\
\hline Sexhh & 0.0898 & 0.40 & Sexhh & $0.4011^{* * *}$ & 2.94 \\
\hline SPC & -0.0284 & -0.74 & SPC & -0.0137 & -0.38 \\
\hline non_ed_parh & 0.1008 & 1.07 & matStahh & -0.2796 & -1.54 \\
\hline Paredh & 0.1421 & 1.56 & Edupar & 0.1152 & 1.63 \\
\hline child_5h & 0.0131 & 0.14 & child_5 & -0.0066 & -0.07 \\
\hline Mal19_59h & $-0.3441^{* * *}$ & -4.02 & fem19_59 & -0.0019 & -0.02 \\
\hline fem19_59h & $-0.1421^{*}$ & -1.69 & male19_59 & $0.1347^{*}$ & 1.83 \\
\hline adult60h & -0.1203 & -0.83 & adult60 & $0.8167^{* * *}$ & 5.83 \\
\hline An_rev_hh & $5.82 \mathrm{e}-09^{*}$ & 1.83 & Revenu & $-6.29 \mathrm{e}-08^{* * *}$ & -4.36 \\
\hline Respedh & 0.0204 & 0.61 & Scolm & 0.0435 & 0.29 \\
\hline Scolh & $-1.3133^{*}$ & -1.89 & Child & $0.5782^{* * *}$ & 4.12 \\
\hline Migrant & 0.3394 & 1.64 & Migrant & $0.0654^{* * *}$ & 7.80 \\
\hline Resid & $-0.8711^{* * *}$ & -10.52 & & & \\
\hline \multicolumn{6}{|c|}{ Contextual determinants } \\
\hline Associat & 0.16534 & 1.03 & associat & $-0.2192^{*}$ & -1.69 \\
\hline Regions: & & & coges_ape & $-0.5885^{* * *}$ & -4.59 \\
\hline autres villes & -0.3615 & -1.57 & $\mathrm{Pu} \_\mathrm{Sch}$ & $0.2840^{* * *}$ & 5.24 \\
\hline Forêt Est & $-0.7284^{* *}$ & -2.23 & Pv_Sch & $0.37748^{* * *}$ & 5.93 \\
\hline Forêt Ouest & $-0.7140^{* *}$ & -2.34 & Ip_Sch & 0.0013 & 0.01 \\
\hline Savane & $-0.8853^{* *}$ & -2.11 & Is_Sch & -0.0202 & -0.09 \\
\hline GdRegion & -0.0381 & -1.07 & admin & 0.0370 & 0.28 \\
\hline
\end{tabular}




\begin{tabular}{|c|c|c|c|c|c|}
\hline \multicolumn{3}{|c|}{ ENV1998 } & \multicolumn{3}{|c|}{ ENV2008 } \\
\hline School & Coef. & $\mathbf{z}$ & School & Coef. & $\mathbf{z}$ \\
\hline infracom & 0.2844 & 1.40 & securit & $0.5716^{* *}$ & 2.39 \\
\hline Transp & -0.2222 & -1.40 & infracom & $1.81 \mathrm{e}-07^{* * *}$ & 2.71 \\
\hline EPPm & $0.2190^{* * *}$ & 3.18 & D_infocom1 & $-0.4196^{* * *}$ & -2.82 \\
\hline Ets_gén_pcm & $0.6429^{* * *}$ & 7.52 & D_infocom & $0.1293^{* * *}$ & 3.12 \\
\hline \multirow[t]{9}{*}{ _cons } & $-19.6011^{* * *}$ & -4.41 & D_adm0 & 0.0525 & 1.09 \\
\hline & & & D_adm1 & $0.1611^{* * *}$ & 3.61 \\
\hline & & & D_adm & $0.0913^{* * *}$ & 5.19 \\
\hline & & & D_securit1 & -0.1474 & -0.92 \\
\hline & & & D_securit & -0.1244 & -1.45 \\
\hline & & & D_prim & $1.1673^{* * *}$ & 7.97 \\
\hline & & & D_second1 & -0.2504 & -1.21 \\
\hline & & & D_second & $-1.4441^{* * *}$ & -9.24 \\
\hline & & & _cons & $-1.9054^{* * *}$ & -3.55 \\
\hline \multicolumn{3}{|c|}{ Number of observations $=4055$} & \multicolumn{3}{|c|}{ Number of observations $=3964$} \\
\hline \multicolumn{3}{|c|}{ Wald chi2 $(56)=1179.88$} & \multicolumn{3}{|c|}{ LR $\operatorname{chi} 2(78)=2605.07$} \\
\hline \multicolumn{3}{|c|}{ Prob $>$ chi $2=0.0000$} & \multicolumn{3}{|c|}{ Prob $>$ chi2 $=0.0000$} \\
\hline \multicolumn{3}{|c|}{ Pseudo $\mathrm{R} 2=0.5862$} & \multicolumn{3}{|c|}{ Pseudo R2 = 0.3473} \\
\hline \multicolumn{3}{|c|}{ Pseudo log likelihood $=-1408.2873$} & \multicolumn{3}{|c|}{ Pseudo log likelihood $=-2447.6977$} \\
\hline \multicolumn{6}{|c|}{ *Significance at the threshold of $10 \%$} \\
\hline \multicolumn{6}{|c|}{ **Significance at the threshold of 5\%. } \\
\hline \multicolumn{6}{|c|}{$\begin{array}{l}{ }^{* * *} \text { Significance at the threshold of } 1 \% . \\
\text { Source: Author using data from ENV98 and ENV2008. }\end{array}$} \\
\hline
\end{tabular}

Table 4.

Results of multinomial regressions.

education hence the inverse relationship between belonging to an association and the chances of going to secondary school in 2008.

Also, the presence of secondary schools is beneficial for the continuity of studies. This positive relationship between the supply of education and the probability of attending secondary school is reinforced by the presence of communication infrastructures and the reduction of distances to the first educational, security, and administrative infrastructure (see [30]).

\section{Conclusion}

This study aims to elucidate the factors that underlie the decision of households to invest in the education of their children from the Ivorian case. It is an application of the multinomial logit model using data from the living standards surveys of 1998 and 2008.

The findings show that in Côte d'Ivoire the age of the children, composition of the household, as well as education supply (the probability of being able to go to secondary school combined with the proximity of primary schools) are the factors that motivate parents to enroll their children in primary school. For the continuation of studies at the secondary level, the level of income is very decisive.

Sociodemographic factors also play a very important role, such as the size and 
composition of the household as well as the sex of the head of the household and the type of household. Also, children entering high school are more likely to continue their studies. However, from one region to another, disparities can be observed according to the sex of the child and the socio-professional category of the head of the household.

Bridging the security services encourages education mostly secondary despite the distance to the nearest school. The presence of the administration or its bringing together of citizens and the development of communication and transport infrastructures reinforce the attractiveness of the school in Côte d'Ivoire. However, some school management structures, such as COGES, tend to reduce school life, especially at the secondary level.

In addition, considering the endogenous quality of education provision will make the results of the study more robust. To do this, it is necessary to gather information on the characteristics of the educational offer, particularly the number of pupils per teaching, the actual execution of the school curriculum, the provision of teaching materials for training structures, etc. Also, considering the decisionmaking mechanism within households makes it possible to better identify the sociodemographic factors that influence the decision to educate households. The availability of information on the above variables is an extension of this study.

\section{Author details}

N'da Koffi Christan

Université Jean Lorougnon Guédé, Daloa, Côte d'Ivoire

*Address all correspondence to: nda.christian@gmail.com; nda.christian@ujlg.edu.ci

\section{IntechOpen}

(C) 2020 The Author(s). Licensee IntechOpen. This chapter is distributed under the terms of the Creative Commons Attribution License (http://creativecommons.org/licenses/ by/3.0), which permits unrestricted use, distribution, and reproduction in any medium, provided the original work is properly cited. (c) BY 


\section{References}

[1] Mankiw NG, Romer D, Weil DN. A contribution to the empirics of economic growth. The Quarterly Journal of Economics. 1992;107(2):407-437

[2] Lucas R. On the mechanics of economic development. Journal of Monetary Economics. 1988;22(11):3-42

[3] Aghion P, Howitt P. The Economics of Growth. Paris: Economica; 2010

[4] PRSP. Poverty Reduction Strategy Paper of Côte d'Ivoire. January 2009. http://www.gouv.ci/doc/DSRP_FINAL \%20RCI_Def.pdf

[5] UNESCO. United Nations Creative Economy Report, Special Edition. Paris: UNESCO; 2013

[6] Simonnet V. Mobilité professionnelle. In: Dictionnaire du Travail. Vol. 1. Quadrige, PUF; 2012. pp. 479-485

[7] Mincer J. Schooling, Experience and Earnings. New York: MColumbia University Press; 1974

[8] Coulombe S, Tremblay JF. Literacy and growth. Topics in Macroeconomics. Art. 4. 2006;6(2):1-32. DOI: 10.2202/ 1534-5998.1404

[9] Baumol WJ. Productivity growth, convergence and welfare: What the long-run data show. The American Economic Review. 1986;76(15): 1072-1085

[10] Barro R, Sala-i-Martin X. Public finance in models of economic growth. The Review of Economic Studies. 1992; 59(14):645-661

[11] Romer, Paul M. Human capital and growth: Theory and evidence. No. w3173. National Bureau of Economic Research. 1989. https://www.nber.org/ papers/w3173.pdf
[12] Edgard BC. Investing in human capital: Integrating intellectual capital architecture and utility theory. The Journal of Human Resource and Adult Learning. 2010;6(1):1-29

[13] Balestrino A. Education policy in a non-altruistic model of intergenerational transfers with endogenous fertility. European Journal of Political Economy. 1997;13(11):157-169

[14] Acemoglu D. Public policy in a model of long-term unemployment. Economica. 1995;62:161-178

[15] Cremer HD, Pestieau P. Intergenerational transfers within the family. European Economic Review. 1992;36(11):1-16

[16] Bahram V, Boadway R, Marchand M, Pestieau P. Education and the poverty trap. European Economic Review. 1995;39(17):1257-1275

[17] Bolduc D. Generalized autoregressive errors in the multinomial probit model. Transportation Research Part B: Methodological. 1992;26(12): 155-170

[18] Psacharopoulos G. Returns to Investment in Education: A global update. In: World Bank Policy Research Working Paper, WPS 1067. 1993

[19] Guillotin Y, Sevestre P. Estimations de fonctions de gains sur données de panel: Endogénéité du capital humain et effets de la sélection. Économie et Prévision. 1994;1116:119-135

[20] Fredriksson P. Economic incentives and the demand for higher education. Scandinavian Journal of Economics. 1997;99(11):129-142

[21] Keane MP, Wolpin KI. The career decisions of young men. Journal of Political Economy. 1997;105(13):473-522 
[22] Becker GS. Human Capital. Chicago: Chicago Press; 1964

[23] Becker GS. Investment in human capital: Effects on earnings. In: Human Capital: A Theoretical and Empirical Analysis, with Special Reference to Education. 2nd ed. Vol. 2. NBER; 1975. pp. $13-44$

[24] Becker GS. The economic way of looking at behavior. Journal of Political Economy. 1993;101(13):385-409

[25] Glewwe P. Schools and skills in developing countries: Education policies and socioeconomic outcomes. Journal of Economic Literature. 2002;40(12): 436-482

[26] Glewwe P. Using Maimonides' rule to estimate the effect of class size on scholastic achievement. Quarterly Journal of Economics. 1999;114(12): 533-575

[27] Glewwe P. New Evidence on Classroom Computers and Pupil Learning. NBER Working Paper. Vol. 74241999b

[28] Chabi O, Attanasso MO.

Déterminants de la scolarisation et niveau scolaire en milieu rural: Une étude empirique au Bénin en Afrique de l'Ouest. International Journal of Innovation and Applied Studies. 2015; 10(11):73-84

[29] Durand MH. Les enfants non scolarisés en milieu urbain: Une comparaison des déterminants intra familiaux, inters familiaux et des effets de voisinage dans sept capitales ouest africaines. In: DIAL, Document de Travail. Vol. DT2006. No. 102. 2006

[30] Grira H. Capital humain au Bangladesh [thèse de Doctorat en Sciences Economiques]. Paris: Université de Paris I-Panthéon Sorbonne; 2006 



\title{
Mathematics Education System in South Africa
}

\author{
Zingiswa Jojo
}

\begin{abstract}
The teaching of mathematics in South African schools has been pronounced to be among the worst in the world. Unacknowledged poor teaching of mathematics in a majority of public schools deprive many learners access to both higher education and modern, knowledge-intensive work skills. The chapter resumes by outlining mathematics curriculum redress and changes in the post-apartheid era, the exploration of mathematics education, democracy and development, together with the introduction of Mathematical Literacy as an alternative compulsory subject to learners incompetent to do mathematics. The chapter further interrogates how mathematics education, in terms of mathematical knowledge, skills, values and attitudes, is distributed in society and thereby shapes educational possibilities together with the research trends and their effect on mathematics education in South Africa. Mathematics teacher training and empowerment are discussed together with shortcomings in the system that leads to learners' poor performance in Mathematics. How South Africa compares in performance with other countries is also examined in this chapter. The closing remarks of the chapter suggest some improvements that the mathematics education system in South Africa can embark on.
\end{abstract}

Keywords: mathematics education, mathematics curriculum, mathematical literacy, mathematics knowledge, democracy, research, development

\section{Introduction}

There has been a significant reform in the South African mathematics curriculum such that the mathematics education research community has also grown markedly. The trust and focus of this chapter is to unpack the mathematics education system in South Africa in the post-apartheid era. The author draws and builds envisaged result bearing changes in the system in the country from various scholars. The curriculum reform in South Africa has been generally political driven. Consequently, the country has experienced reduction of education for the past 20 years to, economic ends, coupled with the conflation between mathematical prowess and problem-solving skills for the knowledge economy, which has resulted in mathematics being isolated as essential knowledge in South Africa. Thus in the post-apartheid era in the country, a redress was effected to ensure that all students will have been exposed to some form of mathematics by the time they complete matric.

After the 1994 democratic elections and post elections in South Africa, many changes took place and the biggest change by necessity has been in the area of education. Initially, curriculum 2005 (C2005) which was driven by the Outcomes Based Education (OBE) was unveiled by the department of basic education. It was 
mainly characterized by cooperative group instruction which made it difficult for teachers to identify struggling learners in mathematics understanding at all levels. Outcomes-based education was introduced in 1997 to overcome the curricular divisions of the past, and was reviewed in 2000 after the experience of its implementation by stakeholders yielded bad results [1]. The Revised National Curriculum Statement (RCNS) Grades R-9 and the National Curriculum Statement Grades 10-12 was then implemented in 2002. Consequently, according to [2] the RNCS system failed because the educators did not understand it and quite often did not see the difference between C2005 and the RCNS. The result was that the implementation challenges of RCNS were the same as those of C2005 [2]. It also transpired that RCNS was highly loaded and fell short of its expectations, used vague complex terminology and inadequate training of teachers and district officials. In 2012 it was reviewed again and replaced by the Curriculum and Assessment Policy Statement (CAPS) which was rolled out in all phases. According to the authors [3], OBE is still the underlying philosophy which underpins CAPS. Currently, CAPS is the curriculum practiced in the country as a measure that redresses the inequalities and imbalances of the past. With effect from January 2012, a single comprehensive Curriculum and Assessment Policy Statement was developed for each subject to replace Subject Statements, Learning Programme Guidelines and Subject Assessment Guidelines in Grades R-12.

CAPS in general aims to produce learners that are able to:

- use critical and creative thinking in making decisions of identification and solution of problems;

- work effectively as individuals and with others as members of a team;

- manage and organize themselves in handling their activities responsibly and effectively;

- collect, analyze, organize and critically evaluate relevant data;

- use visual, symbolic and/or language skills in various modes to communicate effectively; and

- recognize that problem-solving contexts do not exist in isolation and demonstrate an understanding and interpretation of the world as a set of related systems [1].

Consequently, the learner develops (a) correct use of Mathematics; (b) number vocabulary, number concept, calculations and application skills; (c) learning to listen, communicate, think, reason logically and apply mathematical knowledge gained; learning to investigate, analyze, represent and interpret information, pose and solve problems; and (e) building awareness of the important role that Mathematics plays in real-life situations, including his/her personal development [1]. The intended CAPS prescribed various topics and the content areas to be covered in each grade with time allocated specifics together with the weighting of the content areas in each phase, outcomes and relevant assessment examples. Mathematics is taught at foundation (grades 1-3), intermediate (grade 4-6), senior (grade 7-9) and further education and training (grades 10-12) phases. Ramatlapana and Makonye [4] assert that although the teachers were free to teach the previous curricular as they saw fit, CAPS was prescriptive and demanded uniformity in implementation across the country. This prescription was enforced because the freedom with the implementation of changed curricular were 
counter-productive since learners' performance continued to be poor in mathematics. This was evidently reflected from national school assessments and also in the Trends in Mathematics and Science Study (TIMMS) [5] together with Southern and Eastern Africa Consortium for monitoring Educational Quality (SACMEQ) [6], Government officials and mathematics subject advisors are able to monitor the present curriculum. This is because the mathematics content to be taught is explicitly delimited, paced, and sequenced with prescribed mathematics textbooks that point to certain examples. However, Ramatlapana and Makonye [4] argue that the said prescription restricts the mathematics teachers' professional autonomy. This curriculum is favored in the country because it is helpful in the teaching of low achieving learners from disadvantaged socio-economic backgrounds using a more structured teacher directed instruction [7]. In addition, systematic efforts to change the practice, attitudes and beliefs of mathematics teachers in the classroom so as to effect the learning outcomes of students and familiarize teachers with the implementation of the curriculum are effected through Mathematics Continuous Professional Development programs. Those programs were geared to address the quality of mathematics education, improvement of quality of mathematics teachers, numeracy and mathematics teaching in lower grade levels.

Reference [8] suggests changes to the way mathematics is perceived. Those changes include: (i) In 1994, mathematics was a compulsory school subject until grade 9, and beyond that it was not compulsory. Those who registered for it at matric level did it on either higher or standard grade until 2007. (ii) In 2001 and 2002, the Outcome-Based Education (OBE) and the Common Task for Assessment (CTA) was introduced to high school learners, but was shortly discontinued due to serious challenges in terms of its implementation. (iii) In 2005 another curriculum change in the form of an "outcomes-based" approach was introduced. This change had a major impact in the learning and teaching in the GET (grades 7-9) due to the fact that it was very vague in terms of what had to be taught in different grades [8]. (iv) Curriculum change over the years has also affected the content to be taught in different grades. Changes involved moving content from one grade to another; removing some content and introducing new content. Recently, Technical Mathematics and Technical Science in technical schools in grade 10 from 2016 has been introduced. This clearly indicates that curriculum change in South Africa is a continuing process. Coupled with the change in curriculum was also the introduction of Mathematical Literacy as an alternative to be done by students who were not competent to do mathematics in the FET phase. This was done to cater for those students who could not do pure mathematics and to retain the compulsory status. This then ensures that all learners are exposed to some form of mathematics by the time they finish school.

\section{The exploration of mathematics education, democracy and development}

The connection in the triad of mathematics education, democracy and development brings critical engagements with the country's developmental features like poverty and inequality. One of the reasons why mathematics was made compulsory was in the fact that in this day and era, it is used by people, institutions and agencies through all types of applications that come to produce and result in a formatting of society. It therefore requires a more sophisticated mathematically literate person to question the applications within a democracy since an increasing amount of some mathematics is found in all areas of life today. The recently introduced new Mathematics and Mathematics Literacy curricula for grades 10-12 in South Africa 
could be a redress to ensure that all South Africans are mathematics literate and numerate. Also the evidence in this line of argument is that access to and competence in mathematics serve very different purposes. The implications of both the presence and absence of mathematics education has real consequences since it is used in a multitude of ways in society like predicting, controlling, interpreting, describing and explaining within a particular cultural, economic and socio-political context. Furthermore, mathematics is expected to integrate a critical, democratic and mathematical competence such that citizenry participates meaningfully in the growing economy. Consequently, South African citizens would then be able to grasp the mathematical basis implicit in the decisions taken for or against them [9].

In essence, the developmental challenge for mathematics education is not confined to particular parts of the world, South Africa is included. Venkat et al. [9] proposed a significant new role in contributing to the acceleration of eradicating poverty, promoting gender equality and universal primary education. The author further suggests that mathematicians and mathematics educators need to work together, from different levels of the education system, in different aspects of research and practice, from different perspectives, and from different parts of the world. This according to [9] would address poverty, injustices, inequity, illiteracy and access to education. In addition, Venkat et al. [9] suggest that in order to create employment and to fight poverty, mathematics education can be used to empower people with knowledge and skills that are necessary to reach the targeted economic growth rates. The author further argues mathematics is required to analyze most of the skills areas of the economic sectors that are being targeted to ensure growth is achieved in the country. A shortage of skilled people who can make things with their hands, those skilled in the technique of an art or craft, engineers, architects, doctors, together with many of those who are involved in various kinds of applications of mathematics in South Africa, has been registered in the country. Therefore, for economic growth, the strengthening of mathematics teaching in schools is important in order to reach development goals and the needs of the impoverished and marginalized communities. The improvement of the basic conditions of peoples' lives, including schooling and the quality of all aspects of mathematics education is crucial to sustaining democracy in South Africa.

In addition to the mathematical knowledge and skills needed in the twenty-first century, mathematics education and performance in the subject determines access to jobs and further or higher education studies in a range of areas, from the natural and physical sciences to economics and technology. Thus, mathematics is on the one hand regarded as a gateway subject, a requirement for admission to learning a large number of these high-status, high-paying professions. On the other hand, it also functions as a gatekeeper, a sorting mechanism used to keep some people who fail to learn and perform at the requisite levels or are failed by the education system [9]. In this way, the teaching and learning of mathematics stratify the society. It is in this notion that mathematics education becomes responsible for the country's economic growth.

\section{The distribution and educational possibilities of mathematics education}

The distribution of mathematics education is made visible and public through international studies of student mathematics performance and national tests and assessments. South Africa's poor performance in Mathematics and Science education quality was highlighted in the first three TIMMS reports-1995, 1999 and 2002. Feza [7] asserts that South Korea and Singapore which are two of the top performing countries in TIMSS had gone through curriculum changes reforms 
driven by political influences and have managed to have their students as the lead performers in TIMSS. However, South Africa's repeated ranking at the very bottom of TIMMS and equally poor outcomes in the annual high-stakes national grade 12 matric examination results, follow with endless speculation about the reasons and causes of South Africa's continued poor mathematics performance. Feza [7] further suggests some factors behind the poor mathematics performance in South Africa as those that connect with curriculum implementation and teacher readiness. The mathematics teachers' classroom practices remain unchanged although the current implemented curriculum prescribes precise content that must be taught to learners at various levels. This can be associated with the observations of the Education minister, Motshekga [10], who noted that "South Africa is significantly under performing in education in general, particularly mathematics teaching and learning. Mathematics teaching is often poor quality, with teachers not able to answer questions in the curriculum they are teaching, one indicator of the challenge. Often national testing is misleading as it does not show the major gap at lower grade levels." In an endeavor to address this saga, the government opted to define the set of values for the teaching and learning of Mathematics in the South African context. It was also acknowledged that in education, the country was doing well in terms of the fact that all learners had access to some mathematics studying, equity, but quality was lacking. Mostly, the underperformance was visible in the public sector schools that form about $80 \%$ of schooling in the country. OECD [11] associated the South Africa's mathematics educational outcomes with the aggravation of the excess supply of unskilled labor and worsening income inequality in the country. This crisis has recently worsened as the department of education has decided to progress learners who did not meet the minimum mathematics requirements for progression to the next grade in the senior phase, grades 7-9. I argue in this chapter that the progression of learners who fail mathematics compromises the country's future quality of human capital and economic growth. I further suggest that this can be redressed by subjecting underqualified mathematics teachers, those who had done standard grade mathematics to an intense compulsory in-service mathematics teacher training process. In this way mathematics teachers would be equipped with both pedagogical knowledge and mathematics content for teaching the subject.

In the past decade, Venkat et al. [9] asserted that the number of students seeking to become senior secondary teachers of mathematics in schools has not kept pace with demand. Teaching is unable to compete with the status, remuneration and prestige of other expanding career options in science and technology, given the small pool of successful candidates in matric mathematics. This is associated with the fact that in South Africa, through the deliberate underdevelopment of apartheid, the mathematics education system has inherited a nature of teachers with diplomas as opposed to degrees, who were underprepared in handling the content of the changed curriculum. This legacy remains intact and must be addressed for any reversal of the past and for substantial improvements in providing learners with adequate and appropriately qualified mathematics teachers. Those teachers will then acquire the kinds the mathematical knowledge and skills promised in the current CAPS curriculum. Parker [12] notes that approximately $20 \%$ of grade $10-12$ mathematics teachers are professionally unqualified and of those that are qualified, still only $21 \%$ have some university level courses. In addition, there is also evidence to the fact that qualified mathematics teachers in the system are either not teaching mathematics or not teaching it at the level at which they are qualified $[12,13]$. Moloi [6], for example, argues that quality mathematics teaching in South Africa will continue to be a phantom unless (i) there is a quality teacher education that refreshes teachers' competencies; (ii) teachers make efforts to understand how their learners think and learn, and recognize the learning experiences of their learners; and (iii) teachers are given the necessary support by the 
authorities. Some of the qualified mathematics teachers either serve in management positions in schools rendering therefore a limited human capital that can assist with effective mathematics teaching. This challenge has exacerbated to a level in which the education minister has lowered the pass requirement for mathematics at grade 12 matric level to $20 \%$ across the country, a political decision that hits back to the country's economy as affected students cannot enroll for scarce skills at tertiary institutions although they have passed. In the most impoverished parts of the schooling system, better distribution of the educational opportunities for many more marginalized learners to effectively improve in mathematics performance, requires a targeted, systemic and systematic long-term mathematics teacher continuous professional development, a stable curriculum policy environment, and, a critical level of resourcing and schooling infrastructure for the mathematics education system to function.

\section{The introduction of mathematical literacy}

The subject mathematical literacy (ML) was introduced at in South African schools in 2006 as a compulsory alternative to mathematics. This was done to ensure that every citizen was allowed some form of mathematical skill which they can use in their personal and work-related life (Subject Guidelines NC (V)) [1]. Although this was a good intention, not all the objectives of the subject were accomplished. First at the time of its introduction, there were no trained qualified teachers to handle the subject. Secondly, it was enrolled at grade 10 level by students who did not perform well in pure mathematics and had a weak pass in their grade 9. Such students also struggled to perform well in languages and other subjects. The objective of ML becoming a high-quality subject, which can stand independently with its own set of objectives, and not to be compared with mathematics, is one of those that were not accomplished. Equally shocking was the announcement that ML had since 2014 also not shown any improvement in students' poor performance up to 2016 [14].

Mathematical literacy (ML) is a context driven subject that is taught and learnt from a contextual framework [4]. According to the subject guidelines for ML, Ref. [1] prescribes that it is a subject that is meant to equip the student to deal effectively with everyday problems. According to the Curriculum and Assessment Policy Statement (CAPS) curriculum documents [1], 'mathematical literacy is defined as follows: The competencies developed through Mathematical Literacy allow individuals to make sense of, participate in and contribute by becoming responsible citizens who base their decisions on sound information to the twenty-first century world- a world characterized by numbers, numerically based arguments and data represented and misrepresented in a number of different ways. Such competencies include the ability to reason, make decisions, solve problems, manage resources, interpret information, schedule events and use and apply technology' [1].

The implications of the above statement is that Mathematical Literacy allows citizens to make informed decisions and choices after carefully considering all information in its contexts by comparing, conjecturing, calculating and problem solving through the use of numbers and by using and applying technology to assist them. It further states that citizens will be allowed to utilize resources, human or otherwise, in a very optimal manner based on their calculations made. Although the above was an expected outcome of the implementation of ML, not much research had been done to verify whether this is what is actually happening in real life for those students who have gone the ML program at schools. But recent studies point to the fact that the percentage failure rate is higher in Mathematical literacy than pure mathematics in grade 12 matric level. In addition, a major concern was when Umalusi (a body that quality assures grade 12 matric results in South Africa) 
announced in 2016 that the "needle for mathematics has not moved", which meant that there was no significant improvement and noticeable difference in the marks for mathematics since 2014. Equally shocking was the announcement that ML had since 2014 also not shown any improvement up to 2016 [14].

\section{The research trends and their effect on mathematics education in South Africa}

In conjunction with the changing landscape of post-apartheid South Africa, research themes explored in mathematics education include assessment; issues of language; aspects of radical pedagogy and progressive classroom practices; ethnomathematics; and teacher education. Nonetheless, it would be of interest to see how all stakeholders understand the connections between curriculum research, reform, policy and practice in mathematics education. Adler et al. [15] report a considerable increase in primary mathematics education over the past decade. This could be a response to South African mathematics education registered challenge wherein learners' performances at all levels, and teachers' specialized mathematical knowledge [2] was significantly low. The Centre for Development and Enterprise (CDE) is one of South Africa's leading development think tanks, focusing on vital national development issues and their relationship to economic growth and democratic consolidation. Spaull [13] who compiled the CDE report assert that that despite some improvement, South Africa is still significantly underperforming in mathematics education. The data they collected points to indicators on school performance and teaching reveal largely unacknowledged poor teaching of mathematics in the great majority of schools. This is despite the fact that mathematics is a key requirement for not only entry into higher education, but also for most modern, knowledge-intensive work. The most recent report from the Head of the Department of Basic Education's National Education Evaluation and Development Unit (NEEDU), argues that poor learner performance in most schools is largely due to the poor subject knowledge of teachers, especially in mathematics. The government official remarks that this is as a result a major problem in with teacher complacency, which is linked to the ways in which many teachers are appointed, often not on merit.

Informed by the research conducted, Spaull [13] developed four points that must be borne in mind in addressing South Africa's numeracy and mathematics schooling challenge, that (i) although the improvement of mathematics teaching and learning in public schools will not happen fast, it must begin urgently; (ii) poor mathematics and numeracy teaching and learning in public schools accelerate private schooling wherein there is enrolment growth in private extra mathematics lessons; (iii) if South Africa is to be realistic about having a knowledge economy and creating more and better jobs, it will require a sustained focus on teacher and teacher-training development, particularly in mathematics teaching, and (iv) in the interim, it is likely that the country will have growing numbers of innumerate young people, and a majority of young South Africans could be unqualified to be hired in many types of high quality work. Spaull's [13] research suggests (i) the address of the inefficiencies in basic education that result in escalating numbers of drop-out students from grade R-12; (ii) the development of early childhood and special needs mathematics education programs; (iii) a systemic account of public further education and training colleges on how they train mathematics teachers, together with (v) low pass rates in higher education institutions which were roughly half the learners at contact education universities who start a bachelor's degree graduating while only 40 per cent of diploma learners graduate. Further research recommended is on whether (i) the selection, appointment and promotion of mathematics teachers is based on their teaching qualities, as opposed say to the teachers' other relationships 
or affiliations to unions; (ii) consideration of whether a system of teacher rewards for learner performance in mathematics can replace a formal teaching qualifications (iii) the allocation of more resources to teaching in school grades with the most serious deficiencies can make the most difference to end results at grade 12 matric level; and (iv) how teacher complacency van be addressed in mathematics education.

\section{Mathematics teacher training and empowerment}

Stinson [16] projects a historical perspective that reveals existence of mathematics as a gatekeeper in the education system structure of the United States. Equally a good performance in mathematics at grade 12 level allows students to enroll and follow careers of high stature in South Africa. Thus it is important that high quality training of mathematics teachers is ensured such that they are able to equip students with high critical thinking and problem-solving skills.

Mathematics teacher training in South Africa was handled by training colleges prior to the re-dressing of the education system under the apartheid era. Those colleges were divided to the various levels in which the teacher was going to teach. For example teachers who did primary teachers' course (PTC) were enrolled to complete their 2-year certificate qualification in primary teachers' colleges. Different colleges enrolled and trained teachers who were prepared to teach in secondary schools and those were awarded a Junior Secondary Teachers' Course (JSTC) certificate after 2 years. In addition there were those few who were trained via a 1 year higher diploma in education (HDE) in universities after the completion of their first degrees. This last group was composed of few students who would join teaching because of other shortcomings or standards that they could not meet in order to advance to higher degrees. This was all because teaching as a profession was and still is an unpopular profession that is not highly recognized in the country.

During the post-apartheid era, many colleges were closed and or changed to be centers for Further Education and Training (FET) colleges or Technical and Vocational Education and Training (TVET) according to Act 98 of 1998. Thus teachers were now trained in universities. The bachelor of education (BEd) course has a duration of 4 years. For a candidate to be able to complete training to be a mathematics teacher, he/ she must have done mathematics up to second year level. Others would enroll for a junior Bachelor of Science (BSc) degree after which they enroll for a 1 year post graduate certificate (PGCE) course in mathematics didactics. Due to the high unemployment rate that is dominant in the country, some currently employed mathematics teachers hold an engineering junior degree but opt for teaching to escape the poverty lines. Consequently, Kaino et al. [17] assert that current mathematics teachers in the field today are a combination of a set of teachers with non-matching school subject knowledge and contrasting models of classroom practices together with proactive, reactive and over-reactive teachers [18]. The authors, Kaino et al. [17], further note that teachers with non-matching school subjects require continuous professional development to address and adjust to the consequences of an environment characterized by enormous infrastructural backlogs, resource limitations, an inadequate supply of quality learning support materials, and the absence of common national standards for learning and assessment.

It is for this reason that in each of the provincial departments in South Africa, members of the Sub-Division of the Professional Development and Research Division are responsible for the implementation of the Continuous Professional Teacher Development Management system in all provinces. Such provision is facilitated through the South African Council of Education (SACE) who liaises with other stakeholders like teacher unions, School Governing Body associations and others to approve service providers in different provinces in South Africa. Also mathematics teachers at various 
levels work with projects initiated by South African universities to be empowered and improve their mathematics pedagogical skills. It is my contribution and proposal in this chapter that mathematics teachers need to undergo compulsory professional training in-service before they are permanently employed. It is during that training that the mathematics content knowledge gap can be closed and that they would be equipped with the competencies of handling the subject even in under resourced trying conditions. This is practiced in other countries like South Korea and Singapore. The students in those countries are taught well and perform very well in mathematics.

\section{Conclusion}

Investigations on the South African mathematics education system have consistently revealed how critical the situation is. Irrespective of the highlighted shortcomings and condition surrounding the teaching and learning of mathematics, echoing the irregularities in the system will not help, but the existing challenges must be addressed. Clearly a political solution in which the quality of successful performance standards in mathematics at grade 12 matric level have been lowered to $20 \%$ is not a solution. That compromise psychologically disadvantages concerned students who would like to pursue careers in which mathematics is required. In this chapter, I argue that teaching is an art and the teaching of mathematics requires continuous professional development that equips that teachers with mathematics content at various levels and how it can be presented in the classroom. The supervision of mathematics teaching practice must be preceded by demonstrated micro-teaching lessons on various topics. All mathematics teachers should have access to mathematics open education resources that are freely available online.

Also, a shift in the mindset of mathematics teachers must be promoted. The department of education can consider bring back the training colleges such that quality mathematics teachers can be trained. The performance in the subject must be detached from politics and be controlled by conceptual knowledge of the subject. In that way students will not be taught for passing mathematics in different levels, but rather understanding that can assist the student to connect and apply learnt and known mathematics concepts to the improvement of their daily lives. A system that empowers and compels mathematics teachers to serve for 2 years before they are permanent, as practiced in Singapore can turn the tables around for South Africa.

\section{Author details}

Zingiswa Jojo

University of South Africa (UNISA), Pretoria, South Africa

*Address all correspondence to: jojozmm@unisa.ac.za

IntechOpen

(C) 2019 The Author(s). Licensee IntechOpen. This chapter is distributed under the terms of the Creative Commons Attribution License (http://creativecommons.org/licenses/ by/3.0), which permits unrestricted use, distribution, and reproduction in any medium, provided the original work is properly cited. (cc) BY 


\section{References}

[1] The Departments of Basic Education and Higher Education and Training. Integrated Strategic Planning Framework for Teacher Education and Development in South Africa, 2011-2025. Pretoria; 2011

[2] Bjorklund AS. Eleven Eastern Cape Teachers' perceptions of the implementation of the curriculum assessment policy statement. Thesis in pedagogy in the field of curriculum reform. Minor Field Study. 2015

[3] Carnoy M, Chisholm L, Chilisa B. The Low Achievement Trap: Comparing Schools in Botswana and South Africa. Pretoria: HSRC Press; 2012

[4] Ramatlapana K, Makonye JP. From too much freedom to too much restriction: The case of teacher Autonomy from National Curriculum Statement (NCS) to Curriculum and Assessment Statement (CAPS). Africa Education Review. 2012;9(suppl 1): S7-S25

[5] Howie S. Mathematics and Science Performance in Grade 8 in South Africa 1998/99. Pretoria: Human Sciences Research Council; 2001

[6] Moloi MQ. Mathematics achievement in Southyn Africa: A comparison of the official curriculum with pupil performance in the SACMEQ11 project. In: Paper presented at the International Invitation Education Policy Research Conference; 2012

[7] Feza N. Good intentions are not actions: Mathematics education of South Africa demands action and pride from the citizenry. Mopani-Kruger National Park, South Africa: ISTE; 21-25 October 2014

[8] Govender VG. Factors contributing to the popularity of mathematics olympiads and competitions in some schools: An interrogation of learners' and teachers' views. In: Proceedings of the 24th Annual National Congress of the Association for Mathematics Education of South Africa; 2012

[9] Venkat H, Adler J, Rollnick M, Setati M, Vhurumuku E. Mathematics and science education research, policy and practice in South Africa: What are the relationships? African Journal of Research in Mathematics Science and Technology Education. 2009;13(special issue):5-27

[10] Motshekga A. Statement on the Release of Annual National Assessments. Results for 2013. Atteridgeville: Mahlahle Primary School; 2013

[11] OECD. Education at a glance. In: Education Indicators. Paris: OECD; 2008

[12] Parker D. Grade 10-12 mathematics curriculum reform in South Africa:

A textual analysis of new national curriculum statements. African Journal of Research in SMT Education. 2006;10(2):59-73

[13] Spaull N. South Africa's Education

Crisis. Johannesburg: Center for Development and Enterprise (CDE); 2013

[14] Umalusi Report on the Annual National Assessment of 2013: Grade 1 to 6 \& 9. Pretoria: Department of Basic Education, Umalusi on their 2013/2014 Annual Reports, with Deputy Minister present, NCOP Education and Recreation; 2014

[15] Adler J, Alshwaikh J, Essack R, Gcsamba L. Mathematics education research in South Africa 2007-2015: Review and reflection. African Journal of Research in Mathematics, Science and Technology Education. 2016. DOI: $10.1080 / 18117295.2016 .1265858$ 
[16] Stinson DW. Mathematics as "gate-keeper" (?): Three theoretical perspectives that aim toward empowering all children with a key to the gate. The Mathematics Educator. 2004;14(1):8-18. Available from: http:// math.coe.uga.edu/tme/Issues/v14n1/ v14n1

[17] Kaino M, Dhlamini JJ, Phoshoko MM, Jojo ZMM, Paulsen R, Ngoepe MG. Trends in mathematics professional development programmes in postapartheid South Africa. International Journal of Educational Sciences. 2015;8(1-ii):153-163

[18] Lindeque B, Gawe N, Vandeyer S. Context analysis. In: Teaching-Learning Dynamics. Edinburg Gate, Harlow, England: Pearson Education South Africa (Pty) Ltd.; 2016 



\title{
An Epistemological Critique of the African University Education System
}

\author{
Ephraim Taurai Gwaravanda
}

\begin{abstract}
This chapter is a theoretical exposition of the African university education system that is characterized by domination of the Eurocentric epistemological paradigm owing to factors such as colonialism, imperialism, and globalization. I argue that such domination contradicts knowledge democracy and it ought to be challenged. Secondly, I argue that African universities should make the African epistemological paradigm central in their education system. Thirdly, I argue that South-South cooperation should be adopted by African universities to challenge Eurocentric domination since a collective effort, rather than individual attempts, is likely to dislodge foreign epistemological domination.
\end{abstract}

Keywords: African university, epistemology, Eurocentric hegemony, African knowledge systems, knowledge democracy

\section{Introduction}

Global debates on the understanding of education systems have demonstrated that the Western conception of knowledge as justified true belief is problematic especially when applied to non-Western categories of knowledge. The domination of the Western conception of knowledge has historically and systematically marginalized, silenced stereotyped, dislocated, and decentered alternative conceptions of knowledge in systems of education. The use of the term "African epistemology" has resulted in debates on whether the adjective "African" is necessary especially in the areas of decolonization, Africanization, and transformation of education. The central claim in this chapter is that Western epistemology which dominates African universities is heavily individualistic, yet knowledge is understood as communalistic in the African setting. This scenario requires rethinking so that African universities reflect an African epistemology in their production of knowledge. This is important because knowledge production is central in the university system.

I intend to answer the question of the relevance of African epistemology in African universities by justifying its uniqueness through showing the elements of relationality, dependence, and interdependence. While a lot of literature has been written to justify the use of African epistemology in African universities, this chapter shows the significance of an African relational epistemology within African universities. The research gap I wish to fill is one which provides the relevance of an African relational epistemology to the African university system. I intend to go beyond the 
debates on Africanization, decolonization, and transformation of the African university by concentrating on epistemological matters that affect African universities.

The work is divided into four sections. The first section examines the notion of "African university" in the context of epistemology to argue that the notion is logically incoherent. The second section is a critique of Western epistemology that shows that knowledge cannot be transcultural when it is practiced within cultural settings. The third section explores the relevance of African relational epistemology within the African university. The fourth section shows the importance of dialog and links with other epistemic perspectives in the global south with the aim of dislodging Western epistemological hegemony within universities of the south.

\section{The African university in the epistemological context}

Before focusing on the meaning of the term "African university," it is important to define the concept of a university. Ryle gives an analogy of a university visitor who is shown key physical structures of a university such as administration blocks, lecture rooms, and libraries. The visitor, having seen key parts of the university, still insists on asking where the university is. The visitor fails to connect the university to its parts so as to realize that real university is a system of how the parts are organized into a functional organic whole. While the visitor assumes seeing the university in the literal sense, the seeing that allows one to understand is in the sense of grasping the connectedness of parts. Beyond Ryle's analogy, I argue that a university is beyond a mere organization of physical structures but it also involves the thinking system that forms the intellectual foundation of the university. This intellectual foundation is the epistemological paradigm. The question I examine in this chapter is whether a foreign epistemological paradigm can be authentic or genuine enough to solve the problems of the host continent [1].

From Ryle's analogy, two issues can be drawn. Firstly, a university is a system that is coordinated for an intellectual purpose as evidenced by research and learning. While this systematic arrangement involves physical buildings, these buildings are simply parts of a whole, and one will commit the fallacy of division if one identifies the university with its parts. The second aspect raised by Ryle, which is critical for this research, is that the coordination of the parts of a university must be understood. The understanding involves going deeper that appearance to give a detailed analysis of the essential components of what makes a university. This level brings up the question of epistemic spaces, the intellectual freedom, and the purpose of a university to the community in which it is found. Although Ryle himself may not have raised these issues, they arise when attempting to fully understand what a university entails. The key function of the university is to search for truth. This function is facilitated by a love of learning and respect for knowledge. The love for learning gives a sense of wonder that propels the desire to seek new knowledge. The respect for knowledge involves examination of key theories, concepts, and categories without any bias [1]. The question of searching for truth is important for this research since the key assumption is that some knowledge systems have been sidelined by an epistemological paradigm whose understanding of truth is onesided, narrow, and undemocratic. In addition, a university should allow "the will to search and seek without limitation, to allow reason to develop unrestrictedly, to have an open mind, to leave nothing unquestioned, to maintain truth unconditionally" [1]. Ogwuanyi's view shows that university should be reflective and even be self-reflective in the sense of questioning and evaluating its own steps and practices. Having looked at the broad understanding of a university, it is now important to explore the question of African university. 
The African university education system is currently dominated by Western epistemology where the analytic model of knowledge is being used. The model relies on the definition of knowledge as justified true belief. This definition of knowledge is not only foreign to the African university but it also has implications that are inconsistent with the African ways of knowing. The Western definition of knowledge excludes social epistemology that is fundamental in the African knowledge paradigm. African knowledge systems validate knowledge through the community. The African university education find itself in the paradox of mimicry and are currently dualized along Eurocentric thought (which is the dominant one) and weak Africanized curricula which blends both Eurocentric thinking and African indigenous knowledge system. However, it has to be pointed out that African knowledge systems contribute an insignificant part in the weak Africanized curriculum.

The African university education is currently dominated by Eurocentric epistemology. Eurocentric epistemology creates contradictions, uncertainties, and dilemmas. Eurocentric epistemology assumes a "universalistic, neutral, objective point of view" [2]. Following such epistemological underpinnings, African universities have used universality, objectivity, and neutrality to define and influence content of the curriculum without the problematization of these concepts. "Universality" hides the subject and claims knowledge applicability "always and everywhere" to borrow the Kantian phrase. Critics of Eurocentric thinking have argued that "universality" is a myth [2-4]. The aspect of location should therefore be included in knowledge claims without assuming Kantian universality. "What I am claiming is that all knowledges are epistemically located in the dominant or the subaltern side of the power relations and that this is related to the geo- and body-politics of knowledge" [2]. Neutrality in the sense of observer independence is when the "ego-politics of knowledge" of Western philosophy has always privileged the myth of a non-situated "ego." Ethnic/racial/gender/sexual epistemic location and the subject that speaks are always decoupled. Objectivity entails that "in Western philosophy and sciences the subject that speaks is always hidden, concealed, erased from the analysis" [2]. By delinking ethnic/racial/gender/sexual epistemic location from the subject that speaks, Western philosophy of science defends universal categories that are seen as applicable always and everywhere. These universals are also understood to be impersonal and beyond emotions. Against Western universalism, I argue that if concepts, universal as they may be thought to be, are formulated within a cultural setting, then the concepts cannot be transcultural [2]. Knowledge is always from a particular location [4-6], and there is no need to marginalize other locations. "Nobody escapes the class, sexual, gender, spiritual, linguistic, geographical, and racial hierarchies of the 'modern/ colonial capitalist/patriarchal world-system"” [2]. These claims are reinforced by the view that our "knowledges are always situated" [7].

The Cartesian "cogito, ergo sum" ("I think, therefore I am") is the foundation of modern Western sciences. It is the basis of the idea of "objectivity" as seen in natural sciences. While Western science borrows heavily from the Cartesian approach, scientists and academics from African universities have endorsed this without criticism. By producing a dualism between mind and body and between mind and nature, Descartes was able to claim non-situated, universal view of knowledge. The universal view of knowledge allows Western epistemology to disregard all other forms of knowledge. The neutral view is called the "point zero" [8] perspective of Eurocentric philosophies. By “point zero," Castro-Gomez refers to a form of neutrality, and it has been argued that in research and teaching, including African universities, neutrality is a virtue. The point zero is beyond both subjectivity and relativity, and it is understood as beyond a particular perspective or locality. 
Critics of universalism see the point zero approach as beyond human capacities and an approach applicable to some kind of deity [2]. The ideals of objectivity and universality are not immune from criticism, and the next section examines the flaws of these ideals.

\section{Critique of Western epistemology}

Objectivity may be defined as neutrality or observer independence. This entails that epistemological claims must be free from subjective or cultural bias. Truth claims should be free from observer bias and not depend on the fact that a particular person is conducting investigation. Every person, including the epistemologist, looks at the world from a particular perspective, shaped by personal and cultural facts [9]. Critics of objectivity argue that hidden cultural assumptions distort our investigation of truth. Hidden cultural assumptions that distort the conclusions of science can be made visible by beginning from a marginal perspective. Instead of occupying a "view from nowhere," thought begins from somewhere. Once that is understood, the task is which somewhere should we examine the world. Philosophy should challenge its own picture of itself by criticizing both the project and assumed goal of Western philosophical reflection [10]. Philosophical investigations are subject to historical and cultural particularities. Philosophy is written and explored within cultural contexts. The timeless nature of reality, justice, and truth is ought to be challenged. The assumption that reason is a transcendent, noncultural standard ought to be rejected. Reason is actually justified not as timeless truth but as a local ideal. Reason is used by philosophy to show particular versions of truth. It is easy to write about the "other" or voice from the margin. What appears about embracing the other is largely rhetoric. A standpoint theorist sees possibility, promise, and hope as emanating from the margins [11]. A conceptual scheme is a way of seeing the world. Incommensurable conceptual schemes [12] are schemes that are so fundamentally different from each other that they cannot be compared or ranked or united into a single scheme. Different cultural traditions provide incompatible ways of separating valid truth claims from invalid ones. These ways are internal to cultures, and there is no transcultural way of sorting out the contradictory truth claims. The West should recognize the failures of its own traditions and open up to new traditions especially the ones that promise to overcome our failures by providing clear and careful standards of justification.

Eurocentric thinking is internally limited by its own narrowness and perspective. "Eurocentrism is unable to deal with the assumptions and complexities of colonialism and it is unable to reject the use of Eurocentric theory or its categories" [13]. So eurocentrism is a self-limiting approach which African universities have no justification in following. It is a form of provincialism that has to be evaluated using the lenses of pluriversality.

Eurocentric epistemology is a kind of provincialism whose narrowness contradicts the spirit of genuine knowledge. If knowledge should be open-ended and tentative, then why should gatekeeping be done using the myths of universality, objectivity, and neutrality? The idea of the universal is that of a universal rich with all that is particular, rich with all particulars, the deepening and coexistence of all particulars [14]. Pluriversality respects both multiplicity and diversity. It picks the best elements from each culture and tradition. This means that it is the sum total of the best elements from each culture and it takes the dimension of multiple thinking without disregard on any of the cultures. This kind of thinking brings in the idea of pluri-cultural perspectives that engage in honest dialog for the enrichment of knowledge in particular and humanity in general [4]. Le Grange writes, "for too 
long what has been taught and learned in African universities has been dominated by Western science disciplines and more importantly by a representationalist perspective of science or knowledge" [15]. What is taken as genuine knowledge in African universities is a perspective that requires revisiting and reconceptualization. In Le Grange's view, Western science "is not only local but located" or situated. The locality is hidden in abstract universalism. Abstract universalism is used to dismiss other knowledge systems as non-knowledge. The narrowness and fallacies of Western science should allow indigenous knowledge to stamp authenticity in the African university.

The use of Eurocentric epistemology in African universities disrespects the epistemic concerns of students. Arguably, "many spaces within the university do not recognize the knowledge and cultural capital that first-generation students bring with them to the university as valid forms of knowledge and as valid forms of cultural capital" [16]. This gives a mismatch between the learners' epistemological background and university learning. As a result, graduates from a contradictory learning process fail to attain relevance in their own communities because there is unequal participation in the learning process. "Higher education must be made relevant to the material, historical and social realities of the communities in which universities operate" [17]. Such unequal participation is called "hermeneutical injustice" [18]. In instances of hermeneutical injustice, the power imbalance is such that certain people's positions, and the knowledge they bring from those positions, suffer from a deficit of credibility. For instance, if a student of law brings into the learning process the indigenous court system, that knowledge is likely to be dismissed as "unsystematic and unscientific." Experiences of learners are therefore dismissed when the Eurocentric way of thinking is given domination in African universities. Although hermeneutical injustice was academically defined almost a decade ago, this form of injustice is as old as racism and colonialism. "In South African higher education, this is a hermeneutical injustice with its roots in a colonial past, where other knowledge systems and ways of being were systematically disregarded and perceived negatively" [16]. Education should be liberating instead of enslaving. This means that all processes linked to education such as research, teaching, and learning must free the mind. Freeing the mind entails thinking in diverse positions that involve criticism and evaluation without any blinkers, whether imposed on acquired [19].

Three issues can be drawn from the observation that education ought to be mentally liberative. Firstly, it is a contradiction in terms to talk of education that fails to liberate the mind. Secondly, education should liberate rather than enslave the mind. Colonial epistemology fails to achieve mental liberation in the African university, and it therefore fails to promote intellectual independence and growth. Thirdly, the skills from education are the practical aspects that are relevant for society. If education lacks the practical dimension, then it fails to serve its key purpose.

Universities should be critical about the curriculum by an examination of its theoretical and practical aspects. Theory must feed the practical, and the practical must allow further examination of theory. In other words, ideas must be tested in terms of usefulness to the community. As a result, a curriculum that relates to the community is more appropriate than a borrowed curriculum that tends to be inconsistent with community knowledge systems and experience [20]. To cross the boundaries of one's culture without realizing that the other person may have a radically different approach to reality today is no longer admissible [21]. A university should therefore use the standards of openness and dialog to assess knowledge claims without dismissing them on the basis of prejudice. If still consciously done, disrespect of knowledge from other cultures would be "philosophically naive, politically outrageous and religiously sinful” [21]. The philosophical naivety 
observed is a result of lack of facts, while there is rashness predicated on prejudice. Given the context of colonialism, meaning has to undergo contestation, negotiation, and dialog. In the politics of knowledge, it is irresponsible to dismiss knowledge claims without their contribution taking into account. This thinking opens up for the content of African epistemology as shown in the next section.

\section{African relational epistemology}

In what sense is epistemology both African and relational? African relational epistemology, in this chapter, refers to a theory of knowledge that is both communalistic and informed by African culture. The combination of being communal and a basis on African culture is important because being communal in itself does not qualify knowledge as African since there is Western communitarian thought on the one hand and the existence of multiple non-African but global southern perspectives as found in Latin America and Asia on the other. African culture, in the context of epistemology, supplies the categories and concepts used to validate knowledge claims. African epistemology stands in a special relation to ontology because it starts by recognizing the being of the other. In the context of epistemology, the other is seen as a subject, capable of rational thought and capable of producing knowledge. The other is also important in the validation and evaluation of knowledge claims. African epistemology is relational in the sense that it is both dependent and interdependent. Dependency signifies the reliance on other people for the acquisition of knowledge. Interdependence is a mutual exercise that facilitates the exchange of knowledge between two or more people within the community.

African epistemology demands one to answer the question "what is African about epistemology?” African epistemology refers to a critical analysis of sources, nature, extent, and justification of knowledge using the African conceptual scheme. In the African sense, knowledge is not abstract, but it is related to the world. Knowledge is related to space and time in the sense that it is shaped by these categories. Beyond worldly connections, African epistemology rises above analytic atomistic epistemology through its stress on otherness. Knowledge is acquired through others, and it is validated through others. It recognizes and respects different perspectives. The African knowledge system recognizes the role of the community in the acquisition and preservation of knowledge. The cultural conceptual scheme becomes very important in the sense that it provides a platform for the description, analysis, validation, and evaluation of knowledge. The hierarchy of knowledge starts with the community at the top, followed by groups, and lastly the individual.

According to the Sotho proverb Motho ke motho ka botho, one's humanity is seen through others. In the context of knowledge, the proverb entails that knowledge is passed as such through others. The test of the community distinguishes between propositional knowledge and opinion. Without the community of other human beings, the criterion of knowledge cannot be established. In the context of knowledge, the proverb boils down to the fact that knowledge is acquired, validated, and evaluated through others. In this context, the transition is from the Cartesian "I" to the African "We." A quick objection that is often leveled against communalistic knowledge is that this view of knowledge eclipses the individual within the community. However, communalistic thought does not necessarily eclipse the individual for two reasons. First, thinking is done by the individual, and when thoughts are judged as significant by others, they qualify as knowledge, and secondly, individual points of view are acknowledged in the assessment of knowledge. The proverb 
calls for respectful and polite attitude toward other human beings. To care for one another therefore implies caring for knowledge concerns as well. Without epistemic care, the interdependence between human beings and knowledge would be undermined [22]. The recognition of others in knowledge production becomes important. There is dialog with other epistemic communities in the global south as shown in the section that follows.

\section{South-south cooperation in epistemological issues}

There is no need for African universities to continue to be replicas of Oxford and Cambridge. Knowledge that is generated from African universities should be linked to African experiences so that it is able to solve African problems. Syllabi that are designed to meet the needs of colonialism should not find its way in the postcolonial era [23]. The situation calls for an epistemological transformation of universities. Transformation of the world's epistemological diversity into an empowering and emancipatory mechanism against hegemonic globalization speaks to another kind of bottom-up cosmopolitanism vested in the dialog of humankind, applauding cordiality, solidarity, and living in contradiction of rationality of profit-oriented avarice and egoism [24]. The recognition of epistemic diversity is important for universities in the global south because it helps in dislodging the domination of the north. On the contemporary global arena, the upsurge of knowledge and information is admitted to be one of the key forces of change relative to higher education in Africa, yet modern science, as epistemologies from the north, lack the "capacity to capture the inexhaustible diversity of the world" [24], rendering it a perpetuation of a Western knowledge hegemony and the annihilation of African thinking even in the inquiries about Africa affairs [25]. The situation calls for a reinvention of social emancipation that transcends the critical theory produced in the north and the social and political praxis to which it has subscribed by "opening" of the canon of knowledge, to the ongoing debates and initiatives on diversity and recognition [24]. The opening up of the canon of knowledge facilitates a horizontal progression of knowledge in a manner that accommodates other forms of knowledge through dialog and respect for other epistemic perspectives. Hence there is a need for critical discourses on epistemologies in universities in Africa as part of the south that challenges the "hegemony, universality and violence" [26] ushered in by Eurocentric philosophies just as we might never know where the cures for tomorrow will come from or the new construal of our planet's ecology as whole systems rather than reductionist parts or new ways to conceive of reconciliation or to define the human [27].

The call for a struggle of "alternative" knowledges which need to vigorously challenge the conception of other knowledges as "merely" local or indigenous is an acknowledgment that they are the products of socially systematized practices consisting of the deployment of diverse types of material and intellectual resources attached to specific situations and contexts [24]. The subjection of epistemologies in universities to critique and change over the last three or so decades demanding a criteria of what counts as knowledge and its validation has become, for some, the last crisis of epistemology that occurs through a twin problem of naturalization and historicization. Naturalization of epistemology entails reducing knowledge to the demands of natural sciences such as physics and chemistry where observation and experimentation are key. This is reductionism since it strips knowledge of its normative dimensions. Historicization of knowledge means making the history of knowledge a priority, yet genuine knowledge should address both the present and the future in terms of knowledge validation [28]. The naturalization of knowledge takes the direction of natural sciences where epistemology is reduced to observation 
sciences so that it departs from its normative concerns. Historicization of knowledge reduces epistemology to the history of ideas, and this is also problematic in the sense that the present and the future are left out.

From a radical design, an epistemology must be rooted in the experiences of the global south by critically thinking of contemporary epistemology as a normative project evocative of modern science which can be characterized as epistemological pragmatism. This will not only rescue epistemology from a confinement to, and centeredness on, scientific knowledge alone but to inclusively embrace all forms of knowledge. Santos' case is rooted in the discourse of "decolonising Western universalisms via decolonial pluriversalism" [2] in which the "universal" within the Western philosophical tradition is challenged by proposing an entry of another, more decolonial way of thinking universality [2]. There is no liberation without rationality; but there is no critical rationality without accepting the interpellation of the excluded, or this would inadvertently be only the rationality of domination. Santos makes a case for epistemological and theoretical tasks that can create new possibilities of progressive social transformation aimed at putting an end to the monumental Eurocentric theoretical justification of the unequal relations between the global north and the global south [24]. The proposal for an epistemology of the south is therefore a direct challenge to the neoliberal project which manifests in three major trends in higher education, namely, privatization, commercialization, and corporatization of knowledge as reflected by the unrelenting growth of capitalist and corporate influence $[29,30]$ especially in the university. "In the neoliberal model higher education is ideally integrated into the system of production and accumulation in which knowledge is reduced to its economic functions and contributes to the realization of individual economic utilities" [31].

An epistemology of the south would fittingly be a horizontal rather than vertical array of knowledge forms and sources of hierarchy in which African universities that do not feature on the top 500 of world rankings are rendered poor quality, second-rate, or failures as this is a clear reflection of global inequalities, with the burden of such characterizations weighing in disproportionately on universities in the global south. Besides, setting a "gold standard" [24], by placing knowledge systems on a ranking scale only to selectively discriminate those originating from disadvantaged communities especially in African universities, is to undermine the sources that engender them and a confirmed way of legitimating knowledge hierarchies. One way for African universities to attempt to improve their knowledge status on a global scale is to focus on granting the humanities and social sciences their rightful place in order to confront Africa's development challenges head-on. We argue that to be drawn to the empirical science-oriented platform for which African universities have no resources and general inclination needed to support research in this field is to play the zero-sum game.

I challenge African university leaders to valorize Africanity, and the fruit of their creative imagination (the knowledges they produce) should adopt different forms and manifest themselves differently according to context and necessity [32]. By arguing for an epistemology of the south, I observe Santos' case as a "decolonial epistemic perspective” that will assist with “... unveiling epistemic silences, conspiracies, and epistemic violence hidden within Euro-American epistemology and to affirm the epistemic rights of the African people that enable them to transcend global imperial designs" [33].

\section{Conclusion}

In this chapter, I have argued that the very idea of "African university" is logically incoherent because of excessive reliance on foreign epistemology that negates 
the idea of being African. The core of any university is the advancement of knowledge. Advancement of knowledge is based on a clear epistemological paradigm. The use of Eurocentric models of knowledge in the African university defeats the very idea of "African university." The African university has a history of colonialism that continues to threaten its very existence as evidenced by the domination of colonial epistemology. Eurocentric epistemology has used the ideals of universality, objectivity, and neutrality to hide the locality and situatedness of knowledge. On the basis of these "characteristics" of knowledge, Eurocentric epistemology has set standards of knowledge that African universities have followed for decades without sufficient criticism and evaluation. The use of colonial epistemologies in African universities has no rational justification that is immune to objections, but it is based on a history of fallacious reasoning that Eurocentric epistemology defended as "arguments." The use of colonial epistemologies in African universities disrespects both the students and the communities in which these universities are found. Epistemology from the south is used to dislodge the Eurocentric narrowness in order to pave way for alternative thinking and pluriversality within the African university. African universities should therefore cooperate with other universities within the global south so as to dislodge the tendency by Western epistemology to dominate African universities in the context of epistemology. The relational African epistemology can be used to open up dialog and respect for other epistemological perspectives.

\section{Author details}

Ephraim Taurai Gwaravanda

Department of Philosophy and Religious Studies, Great Zimbabwe University, Masvingo, Zimbabwe

*Address all correspondence to: etgwaravanda@gmail.com

IntechOpen

(C) 2019 The Author(s). Licensee IntechOpen. This chapter is distributed under the terms of the Creative Commons Attribution License (http://creativecommons.org/licenses/ by/3.0), which permits unrestricted use, distribution, and reproduction in any medium, provided the original work is properly cited. (cc) BY 


\section{References}

[1] Ugwuanyi L. The university and the African crisis of morality: Lessons from Nigeria. In: Kenny J, editor. The Idea of an African University: Lessons from Nigeria. Washington, DC: The Council of Research and Values in Philosophy; 2007. pp. 99-111

[2] Grosfoguel R. Decolonising postcolonial studies and paradigms of political-economy: Decolonial thinking and global coloniality. Transmodernity. 2011;1(1):1-36

[3] Alcoff L. New Continental Review. 2007;7(3):79-103

[4] Dussel E. Transmodernity. 2012;3(1):56-60

[5] Moraga C, Anzaldua GE. This Bridge Called my Back: Writing by Radical Women of Labour. New York: Kitchen Table; 1983

[6] Collins P. Black Feminist Thought, Knowledge, Consciousness and the Politics of Empowerment. New York: Routledge; 1990

[7] Haraway D. Situated Knowledge, the Science Question in Feminism and the Privilege of Partial Perspectives. Cambridge: Cambridge University Press; 1998

[8] Castro-Gomez S. The missing chapter of empire. Cultural Studies. 2007;21:428-448

[9] Harding S. Strong objectivity: A response to the new objectivity question. Synthese. 2001;104:331-335

[10] Frazer N, Nicholson L. Social criticism without philosophy: An encounter between feminism and postmodernism. In: Feminism/ Postmodernism. London: Routledge; 1989. p. 1989
[11] Hooks B. Yearning: Race, Gender and Cultural Politics. Cambridge: Cambridge University Press; 1990

[12] MacIntyre A. Relativism, Power and Philosophy. Stanford: Stanford University Press; 1985

[13] Alfraisal H. Border reading, epistemic reading and worlding of postcolonialisms. Transmodernity. 2017;3(1):41-46

[14] Cesaire A. Discourse on Colonialism. New York: Monthly Review Press; 2000

[15] Le Grange L. Integrating western and indigenous knowledge systems: The basis for effective science education in South Africa? International Review of Education. 2007;53(5-6):577-591

[16] Morreira S. Steps towards decolonial higher education in South Africa? Epistemic disobedience in the humanities. Journal of Asian and African Studies. 2015:1-15. DOI: 10.1177/0021909615577499

[17] Letseka M. Educating for Ubuntu/ Botho: Lessons from indigenous education. Open Journal of Philosophy. 2013;3(2):337-344

[18] Fricker M. Epistemic Injustice: Power and Ethics of Knowing. Cambridge: Cambridge University; 2007

[19] Nyerere J. Ujamaa: The Basis of African Socialism. New York: Newark; 1971

[20] Mgqwashu E. Universities cannot decolonise the curriculum without defining it first. The Conversation. 2016. Available from: http://theconversation. com/universities-cant-decolonisethe-curriculum-without-defining-itfirst-63948 
[21] Pannikar R. Myth, Faith and Hermeneutics. New York: Paulist Press; 1997

[22] Ramose MB. African Philosophy through Ubuntu. Harare: Mond Books; 2005

[23] Mbembe A. Decolonising the university: New directions. Arts \& Humanities in Higher Education. 2016;15(1):29-45

[24] Santos S. Public sphere and epistemologies of the south. African Development. 2014;37:43-67

[25] Zeleza P. African studies and universities since independence: The challenges of epistemic and institutional decolonisation. Transition. 2009;101:110-135

[26] Walsh C. “Other” knowledges, "other" critiques: Reflections on the politics and practices of philosophy and decoloniality in the "other" America. Transmodernity: Journal of Peripheral Cultural Production of the LusoHispanic World. 2012;1(3):11-27

[27] Augusto G. Transforming knowledge, changing knowledge relations and epistemic openness in the University in Africa. Social Dynamics. 2007;33:199-205

[28] Nunes JA. Rescuing epistemology. Annual Review. 2009;1(1):1-27

[29] Apple MW. Between neoliberalism and neoconservatism: Education and conservatism in global age. In: Torres NC, editor. Globalisation and Education: Critical Perspectives. London:

Routledge; 2000

[30] Rhoades RA. Globalisation and resistance in the United States and Mexico: The global Potemkim Village. 2. Higher Education. 2007;5:223-250
[31] Morrow W. Bounds of Democracy: Epistemological Access in Higher Education. Cape Town: HSRC Press; 2009

[32] Nyamnjoh F. Incompleteness: Frontier Africans and the currency of conviviality. Journal of Asian and African Studies. 2015;1:1-18

[33] Castells M. The university system: Engine of development in the new world economy. In: Vespoor J, Salmi A, editors. Revitalising Higher Education. Oxford: Pergamon; 1994 



\title{
Pedagogist as Social Professional: Sozialpädagogik and Professional Pedagogy
}

\author{
Franco Blezza
}

\begin{abstract}
The profound changes that have occurred over the last few decades to the social, cultural and relational reality have added a new emphasis on pedagogy even though the emerging need for the profession of "pedagogist," a new intellectual and social profession in common consideration, but which boasts over 2500 years of history and tradition as its reference science. This profession is at the top of pedagogical and education professions. Its conceptual and operational framework, its methodologies and procedures, its technical vocabulary and everything constituting an advanced professional knowledge were born and developed in the ancient times, beginning with its origins in classical Greece. The recent re-foundations can be found in the Sozialpädagogik, in the same Mittleuropean cultural environment where other social professions of recent birth have their ground. Re-founders of this science and profession were Mager, Diesterweg, Natorp and Durkheim Pedagogist. In this paper, we summarized the essential features of this profession, its methodology, its principles, its practical procedures, with special attention to the problems of couple and family, and those belonging to its initial education and its recognition by law which in Italy have been solved only at the end of the year 2017. The branch of General Pedagogy that includes this subject is called Professional Pedagogy.
\end{abstract}

Keywords: pedagogist, social professions, Sozialpädagogik, Professional Pedagogy, methodology

\section{Introduction: a historical contextualization}

Education has faced in the second half of the twentieth century a heavy crisis, which is not finished yet. It is the correspondent crisis society and culture have met in the same period. It was a real epochal transition, from an Evo that lasted less than $2 \mathrm{~s}$ to one that, perhaps, was not yet started.

This crisis involves major social issues such as family and, conceptually before it, the couple and genres. We may adopt in this regard the inclusive concept of 'system' that was introduced in Italy since the 1968 dispute [1] to indicate the whole of sociocultural phenomenon. 'The system' had a profound crisis and owing to it, we understood how and to what extent the system was relying on a peculiar way of raising a family, of living partnership, on a particular construction of genders (i.e., polarized to their extreme extent, functional to the entire system, besides being the very root of it). 
The basic features of this crisis were represented, quite obviously, by the dizzying acceleration of the evolutionary rhythms, by the evident extension of the explicit lifelong education, by the multiplication of access to and dissemination of information, by the generalization of mobility, until the current globalization took place.

In times, chronologically not too far away, although culturally remote, one could at least suggest an education consisting of the replication of some set of patterns. In order that it might actually work, an explicit kind of family education limited to a relatively short period of human life, about a dozen years, and an evolutionary rhythm not too high was necessary. In other words, what we will call 'a quasi-static hypothesis' with a transfer from thermodynamics would have shown its value: that is to say, becoming a process that could be strictly treated as if 'the system' were in every moment of its evolution in a static equilibrium. For these reasons, evolution need not happen according to frantic rhythms, as it would have happened sooner or later, but effectively along those centuries. In addition, the gaps were not to be too long, in compliance with an explicit education that began in childhood and ended, as it was claimed, in adolescence.

\section{A social revolution: new paradigms of couple and family required}

The evolution that occurred includes a profound shift of paradigm with a Kuhnian meaning [2]. We are facing a 'scientific revolution,' which was born more or less around the 1960s or shortly before, and whose problematic content is a big part of our dealing today, and for the next decades. The educational problems posed are direct and mainly dwell on a specific professional sector.

We are problematically leaving a historical age that lasted about two centuries, or less, which properly came after the one that was historiography called 'Modern Age'. The term 'Postmodern' introduced by Jean-François Lyotard [3] was impressive, and effective, to appoint the end of the previous age. The term "post" resulted totally inappropriate and misleading when applied to the history and the humanities. It could have a partial success as well as ephemeral in the domains for which it was coined, that is, in literature and architecture, but had no plausibility in the human sciences and in pedagogy in particular.

The Postmodern Age, put properly next to the 'Modern' one, so-called by history and culture (sixteenth-seventeenth-eighteenth century, about), had its roots in the Enlightenment, the Industrial Revolution and the bourgeois revolutions of the late eighteenth century: in a definite set of ideas and orientations, economic and social upheavals, and spread in the West during the following century. In this specific regard, Der Wiener Kongress formed an unrealistic restoration of political regimes specifically 'modern,' that is to say absolute, which no longer had any cultural, economic and social coherence.

The nineteenth-twentieth century society had as its primary cell a peculiar type of family called by Durkheim "famille conjugale" $[4,5]$ and by Le Play "famille nucleaire" [6]. Its acceptance, with all the heavy sacrifices which involved especially the woman, went hand in hand with the claim that it was the kind of family that 'existed since the ancient times' (or 'natural'), 'traditional' or 'the result of millennia of civilization,' apparently powerful and mutually contradictory and that therefore could only have had a rhetorical function of persuasion and compliance. In fact, it was an absolutely dated and contextualized phenomenon, with its specificity: this paradigm of family completely peculiar and absolutely original has taken the place of the two pre-existing paradigms that remained in the West for many centuries: that is, the noble and patriarchal paradigm. 


\section{The XIX-XX paradigm of education}

The paradigm of nuclear family postulated (and required) a particular type of couple, the so-called overlapping couple, built through polarization of the genders pushed to the extreme, enhanced by a target education in line with its goals.

The dominant educational paradigm in the short Evo XIX-XX was transmissive and consisted of the replication from one generation to another of strict and fixed idealized models, that the teacher had first received and made his own, in such an integral way to feel unconditionally committed to replicate them as closely and impersonally as possible with her/his pupils. Moreover, she/he was considered uncritically entitled to use any tool she/he considered fit for the purpose.

The current information and mobility would be enough to explain the practical impossibility of a transmissive education, especially if focused on fixed models, and this is because these would have lost soon every plausibility and would have proved outdated, overcome by some others as time went by, at least before the end of a dozen years or slightly more. In addition, the longest lifespan of the 'explicit' education in a reality characterized by an increasingly frantic and quick evolutionary rhythm would make obsolete any model or fixed principle, despite its primal validity and soundness, to be checked by information and interpersonal mobility like in our days with no ancestors in human history.

\section{The new social need of the professional at the top of the pedagogical culture}

This particular crisis today is clearly a problematic situation for pedagogy: we refer to a pedagogy that, properly and by its very nature, cannot have any form of detachment, just like, for example, the separation of the historian or what has been attributed to clinical physicians for a long time.

In cases like these, it is manifested more clearly than elsewhere in the application framework that is its true essence, not reducible to merely speculative, philosophical or 'theoretical' thought, but inseparable from taking charge and care of whosoever is going to be educated, in any interpersonal relationship and as a social requirement, and from the organic relationship with the experience of the object of its study and intervention.

This, among other things, is more consistent with the etymology of a term [7] that is present and common in Romance languages, as well as in German and Slavic languages and also in Hungarian, Finnish, Basque or Albanian, while it is still facing difficulties in English. We should not forget that the same term has appeared in the West in 1495, as a mold from Latin [8].

This means that pedagogy is characterized more clearly today than it was in the past, as a domain of study that can be called upon to express its own profession: an upper intellectual profession, working in the social and in all of its instances, whose most proper name is "Pedagogist" (Pädagoge, paedagogist...not to be confused with the educator, l'éducateur or die Erziehrer).

Strictly speaking, the profession of the pedagogist has emerged (or better, reemerged) as a social profession only in the twentieth century. This can be compared to the professions of the psychologist, sociologist, psychotherapist, and in some respect to other intellectual occupations such as the accountant or the social worker.

For all these professions, and others, a wide methodological framework is to be found in the previous century, mostly in Mitteleuropa, in the central European world German-speaking, or in its immediate vicinities. For example, a psychologist would refer to Wundt, Weber, Fechner, Helmholtz, Mach; a sociologist to Auguste 
Comte as the first thinker and then to the Alsatian-Lorraine Durkheim for vast amounts of knowledge and content; and a psychotherapist first to Sigmund Freud, and so forth.

The profession of the pedagogist too finds its foundation in the same world, to be precise, in the establishment of die Sozialpädagogik and in its first steps. We would then refer to Mager, Diesterweg, Natorp, and also the social sensitivity of some pedagogists like Pestalozzi, of course as a generalist or Durkheim himself, considering his character not less pedagogical than sociological, being one of the fathers of the Scientific Sociology. It should be kept in due consideration the fact that he had become a full professor at the Sorbonne in 1906 for the Chair of Pedagogy; it was in 1913 that the name of the course would become Pedagogy and Sociology, and at least in our context, his pedagogical works are not to be considered minor works [9].

\section{Conceptual and operative pedagogist tools from ancient times until the present time}

This reference to the last centuries does not diminish the history of pedagogy, which traces its origins back to Western civilization and that must be considered a resource, as Dewey taught us since he traced it back to the Sophists "the first body of professional educators in Europe" [10], partly because the essential tools both of the reference knowledge and the professional practice are to be found precisely in those classical roots.

We could begin with the classical Greek culture. We will start, therefore,

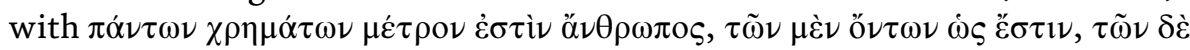

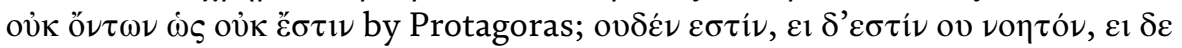

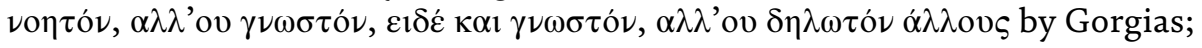

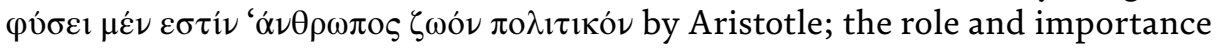

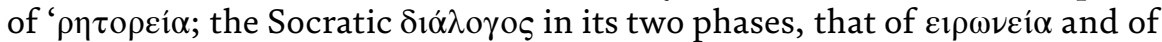

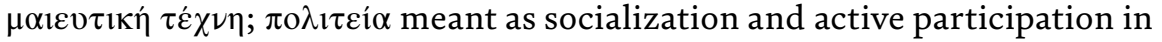
political activities, in the broadest sense of the term; the classical logic with its rules; the $\gamma \nu \varpi \theta l \sigma \varepsilon \alpha v \tau$ ó $\nu$, with its full awareness of everybody's potentialities and limitations; finally the condemnation of 'ó $\beta \rho ı s$. We will, however, go on quoting other expressions full of significance.

This does not diminish the necessity to refer to that long history, as for example with reference to Seneca, Quintilianus, Scholastics or part of it, and other authors in the Middle Age.

When we quote Comenius, we have already arrived at a modern perspective (i.e., at the Modern Age) and not surprisingly in the field of an educational pedagogy practiced in schools, rather than social as it was the art of the Paedagogus in the ancient Greece and Rome.

We claim it should be better to understand deeply the reasons why professionals whose technical-scientific culture is pedagogy based, including the school staff, the historical dimension actually plays a fundamental role, which is not accomplished by other forms of knowledge or by other professions.

\section{Die Sozialpädagogik and its role}

Die Sozialpädagogik is a branch of the General Pedagogy, which, while going back to the mid-nineteenth century, in Italy has been largely ignored for nearly a century and a half, as pedagogy, not a direct and vocational school education, has 
largely been marginalized and as other social scientific knowledge with professional effects such as Psychology and Sociology has long been held in low esteem.

The majority of the academic Italian Pedagogy has long been confined in the 'Magisteri,' particular university faculties that had been founded and developed since the 1930s with primal scholastic educational purposes, and as such, they remained until their closure in the 1990s.

The term "extraschool" and its derivatives have been used for a long time to extend the dominant school education, as if the commitment to education were essentially centered on school, and the rest was attributable to a single generic and vague term. Today, this expression is out of use, but the reductive vision recurs through too many approaches to social pedagogy, which are characterized by a substantial and unique variation to social issues: as if one could forget that the entire pedagogy concerns society, social relationships and the roles of people in society. In simple but strict terms, pedagogy whose domain covers the whole of society is called 'General Pedagogy': this does not make it really necessary to point out or develop a branch called 'Social Pedagogy' with the entire society as its domain as well.

\section{What's new in Italian law?}

In the Italian law and culture, school roles and functions have a strong definition and structure; instead, regulatory definitions and recognitions are missing long time as for other specifically pedagogic professions in the social field.

We had to wait until the end of the year 2017. December 27 2017, the Italian parliament approved in the comprehensive law 205 eight paragraphs of article 1 that finally gave a legal recognition to the pedagogist with a master's degree, as well as to the socio-pedagogical professional educator (3-year degree).

The pedagogist, at the apical level, should have received, after an initial MSc degree, further training with vocational qualification. On the contrary, the professional educator socio-sanitary, that is the operator of educational practice in the world of Health, and acts properly at an intermediate level, in Italy has a proper corresponding initial university education (a 3-year course) and a strong legalized legislation only in healthcare (after the Ministerial Decree 520/98), and follows degree programs that are still active in the faculty of Medicine and Surgery.

Nowadays, one of the pivotal tasks of pedagogy is to bring the Social Pedagogy back to its origins and to its specific nature, taking into account today's emerging needs for social and higher intellectual pedagogy professionbased and for the academic induction-oriented courses. On this task and on its fulfilling, the role of pedagogy is basically played within the culture and society in progress.

\section{The pedagogist's professional practice 'in between'}

A mistake to avoid carefully in the profession of pedagogists is falling in the dualism between theory and praxis. It is a sort of dualism spread in the nineteenth century or before, typically philosophical, belonging to those that John Dewey systematically fought against. Pedagogy cannot be reduced only to a theoretical level or just to the level of praxis, or to some contrasts between them. It is rather a dimension in between theory and practice, synthesis and chance of communication between the two levels mutually irreducible.

The level in between can be defined with the term applicativity. The terminological issue has a very important strength if we consider the persistence of phrases 
belonging to philosophy in the pedagogical debate with their unsuitable content that produces misunderstanding, such as that of 'practical science,' which is still referred not infrequently to pedagogy. The theory-practice sort of dualism was born and raised in philosophy: we do not argue here of its values in that context or of its limits in a broad sense; we simply mean to point out how it is clearly inadequate when applied to pedagogy.

If we remain on the level of theory, we can place in it a number of other scholars and proponents even in a different professional position. We think, for example, of those large companies' managers who plan the main lines of professional training, recruitment, internal relations, or cultural image of the company, its history, its archives, or also the human resources management. Other examples of professional on the theorical plane of Pedagogy can be public Managers (in ministries, local government, health, etc.) who fulfill some actual pedagogical or direction guideline functions on a well-established political plan, or those in large agencies who are in charge for training (in the broadest sense), from whose theories, educational actions are performed; or intellectuals whose creativity directly influences education, or of those who address educational issues from a more general perspective.

At the level of theory, in short, extensive types of subjects can be placed: those who, shall we say, work to develop general views of education that are likely to have a not sudden impact on the educational act.

Nevertheless, it is equally important to grasp the existence of a praxical level with some efforts. The term 'educator' means, even in everyday language, anyone who educates or teaches, that is, any person acting on this level. In this regard, despite the general and specific cultural background, the projects, and even the will of the act, we could say that we are all "educators" for the fact that we are human beings, that is, a place of values, social subjects, knots of a network of interpersonal relationships.

At this level, we can place those who, among the action-oriented ones, practice professionally their function with awareness, according to a plan (not necessarily drawn by themselves) and with some cultural foundation inside a work or planned performance or somehow structured. In this case, it is feasible to apply some adjective or periphrastic qualification to the noun, till to talk of educational operators: in Italy, we saw, the term 'professional educator' pointed out a professional who deals with health, and now many things can change, with the reform processes recently started. It is a sort of a diverse and consistent world: the world of different types of performers: from the private teachers to tutors, governors, community or boarding school assistants and keepers, Betreuer, (jugend)lehrer, prefects, and so forth. As a general rule, they are people who exercise their educational activity with a large predominance (if not exclusive) of the practice level.

But the profession of the pedagogist in action, unlike the ones in the quoted examples, lacks a general framework as for the induction training, although he started having his first legal recognition and status in Italy 2 years ago.

It is useful to draw a fundamental distinction between the general and generic acting in the field of education or 'Erziehung, and a practical action based on a well-defined theoretical and general reference, after having set a plan based on the awareness of the whole. This second articulation of educational professionalism requires a qualification that is not guaranteed either by the current high schools and institutes or by the Socio-Psycho-Pedagogical secondary school curriculum reformed in 2010, which in fact does not have any of the vocational values that are now non-existent also in other types of pre-university schools. For this reason, it seems good a qualification as a university degree, exactly as it is for other technical professions, which in the past decades relied on an education course ending with a high school diploma, and as happened for primary school teachers having a specific degree since 1999. 


\section{More thoroughly about Erziehung and Pädagogik: education and pedagogy}

One of the basic problems of current practices in education is made up of different types of action that do not actually appear to be inscribed in a theoretical framework and a well-set planning of reference, nor do they seem to be carried out by suitably qualified practitioners: this order of problems is also complicated in the compliance with the principles that still recall the Italian Neoidealism, and its refusal to consider the educational dimension scientifically and technically as, well as, teaching itself. In other words, a transition from Erziehung to Pädagogik, and from the Erzieher to Pädagoge, is necessary for all that part, which is fundamental and appropriate to fulfill, that is for an increasingly significant and growing aspect of the educational reality.

Considerations like these would be sufficient to throw light on the existence and importance of the vital intermediate level of pedagogy or, better, the human mediation of the pedagogist.

It would be enough to reflect on the distance between theory and practice as for the specific part of education, leaving no room for illusions (above all the ones groundless in principle) according to which this space is filled by itself, or for educators' voluntary pursuit to theory, or for the theoretical pedagogists' voluntary access to practice.

Short in-service qualification courses also held in agreement with the university serve to cover up an existing problem of an illusory smokescreen and to allow promotions without real consideration for the skilled personnel who will remain qualified only on paper, besides the perpetuation of a neglect educational policy of social and health institutions.

We always remember that an essential characteristic of the Italian school and university is the full legal value of the qualification, the centrality of the conquest of the "piece or sheet of paper," which is at the same time strength, weakness and problematic.

Pedagogy is not limited to the confined dualism theory-practice but is qualified in its own autonomy with the presence of a dimension in between, with an intermediate level, which allows communication and mutual integration of theory and practice for achieving something else significantly different. The Italian Pedagogy today has a wide awareness of this as well as the dangers of reductionism in a way or another [11].

Hence the Professional Pedagogists' own dimension appears, precisely the dimension of Empirie or Anwendungsmöglichkeit. Far from being the Hegelian 'synthesis,' it is the level of the dialectic continuous interaction between theory and practice that admits the usage of the Frankfurt School critical theories, in order to be understood. A few years of an intense debate on the qualification of the Professional Pedagogist took place in the world of trade associations.

At present, there is a general agreement in claiming that it corresponds to the post-graduate level, with a few more years of study, training, development, and one or more passages. However, the 3-year course graduate student in the field of the Sciences of Education is not properly a 'pedagogist,' as a law degree student is not a 'lawyer.' The remembered Italian law 205/2017 finally recognized the profession, asking for at least 5 years of university study.

\section{From Pedagogy as social science to pedagogist as professional practice in society: so that it is democracy and not authoritarianism}

The following pages of this paper will be addressed to take some general guidelines and methodologies into consideration in the practice of the Professional Pedagogy, as well as how it is actually experienced. 
But first, one more reflection is necessary, with regard to the relationship between the level of the general theory, and that of praxis-practice and performance, in education.

An attempt to abolish the level of pedagogical mediation is not impossible: rather, it is unacceptable, not acceptable as it integrates a totalitarian, fundamentalist, humanly incongruous project. A project where there are, on the one hand, a small circle of advisers to the Prince dictating from above the lines of what ends to be a Kommandierte Pädagogik (Commanded Pedagogy), and on the other hand, an army of performers who respond directly to 'the central authority' and that, without a true expertise but full of honors and formal observance, ensure the accurate and loyal implementation of those provisions.

It is not a coincidence that the Pedagogy is absent in similar domains, replaced by philosophy at the top and by practical experience at the bottom.

The denial of pedagogy is well combined with the denial of democracy, with the denial of science, the reduction of scientific culture to pure technology, with the denial of professionalism. Giovanni Gentile was not the unique philosopher teacher in this sense: the problem still occurs over and over again, even today, in various forms.

\section{The Professional Pedagogist's helping relationship: some basic elements of this professional practice}

Pedagogy as a profession, not performed in schools, is a recent one, though grafted on the trunk of an ancient knowledge. For this, it needs doctrinal elements, its own methodology, a specialistic vocabulary, a set of procedures, and so on, elements for a long time held by other professionals, and all consistent with its origin and history, therefore its roots. We will explore below a broadly representative number of them, both as a 'state of the art,' and as suggestions, or as an openness to future experience and developments, referring to the details of some other works where there is no time, nor space to enter [12].

The Professional Pedagogist's helping relationship (initially 'rélation d'aide') is a form of dialogical action, a 'let us talk!'. This is a reason why it can be exchanged, at first glance, with an overlap to certain psychological and psychotherapic interventions, but it is a very different thing, as we are trying to describe.

The pedagogist has no patients or customers, and she/he has interlocutors.

The pedagogist's interlocution is one whose domain is in the educational and relational field and it always takes place on the cultural level, referring to the essential dimensions of man as a subject of culture, history, and cultural evolution. The following are some important examples of fundamental components of this form of professional dialogue:

- The life project

- The relation with peers

- The logical and methodological consistency

- The process of evolution and transformation

- The education process-centered activity

It is an explicit dialog, through which the pedagogist clearly puts her/his thesis and positions into discussion, as the other self is requested to do: each one is called 
to present and treat one's own point of view for what it is, that is, as personal positions that are not meant to be generalized. The pedagogist's interlocution is not effective if someone claims to present her/his own positions like the ones "belonging to everyone", and to be passed for indisputable.

In the dialog, each of the two (or more) parties, including the pedagogist, brings into play what we might call their visions (views, beliefs, etc.). The term, however, indicates at least two different concepts, for which we may suggest, as technical terms, two German nouns.

A first concept consists of the / die Einsichten, those 'visions' that are presupposed to experience and whose possession allows the experience to take place. These are not empirical, but prior to the empirical moment, since most of the positivistic 'pure experience' misunderstanding is scanty reproducible. These conceptual tools are self-evident and unmistakable, but together necessary for the educational process: “Unter Einsichten werden Aussagen verstanden, die det Urteilsart der apriorischen Sätzen entsprechen. Dieses Vorausgehen gilt natürlich nicht im Sinn der physikalischen Zeit, sondern als logisches Vorausgehen" (Insights are statements that correspond to the type of judgment of the a priori sentences. This precedence is of course not in the sense of physical time, but as a logical precedence.) [13]. It is neither the psychological-cognitive insight, that is to say, the sudden enlightenment that helps to solve a problem posed rationally, perceiving the essential relationships, nor the psychoanalytic insight that is the ability to look within oneself, motivations, dynamics, inner meanings. If anything, in this respect, the concept of archetypes can be borrowed from psychoanalysis as an important example.

The Einsichten with a further example, the images of male and female that have so strongly imbued with their own culture the past two or three centuries: the male as an external projection, fast, tending to the sudden attainment of the outcome on the other's ground, even with her sacrifice; the female as an internal projection, all inclusive, tending to achieve some outcomes in the long run, on her own ground and with her own sacrifice. These visions have a metaphor in the physiology of the reproductive organs and, in this sense, they are prior to the experience, but they have nothing to do with the actual males and females as subjects of culture, except for a purposeful education in this sense.

Different concepts, referring to what we would call 'visions,' are the general views of reality under study and, in this case, of the pedagogical interlocution. Those are called die Anschauungen. One thinks of the Welt-anschauungen (worldviews and theories?), probably the best known and most widely used compound term than those that can be formed with this term, but it means more specifically philosophical or ideological views of the universe. We are rather interested in the visions of mankind, of the human being, of the intrinsic characteristics of man as such, that is possible to emphasize by a compound: Mensch-heit-anschauungen.

Typical is the example, in relationships, of the comparison between different Anschauungen of one of the partners who leads a life of external commitment in work, culture, art, sports, and so on, and the other one who expresses her commitment inside the house, in the stability of the relationship and in children: this diversity had its canonical composition in the nuclear couple with a hard, indisputable, division of tasks imposed by an education that is aimed at this, which passed it as if it were 'natural.' Today, other possible solutions are to be found, and this is a goal whose nature is typically professional-pedagogical.

The Anschauungen, with a substantial difference from the previous ones, are also the result of experience and indeed continually subject to revision in the light of the experience itself and evolvable as any other human activity.

What matters most in this dialogic context, of the one and the other "visions," is that each of the parties (including the pedagogist) tells her/his own, thus becoming 
the object of interlocution as well as the necessary conditions for it. Rather, the necessary conditions are the explicit and unreserved complete statement of the one and the other visions, and a willingness to challenge them fully and without reserve.

The latter requirement is an important prerequisite for interlocution, as for any proper educational intervention.

In fact, for an interlocution to be turned on, it must assume a peculiarity in the parties, which we call openness, that is, the full and unreserved availability to change, to become, and to be subject to an evolutionary becoming, to put in question one's own ideas and life project, to reflect on and change one's own choices, especially the fundamental ones, and even things considered taken for granted and well set, including oneself, to begin with one's own person, and a profound conviction of the value of pluralism and divergence.

In front of an interlocutor who refuses somehow to be opened to relevant parts of the dialog, the pedagogist, by rule, could do nothing, in practice, something can be done by indirect means and ways, or looking for glimpses of revelation if it seems that they do not exist.

Dialog, of course, is always bi-directional or multi-directional when the human beings who seek the pedagogist's help are more than one, or when she/ he considers involving other people, and she/he succeeds. But a part of this word process is the pedagogist himself/herself, who must be the first to show openness, and to be the witness of human positiveness. Ideas are always for the man, and we mean all the ideas since Pedagogy could not accept the reverse nowadays.

A project of life is always present, in any person. Of course, it should not be rigidly unchanging, and many difficulties arise precisely when the subject is closed in it, and chained to it, regardless of both its internal (e.g., logic) and external (e.g., disproven by the facts) contradictions. This is not a plan or a model.

In addition, there are often embedded or hidden aspects, which as such do not indicate any contradiction with the reality or with the life plans of other closer persons, even when such contradiction is apparent. A typical case is when implied, tacit, taken for granted aspects in one's life project occur as a desire for obligations or functions to be fulfilled by the partner but never argued or quarreled upon.

Consistency, or at least the compatibility between life projects of those who establish whatever human partnership, should be considered a necessary condition: it is true for the couple, the family, school, education, associations, cooperation, and so forth.

The pedagogist has an important role in clarifying what is implicit, that is, to change the functions and properties (the "extensions") of a sort of hidden file. Note carefully that these are ideas that dwell in the conscious level: digging into the unconscious is not the pedagogist's task, but of the psychologist's task in some of his specialties.

The addressee of the pedagogical support is, therefore, the human subject, meant as a subject of history and culture, as the place of values and a complex interpersonal communication link, as a subject of politics in the broadest sense and in the original sense of $\pi$ o $\lambda \imath \tau \varepsilon i \alpha$ : that is to say, with a strictly technical term, the persona (person). The Latin term entered the philosophy and disciplines of man in the last century. It has had greater success in the context of the Catholic philosophy and pedagogy, but it has been for a long time gotten the attention of laity pedagogists, and moreover, Mounier himself identified its roots in Socrates, Kant, Leibniz, and Pascal.

The term "individual" is employed in other contexts: the use of this term is not incorrect, by itself, when one wants to speak about an element of a population, giving prior attention to the population itself, may be in the case of evolutionary studies, or statistical-operational studies such as those that belong to the so-called (in Italy) experimental pedagogy. But the pedagogist in his professional practice 
focuses his attention on the interlocutor. As Mounier wrote in a famous quotation, Personalism emphasizes "l'insertion collective et cosmique de la personne" [14] (the collective and cosmic insertion of the person).

The attention is required, then, especially when we talk about 'help' (or 'aid?), for example, to 'family, 'school,' 'a company,' 'the association,' 'the sporting club,' and 'the couple.' This is, therefore, a synecdoche: the whole instead of and for its parts. When a pedagogist is invested with a supportive task with reference 'to the couple,' he actually helps the partners to deal with problems related to their being a couple, to their relationship as a couple.

Here, too, the discussion is far from being purely nominalist. For example, choosing one of the frequent cases of which we have extensive experience: when a couple supportive relationship is started, it is not the same thing if the pedagogist helps the one or the other partner, and this even when they both ask for the pedagogist's help and at the same time, as well as the case of parenthood is very different when one is called upon to help parents (or one parent) or the son. The two partners are not characterized by the same "insertion collective et cosmique," and the same goes from parents to children. Problematic situations, in such cases, may also be the same, and sometimes it is not even said that they are such, but this is not true for problems, that is, how each person poses problems starting from problematic situations that can also be similar, but in any case, the similarity cannot be considered for the particular helping relationship to be activated.

A misunderstanding to avoid with careful attention concerns the cultural character of the pedagogical interlocution however it is meant. The pedagogist's intervention is never a therapy, and the pedagogist should not be confused in any way with a therapist. In pedagogy, there is not a 'physiology' that, in violation of some of its standard parameters, integrates some form of disease whose cure is the task of the physician, psychotherapist or some other professional or practitioners.

What the pedagogist can do is, if anything, to be of some help to the therapy that, as just noted, is a support to the therapist himself, or to those who have to approach the treatment or must follow it (but it is not possible to speak of "patient" even in this case), or even for those who are near, as caregivers to the one who must follow a therapy. Typical are the cases of the depressed (or her/his family members) who need a cultural intervention to rationally approach what should be considered a disease like any other and family members affected by a conversion syndrome (formerly 'hysteria') who need to know how to behave during accesses and at the end of these, how to come back to everyday life and every form of relationship after operations or disabling diseases, how to prevent cases of potentially pathological situations to be held under control (such as diabetes), or diseases that require special diets and regimes of life), and so forth.

These are cases in which the pedagogist acts largely as a teacher (the so-called non-school teaching...): cases in which she/he is more likely to appear as a woman/ man of learning and culture, far from the stereotype of the therapist, even though she/he acts in healthcare facilities or at the side of it.

For this reason, she/he cannot call patients her/his interlocutors.

He can instead use the adjective 'clinical,' in the methodological sense. When using this adjective, and the corresponding noun one may note also a distant kind of

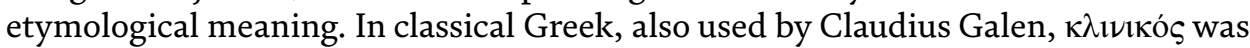
an adjective [15] related to the intervention on the bed ( $\kappa \lambda i v \varepsilon)$ where the patient was lying, that is to say, a specific intervention 'in situation.' One can also refer to the verb $\kappa \lambda i v \omega$, which indicates to address, to lean to approach.

Clinical as a conceptual method is used for the obvious occurrences in the educational dialog as for any elements of communication in the sanitary clinical field: for example, realism, attention to the addressee, the problematic nature of things and situations, the direct relationality, professionalism, the focus on doctrine, the 
possibility of considering any form of individual variation, the mutual exclusion of 'medium, types that instead are involved in the educational processes, even, statistics based. The procedure recalls rather the abduction or retroduction, originally ' $\alpha \pi \alpha \gamma \omega \gamma \eta$ : from some elements of a peculiar 'clinical' case, the expert professional is able to go back to the general case, or 'casuistry.' Human mediation is a condition of knowledge and of professional handling of the case itself. It's a way to remember the anthropological principle; reality is cognizable because of man.

Argumentations such as these lead us to state that the pedagogist should be considered also, and in an increasingly strong perspective, a methodologist.

Among the professional techniques specifically pedagogical, there is the usual procedure, theoretically and epistemologically founded, that is to help the other person to make the transition from the problematic situation to the problem.

With some substantial difference from both the Pragmatistic-Strumentalistic Pedagogy, and the Epistemology of Critical Rationalism or Falsificationism, we call problematic situations any case in which the living-man is in conflict, contrast, contradiction and imbalance, discrepancy, thus in crisis with its environmental interaction; being aware that interaction is undeniable and criticism is usual, normal, obvious, extremely frequent. Only when there is a part of the human disposition to react positively, constructively, ready to take charge of, we properly speak of problem.

We also do not speak of 'solution' to the problem, but 'attempts (note the plural) to solve the problems,' having no criteria of truth.

Problematic situations are into the reality of things, and only the man is able to put them as problems, and to take them in charge, sometimes in such a small way. This is an aspect of vision, properly anthropological of education and pedagogy (General and Professional).

The Professional Pedagogist, for her/his intrinsic reasons, is the one who helps the interlocutor in his/her solution attempts. Even if she/he had possible hypotheses to solve some problems, if anything, she/he should present them as her/his own, or not presenting them at all. The whole dialog-based work consists of ensuring that the other person tries to develop her/his possible solutions.

The pedagogist has no solutions to offer, but an ongoing process that tends to help the research for such solutions. The interlocutor who asked "So doctor, what is the course of study my son can follow?" ; "Must I abandon my wife/my husband?”; and "Must I change my job or stay where I am?", the only answer the pedagogist can give is, ultimately, "we will go on talking about it."

Of course, she/he could envisage her/his possible solution, or even more than one: if it is clear that these are some possible hypotheses and provided that it is one or more within a broader and more diversified variety. But she/he must carefully refrain from doing so, whenever her/his hypotheses are likely to be taken for what they are not (a judgment, diagnosis, expertise, etc.), or it might become an excuse for the interlocutor who hides behind it and breaks the discussion (“the expert told me so!”...).

As for the pedagogist: a researcher, with no ends or $\tau \dot{\varepsilon} \lambda$ os, there is neither a 'physiology' to refer to nor a 'law' the violation of which constitutes an offense, which would lead to judgment and condemnation.

Also, for this, the pedagogist does not make judgments (as pedagogist), and in any case does not impose sanctions, or pronounce convictions. In some cases, he takes on external factors: the diagnosis of a doctor, a judgment of a court, the recognition of habits and established practices of a sociologist...external' does not mean stranger, being well known that the pedagogist's culture is a very complex one, and that she/he must be able to make herself/himself a specific resource of contributions coming from that set of sciences that are presented as Sciences of Education.

The pedagogist rather expresses opinions, and points of view: his own or those of others, always explicitly and admittedly. 
Pedagogist never prescribes, rather indicates.

He does not really give advice, rather suggestions. He does not tell anyone to follow a different path from the chosen one: if anything, he tells that in addition to the determined one there are other tracks and discusses with her/his interlocutor what they are.

After having, presented and argued his views, opinions, points of view, visions (in the sense of Anschauungen and Einsichten), directions, suggestions and anything similar, the next step consists of "let's talk again," provided that the interlocutor maintains the necessary openness.

The answers that the pedagogist can give, and it is her/his duty to give, are answers on method and not on merit. When he gives answers on merit, and it happens, he does not give them as a pedagogist, rather, as a human person to whom the claim by Terentius "Homo sum: nihil humani a me alienum puto" [16] is relevant.

In regard to the interlocutor's legitimate and understandable need to find answers on merit, the pedagogist can only have a specific task: to help him find them.

They are answers, methodologically speaking, which take the form of hypothetical imperatives. The normativity of pedagogy, in the case of Professional Pedagogy (or at least in this case), is a normativity that connects certain directions to the existence of certain premises. The type of response by which the Professional Pedagogist helps his interlocutor to arrive at is a sort of "if...then...."

But still, the hypothetical procedure is, at a closer look, double. It hypothesized the subsistence of the premise or protasis ("if...then...” or "if not...then..."). But the link between the premise and the consequence, protasis and apodosis, "if...then maybe...or if not...then maybe..." is even hypothetical.

Those of the pedagogist, and probably not only belonging to the Professional Pedagogist, are then double hypothetical imperatives: when one cannot read them in this form, which often happens in the educational literature, it comes from the fact that the premise or protasis or the hypothetical link one wishes necessary and rigid, is hidden, with a determinism that is typically positivistic.

This is a way to overcome the dualism, typical of philosophy and intrinsic to it, between prescriptiveness and descriptiveness, between normative and descriptive sciences, nomothetic and idiographic disciplines.

The hypothetical nature of these essential steps in the pedagogical supportive relationship and the overcoming of the just mentioned dualism give substance and implementation also in the pedagogical field to the praise of a systematic doubt that was well taken, in the contemporary epistemology, by the Critical Rationalism.

Doubt permeates the pedagogist's opinions, information, suggestions, visions: expressing himself in these terms and in her/him subsequent professional practice, she/he also gives an account of non-omnipotence of education, being also an example of a way of life, dealing with problems, in strictly pedagogical terms, as well as in coherence with human nature.

An essential part of the pedagogist's technique in the helping relationship is the ability to become involved deeply and basically in the dialog: the pedagogist does not have, at present, either the "clinical detachment" or something that resembles it, and probably he cannot own anything analogous for intrinsic reasons to his specificity.

What he makes systematic use has a lot to do with empathy, such as how it has been dealt with by Carl Rogers. The latest, while rightly pointed out in the History of Pedagogy, was not a pedagogist but a psychotherapist: this should be reminded of those who would claim to transfer to the pedagogical field that Client Centered Therapy, which was named as such (therefore, as previously said, an intervention maybe important but not pedagogical at all) [17].

However, the technique that the pedagogist is required to make use of is substantially different from the pedagogist: $i t$ is to get inside the problematic situation 
suggested by the interlocutor, taking into account deliberately some future developments, in order to give it back in a way that can be solved better by the same interlocutor.

It is therefore suggested to use the original term Einfühlung, which may indicate a design, a technique that one can learn and that is taught and that evokes a different theoretical and professional context (as the same Einsicht instead of Insight). In German, the term Empathie exists as well.

The use of Einfühlung, the absence of any kind of clinical detachment, makes on the one hand the Professional Pedagogist's intervention important, the sense of limit. In this context, some supportive relationships that last months or years, with weekly meetings or even more frequently, as it happens in psychotherapy, or in certain medical or social relations, in sport training, in musical or art teaching, are not to be forecasted.

\section{A kind of conclusion: human imperfection and education}

This, among other things, due to the deepest sense of human limitation characterizes this one as many other educational relationships. Human limitation perceived on the one hand in terms of perfectibility as the other side of imperfection belonging to the same coin, which is mankind, and on the other hand, in its nomothetical and regulatory aspects, that is, the ethics of looking for that "better," which is always possible and that man is oriented to seek and pursue.

The Professional Pedagogist's helping relationship has fairly strict limitations, also for some wear and tear of human resources: approximately, we could talk of a few weeks, or even long-term relationships however made of short and dense interviews and breaks, filled with letters or phone calls or short messages, remembering that the dialog is never exclusive and conclusive in the process.

As it grows and develops, this dialogic relation is meant to be followed by other dialogs, or rather by the next development of that same dialog in other places and with other interlocutors. Even before the supportive relationship begins before meeting the other person, the pedagogist knows very well that the dialog she/ he has to establish will be followed by other interventions, he/she sets how and when, of course, but this basic feature must be clear to her/him and without any prejudice.

There are essentially two basic choices, not mutually exclusive.

One is the observed need to continue the conversation with some other professional or expert: a psychologist, a doctor, a social worker, a lawyer, a sociologist, a therapist, or any other. It is an ethical principle, therefore, on the part of the Professional Pedagogist, not only to ensure an effective redirection that is a plain dimension, which happens at a fixed time but also to supply any help to this (as in the already mentioned so-called support to therapy, for example). This is what we call professional redirection.

The other choice, hopefully, more frequent, consists in propitiating the continuation of the dialogic relation in the context where the problematic situations arose or with people who started the controversies, or with persons that may be involved positively in them. If the dialogue at first, before the professional performance of the Pedagogist, was poor, in the couple, or at work, or in family, or in any human fellowship, it will start again with new and more effective vitality and openness. This is the Professional Pedagogist's act named as canonical redirection.

Anyone can be redirected especially in any site of human relationship, which may have some educational meaning to the interlocutor.

In a time of transition from a short Evo eighteenth/nineteenth century to the next, today's society shows a new need in the field of education, human and social relations. 
The Social and Professional Pedagogy, with its 2500 years of history and the frame of the nineteenth century, Sozialpädagogik has got all the resources to respond in a completely positive way.

\section{Author details}

Franco Blezza

General and Social Pedagogy, PPEQS Department, University “Gabriele

d'Annunzio", Chieti-Pescara, Italy

*Address all correspondence to: franco.blezza@unich.it

\section{IntechOpen}

(C) 2020 The Author(s). Licensee IntechOpen. This chapter is distributed under the terms of the Creative Commons Attribution License (http://creativecommons.org/licenses/ by/3.0), which permits unrestricted use, distribution, and reproduction in any medium, provided the original work is properly cited. (cc) BY 


\section{References}

[1] Kurlansky M. 1968: The Year That Rocked the World. New York, NY: Ballantine Books; 2003

[2] Kuhn TS. The Structure of Scientific Revolutions. Chicago, IL: University of Chicago Press; 1962 (1970 new edition with the Post scriptum)

[3] Lyotard J-F. La Condition Postmoderne. Paris: Les Editions de Minuit; 1979

[4] Durkheim DÉ. Introduction à la sociologie de la famille. Annales de la Faculté des lettres de Bordeaux. 1888;10: 257-281

[5] Durkheim DÉ, La famille conjugale. Revue Philosophique. 1921;90:2-14

[6] Le Play PFG, Euvres de F. Le Play I: Principes de paix sociale: La famille, II: La Réforme de la société: Le travail, dir. Jacques et René Wittmann. Paris: Éditions d'histoire et d'art, Librairie Plon; 1941

[7] The Art of the paedagogus. That, paedagogus was a language mold, deriving from $\pi \alpha 1 \delta \alpha \gamma \omega \gamma o$ s, and that this term on its turn, derived from $\pi \alpha i$ s e ' $\alpha \gamma \omega$, is a different matter. The very strong recognition in the field operated by Luigi Volpicelli in Volume 2 of the Lessico delle scienze dell'educazione (Lexicon of the sciences of education) directed by him (2 vol., Milano, Vallardi, 1978) pp. 807-811, just under "Education", is extremely enlightening in this regard. In the ancient Greek, language of great philosophical and pedagogical vocation, there would be all the lexical resources for this purpose, but no tradition has brought the term $\pi \alpha 1 \delta \alpha \gamma \omega \gamma i \alpha$ designating precisely the art or the office or the task of the $\pi \alpha 1 \delta \alpha \gamma o \gamma$ ó $\varsigma$, or an utterance such as $\pi \alpha 1 \delta \alpha \gamma \omega \gamma ı \kappa \eta ́ ~ \tau \dot{\varepsilon} \chi \nu \eta$, from ancient times through the Middle Ages to the modern Age. Lemma "Pedagogia" by Antonio Mura
[8] Rey A. Le Grand Robert de la Langue Française. Vol. 6 Vol. Paris: Editeur Le Robert; 1953

[9] For instance L'Éducation morale (1902/3), Éducation et sociologie (1922), L'Évolution pédagogique en France (1938). And other works public domain on the Web. They were originally university lecture notes

[10] Dewey J, Democracy and education, New York, MacMillan Co., 1916, chap. XXIV. The title refers to education, not Pedagogy, because the term was not commonly used in the USA in those times. However, let us remember the foundational work My pedagogic creed. School Journal. 1897;54:77-80. Both public domain on the Web

[11] Just consider the majority of the writings of self-presentation by a significant part of academic Pedagogists. In: Borrelli M. (ed.) La Pedagogia italiana contemporanea. 3 vols. Cosenza, Pellegrini; 1995-1996

[12] Some Italian book on the specific subject: Crispiani P, Pedagogia clinicaLa pedagogia sul campo, tra scienza e professione. Azzano San Paolo BG, Junior, 2001. Massa R, La clinica della formazione. Milano, Franco Angeli, 1992. Blezza F, Pedagogia della vita quotidiana. Cosenza, Luigi Pellegrini, Cosenza, 2011. Rezzara A, Dalla scienza pedagogica alla clinica della formazione. Sul pensiero e l'opera di Riccardo Massa, Milano, Franco Angeli, 2004. Crispiani P Giaconi C, Hermes 2016. Glossario pedagogico professionale. Azzano San Paolo BG, (Junior, 2015. Blezza F, Il debito coniugale e altri dialoghi pedagogici, Limena PD, Libreria Universitaria, 2016. Blezza F, Pedagogia professionale Che cos'è, quali strumenti impiega e come si esercita. Limena PD, Libreria Universitaria, 2017. In particular in this last volume there are rich references both classical and current 
[13] Fischer KG. Wie ist

Theoriebildung für Politische

Didaktik Möglich? In: Borrelli M, editor. Deutsche Gegenwartspädagogik Band I. Baltmannsweiler: Schneider; 1993. p. 107

[14] Note added à:Lalande A, editor. Vocabulaire Technique et Critique de la Philosophie. Paris: Presses Universitaires de France; 1926

[15] "Clinical" today can be matched with ' $\grave{\eta} \kappa \lambda \iota \nu \chi \chi$ ' $\tau \dot{\varepsilon} \chi \nu \varepsilon$, that is roughly 'clinical art'. Moreover, is increasing the use of the Anglo-American term 'clinic', to indicate, for example, a training and educative session in sport or music with an athlete, an artist, an example of particular value, in which the great personage of that human activity enters in the context of a team or a complex or a band or other human society, to bring his own and very important and useful example. This is an exceptionally effective way of proceeding as education and Bildung, which generally requires limited time and efforts. As usual, the technical terms should not be translated. See References in the [12] note

[16] Heautontimorumenos (163 a. C. n.) (the punisher of himself, a Greek word in Latin) by Publius Terentius Afro (190 or $185-159$ a. C. n.) v. 77. The full text is publicly available online

[17] Rogers C. Client Centered Therapy. Boston: Houghton Mifflin Co.; 1951 


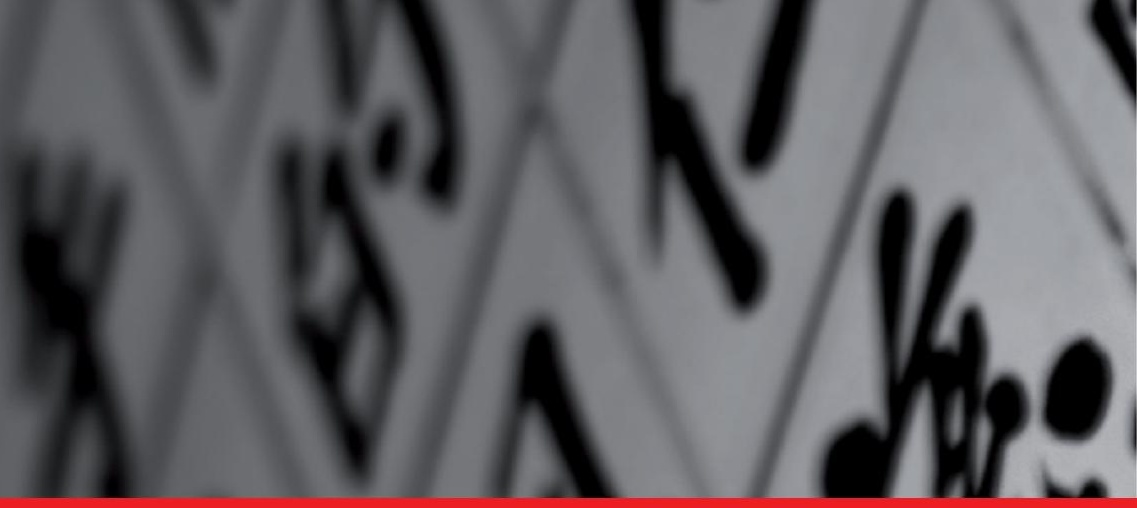

\section{Edited by Gilson Porto Jr.}

This book, "Education Systems Around the World", is a collection of reviewed and relevant research chapters that offer a comprehensive overview of recent developments in the field of social sciences and humanities. The book comprises single chapters authored by various researchers and edited by an expert active in the field of social studies and humanities. All chapters are unique but are united under a common research study topic. This publication aims to provide a thorough overview of the latest research efforts by international authors on social studies and humanities, and open new possible research paths for further novel developments.

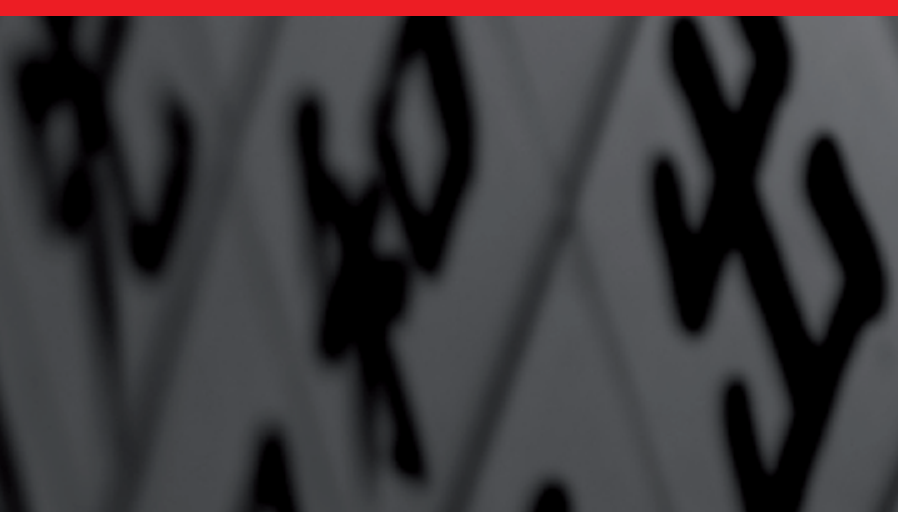

